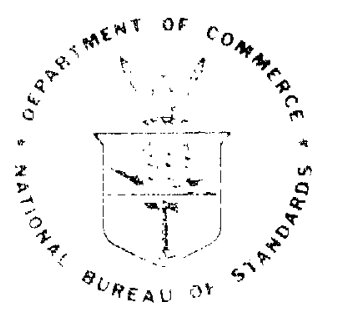

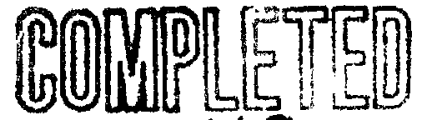 \\ NBS TECHINICAL NOTE 1045
}

U.S. DEPARTMENT OF COMMERCE / National Bureau of Standards

4

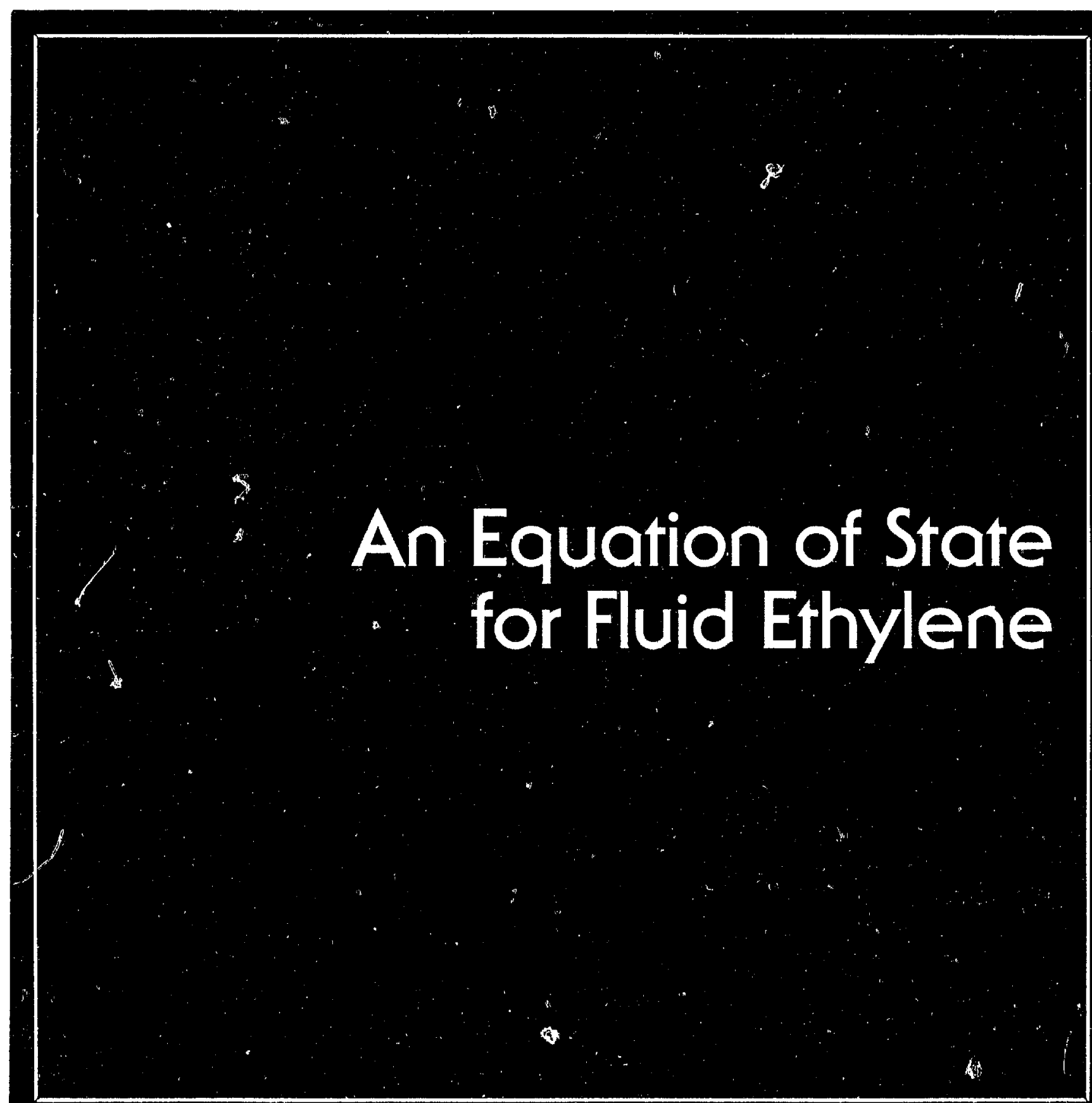




\section{NATIONAL BUREAU OF STANDARDS}

The National Bureatu of Standards wats estiablished by an act of Congress on March 3, 1901. The Bureatus overall goal is 10 strengthen and advance the Nation's science and technology and tacilitate their effective application for public benetit. To this end. the Bureau conducts research and provides: (1) a hasis for the Nation's physical meatsurement system, (2) scientitio and echnological services for industry and gorerument. (3) a technicall hasis for equaty in tride, and (4) technicil sersices to promote nuhls: siltely. The Bureaus techncal work is performed by the National Measurememt Laboratory the National Enginering Laboratory, and the Institute for Computer Sciences and Techno,ugy.

IHE. NATIONAL MEASUREMENT LABORATORY provides the national system of physical and chemical and materialis measurement; coordinates the system with measurement systems of other nations and furnishes essential services leading to accurate and unilorm physical and chemical measurement throughout the Natiois's scientilic community, industry. and commarce: conducts materials reseirch leading tw improved methods of measurement. standards. and data on the properties of materials needed by industry. comenerce. educittonal institutions, and Government: provides aldvisury and research services to other Government agencies: develops, produces, and distrihules Standard Reference Materials; and provides ealibration services. The Laboratory consists of the following centers:

Absolute Physical Quantities: - Radiation Research - Thermodynamics and Molecular Science - Analytical Chemistry - Matterials Science.

THE NATIONAL ENGINEERING LABORATORY provides technology and tecanical services to the pubtic and private sectors to address national needs and to solve nusional problems; conducts research in engineering and applied science in support of these elforts: huilds and maintains competence in the necessary disciplines required to carry out this research and technical service: develops engineering data and measurement capabilities: provides engineering measurement traceability services: develops test methods and proposes engineering standards and code changes: develops and proposes new engineering practices: and develops and improves mechanisms to transfer results of its research to the ultimate user. The Laboratnry consists of the following centers:

Appled Mathematics - Electronics and Electrical Engineering - Mechanical Fngineering and Process Technology - Building Technology - Fire Research Consumer Produc1 Technology - Field Methods.

THE INSTITLTE FOR COMPLTER SCIENCES AND TECHNOLOGY conducts research and provides scientutic and technical services to aid federal agencies in the selectonn. acquisition, application, and use of computer iechnology to improve effectiveness and economy in Government operations in accordance with Public Lau 89-306 (40) U.S.C. 759), relesant Executive Orders, and other directives: carries out this misson by managing the rederal Informattion Processing Standards Program, developing iederal ADP standards guidelines, and managing.$t$ ederal participation in ADP voluntary standardiation activities: provides scientific and lechnological advisory services and assistince to Federal agencess and provides the lechnical foundation for computer-related policies of the federal Government. The Institute consists of the lollowing centers:

Programming Science and Technolog: _- Compuler Systems Engineering.

Headquarters and laboratories al Gaithershurg. MI), unless otherwine noted: mailing address Washington. DC 20234.

Some divisunn within the center are located at Boulder. $\mathrm{CO}$ 8(0)301 


\title{
An Equation of State for Fluid Ethylene
}

\author{
R. D. McCarty \\ R. T. Jacobsen
}

Thermophysical Properties Division

National Engineering Laboratory

National Bureau of Standards

Boulder. Colorado 80303

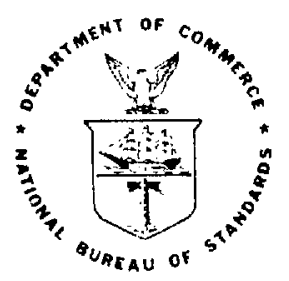

US. DEPARTMENT OF COMMERCE. Malcolin Baldrige. Secreion NATIONAL BUREAU OF STANDARUS Erriest Ambler Chrector 
NATIDNAL BUREAU OF STANDARDS TECHNICAL NOTE 1045

Nar Bur Srand (US) Tech Nore 1045 104 poges (July 1981) CODEN NBTNAE 


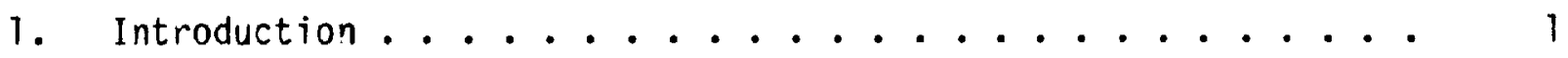

2. Experimental Measurenents of the Thermodynamic Properties of Ethylene ................... . . 4

2.1 Pressure-Density-Temperature Data ......... 4

2.2 Coexistence Properties ............. . . 4

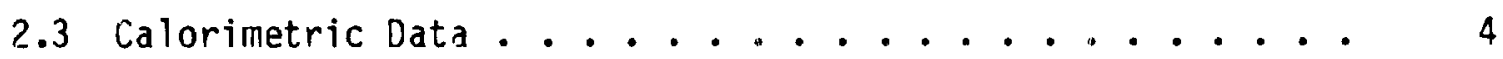

2.4 Velocity of Sound Measurenents .......... 8

2.5 Second Virial Coefficients ........... 8

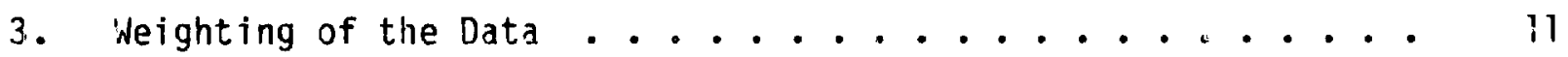

4. The Determination of the Equation of State ........ 11

4.1 Anaiys is of the Functional Form of the Equation of State . 11

4.2 The Selection of Data for Multiproperty Fitting . . . . 12

5. Liquid-Vapor and Liquid-Solid Coexistence ......... 14

5.1 Liquid-Vapor Coexistence .............. 14

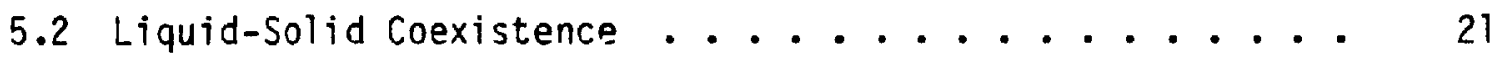

6. The Ideal Gas Heat Capacity Equation .......... ?1

7. Derived Thermodynamic Properties ............ 23

8. Comparisons of the Equation of State to P-p-T Data ...... 26

9. Comparisons of the Equation of State With Related

Thermodynamic Data . . . . . . . . . . . . . 26

10. Estimated Accuracy of the Equation of State ........ 41

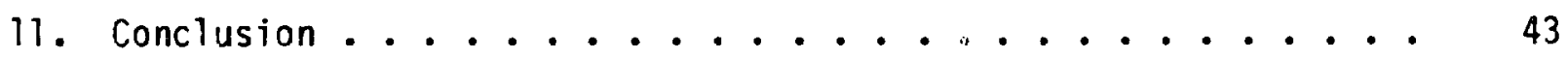

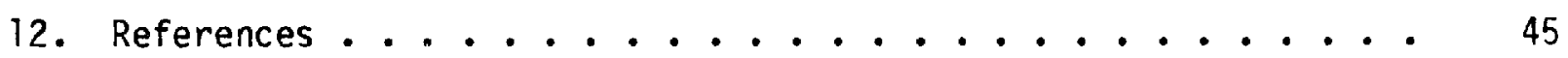

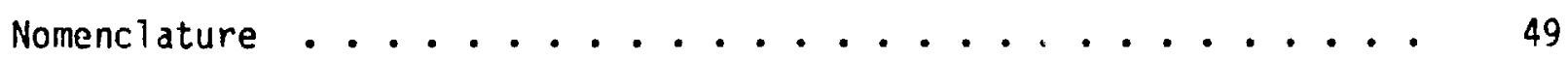

APPENDIX A. Comparisons to Available Data Sets Including Those

Used in the Determination of the Coefficients of the

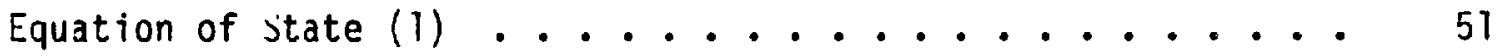

APPENDIX B. Thermodynamic Properties of Fluid Ethylene . . . . . 73

APPENDIX C. Guide for Use of Computer Programs for the Calculation

of Thermodynamic Properties of Ethylene ......... 129 


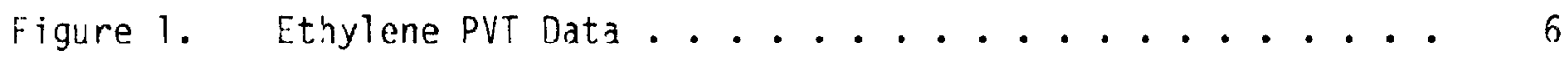

Figure 2. Ethylene ileat Capacity Data........... 7

Figure 3. Ethylene Velocity of Sound Data.......... 9

Figure 4. Ethylene PVT Data Used in the Determination of the

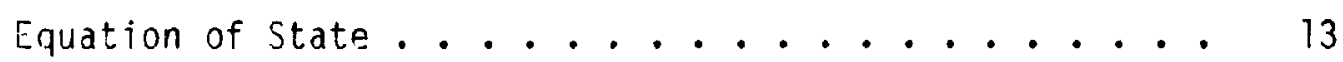

Figure 5. Ethylene Velocity of Sound Data Used in the Determination of the Equation of state ........... 15

Figure 6 . Comparisons of PVT Values of Saturation ....... 18

Figure 7. Comparisons of Ideal Gas Heat Capacity Values . . . . 24

Figure 3 . Deviations of Calculated Values of Density from Selected PVT Data. . . . . . . . . . . 27

Figure 9 . Deviations of Calculated Values of Heat Capacity Froin

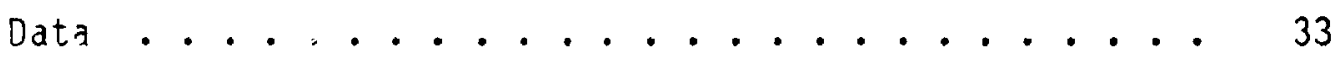

Figure 10. Deviations of Calculated Values of Velocity of Sound From Selected Data .......................... 34

Figure 11. Deviation of Calculated Values of Velocity of Sound From Selected Data for the Saturated Liquid of Gamon [9] . . 36

Figure 12. Comparisons of Calculated Values of $C_{p}$ with Data ... 38

Figure 13. Accuracy of the Equation of state for Assumed Errors in Temperature and Pressure ........... 42

Figure A-1. Comparisons to PVT Data ............ 52

Figure A-2. Comparisons to Velocity of Sound Data........ 58

\section{List of Tables}

Table 1. Summary of P-p-T Data for Exhylene ........ 5

Table 2. Recent Velocity of Sound Measurenents for Ethylene ... 8

Table 3. The Second Virial Coefficient $B(T)$ for Ethylene in the Infinite Series PV/RT $=1+B(T) / V+\ldots 10$

Tabie 4. Coefficients for the Equation of State (1) for Ethylene $~ 16$

Table 5. Sumnary of Vapor Pressure Data for Ethylene . . . . . 17

Table 6. Coefficients for the Vapor Pressure Equation for Ethylene 19

Table 7. Summary of Saturation Density Data Used in This Work . . 19 
Table 8. Coefficients for Approximating Functions for Saturation Densities for Ethylene ............

Table 9. Tabulated Differences Between Saturation Properties Calculated From Equation of State (1) Alone and the Intersection of the vapor Pressure eq (2) With the Equation of State (1) ............ ??

Table 10. Coefficients for the Ideal Gas Heat Capacity Equation

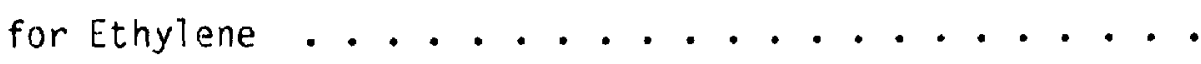

Table 11. Comparison of Calculated and Experimental Data for the Enthalpy of Vaporization ............

Table A-1. Data Points With Deviations Exceeding the Scale of Figure $A-1$............................ 54

Table A-2. Heat Capacity Data Wit'n Deviations Exceeding the Scaies

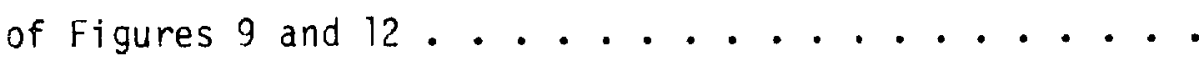

Table A-3. Velocity of Sound Data With Deviations Exceeding the Scale of Figure A-2.............. 71

Table B-1. Thernodynamic Properties of Saturated Ethylene . . . 74

Table B-2. Thermodynamic Properties of Ethylene . . . . . . 83

Table $\mathrm{C}-1$. SUBROUTINE PROPS and Its Entry Points....... 133

Table C-2. Iterative Solutions for Density......... 134

Table C-3. FUNCTION CPI and Its Entry Points ......... 135

Table $\mathrm{C}$-4. Functions for Thermodynamic Properties ...... 136

Table C-5. Subprograns for Coexistence Properties ....... 137 
AN EQUUATION OF STATE FUR FLUID ETHYLENE ${ }^{\top}$

$$
\begin{aligned}
& \text { R. D. McCarty } \\
& \text { and } \\
& \text { R. T. Jacobsen } 2
\end{aligned}
$$

Thermophysical Droperties Division

National Engineering Laboratory

National Bureau of Standards

Boulder, Colorado 80303

A thermodynanic property formulation for ethylene developed as a part of a joint industry-government project, is presented. The formulation includes an equation of state, vapor pressure equation, and equation for the ideal gas heat capacity. The coefficients were determined by a least squares fit of selected experimental data. Comparisons of property values calcuiated usinc the equation of state with measured values are given. The equation of state is not valid in the critical region $\left(\rho_{C} \pm 0.3 \rho_{C}\right.$ for temperatures of $\left.T_{C} \pm 0.05 T_{C}\right)$. Errors on the order of $2 \overrightarrow{0}$ percent for derived properties and 10 percent for density may be encountered near the critical point. Tables of the thermodynamic properties of ethylene for the liquid and vapor phases for temperatures from the freezing line to $450 \mathrm{~K}$ with pressures to $40 \mathrm{MPa}$ are presented. The equation of state and its derivative and integral functions for calculating thermodynamic properties are included. Estimates of the accuracy of calculated properties are given. A guide for use of computer prograins for the calculation of thermodynamic properties of ethylene with listings of subprograms and a sample program to illustrate the use and results of the prograin are included.

Key words: Computer programs; equation of state; ethylene; thermodynamic properties; tabular values.

\section{Introduction}

Six years ago a group of Petrochemical companies and the National Bureau of Standards embarker on a joint industry-government project to deternine the therinodynamic projerties of ethylene. The first four years of the project were devoted to experimental work, which provided data for the development of a

1 This work was a joint Industry-Governinent project under the sponsorship of Celanese Chemical Company, Cities Service 0il Company, Continental 0il Company, Gulf Research and Development, Mobil Chemical Company, Monsanto Polymers and Petrochemicals Company, Phillips Chemical Company, Union Carbide Corp. and the National iureau of Standards.

2 particifated in this project during a temporary assignment with the Thermophysical Properties Division. Permanent affiliation is the Center for Applied Tnermodynamic Studies, Iniversity of Idaho, Moscow, Idaho 83843. 
mathematical model for the thermodynamic properties of ethylene. The fifth and final year of the project was spent developing the model.

Une of two resulting equations of state for ethylene is presented here for the range of liquid and vapor states for temperatures from the triple-point temperature to $450 \mathrm{~K}$, with pressures to $40 \mathrm{MPa}$. The second equation of state is for the critical region and appears elsewhere (Hastings, et al. [14]). With a few exceptions, the equation of state presented here represents the se?ected experimental P-p-T data to within the estimated accuracies of these data. Comparisons to various experimental values of other thermodynamic properties indicate some discrepancies between those experimental data and values calculated using the equation of state. These discrepancies, which are discussed in sections 8 and 9, are particularly evident in the critical region, though some irreconcilable discrepancies are found outside of the critical region. The equation of state given here is not valid in the critical region $\left(\rho_{C} \pm 0.3 \rho_{C}\right.$ for temperatures of $\left.T_{C} \pm 0.05 T_{C}\right)$.

The equation of state may be used for the calculation of accurate tables of chemodynamic properties of ethylene within the range of its applicability. This equation may also be readily adapted to systems analys is work where iterative solutions are required to solve the equation for known variable pairs other than density and temperature. A table of thermodynamic properties of ethylene for the range of applicability of the formulation is included here.

In determining the equation of state for ethylene, considerable experimentation in the use of various least squares methods and different functional forms was conducted. Also, experimentation in the use of different groupings of the independent data sets used in detormining the equation of state led to the selection of several data sots for use in the least squares deternination of the final coefficients.

In addition to the equation of state, the ancillary functions required for the calculation of thermodynamic properties are given. These include a vapor pressure equation, an equation for the ideal gas heat capacity, and equations for the density of the saturited liquid and saturated vapor.

A sumary of the avaijuble data for ethylene is given, and the ranges of these data are tabulated. Comparisons of these measured data to values calculated from tile equat:on of state have been made to establish the accuracy of the equation of state in representing $P-\rho-T$ values and other thermodynamic properties. These comparisons have been divided into twu groups. The first 
group includes those data which were used in the fit and the second group consists of all the data sets that were known to the authors, including those used in the fit. The comparisons to data used in the fit are an indication of the success of the model in representing the data selected for the least squares process, while the comparisons to all data provide information about the relative agreement of data sets from different sources. The latter comparisons are included in Appendix A.

The thermodynamic properties reported here have been calculated using the equation of state and derivative relations among the thermodynamic properties. Since the equation of state has been developed to co:form to the Maxwell criterion for phase equilibrium, properties of the liquid may be calculated by continuous integration of the equation of state through the two-phase (1iquidvapor) region of the surface. The liquid-vapor coexistence properties included in the tables have been calculated using the vapor pressure equation to establish the saturation temperature for each specified pressure.

No estimate of the accuracy of this formulation for the region near the critical point is presented here. Since analytic equations of state must fail at the critical point in the representation of anomalous behavior of certain properties, the user of this work is advised that this formulation should not be used within about 5 percent of the critical temperature and 30 percent of the critical density. The recent work of ilastings, et al. [14] should be used to calculate thermodynamic properties of ethylene within the near-critical region. The formulation of Hastings, et al. [14] includes a scaled fundantental equation using revised and extended scaling techniques that is accurate in the representation of critical region data to within $5 \times 10^{-4} \mathrm{~K}$ in temperature, $5 \times 10^{-5} \mathrm{MPa}$ in pressure, and $U .03$ percent in density. The critical point values of P-p-T used here are taken froin Hastings, et al. [14].

Much of the experimental data used in the development of the equation of state for ethylene has been measured as a part of the joint industry-government ethylene project under the direction of tine National Bureau of Standards, Office of Standard Reference Data. The availability of high quality measurements of the thermodynamic properties of ethylene has provided excellent definition of the surface of state, and has uncovered some problems of scientific interest in the representation of this surface by present modeling techniques. Further studies of the modeling of the surface of state of fluids of engineering interest may 
well make use of the data for ethylene in efforts to improve the representation of data near saturation and in the critical region.

2. Experimental Measurements of the Thermodynamic Properties of Ethylene

2.1 Pressure-Density-Temperature Data

The experimental P-p-T data sets for ethylene are listed in table 1 . The data for the liquid and vapor states of ethylene form a comprehensive retwork of values to represent the surface. The distribution of these data is shown in figure 1. For clarity, this figure includes only 2331 data points from the total of 2706 points listed in table 1 . The data omitted are near the critical point. In instances where there are two or more papers by the same principal author, the symbols used in the data map represent data by that author from more than one reference.

\subsection{Coexistence Properties}

Recent measurements of the vapor pressure of ethylene are reported in Douslin and Harrison [6], Straty [33], Bigeleisen, et al. [3], Egan and Kemp [8], Hastings and Levelt-Sengers [13], Michels and Wassenaar [26], Tickner and Lossing [39], and Gammon [9]. Measurements of the orthobaric densities of ethylene are reported in Hastings, et al. [14], Golovskii and Tsymarnyi [10], Menes, et al. [24], and Haynes [15].

\subsection{Calorimetric Data}

Measurements of the isochoric heat capacity of ethylene for eight isochores have been made by Weber [47]. Nominal densities of these isochores are 4.6,5.9, $6.7,11.8,15.6,17.8,21.6$ and $20.0 \mathrm{~mol} / \mathrm{dm}^{3}$. Values of $C_{v}$ have been derived from velocity of sound measurements by Gammon [9]. Isobaric heat capacity values for ethylene are reported by Vaschenko [42], by Hejmadi and Powers [16], and by Watanabe [45]. The $C_{v}$ data of Weber [47] and Gammon [9] and the $C_{p}$ data of Vaschen:.o [42], Hejmadi and Powers [16], and Watanabe [45] are illustrated in figure 2. Four $C_{p}$ data points of Watanabe [45] and one $C_{p}$ data point of Vaschenko [42] are for pressures below the scale of figure 2 and are not included in the figure. Selected values of the $C_{v}$ data of Weber [47] were included in the data set used for determining the equation of state. However, theso data were used in this work primarily to provide an indication of the reliability of values of $C_{v}$ and $C_{p}$ calculated using the equation of state and the ideal gas heat capacity equation. 
Table 1. Summary of P-p-T Data for Ethylene

\begin{tabular}{|c|c|c|c|}
\hline Source & $\begin{array}{l}\text { Number of } \\
\text { Data Points }\end{array}$ & $\begin{array}{c}\text { Pressure } \\
\text { Range (MPa) }\end{array}$ & $\begin{array}{c}\text { Temperature } \\
\text { Range (K) }\end{array}$ \\
\hline Douslin and Harrison $[6]^{3}$ & $\begin{array}{r}331^{5} \\
296^{6} \\
31^{7}\end{array}$ & $\begin{array}{l}1.4-39.6 \\
1.3-27.6 \\
5 .-24.6\end{array}$ & $\begin{array}{l}248-448 \\
238-284 \\
282-448\end{array}$ \\
\hline Golovskii, et al. [11] & 114 & $1.2-59.8$ & $106-232$ \\
\hline Golorskii, et al. [12] & 162 & $5.7-201.1$ & $199-329$ \\
\hline Hastings and Levelt-Sengers $[14]^{3}$ & ]$^{3} 141$ & $4.7-8.4$ & $279-303$ \\
\hline Lee $[21]$ & 90 & $0.2-81.8$ & $298-348$ \\
\hline Levelt-Sengers [22] & 91 & $0.2-3.5$ & $220-? 73$ \\
\hline Michels, et al. $[27]^{4}$ & 110 & $1.7-27.8$ & $273-423$ \\
\hline Michels and Geldermans [25] $]^{4}$ & 311 & $1.7-308.3$ & $273-423$ \\
\hline Prasad $[30]$ & 145 & $0.2-5.6$ & $298-423$ \\
\hline Saville $[31]$ & 90 & $0.2-4.1$ & $244-293$ \\
\hline Straty $[33]$ & 244 & $0.6-370.5$ & $105-320$ \\
\hline Thomas, et a $1 .[37]$ & 123 & $3.7-25.4$ & $244-354$ \\
\hline Thomas and Zander [36] & 43 & $0.3-3.0$ & $273-323$ \\
\hline Thomas, et a $1 .[38]$ & 87 & $0 . \hat{3}-9.9$ & $253-348$ \\
\hline Trappeniers, et ail. [40] & 675 & $1.6-289.8$ & $273-423$ \\
\hline Voityuk and Labinov [44] & 74 & sat.1iq. -6.0 & $183-273$ \\
\hline
\end{tabular}

3 Data taken as a part of this project.

4 These data have been superseded by those of Trappeniers, et al. [40] and are not used in this work.

5 Data reported on iscchores.

6 Data reported on isotherms.

7 Data for the critical isochore. 


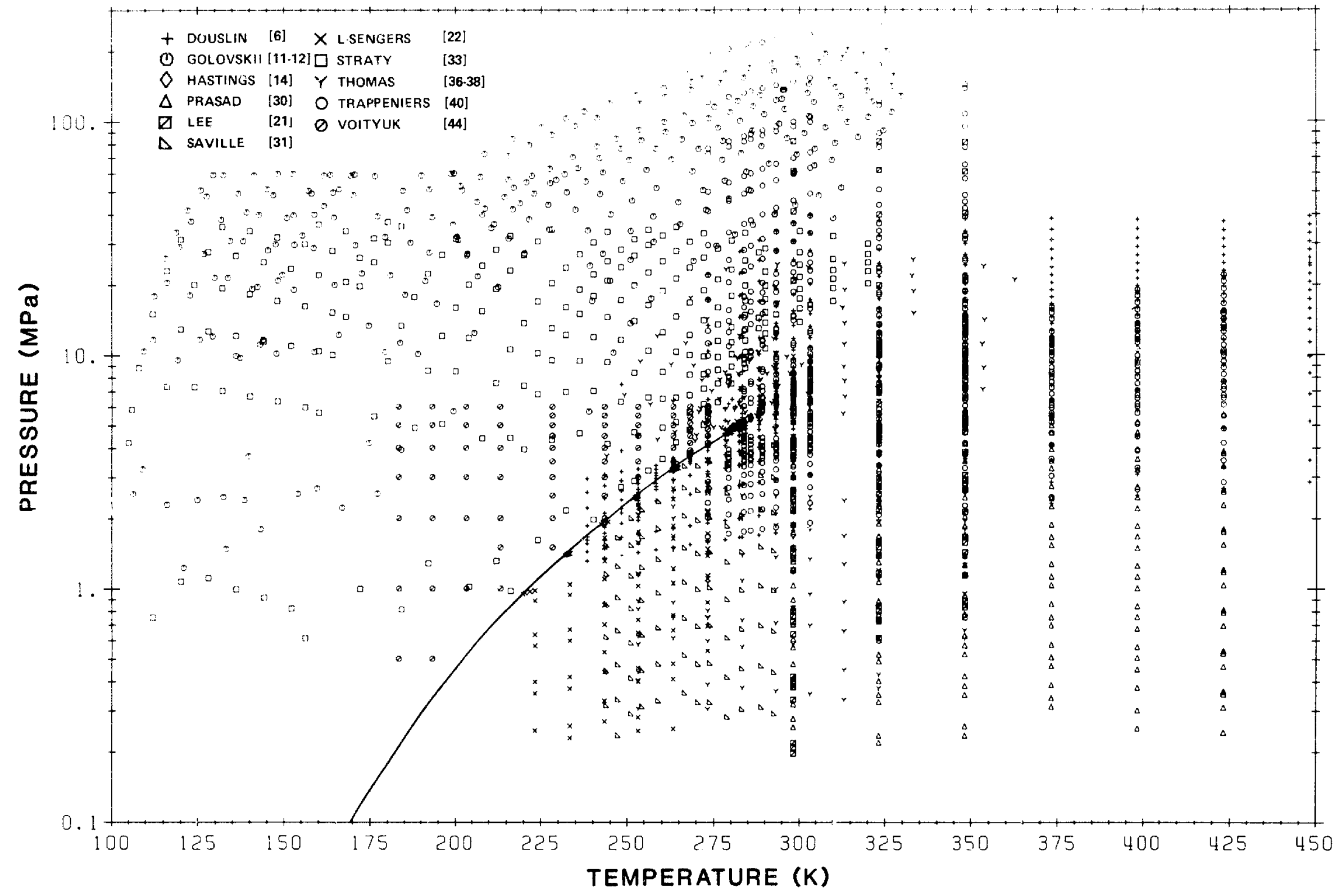

Figure 1. Ethylene PVT Data 


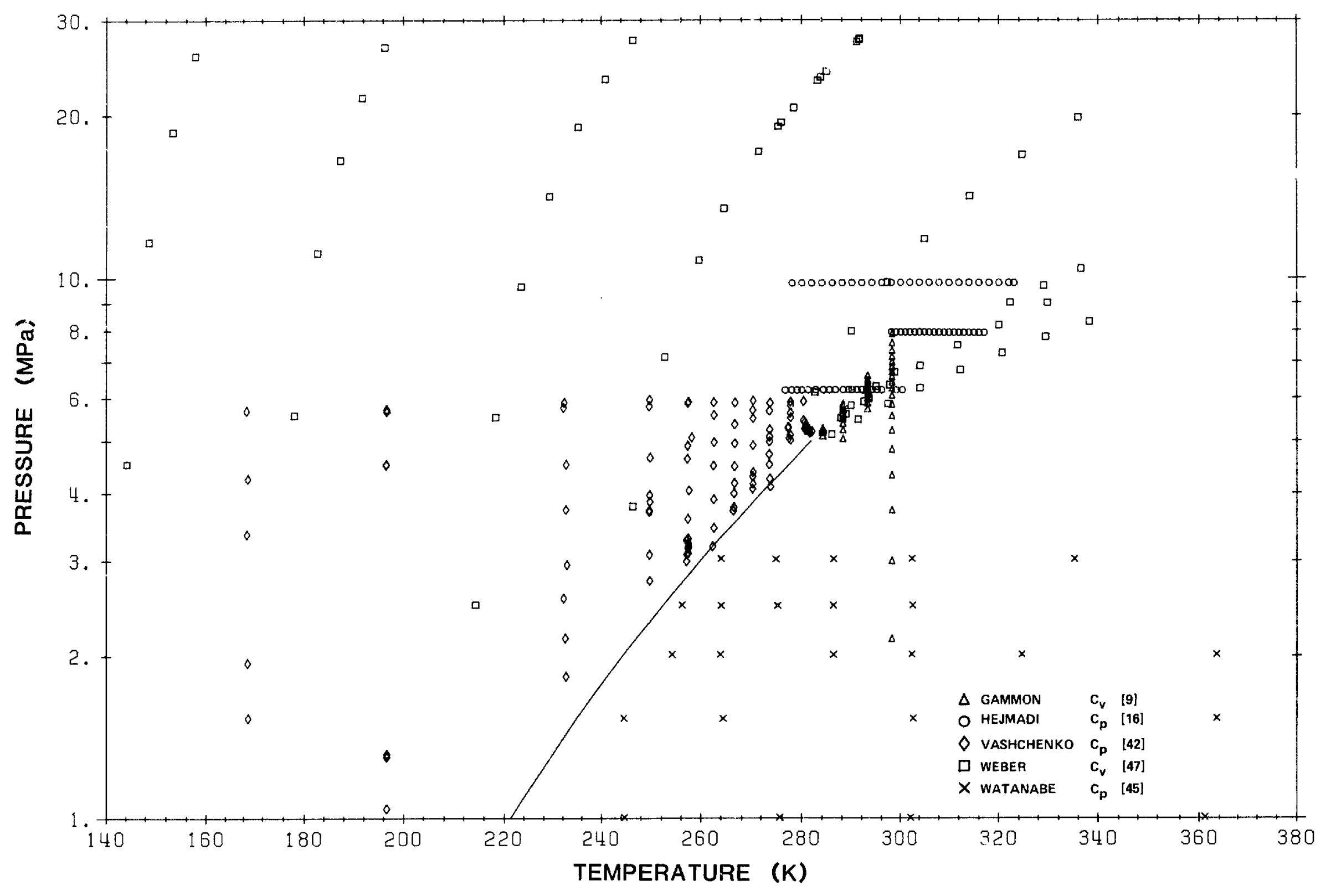

Figure 2. Ethylene Heat Capacity Data 


\subsection{Velocity of Sound Measurements}

The velocity of sound of ethylene has been measured extensively. The 753 data points of Dregulyas and Stavtzev [7], Gammon [9], Soldatenko and Dregulyas [32], Terres, et a]. [35], Meh1 [23], and Herget [17] cover the surface of state as shown in figure 3. Five data points of Gammon [9] on the saturated liquid line are for pressures below the scale of figure 3 and are not shown on the figure. These data were not used in the fitting of the coefficients, except as noted below, but were used to provide confirmation of the accuracy of the resulting equation of state for the calculation of veincity of sound for both liquid and vapor states. Table 2 summarizes the recent velocity of sound data for ethylene.

Table 2. Recent Velocity of Sound Measurements for Ethylene

\begin{tabular}{lcccc}
\hline \multicolumn{1}{c}{ Source } & $\begin{array}{c}\text { Number of } \\
\text { Data Points }\end{array}$ & $\begin{array}{c}\text { Pressure } \\
\text { Range (MPa) }\end{array}$ & $\begin{array}{c}\text { Temperature } \\
\text { Range (K) }\end{array}$ \\
\hline Dregulyas and Stavtzev [7] & 116 & 0.15 & -59.0 & $193-282$ \\
Gammon [9] & $200^{8}$ & $0.0002-7.9$ & $104-298$ \\
Soldatenko and Dregulyas [32] & 262 & $0.03-9.9$ & $193-473$ \\
Terres, et al. [35] & 94 & $0.1-11.8$ & $296-448$ \\
Meh1 [23] & 24 & $0.1-1.0$ & $273-373$ \\
Herget [17] & 57 & $3.6-7.3$ & $282-296$ \\
\hline Data taken as a part of this project. & & & \\
9 Including 28 data points for the saturated liquid. & \\
10 Including 10 data points for the saturated vapor. & \\
\hline
\end{tabular}

\subsection{Second Virial Coefficients}

The second virial coefficient for ethylene is given in a number of the references in section 12. Three of the references, Douslin and Harrison [6], Levelt Sengers and Hastings [22], and Waxman [46] contain second virial coefficients from work which was a part of this project. These values, which are considered to be the best values available, are repeated in table 3 for the 


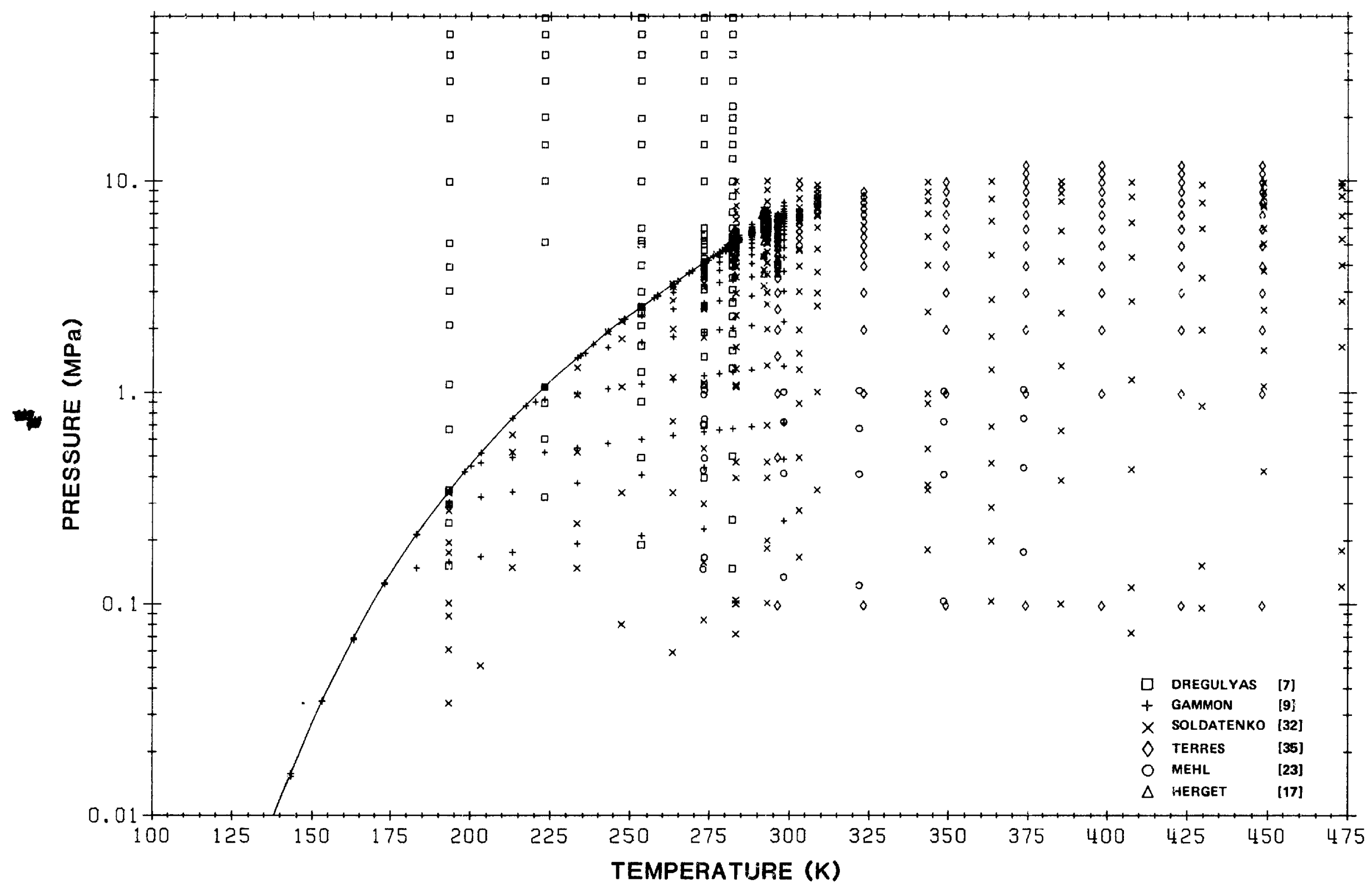

Figure 3. Ethylene Velocity of Sound Data 
Table 3. The Second Virial Coefficient $B(T)$ for Ethylene in the Infinite Series PV/RT $=1+B(T) / V+\ldots$

$$
10^{3} \mathrm{~B}(\mathrm{~T})\left(\mathrm{dm}^{3} / \mathrm{mol}\right)
$$

\begin{tabular}{|c|c|c|c|c|}
\hline$T(K)$ & $\begin{array}{l}\text { Dous }] \text { in and } \\
\text { Harrison [6] }\end{array}$ & Waxman $[46]$ & $\begin{array}{c}\text { Levelt Sengers } \\
\text { and Hastings } \\
\text { [22] }\end{array}$ & This Work \\
\hline $\begin{array}{l}448.15 \\
423.15 \\
398.15 \\
373.15 \\
348.15\end{array}$ & $\begin{array}{l}-52.4 \\
-61.6 \\
-72.3 \\
-84.8 \\
-99.7\end{array}$ & $\begin{array}{l}-52.19 \\
-61.34 \\
-72.11 \\
-84.61 \\
-99.61\end{array}$ & & \\
\hline $\begin{array}{l}323.15 \\
303.15 \\
298.15 \\
293.15 \\
288.15\end{array}$ & $\begin{array}{l}-117.7 \\
-135.0 \\
-139.8 \\
-144.9 \\
-150.3\end{array}$ & $\begin{array}{l}-117.69 \\
-139.82\end{array}$ & & \\
\hline $\begin{array}{l}283.15 \\
282.35 \\
278.15 \\
273.15 \\
268.15 \\
263.15 \\
258.15 \\
253.15 \\
248.15 \\
243.15 \\
238.15 \\
235 \\
233.15 \\
230 \\
223.15 \\
220 \\
210\end{array}$ & $\begin{array}{l}-155.7 \\
-156.7 \\
-161.6 \\
-167.6 \\
-174.1 \\
-180.9 \\
-188.1 \\
-195.5 \\
-203.5 \\
-212.0 \\
-220.9\end{array}$ & -167.67 & $\begin{array}{l}-162.53 \\
-180.58 \\
-194.71 \\
-211.57 \\
-228.78 \\
-249.17\end{array}$ & $\begin{array}{r} \\
-226.5 \\
-236.6 \\
-259.1 \\
-286.0\end{array}$ \\
\hline $\begin{array}{l}200 \\
190 \\
180 \\
170 \\
160\end{array}$ & & & & $\begin{array}{l}-318.5 \\
-358.4 \\
-407.9 \\
-469.6 \\
-545.8\end{array}$ \\
\hline $\begin{array}{l}150 \\
140 \\
130 \\
120 \\
110 \\
100\end{array}$ & & & & $\begin{array}{l}-638.4 \\
-746.3 \\
-881.4 \\
-1104.7 \\
-1427.6 \\
-1911.9\end{array}$ \\
\hline
\end{tabular}


convenience of the reader. Temperatures in the table are given on the International Practical Temperature Scale of 1968. There is good agreement among the results of the three independent experiments. The values below $235 \mathrm{~K}$ were obtained by the authors by means of a simultaneous fit of Douslin and Harrison [6], Waxman [46] and the velocity of sound data by Gammon [9]. These values were not used in the fit of the final equation of state [eq (1)] but were used to determine saturated vapor densities at temperatures below $235 \mathrm{k}$.

\section{Weighting of the Data}

Each data point used in the least squares determination of the coefficients of the equation of state was assigned a weighting factor based upon estimates of uncertainties of the variables reported by the experimenter. In most cases these estimated uncertainties were taken from assessments of the overall accuracy of the data sets. Where reiliable estimates of uncertainties were not available, estimated accuracies were determined by comparison to preliminary least squares representations of the surface. The weights used in the fitting process were calculated using approximating functions and the error propagation formula. In several instances, the error propagation weights were modified by the assignment of arbitrary multiplicative factors to increase or lessen the effect of a particular data set on the overall representation of the surface.

4. The Determination of the Equation of State

4.1 Analysis of the Functional Form of the Equation of State

Several functional representations were suggested as possible forms for the equation of state for ethylene. Among these are a 32-term modified BenedictWebb-Rubin (BWR) equation originally proposed in Jacobsen [18], and four other forms which utilize stepwise regression methods to select individual terms from an initial comprehensive function containing a large number (50 to 80 ) of possible terms. These four forms include an 80-term modified BWR equation, two 50-term modified BWR equations (one using reduced coordinates and the other a dimensional form), and a 51-term fundamental equation which has been used successfully for other fluids (Jacobsen, et al. [19] and Mui, et a]. [29]). For the ethylene data set described in this work, no clear preference for one of these forms over the others could be established on the basis of the quality of the fit of the data, and it was decided to use the pressure explicit dimensional 
BWR equation proposed in Jacobsen [18] to represent the data for ethylene excluding a wide range of values near the critical point. This equation form is widely used for other fluids and has been shown to exhibit correct thermodynamic behavior for much of the surface of state. The equation form is given as eq (1). . $^{11}$

$$
\begin{aligned}
P=\rho R T & +\rho^{2}\left(N_{1} T+N_{2} T^{T / 2}+N_{3}+N_{4} / T+N_{5} / T^{2}\right) \\
& +\rho^{3}\left(N_{6} T+N_{7}+N_{8} / T+N_{9} / T^{2}\right) \\
& +\rho^{4}\left(N_{10} T+N_{1 i}+N_{12} / T\right)+\rho^{5}\left(N_{13}\right) \\
& +\rho^{6}\left(N_{14} / T+N_{15} / T^{2}\right)+\rho^{7}\left(N_{16} / T\right) \\
& +\rho^{8}\left(N_{1 /} / T+N_{18} / T^{2}\right)+\rho^{9}\left(N_{19} / T^{2}\right) \\
& +\rho^{3}\left(N_{20} / T^{2}+N_{21} / T^{3}\right) \exp \left(-\gamma \rho^{2}\right) \\
& +\rho^{5}\left(N_{22} / T^{2}+N_{23} / T^{4}\right) \exp \left(-\gamma \rho^{2}\right) \\
& +\rho^{7}\left(N_{24} / T^{2}+N_{25} / T^{3}\right) \exp \left(-\gamma \rho^{2}\right) \\
& +\rho^{9}\left(N_{26} / T^{2}+N_{27} / T^{4}\right) \exp \left(-\gamma \rho^{2}\right) \\
& +\rho^{11}\left(N_{28} / T^{2}+N_{29} / T^{3}\right) \exp \left(-\gamma \rho^{2}\right) \\
& +\rho^{13}\left(N_{30} / T^{2}+N_{31} / T^{3}+N_{32} / T^{4}\right) \exp \left(-\gamma \rho^{2}\right)
\end{aligned}
$$

\subsection{The Selection of Data for Multiproperty Fitting}

This equation of stace for ethylene was determined using experimental thermodynamic data includilic s slected $P-p-T, C_{v}, C_{\sigma}$, velocity of sound data, and data to define saturatici, states to satisfy the Maxwell criterion for phase equilibrium. The P-p-T data selected for use in the least squares fitting process are illustrated in figure 4. The $c_{y}$ data of Weber [47] used in the least squares fit were 7 points on the $11.8 \mathrm{~mol} / \mathrm{dm}^{3}$ isochore, 13 points at

The nonlinear coefficient, $\gamma=0.0172$, in each exponential term was specified prior to the determination of the linear coefficients. 


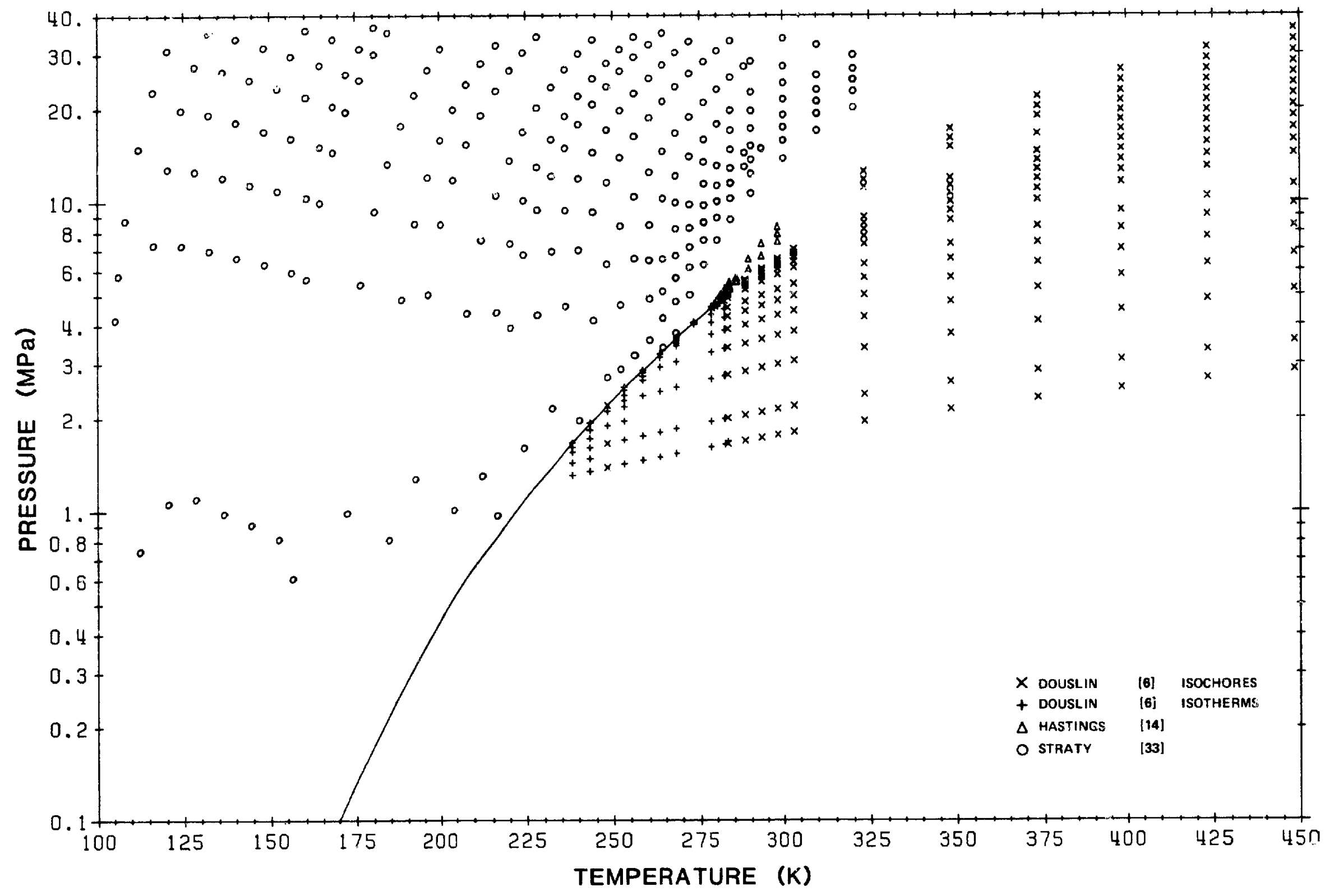

Figure 4. Ethylene PVT Data Used in the Determination of the Equation of State 
$15.6 \mathrm{~mol} / \mathrm{dm}^{3}$ and 4 points at $19.9 \mathrm{~mol} / \mathrm{dm}^{3}$. The velocity of sound data used in determining the equation of state data are illustrated in figure 5 .

The multiproperty fitting procedures used here suggest the existence of systematic inconsistencies among the various data. The data sets winich were not used in determining the final constants are those which seened to exacerbate the problem of overall consistency. However, the authors were unable to determine the exact nature of the inconsistencies, and no conclusion as to probable or possible systematic errors within any given data set can be inferred from this work. Although the data near the critical point were excluded from the selected set, the critical point of the equation of state was constrained to the values $T_{C}=282.3428 \mathrm{~K}, P_{C}=5.0403 \mathrm{MPa}$, and $\rho_{C}=7.6340 \mathrm{~mol} / \mathrm{dm}^{3}$. A later value of the critical temperature given in [14] is $282.3452 \mathrm{~K}$. The equation of state for ethylene reported here, eq (1) with coefficients from table 4 , has been compared to selected data sets to iilustrate its accuracy. These comparisons are presented in section 8 and 9. Coefficients for tile equation of state (1) for ethylene are given in table 4.

\section{Liquid-Vapor and Liquid-Solid isexistence}

\subsection{Liquid-Vapor Coexistence}

The most difficult part of the fluid surface to model mathematically is that defining the liquid-vapor coexistence conditions. Even excluding the critical region, $T=T_{c} \pm .05 T_{c}$ and $\rho=\rho_{c} \pm .3 \rho_{c}$, where the equation of state is not valid, the rest of the two phase boundary is subject to errors in representation which may be most obvious in the derivative properties at saturation, i.e., $C_{v}, C_{p}$, and velocity of sound.

The procedure used here was to first obtain equations for the vapor pressure, the saturated vapor density, and the saturated liquid density as functions of saturation temperature. These equations, togetiner with the condition of equality of Gibbs free energy for the coexisting liquid and vapor phiases, were then used as input data in the least squares fit of the equation of state.

Recent vapor pressure data for ethylene are summarized in table 5 . The vapor pressure equation for ethylene has been determined using the data of Sammon [9], Straty [33], Hastings and Levelt Sengers [13], Douslin and Harrison [6], and Bigeleisen, et 21. [3]. The equation used in this work is 


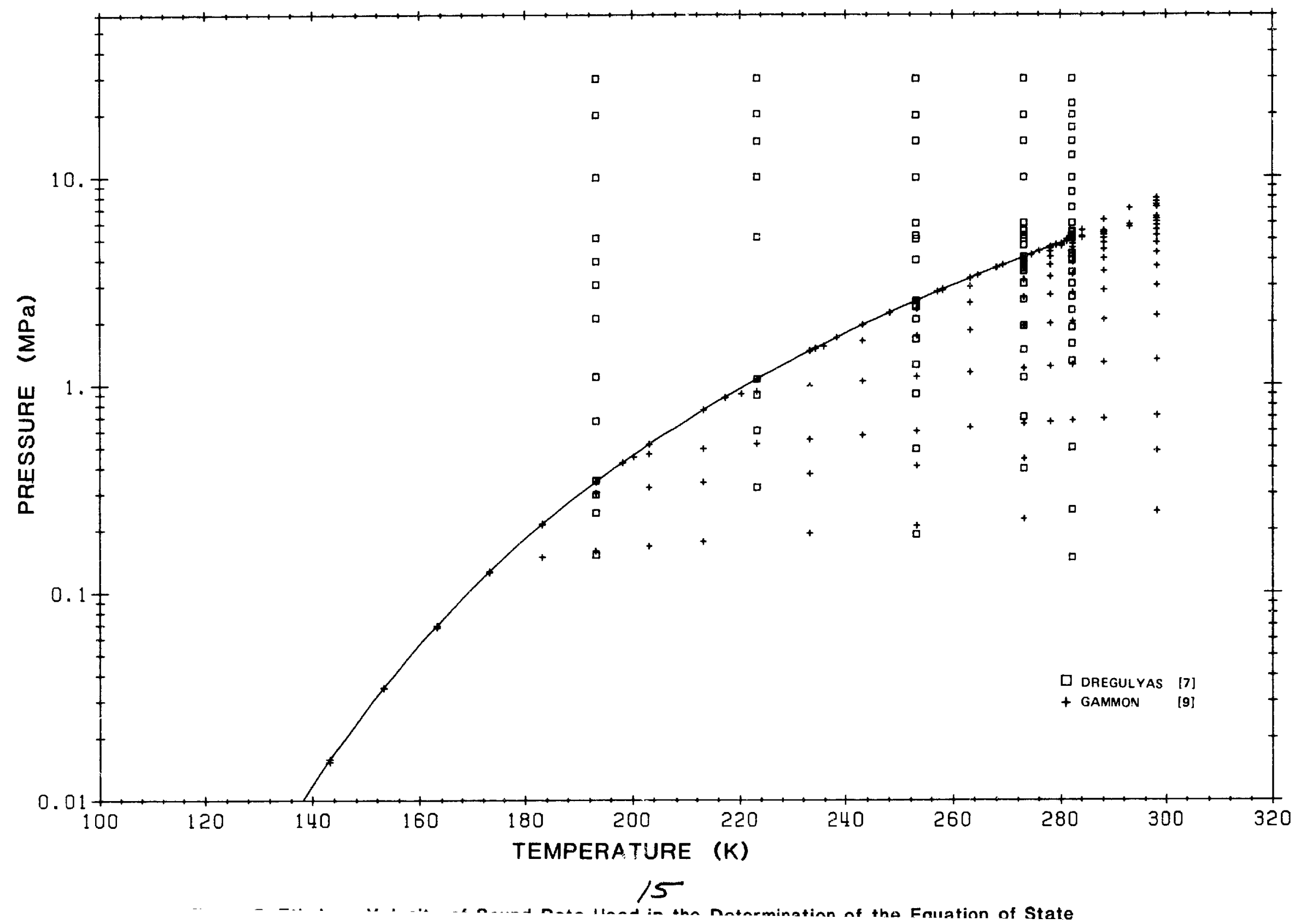


Table 4. Coefficients for the Equation of State (1) for Ethylene ${ }^{12}$

$$
\begin{aligned}
& N_{1}=-.2146684366683 \mathrm{E}-02 \\
& N_{2}=.1791433722534 E+00 \\
& N_{3}=-.3675315603930 E+01 \\
& \mathrm{~N}_{4}=.3707178934669 \mathrm{E}+03 \\
& \mathrm{~N}_{5}=-.3198282566709 \mathrm{E}+05 \\
& N_{6}=.5809379774732 \mathrm{E}-04 \\
& \mathrm{~N}_{7}=-.7895570824899 \mathrm{E}-01 \\
& N_{8}=.1148620375835 E+02 \\
& N_{9}=.2713774629193 E+05 \\
& \mathrm{~N}_{10}=-.8647124319107 \mathrm{E}-05 \\
& N_{11}=.1617727266385 E-01 \\
& \mathrm{~N}_{12}=-.2731527496271 \mathrm{E}+01 \\
& N_{13}=-.2672283641459 \mathrm{E}-03 \\
& N_{14}=-.4752381331990 \mathrm{E}-02 \\
& N_{15}=-.6255637346217 \mathrm{E}+01 \\
& N_{16}=.4576234964434 \mathrm{E}-03 \\
& \mathrm{~N}_{17}=-.7534839269320 \mathrm{E}-05 \\
& \mathrm{~N}_{18}=.1638171982209 \mathrm{E}-01 \\
& \mathrm{~N}_{19}=-.3563090740740 \mathrm{E}-03 \\
& N_{20}=-.1833000783170 E+05 \\
& N_{21}=-.1805074209985 E+07 \\
& \mathrm{~N}_{22}=-.4794587918874 \mathrm{E}+03 \\
& N_{23}=.3531948274957 E+07 \\
& \mathrm{~N}_{24}=-.2562571039155 \mathrm{E}+01 \\
& \mathrm{~N}_{25}=.1044308253292 \mathrm{E}+03 \\
& N_{26}=-.1695303363659 \mathrm{E}-01 \\
& \mathrm{~N}_{27}=-.1710334224958 \mathrm{E}+\mathrm{O} 3 \\
& N_{28}=-.2054114462372 E-04 \\
& \mathrm{~N}_{29}=.6727558766661 \mathrm{E}-02 \\
& N_{30}=-.1557168403328 \mathrm{E}-06 \\
& N_{31}=-.1229814736077 \mathrm{E}-04 \\
& \mathrm{~N}_{32}=.4234325938573 \mathrm{E}-04 \\
& \gamma=0.0172 \\
& \mathrm{R}=.00831434
\end{aligned}
$$

12 Coefficients are given for temperature in kelvins, pressure in MPa, and density in $\mathrm{mol} / \mathrm{dm}^{3}$. 


$$
\ln P=N_{1}+N_{2} x+N_{3} x^{2}+N_{4} x^{3}+N_{5} x^{4}+N_{6} x(1-x)^{N_{7}}
$$

where, $x=\left(1-T_{t p} / T\right) /\left(1-T_{t p} / T_{c}\right)$

Table 5. Sumrnary of Vapor Pressure Data for Ethylene

\begin{tabular}{lcc} 
Author & $\begin{array}{c}\text { Temperature Range } \\
\text { Kelvins }\end{array}$ & $\begin{array}{c}\text { No. of } \\
\text { Points }\end{array}$ \\
\hline 1. Bigeleisen, et al. [3] & $104-176$ & 31 \\
2. Douslin and Harrison [6] & $238-282$ & 18 \\
3. Gammon [9] & $104-282$ & 28 \\
4. Hichels and Wassenaar [26] & $149-281$ & 30 \\
5. Hastings and Sengers [13] & $220-282$ & 35 \\
6. Straty [33] & $200-282$ & 27 \\
7. Tickner and Lossing [39] & $95-138$ & 24
\end{tabular}

13 This reference also contains vapor pressures for states below the triple point temperature. Values given in the reference are rounded values. Angus [1], page 3, gives 11 experimental values of the vapor pressure supplied by Lossing. These data have been omitted from comparisons in this section because of their apparent lack of agreenent with other vapor pressure data for ethylene.

The values of $T_{t p}$ and $T_{c}$ for use in this equation are $T_{t p}=103.986 \mathrm{~K}$ and $T_{c}=282.3428 \mathrm{~K}$. The coefficients of this equation for pressure in $\mathrm{MPa}$ and temperature in kelvins are given in table 6 . Comparisons of values of saturation temperature calculated from the vapor pressure equation at data point pressures with the measured temperatures are given in figure 6 . Three values from Gammon [9] for temperatures from 104-113 K exhibit deviations of from -0.8 to $-1.8 \mathrm{~K}$ and are not included in figure 6 . Saturated liquid and vapor density data used in constructing the two phase boundaries as outlined above are summarized in table 7 . 

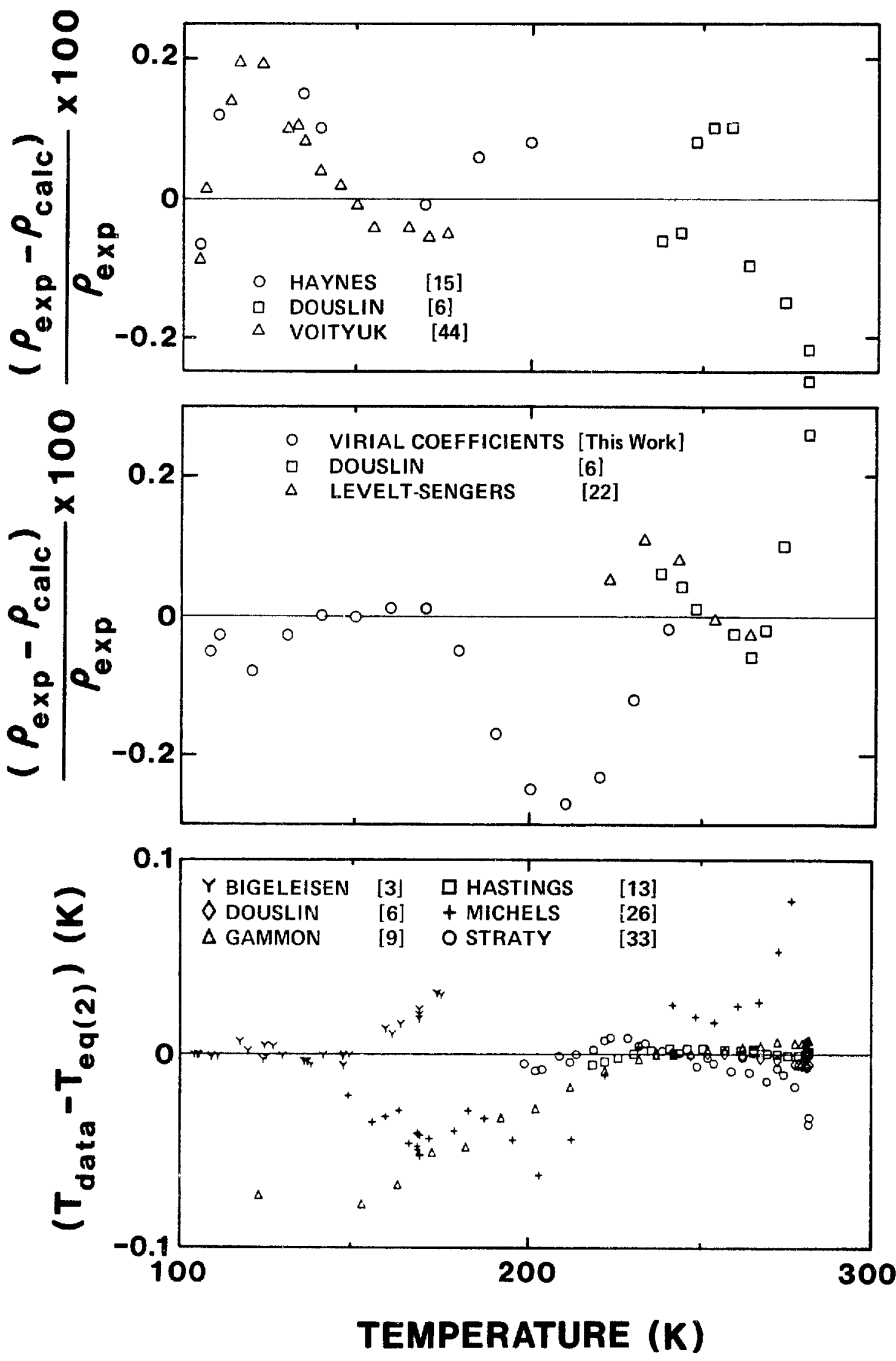

Figure 6. Comparisons of PVT Values at Saturation $\underline{18}$ 
Table 6. Coefficients for the Vapor Pressure Eq (2) for Ethylene

$$
\begin{aligned}
& N_{1}=-9.017286635 \\
& N_{2}=3.209579800 \\
& N_{3}=4.315424145 \\
& N_{4}=-1.692585975 \\
& N_{5}=-0.1976495575 \\
& N_{6}=3.446501098 \\
& N_{7}=1.5
\end{aligned}
$$

Table 7. Summary of Saturation Density Data Used in This Nork

\begin{tabular}{llcc}
\hline \multicolumn{1}{c}{ Author } & Phase & $\begin{array}{c}\text { Temperature Range } \\
\text { Kelvins }\end{array}$ & $\begin{array}{c}\text { No. of } \\
\text { Points }\end{array}$ \\
\hline Douslin and Harrison [6] & Liquid & $238-282$ & 14 \\
& Vapor & $238-281$ & 12 \\
Golovskii and Tsymarnyi [10] & Liquid & $105-260$ & 30 \\
Hastings and Levelt-Sengers [13] & Liquid & $279-282$ & 9 \\
Levelt-Sengers and Hastings [22] & Vapor & $220-253$ & 5 \\
Haynes [15] & Liquid & $105-200$ & 7 \\
Menes [24] & Liquid & $105-175$ & 15 \\
\hline
\end{tabular}

The function for the saturated liquid density is

$$
\begin{gathered}
Y=A_{1} \ln x+\sum_{i=2}^{4} A_{i}\left[1-x^{(i-5) / 3}\right]+\sum_{i=5}^{7} A_{i}\left[1-x^{(i-4) / 3}\right] \\
\rho_{\text {sat1 }}=\rho_{c}+e^{Y}\left(\rho_{\text {tp } 1}-\rho_{c}\right),
\end{gathered}
$$

where $x=\left(T-T_{c}\right) /\left(T_{t p}-T_{c}\right)$ and that for the saturated vapor density is 


$$
\begin{aligned}
Y=A_{i} & \ln (x)+\sum_{i=2}^{4} A_{i}\left[1-x^{(i-5) / 3}\right]+\sum_{i=5}^{13} A_{i}\left[1-x^{(i-4) / 3}\right] \\
\rho_{\text {satv }} & =\rho_{c}+e^{Y}\left(\rho_{\text {tpv }}-\rho_{c}\right),
\end{aligned}
$$

where $x$ is as defined above. The coefficients for these equations used to represent the saturated iiquid and vapor densities are given in table 8 . These functions for the saturated liquid and saturated vapor densities are also useful to obtain a first approximation to the saturation density when solving the equation of state iteratively for the conditions at phase equilibrium.

Table 8. Coefficients for Approximating Functions for Saturation Densities for Ethylene ${ }^{14}$

Coefficients for Saturated Vapor (eq 4)
Coefficients for Saturated Liquid (eq 3)

$$
\begin{aligned}
& \rho_{\text {tpv }}=.142545512709 \mathrm{E}-03 \\
& A_{1}=-.609621515594 \mathrm{E}+02 \\
& A_{2}=.203185312702 \mathrm{E}-01 \\
& A_{3}=-.925441265813 \mathrm{E}+00 \\
& A_{4}=.243630795888 \mathrm{E}+02 \\
& A_{5}=-.354745622888 \mathrm{E}+03 \\
& A_{6}=.123927868183 \mathrm{E}+04 \\
& A_{7}=-.142710711789 \mathrm{E}+04 \\
& A_{8}=.837358670405 \mathrm{E}+03 \\
& A_{9}=.432203696552 \mathrm{E}+03 \\
& A_{10}=-. .137917541161 \mathrm{E}+04 \\
& A_{11}=.126858600124 \mathrm{E}+04 \\
& A_{12}=-.571552321713 \mathrm{E}+03 \\
& A_{13}=.106012234360 \mathrm{E}+03
\end{aligned}
$$

$$
\begin{aligned}
& \rho_{\text {tp } 1}=.233429669403 \mathrm{E}+02 \\
& A_{1}=-.479047060183 \mathrm{E}+01 \\
& A_{2}=.151381345283 \mathrm{E}-01 \\
& A_{3}=-.403456079445 \mathrm{E}+00 \\
& A_{4}=.508683920225 \mathrm{E}+01 \\
& A_{5}=-.246711997987 \mathrm{E}+02 \\
& A_{6}=.980030915247 \mathrm{E}+01 \\
& A_{7}=-.216846516122 \mathrm{E}+01
\end{aligned}
$$

$\overline{14}$ Coefficients are given for $T$ in kelvins and $\rho$ in $\mathrm{mol} / \mathrm{dm}^{3}$. 
The table of saturation properties in Appendix 3 was calculated by specifying $T$ and then solving the vapor pressure equation, (2), for the saturation pressure. Using the P-T coordinates of a vapor pressure point, the equation of state (1) was then solved for the density of the saturated liquid and vapor using an appropriate iterative procedure. Figure 6 illustrates the agreement between the densities calculated in the above manner and corresponding values from various sources.

An alternative method of calculating the saturation properties is to solve the equation of state for the thermodynamic conditions for coexisting phases, i.e., equal Gibbs free energy for constant $P$ and $T$. This calculation is accomplished by equating Gibbs free energy of the liquid to the Gibbs free energy of the vapor and the pressure of the liquid equal to the pressure of the vapor at a cominon temperature. This results in two equations in two unknows, i.e., density of the vapor and density of the liquid. As a matter of interest this calculation was done for the equation of state reported here and the results are shown in table 9 .

\subsection{Liquid-Solid Coexistence}

The melting line equation used in this work is taken from Straty [33]. This equation is

$$
P=0.00012+357.924\left(T / T_{t p}-1.0\right)^{2.0645}
$$

for pressure in $\mathrm{MPa}$ and temperature in kelvins where $T_{t p}$ is $103.986 \mathrm{~K}$.

\section{The Idea 1 Gas Heat Capacity Equation}

The ideal gas isobaric heat capacity values from Angus, et al. [1] for temperatures from 100 to $500 \mathrm{~K}$ have been represented by an equation suggested by Barieau [2].

$C_{p}^{0} / R=N_{1} / T^{3}+N_{2} / T^{2}+N_{3} / T+N_{4}+N_{5} T+N_{6} T^{2}+N_{7} T^{3}+N_{8} u^{2} e^{u} /\left(e^{u}-1\right)^{2}$,

where $C_{p}^{0}$ is the ideal gas heat capacity, $T$ is the temperature in kelvins, and $u=N_{9} / T$. The coefficients of eq (6) for temperatures in kelvins are given in table 10 . 
Table 9. Differences Between Saturation Properties Calculated From Equation of State (1) Using the Maxwell Criterion and the Intersection of the Vapor Pressure eq (2) With the Equation of State (1).

\begin{tabular}{|c|c|c|c|c|c|}
\hline $\begin{array}{l}\text { Temp. } \\
\text { K }\end{array}$ & $\begin{array}{c}\Delta \mathrm{P}^{15} \\
(\mathrm{MPa})\end{array}$ & $\begin{array}{l}\Delta \rho_{\text {vapor }} \\
\left(\mathrm{mol} / \mathrm{dm}^{3}\right)\end{array}$ & $\begin{array}{c}\Delta \rho_{1 \mathrm{iq}} \\
\left(\mathrm{mol} / \mathrm{dm}^{3}\right)\end{array}$ & $\begin{array}{l}\Delta G_{\text {vapor }} \\
(\mathrm{J} / \mathrm{mol})\end{array}$ & $\begin{array}{l}\Delta G_{1 i q} \\
(\mathrm{~J} / \mathrm{mol})\end{array}$ \\
\hline 110 & -0.03 & -0.3 & $-5 . \times 10^{-5}$ & 0.1 & 1. $\times 10^{-6}$ \\
\hline 120 & -0.008 & -0.08 & $-7 . \times 10^{-8}$ & 0.02 & 1. $\times 10^{-6}$ \\
\hline 130 & -0.002 & -0.02 & $-9 . \times 10^{-9}$ & 4. $\times 10^{-3}$ & 3. $\times 10^{-7}$ \\
\hline 140 & -0.006 & -0.06 & $-6 . \times 10^{-7}$ & 1. $\times 10^{-2}$ & 5. $\times 10^{-6}$ \\
\hline 150 & -0.01 & -0.1 & $-4 . \times 10^{-5}$ & 2. $\times 10^{-2}$ & 2. $\times 10^{-5}$ \\
\hline 160 & -0.02 & -0.2 & $-5 . \times 10^{-5}$ & 2. $\times 10^{-2}$ & 7. $\times 10^{-5}$ \\
\hline 170 & -0.02 & -0.2 & $-4 . \times 10^{-4}$ & 4. $\times 10^{-2}$ & 1. $\times 10^{-4}$ \\
\hline 100 & -0.02 & -0.3 & $-9 \cdot \times 10^{-5}$ & 3. $\times 10^{-2}$ & 2. $\times 10^{-4}$ \\
\hline 190 & -0.02 & -0.2 & $-2 . \times 10^{-4}$ & 3. $\times 10^{-2}$ & 3. $\times 10^{-4}$ \\
\hline 200 & -0.02 & -0.2 & $-2 . \times 10^{-4}$ & 1. $\times 10^{-2}$ & 3. $\times 10^{-4}$ \\
\hline 210 & -0.009 & -0.1 & $-2 . \times 10^{-4}$ & 9. $\times 10^{-3}$ & 2. $\times 10^{-4}$ \\
\hline 220 & -0.003 & -0.04 & $-1 . \times 10^{-4}$ & 3. $\times 10^{-3}$ & 8. $\times 10^{-5}$ \\
\hline 230 & 0.001 & 0.01 & 2. $\times 10^{-4}$ & $-9 . \times 10^{-4}$ & $-1 . \times 10^{-4}$ \\
\hline 240 & 0.004 & 0.05 & $8 . \times 10^{-4}$ & $-3 . \times 10^{-3}$ & $-3 . \times 10^{-4}$ \\
\hline 250 & 0.005 & 0.08 & 2. $\times 10^{-3}$ & $-3 . \times 10^{-3}$ & $-5 . \times 10^{-4}$ \\
\hline 260 & 0.004 & 0.08 & 4. $\times 10^{-3}$ & $-2 . \times 10^{-3}$ & $-5 . \times 10^{-4}$ \\
\hline 270 & 0.002 & 0.07 & $8 . \times 10^{-3}$ & $-8 \cdot \times 10^{-4}$ & $-4 . \times 10^{-3}$ \\
\hline
\end{tabular}

15 All property diffurences are formed by subtracting the property obtained by using the equation of state only from the property obtained by intersecting the vapor pressure equation with the equation of state. 
Table 10. Coefficients for the Ideal Gas Heat Capacity

Eq (6) for Ethylene

$$
\begin{aligned}
& N_{1}=0.5603615762 \mathrm{E}+6 \\
& N_{2}=-0.2141069802 \mathrm{E}+5 \\
& N_{3}=0.2532008897 \mathrm{E}+3 \\
& N_{4}=0.3554495281 \mathrm{E}+1 \\
& N_{5}=-0.9951927478 \mathrm{E}-2 \\
& N_{6}=0.5108931070 \mathrm{E}-4 \\
& N_{7}=-0.1928667482 \mathrm{E}-7 \\
& N_{8}=-0.2061703241 \mathrm{E}+2 \\
& N_{9}=0.3000000000 \mathrm{E}+4
\end{aligned}
$$

Values of the ideal gas heat capacity calculated using this equation have been compared to values calculated using the equation published by Angus, et al. [1]. The agreeiuent of these calculated values is generally within \pm 0.01 percent except at temperatures above $460 \mathrm{~K}$ where the differences increase to 0.03 percent. A comparison of values of the ideal gas heat capacity calculated using this equation with those of more recent work by Chao and Zwolinski [4], ideal gas heat capacities derived from the low density velocity of sound measurements by Moldover [28] values from Angus [1], and values from the JANAF tables [34] are shown in figure 7. Not shown in the figure are three points of Chao and Zwolinski [4] at $50 \mathrm{~K}, 319 \mathrm{~K}$, and $34 \mathrm{C} \mathrm{K}$ which exhibit deviations of -4.1 percent, -0.95 percent, and -1.25 percen't res, ectively.

\section{Derived Thermodynamic Properties}

Functions for the calculation of entropy, enthalpy, internal energy, the isotherm derivative $(\partial P / \partial \rho)_{T}$, the isochore derivative $(\partial P / \partial T)_{\rho}, C_{v}, C_{p}$, and the velocity of sound have been calculated for the thermodynamic formulation presented here. The basis for these calculations is described in this section. 


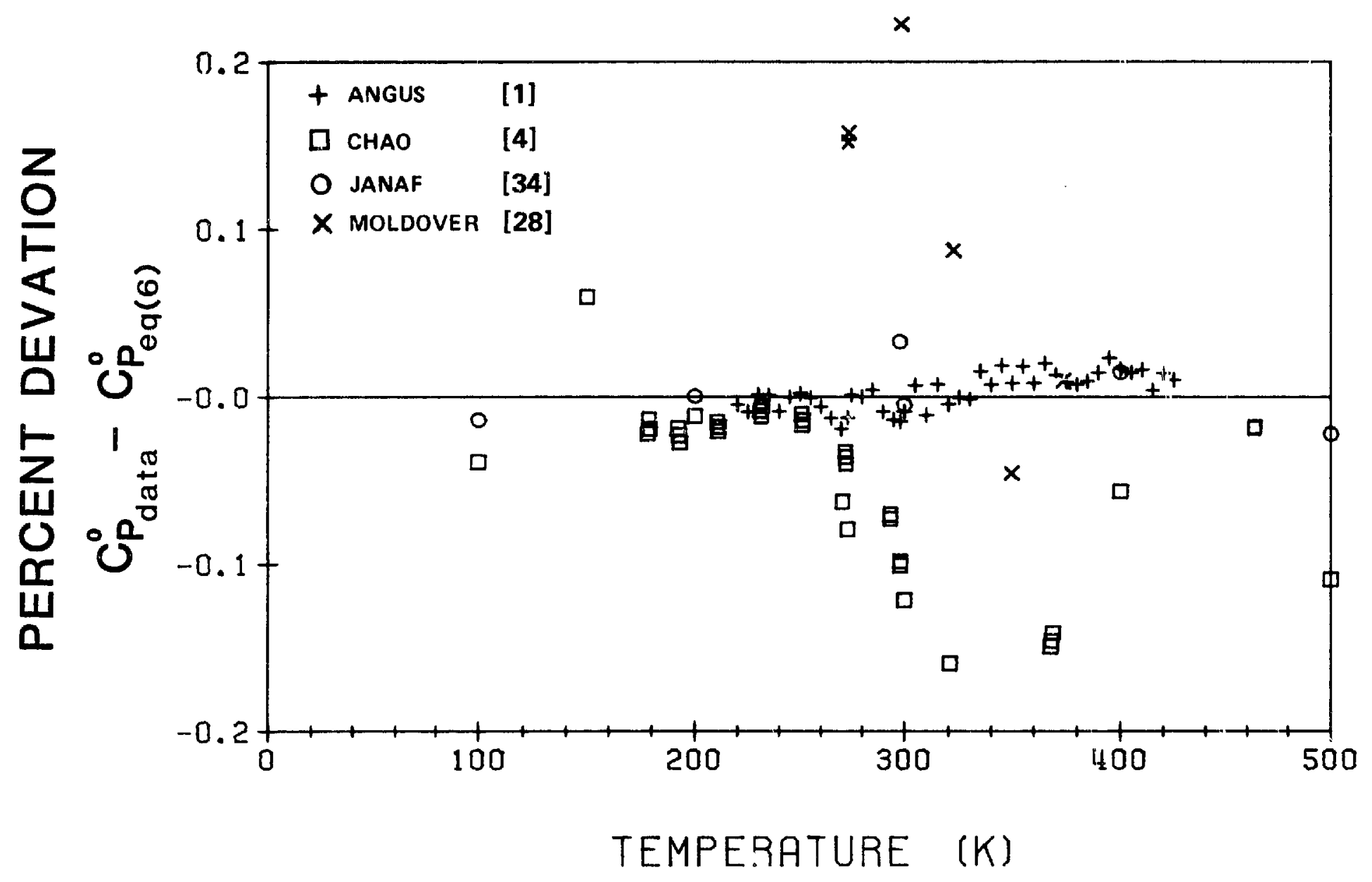

Figure 7. Comparisons of Ideal Gas Heat Capacity Values 
The entropy of any thermodynamic state may be calculated from

$$
\begin{aligned}
S(T, \rho)=S_{T_{0}}^{0} & +\int_{T_{0}}^{T}\left(C_{p}^{0} / T\right) d T-R \ln \left(R T \rho / P_{0}\right) \\
& +\int_{0}^{\rho}\left[R / \rho-\left(1 / \rho^{2}\right)(\partial P / \partial T)_{\rho}\right]_{T} d \rho .
\end{aligned}
$$

The ideal gas specific heat, $C_{p}^{0}$, is from eq $(6)$. The reference entropy of the ideal gas at $T_{0}=298.15 \mathrm{~K}$ and $P_{0}=0.101325 \mathrm{NPa}, S_{T_{0}}^{0}=219.225 \mathrm{~J} /($ mol K$)$ is taken from Angus, et a1. [1].

The enthalpy of any state may be calculated froin

$$
\begin{aligned}
H(T, \rho)=H_{T_{0}}^{0} & +T \int_{0}^{\rho}\left[(R / \rho)-\left(1 / \rho^{2}\right)(\partial P / \partial T)_{\rho}\right]_{T} d \rho \\
& +\int_{0}^{\rho}\left[\left(P / \rho^{2}\right)-(R T / \rho)_{T}\right] d \rho+(P-\rho R T) / \rho+\int_{T_{0}}^{T} C_{p}^{0} d T .
\end{aligned}
$$

The reference enthalpy of the ideal gas at $T_{0}=298.15 \mathrm{~K}$ of $H_{T_{0}}^{0}=29.610$ $\mathrm{J} / \mathrm{mol}$ was taken from Angus, et al. [1].

The internal energy of a fluid state is calculated from

$$
U(T, \rho)=H(T, \rho)-P / \rho \text {. }
$$

The specific heat at constant volume, $C_{v}$, of liquid and gas phase points is calculated using the relation

$$
C_{v}(T, \rho)=\left(C_{p}^{0}-R\right)-\int_{0}^{\rho}\left[\left(T / \rho^{2}\right)\left(\partial^{2} P / \partial T^{2}\right)_{\rho}\right]_{T} d \rho,
$$

where $C_{p}^{0}$ at temperature, $T$, is calculated froli: eq $(6)$.

The specific heat at constant pressure, $C_{p}$, is given by

$$
C_{p}(T, \rho)=C_{v}(T, \rho)+\left[\left(T / \rho^{2}\right)(\partial P / \partial T)_{\rho}^{2} /(\partial P / \partial \rho)_{T}\right] .
$$

The velocity of sound is calculated from the relation,

$$
W(T, \rho)=\left[\left(C_{p} / C_{v}\right)(\partial P / \partial \rho)_{T}\right]^{1 / 2} \text {. }
$$

The representations for the properties are continuously integrated through the two-phase region to define states in the liquid range. This was made possible by 
the fitting procedures employed in the development of the equation of state in which the conditions for two-phase equilibrium were included in the least squares determination of the coefficierits for the equation of state. A table of properties of ethylene is included in Appendix $B$.

8. Comparisons of the Equation of State to P-p-T Datü

Comparisons of values of derisity calculated using the equation of state with experimental densities used in determining the coefficients of eq (1) are included in the graphs of figure 8. Calculated density deviations for thirty-nine of the selected data points of Douslin and Harrison [6] and six data points of Hastings, et al. [14] exceeded the scale of figure 8. Thirty-four of these points of Douslin and Harrison and all of the points of Hastings are in the critical region (within \pm 30 percent of the critical density and within \pm 5 percent of the critical temperature). Comparisons to all P-p-T data including those data not used in the determination of the equation of state are given in Appendix $A$. The critical region is outside the range of this formulation; however to illustrate the actual behavior of the formulation in the critical region, comparisons with critical region data are included in Appendix $A$.

9. Comparisons of the Equation of State With Related Thermodynamic Data Although only selected thermodynanic data together with the $P-\rho-T$ data were used in determining the equation of state, comparisons to these data as well as other derived property data are given here to indicate the accuracy of the equation of state in representing these related properties. Figure 9 includes comparisons with the $C_{v}$ data of Weher [47] $]^{16}$ and with values from Gammon [9]. Table A-2 includes values of $C_{v}$ which exhibit deviations larger than the scale of figure 9 .

Comparisons to the velocity of sound data used in determining the equation of state are 111 ustrated in figure 10. Five data points of Dregulyas [7] have deviations beyond the scale of figure 10 ranging from -1.1 to -3.8 percent. Thirteen data points of Gammon [9] have absolute deviations from 1.1 to 1.7 percent, and are also excluded from figure 10 . Figure 11 is a comparison to the

$\overline{16}$ Data taken as a part of this project. 


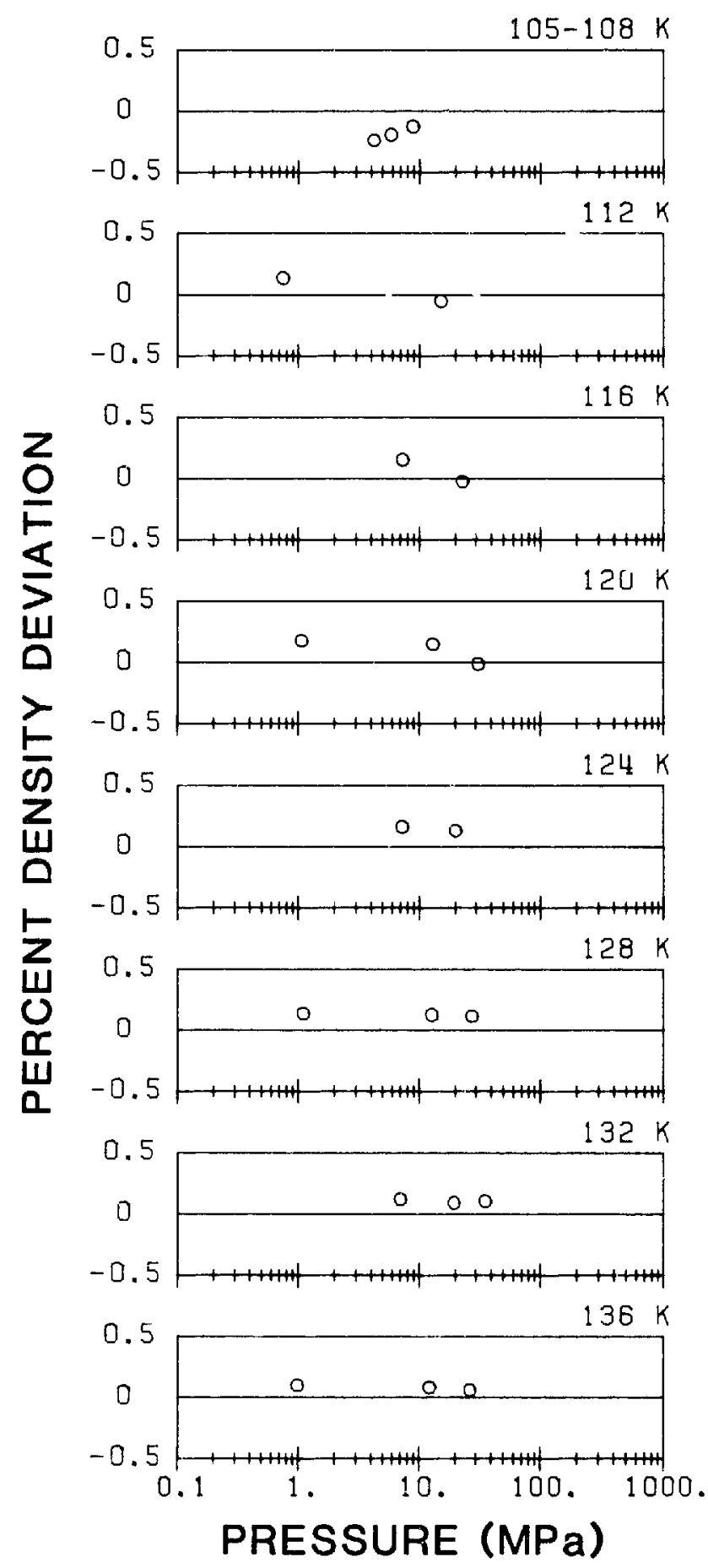

- STRATY

[33]
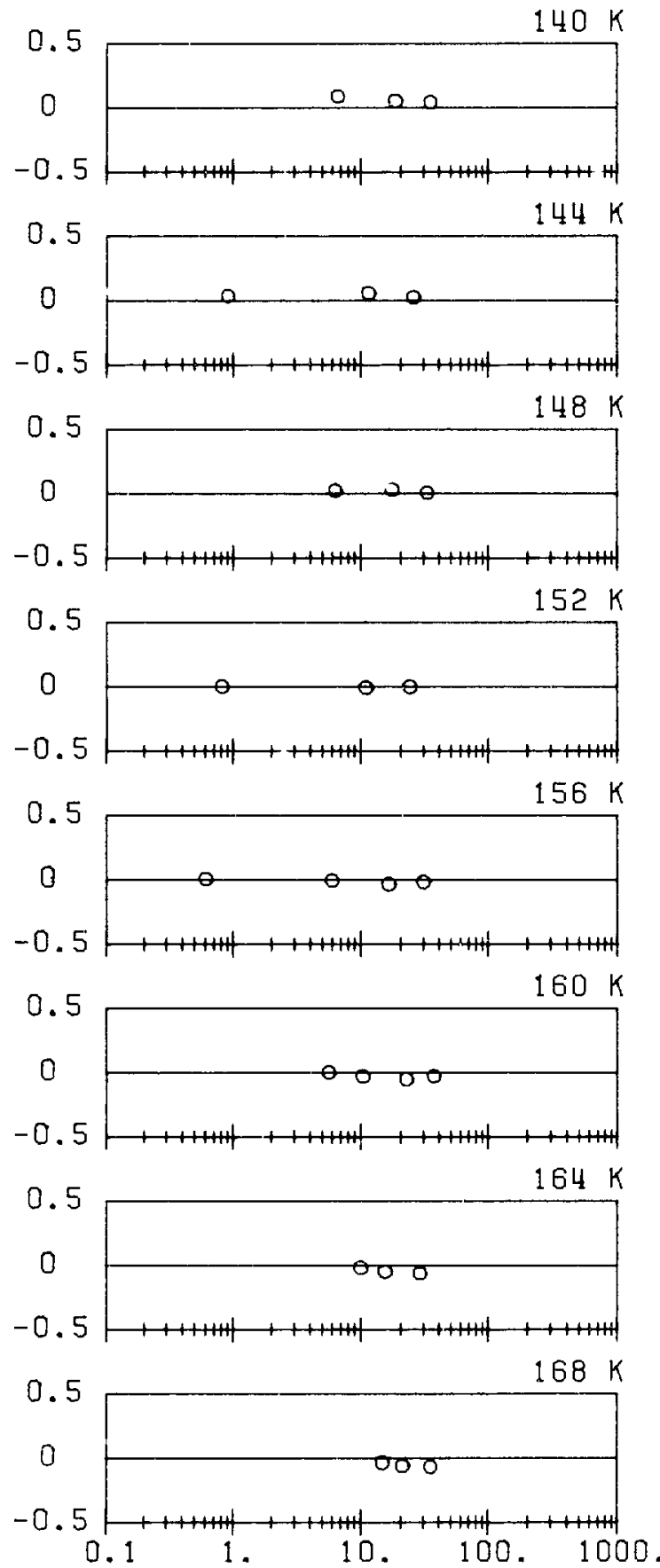

PRESSURE (MPa)

O STRATY [33]

Figure 8. Deviations of Calculated Values of Density from Selected PVT Data 


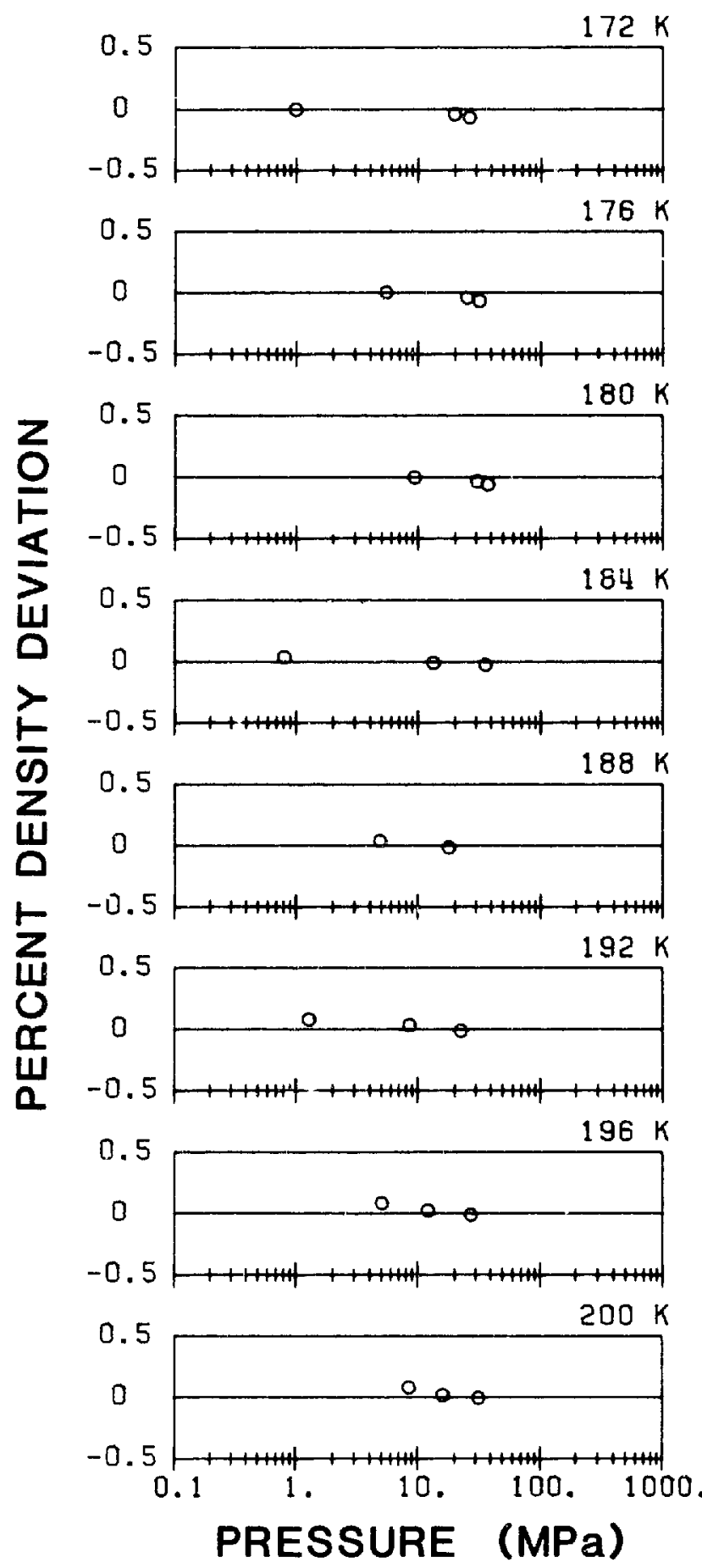

O STRATY [33]

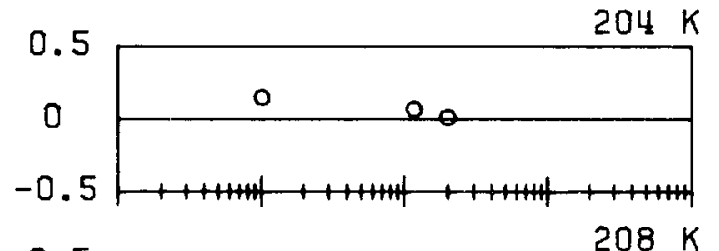

0.5
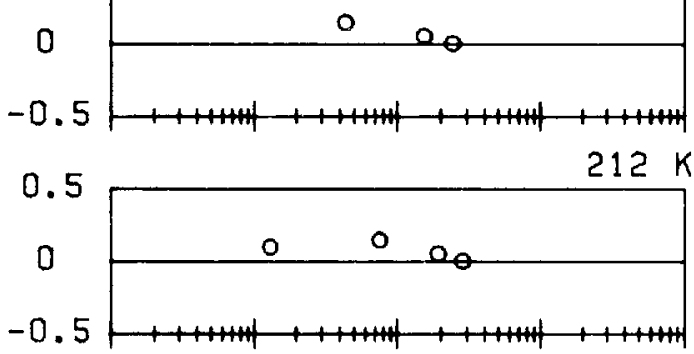

0.5
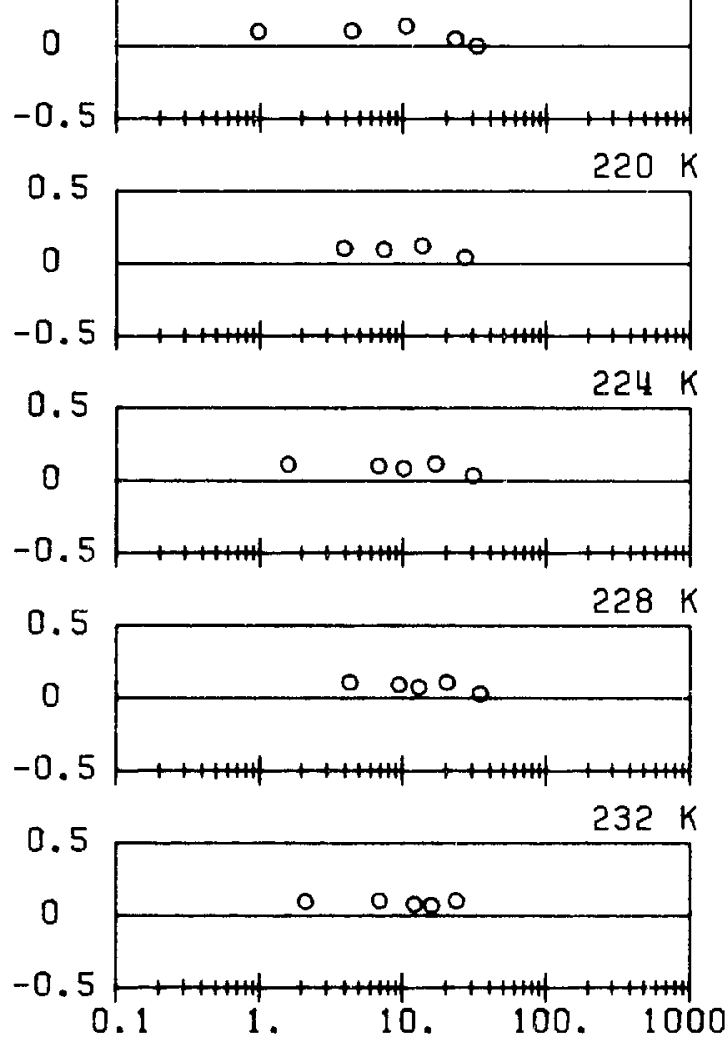

\section{PRESSURE (MPa)}

- STRATY [33]

Figure 8. Deviations of Calculated Values of Density from Selected PVT Data (Continued) 

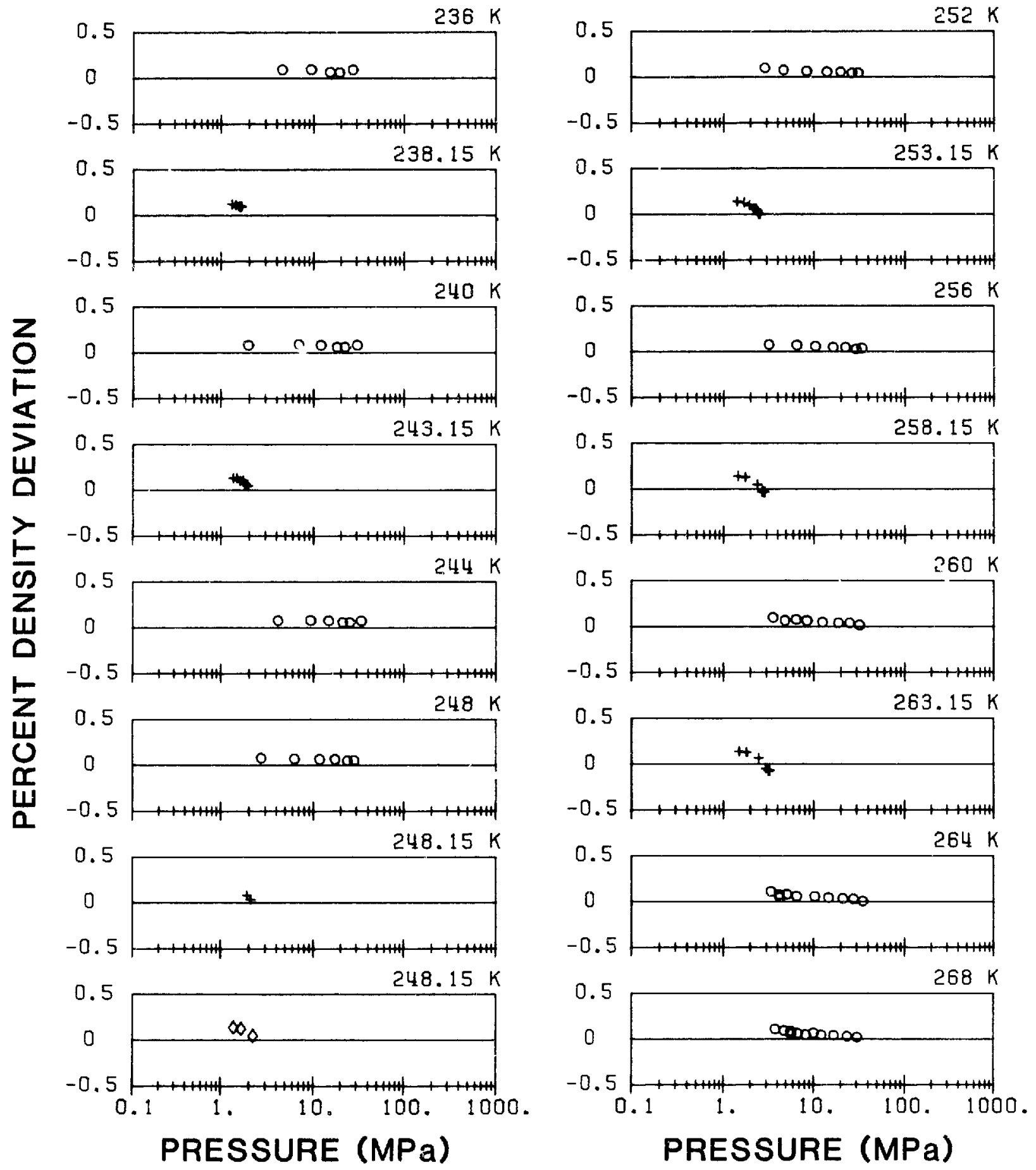

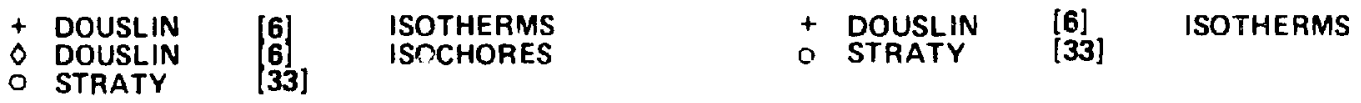

Figure 8. Deviations of Calculated Values of Density from Selected PVT Data (Continued) 

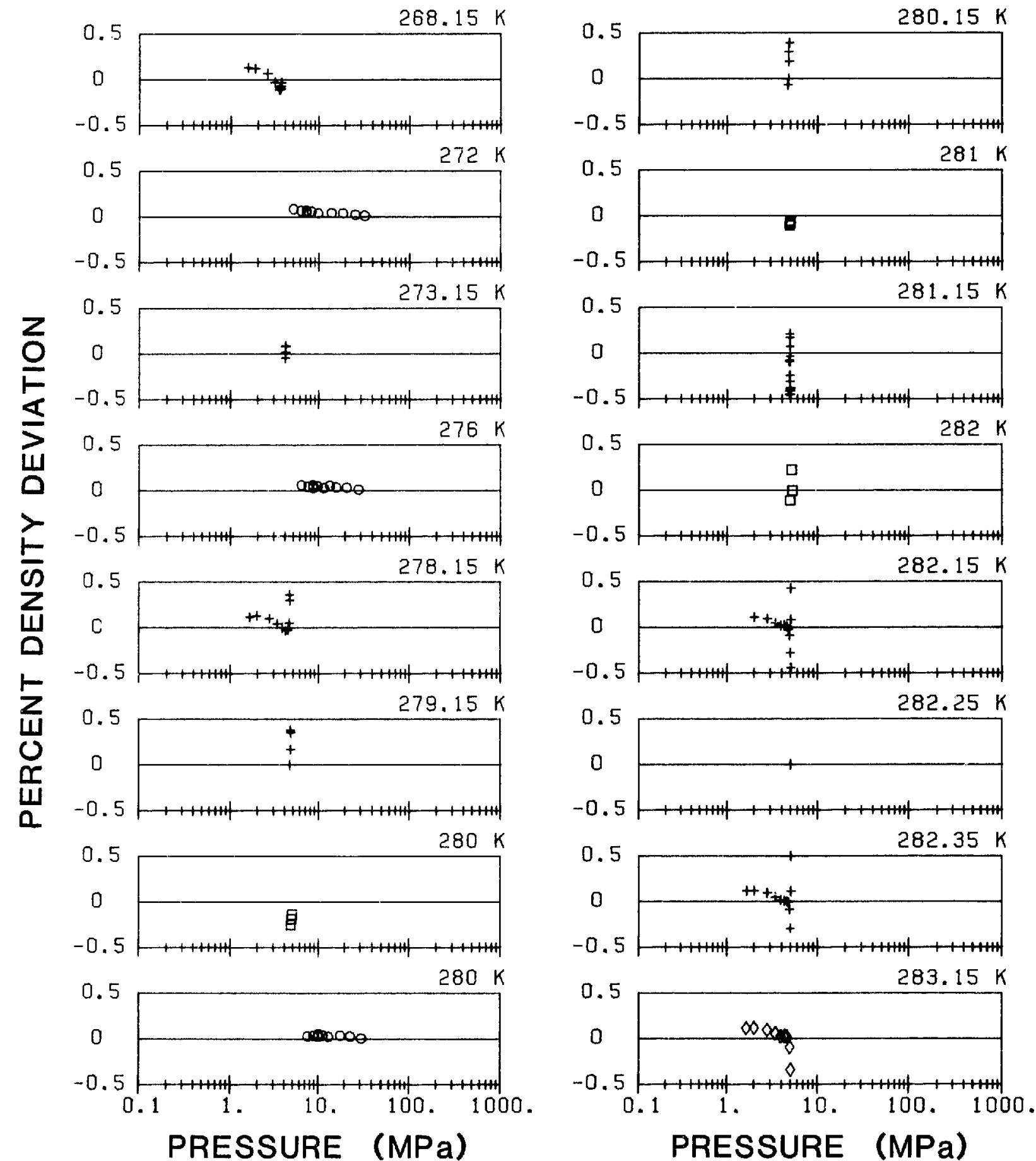

\section{PRESSURE (MPa)}
+ DOUSLIN
[6]
ISOTHERMS
+ DOUSLIN
[6]
ISOTHERMS
D HASTINGS [14]
$\checkmark$ DOUSLIN
[6]
- HASTINGS
[14]
ISOCHORES

Figure 8. Deviations of Calculated Values of Density from Selected PVT Data (Continued) 

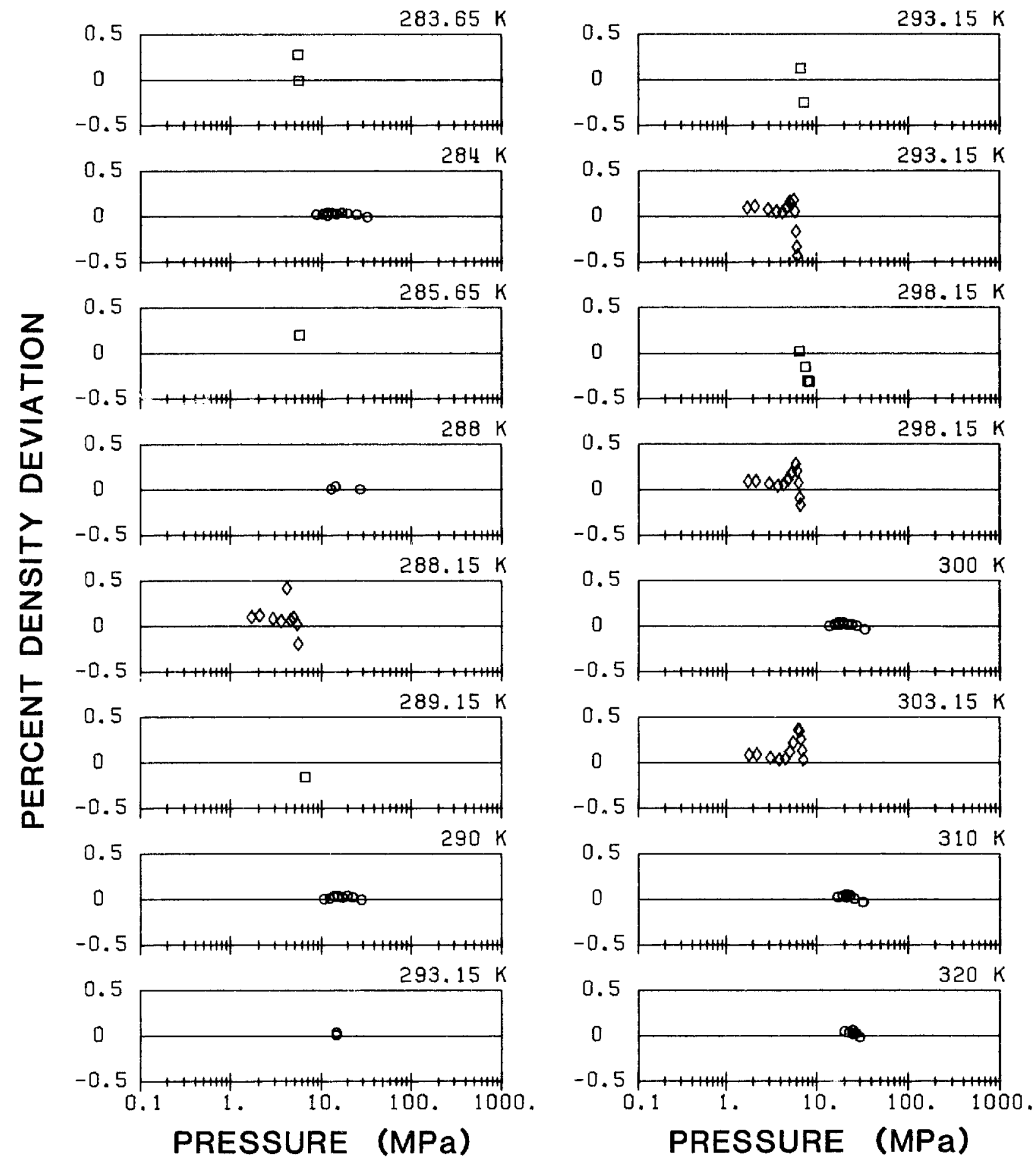

PRESSURE (MPa)
$\diamond$ DOUSLIN [6] ISOCHORES
DASTINGS [14]
$\begin{array}{lll}\circ & \text { DOUSLIN } & {[6]} \\ \square & \text { HASTINGS } & {[14]}\end{array}$
ISOCHORES
O STRATY [33]
O STRATY [33]

Figure 8. Deviations of Calculated Values of Density from Selected PVT Data (Continued) 


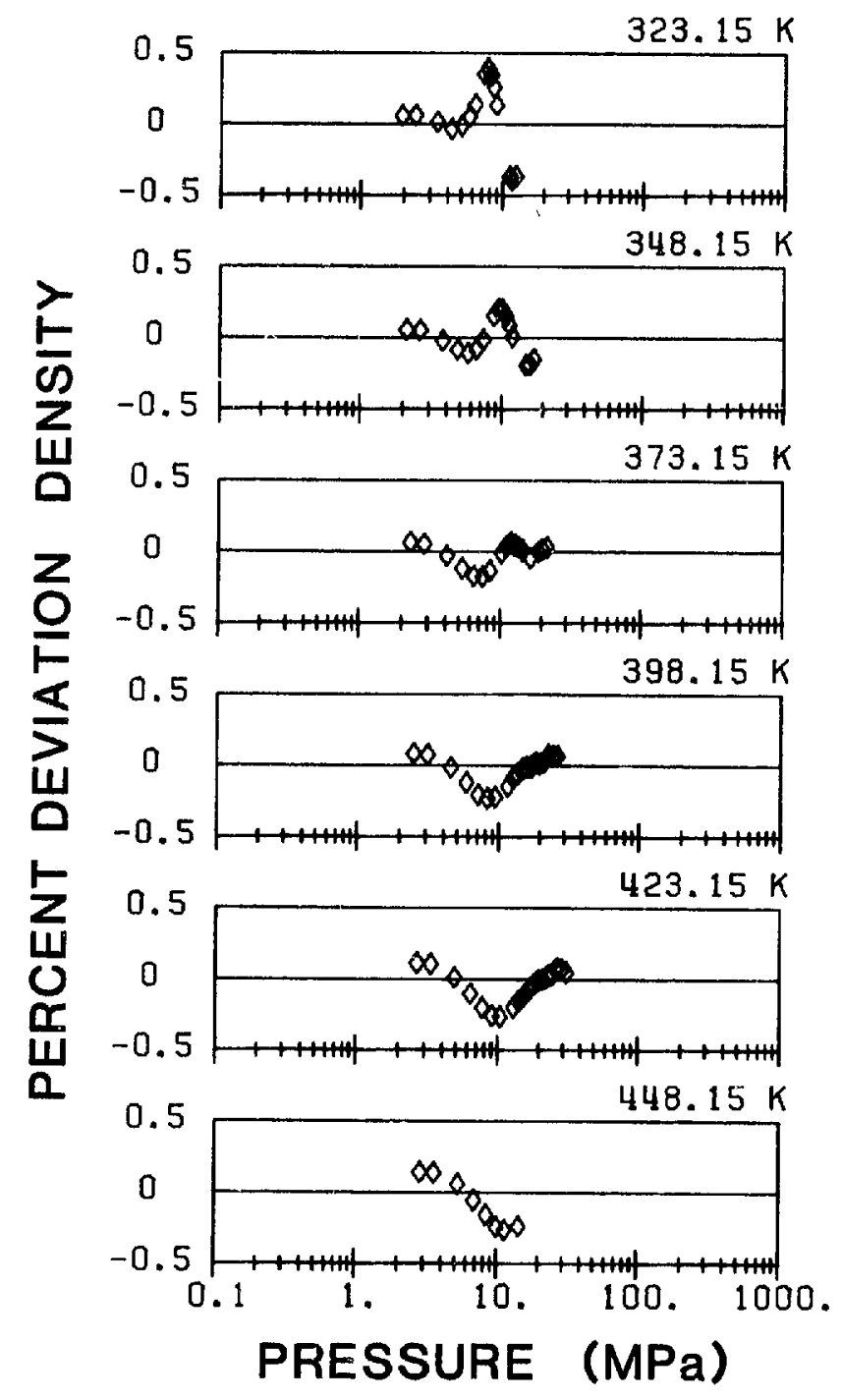

$\diamond$ DOUSLIN [6] ISOCHORES

Figure 8. Deviations of Calculated Values of Density from Selected PVT Data (Continued) 


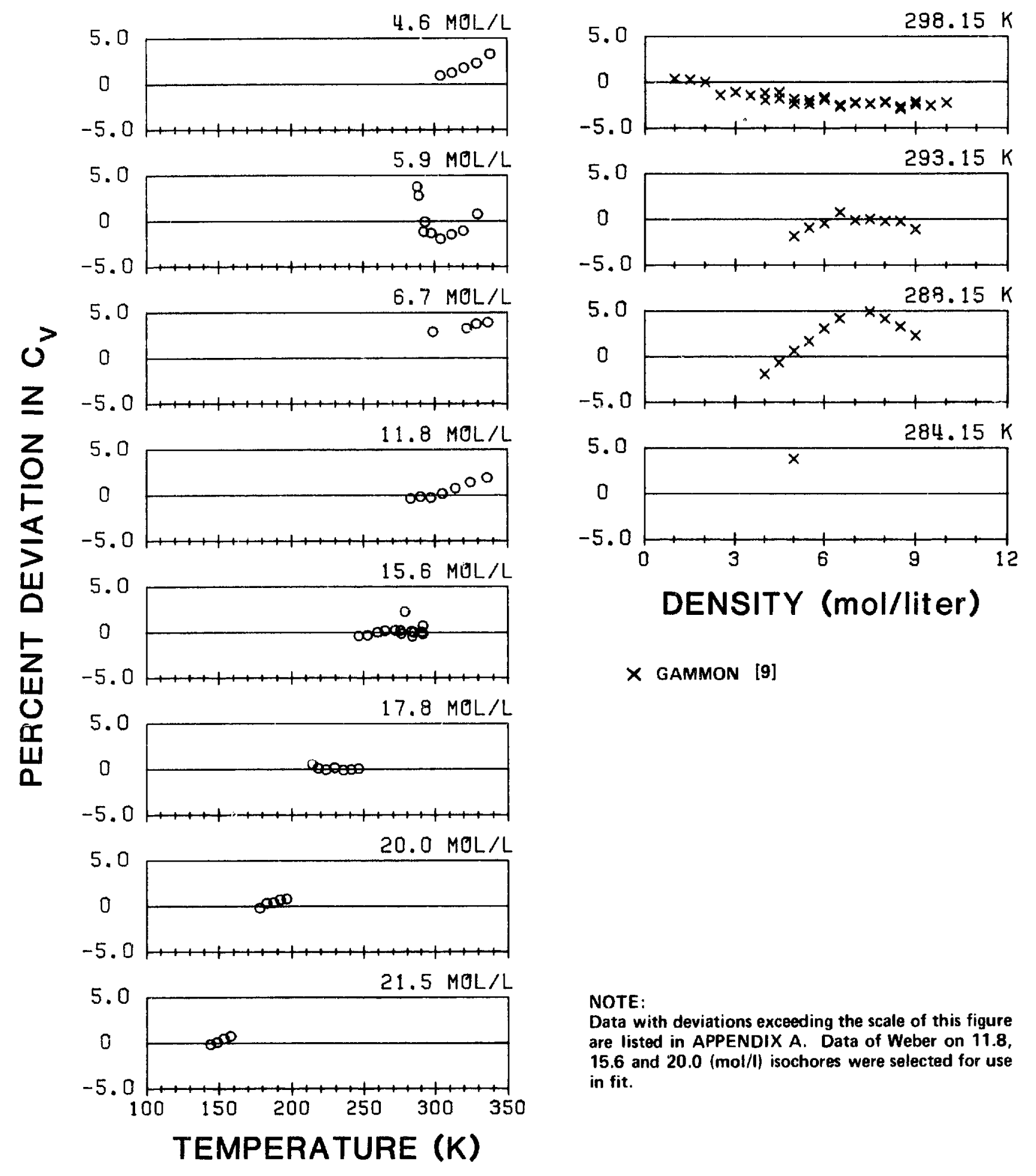

O WEBER [47]

Figure 9. Deviations of Calculated Values of Heat Capacity From Data 


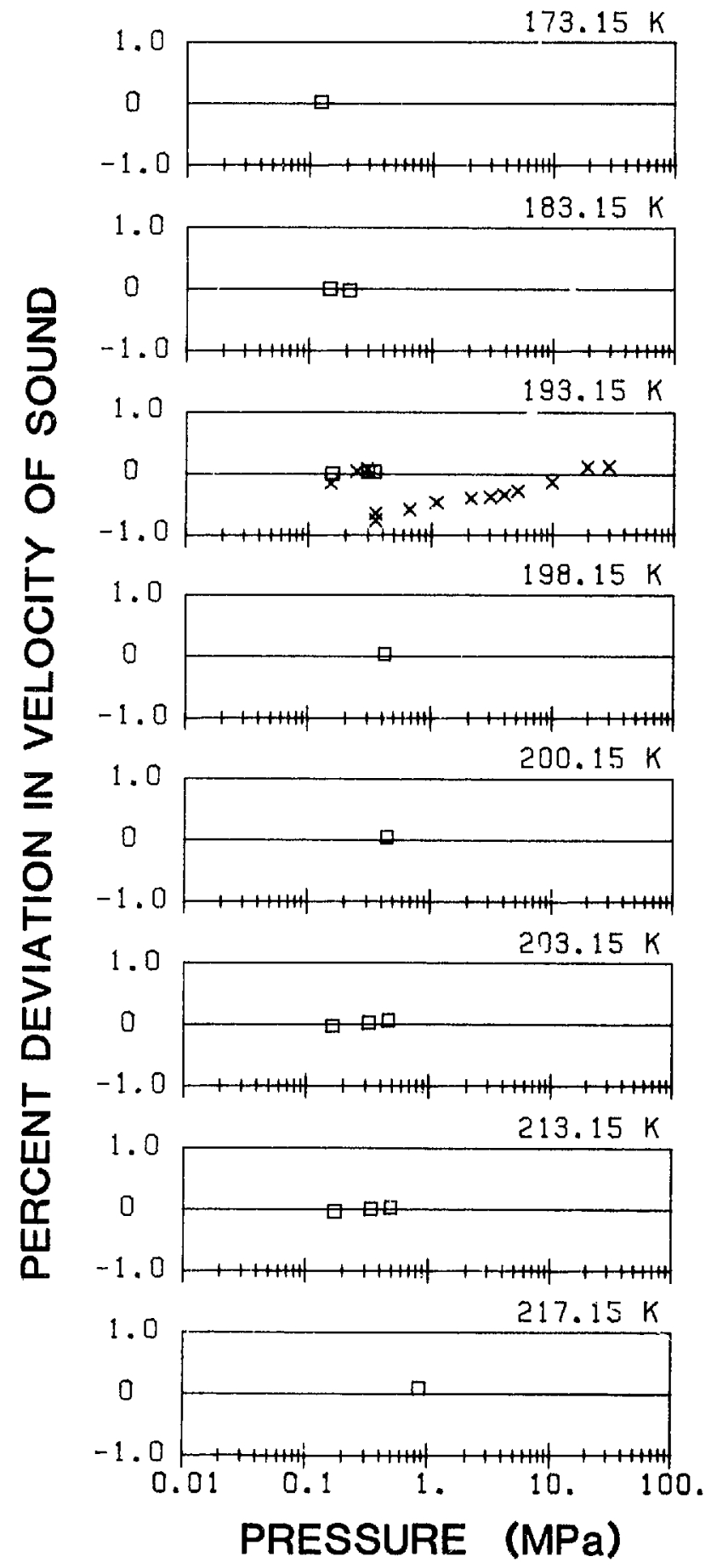

$X$ DREgulyas [7]
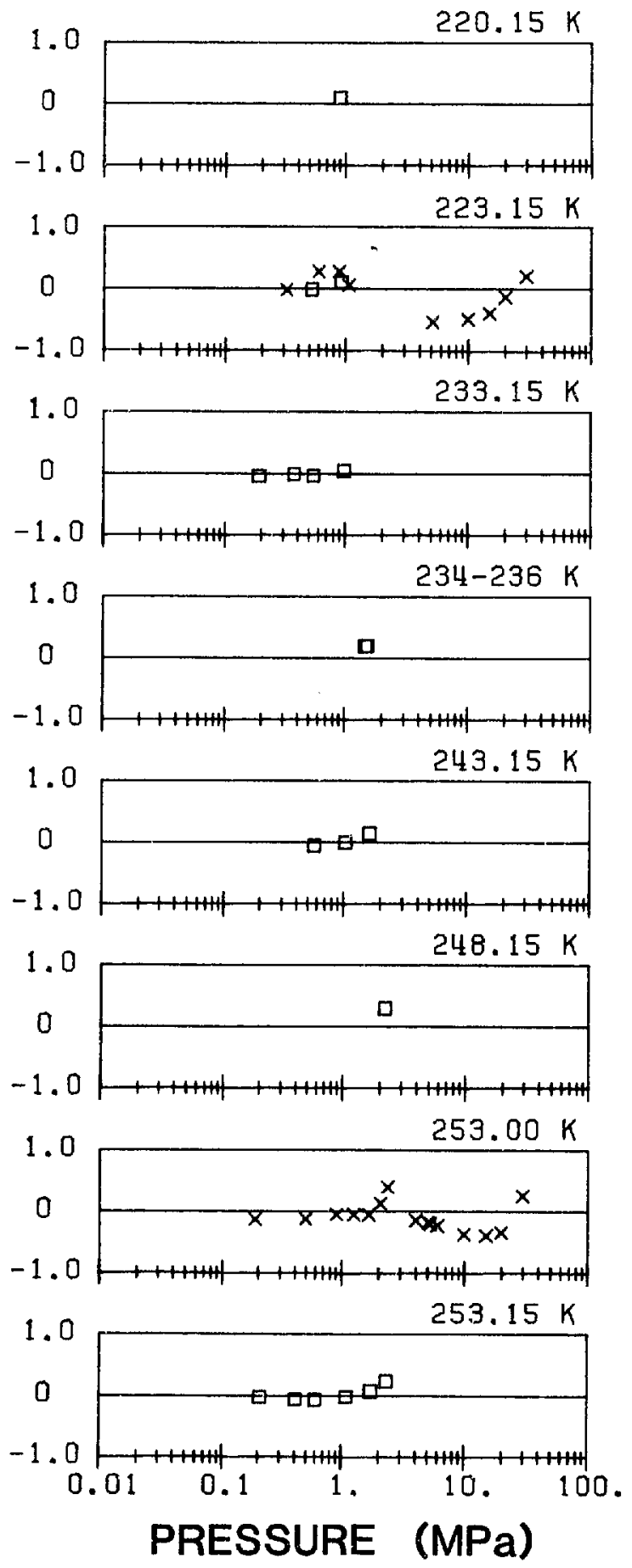

口 GAMMON [9]

Figure 10. Deviations of Calculated Values of Velocity of Sound from Selected Data 


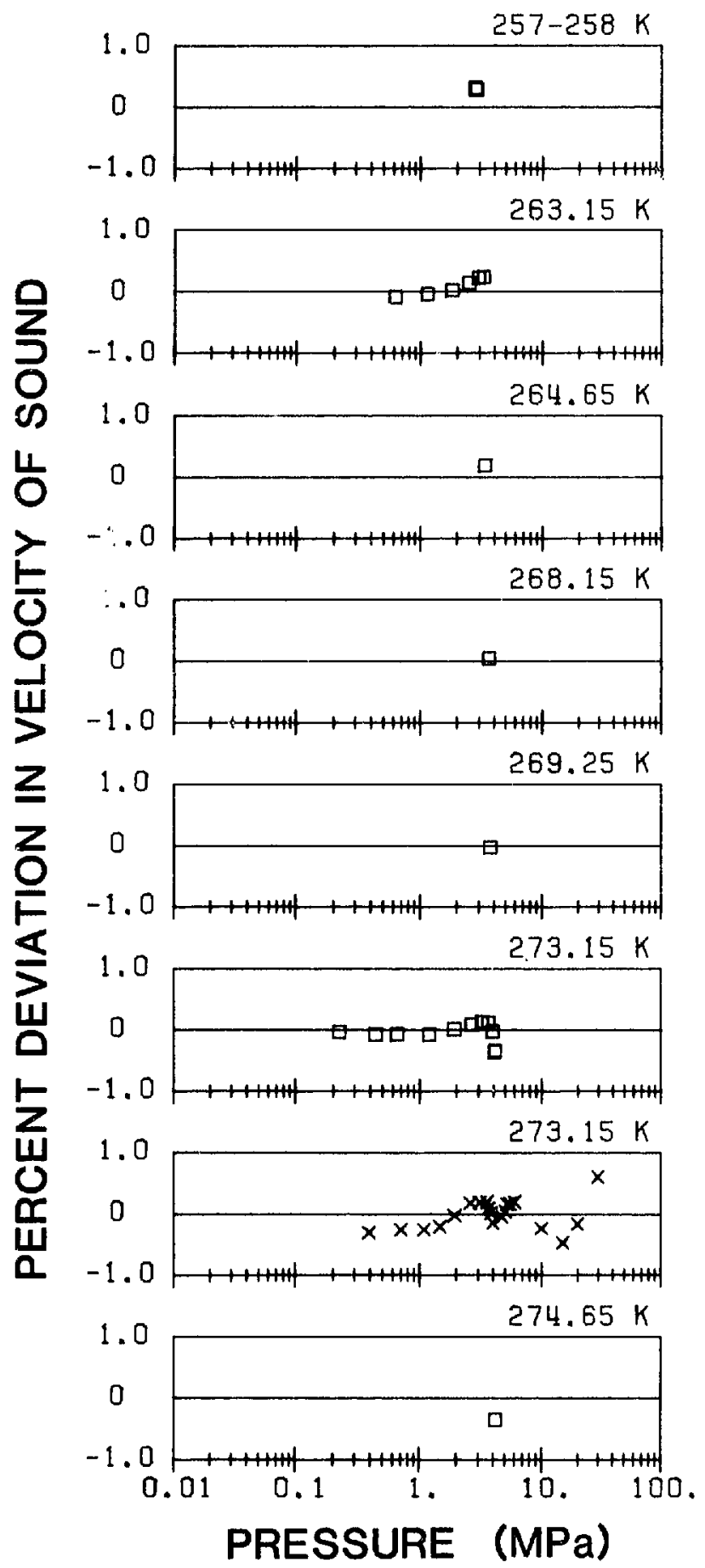

$x$ Dregulyas [7]
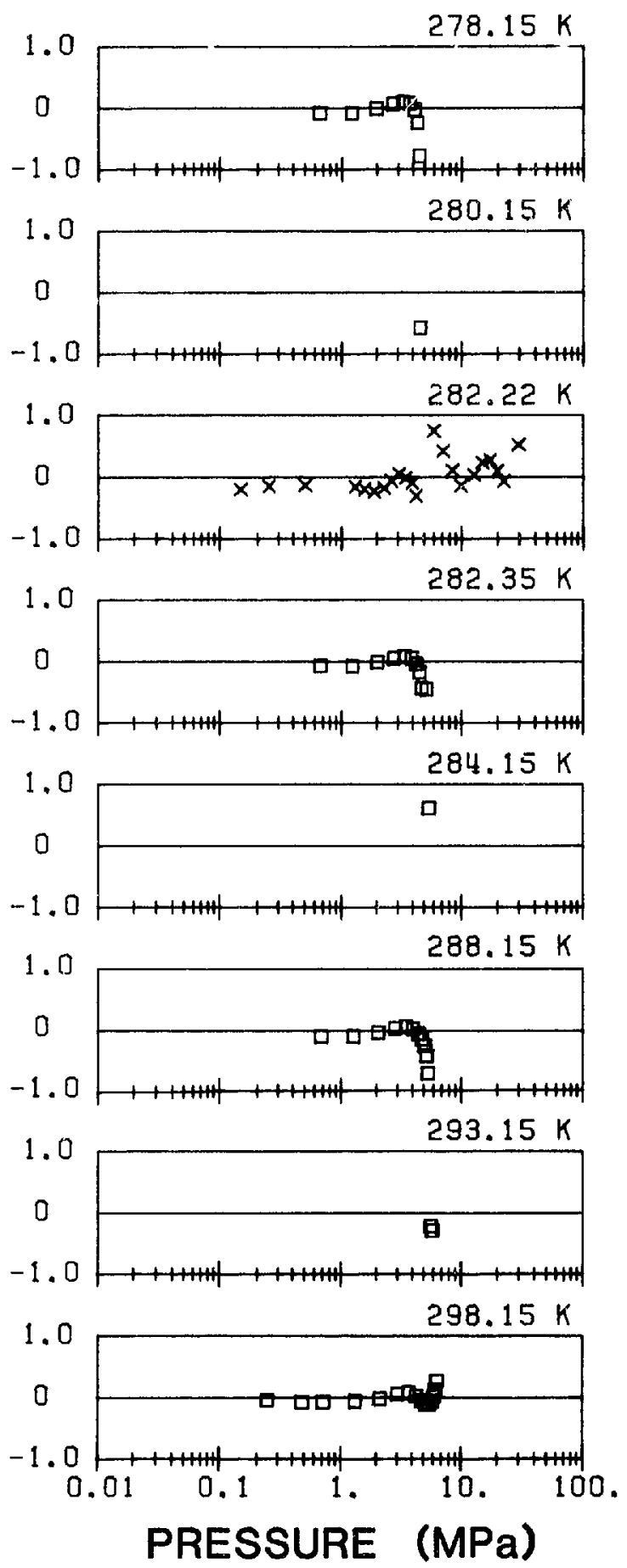

口 GAMMON 19]

Figure 10. Deviations of Calculated Values of Velocity of Sound from Selected Data (Continued) 


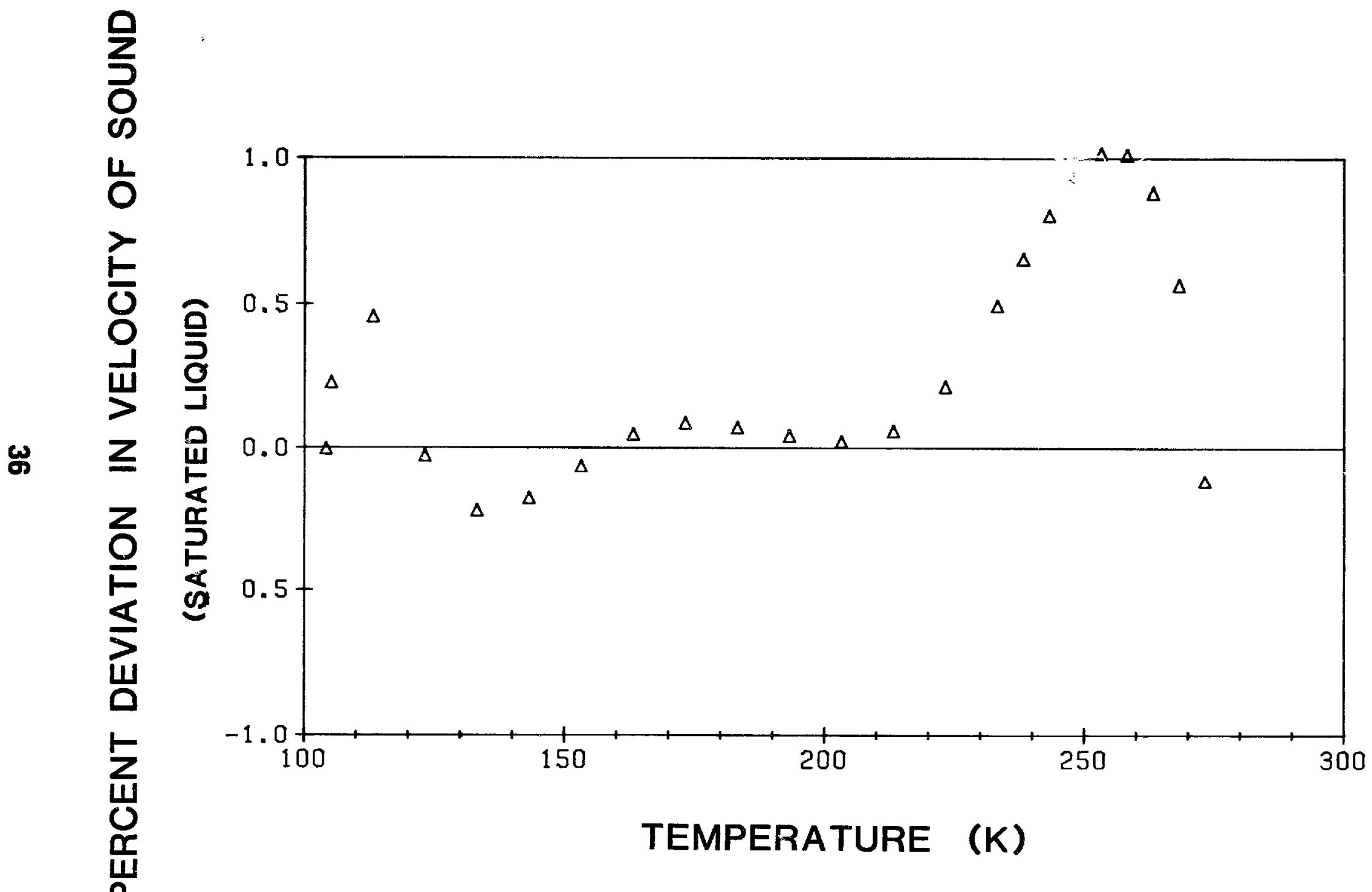

Figure 11. Deviation of Calculated Values of Velocity of Sound from Selected Data for the Saturated Liquid of Gammon [9] 
data of Gammon [9] for the velocity of sound of the saturated liquid used in the fit of the equation of state. Four data points between temperatures of $280 \mathrm{~K}$ and $282.15 \mathrm{~K}$ were excluded from the fit, and one point near $260 \mathrm{~K}$ has a deviation exceeding one percent and is not shown in figure 11. Comparisons to all available single phase velocity of souird data are given in Appendix $A$. Using saturated vapor states determined by extrapolation of the equation of state to the vapor pressure has resulted in some improvement in the comparison to the saturated liquid velocity of sound values of Cammon over saturation values determined by other methods. The resulting improvements did not significantly alter the $P-\rho-T$ representation of this formulation from that of preliminary fits of the P-o-T data alone, and the final values of saturation densities are generally within the estimated accuracy of the measured data of Golovskij and Tsymarnyi [10] and Haynes [15]. These comparisons indicate large discrepancies between the data and values of the velocity of souna calculated from this formulation at and near saturation above $230 \mathrm{~K}$ in both liquid and vapor states. The values calculated using this formulation in this region must be considered unreliable.

Figure 12 shows comparisons between the experimental $C_{p}$ data by Hejmadi and Powers [16] ${ }^{16}$ by Watanabe [45], and by Vashchenko [43] and corresponding calculated values from eq (1). Data points with deviations beyond the scale of figure 12 are also included in table A-2 in Appendix A.

rable 11 gives a comparison among the heats of vaporization calculated using the eq (1), those of Douslin [6], and the data of Kozlov [20]. Other heat of vaporization data, Douslin [6], Egan and Kemp [8], Clusius and Konnertz [5], and Tully and Edmister [41], are included for comparative purposes.

The data from Kozlov [20] are a result of a cooperative effort between this project and the Data Center of the State Service of Standard Reference Data for Urganic Compounds at Kiev in the USSR. This project furnished the laboratory in Kiev with an ultra-pure sample of ethylene; in return, the Kiev laboratory agreed to make heat of vaporization measurements and velocity of sound measurements on that sample and furnish the project with the results prior to their publication. Both the heats of vaporization and velocity of sound data

$\overline{16}$ Data taken as a part of this project. 


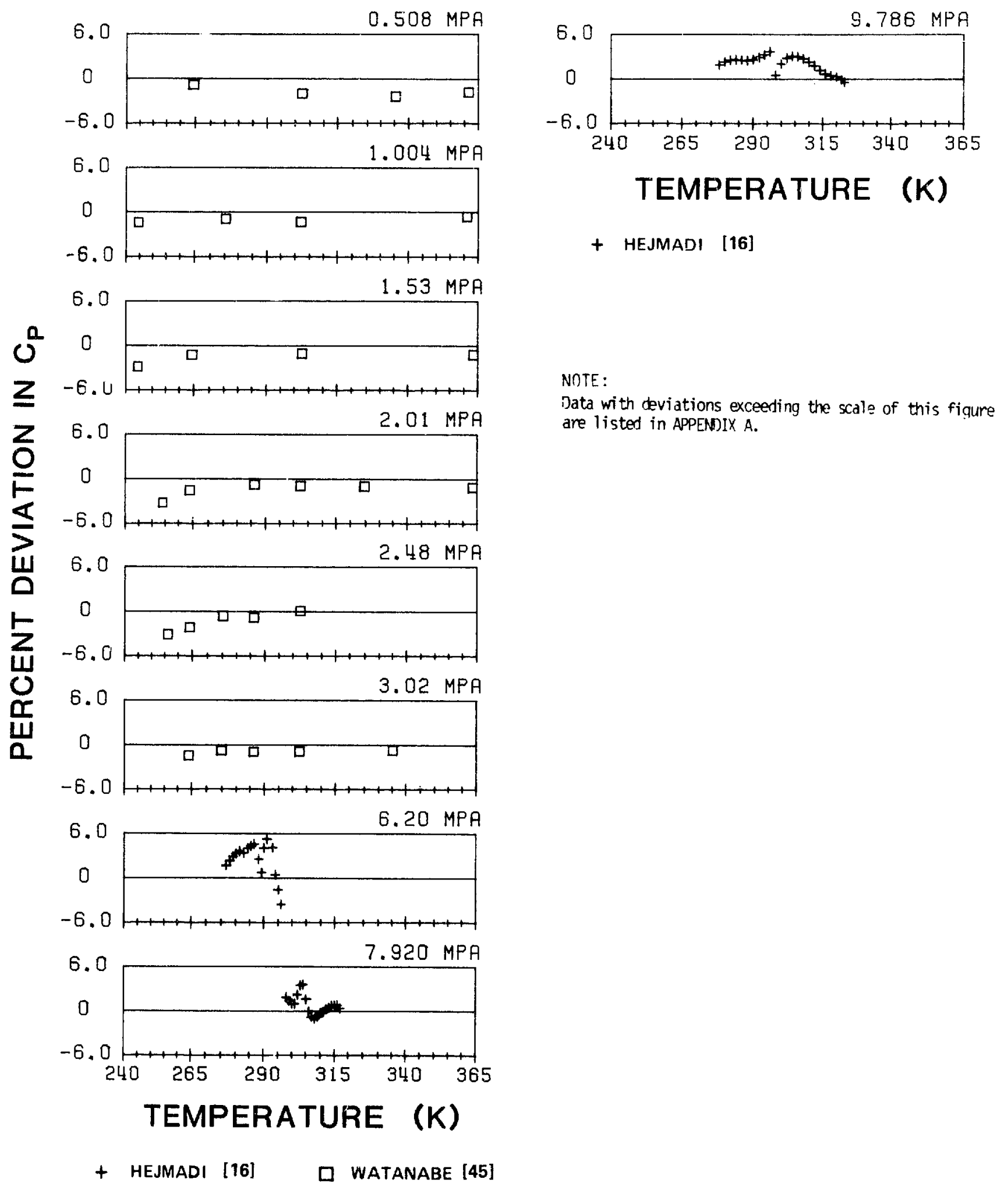

Figure 12. Comparisons of Calculated Values of $C_{P}$ with Data 

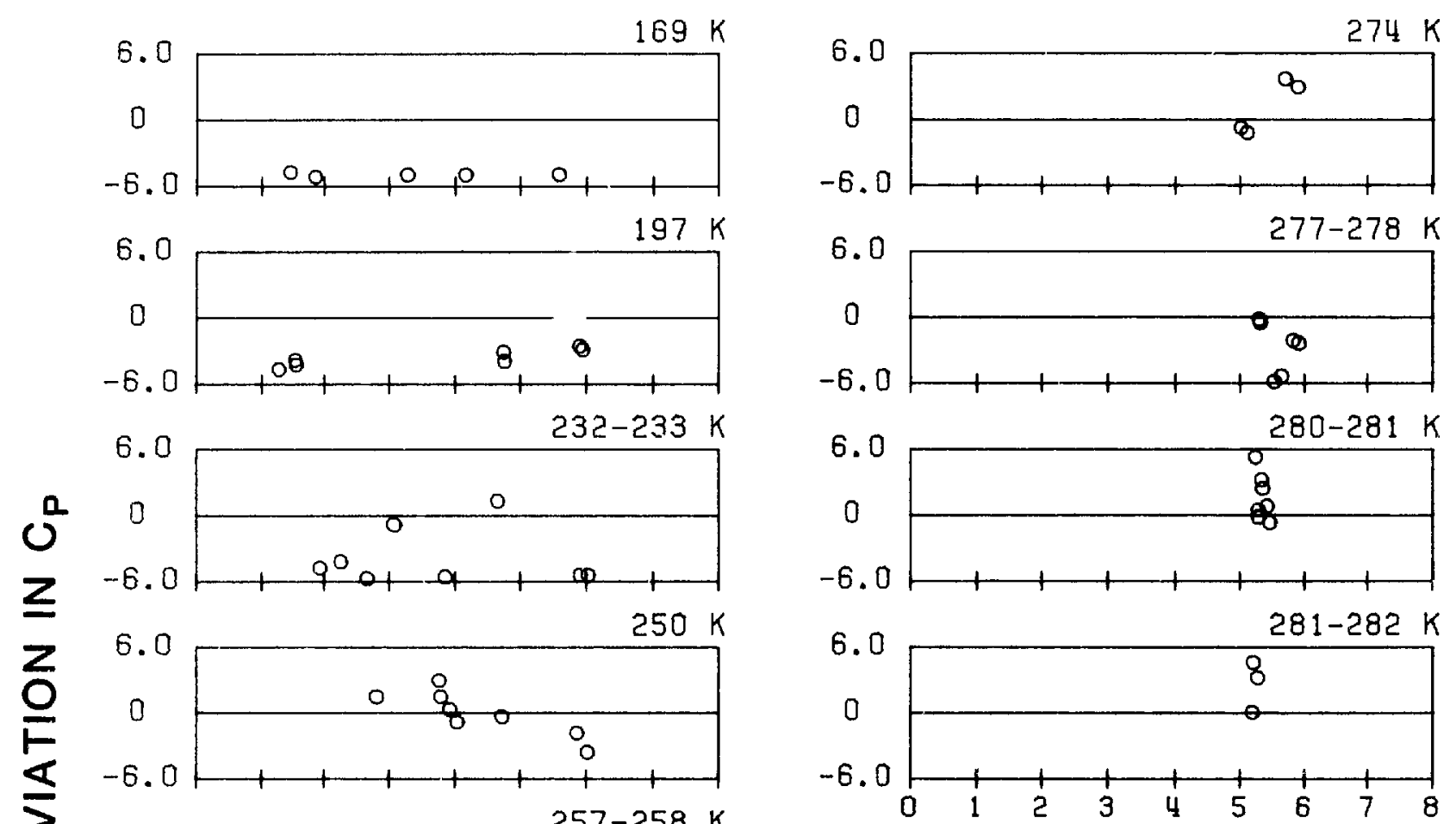

\section{PRESSURE (MPa)}

\section{O VASHCHENKO [42]}

NOTE :

Data with deviations exceeding the scale of this figure are listed in APPENDIX A.
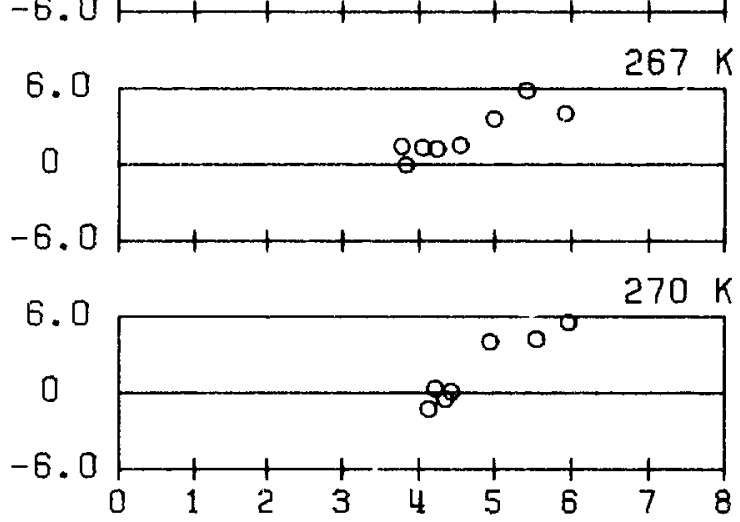

\section{PRESSURE (MPa)}

O VASHCHENKO [42]

Figure 12. Comparisons of Calculated Values of $C_{p}$ with Data (Continued) 
Table 11. Comparison of Calculated and Experimental Data for the Enthalpy of Vaporization

\begin{tabular}{|c|c|c|c|c|}
\hline & $\frac{T}{K}$ & $\frac{\Delta H_{\text {data }}}{\mathrm{J} / \mathrm{mol}^{-1}}$ & $\frac{\Delta H_{\mathrm{eq}}(2)}{\mathrm{J} / \mathrm{mol}^{-1}}$ & $\frac{\Delta \mathrm{data}^{-\Delta H_{\mathrm{eq}}} \text { (2) }}{\mathrm{J} / \mathrm{mol}^{-1}}$ \\
\hline Kozlov $[20]$ & $\begin{array}{l}150.04 \\
159.87 \\
169.95 \\
179.94 \\
190.12 \\
200.15 \\
219.89 \\
229.89 \\
239.61 \\
273.14 \\
273.49\end{array}$ & $\begin{array}{l}14668 \\
14223 \\
13817 \\
13359 \\
12933 \\
12400 \\
11274 \\
10515 \\
9763 \\
5216 \\
5153\end{array}$ & $\begin{array}{l}14288 \\
13918 \\
13516 \\
13090 \\
12622 \\
12121 \\
10976 \\
10286 \\
9515 \\
5211 \\
5134\end{array}$ & $\begin{array}{r}380 \\
308 \\
301 \\
269 \\
311 \\
279 \\
298 \\
229 \\
248 \\
4 \\
19\end{array}$ \\
\hline Dous 1 in and Harrison $[6]^{17}$ & $\begin{array}{l}238.15 \\
243.15 \\
248.15 \\
253.15 \\
258.15 \\
263.15 \\
268.15 \\
273.15\end{array}$ & $\begin{array}{l}9635 \\
9202 \\
8724 \\
8197 \\
7610 \\
6946 \\
6164 \\
5194\end{array}$ & $\begin{array}{l}9638 \\
9203 \\
8727 \\
8201 \\
7615 \\
6948 \\
6168 \\
5209\end{array}$ & $\begin{array}{l}-\quad 2.7 \\
=\quad 0.2 \\
=\quad 2.4 \\
=\quad 3.0 \\
=\quad 4.3 \\
=\quad 1.7 \\
=\quad 3.5 \\
=14.7\end{array}$ \\
\hline Clusius and Konnertz [5] & $\begin{array}{l}143.4 \\
169.5 \\
191.9 \\
209.8 \\
236.0 \\
254.0\end{array}$ & $\begin{array}{r}14327 \\
13394 \\
12523 \\
11661 \\
9678 \\
7854\end{array}$ & $\begin{array}{r}14529 \\
13534 \\
12536 \\
11591 \\
9815 \\
8106\end{array}$ & $\begin{array}{r}-202 \\
-140 \\
-13 \\
70 \\
-137 \\
-252\end{array}$ \\
\hline Egan and Kemp [8] & 169.4 & 13544 & 13539 & 5 \\
\hline Tully and Edmister [41] & $\begin{array}{l}244.1 \\
245.1 \\
270.9\end{array}$ & $\begin{array}{l}9371 \\
9041 \\
5601\end{array}$ & $\begin{array}{l}9115 \\
9022 \\
5670\end{array}$ & $\begin{array}{r}256 \\
19 \\
-\quad 69\end{array}$ \\
\hline
\end{tabular}

17 Data were derived by the authors from their PVT measurements. 
have been receivea from the USSR. As shown in table 11, the heats of vaporization from Kozlov [20] do not agree with the present correlation and are believed to be incorrect. These heats of vaporization were not used in the fit of eq (1). The velocity of sound data of Dregulyas and Stavtzev [7] are in good agreement with those of Cammon [9] and proved to be of considerable value in the correlation as they provided information in the compressed liquid region where no other velocity of sound measurements exist. The velocity of sound data of Dregulyas and Stavtzev [7] were used in the fit of eq (1).

\section{Estiliated Accuracy of the Equation of State}

The equation of state presented here may be used to calculate properties of ethylene for liquid and vapor states from the triple point temperature to $450 \mathrm{~K}$ with pressures to $40 \mathrm{MPa}$. Based upon the deviations of calculated values from data values, the accuracy of the equation of state is estimated as \pm 0.20 percent in density for most of both 1 iquid and vapor regions of the surface. At the highest temperatures, $i . e .$, above $400 \mathrm{~K}$, the uncertainty is estimated as \pm 0.3 percent in density. The equation is not valid near the critical point and should not be used for states within 30 percent of the critical density at temperatures within 5 percent of the critical temperature. The formulation should be considered accurate to within \pm 2.5 percent for the calculation of heat capacity values, and within about \pm 1 percent for the calculation of velocity of sound except in the critical region, and at (and near) the saturated liquid and saturated vapor states where the deviations may be larger. A possible additional source of error when calculating thermodynamic properties using any equation of state, no matter how accurate that equation of state might be, is the error resulting from errors in the input variables. This error is especially important in the case of custody transfer when the equation of state together with a measured pressure and temperature is used as a means of determining the total mass. Figure 13, reproduced from Thomas, et al. [37], illustrates the resulting errors in density due to errors in the input pressure and temperature. The chart has been constructed for an assumed error in measurement of temperature of $0.5 \mathrm{~K}$ and an assumed error in pressure of 0.5 percent. Except for the liquid region where the errors in density are almost entirely the result of the assumed error in temperature, the resulting error in density as shown in figure 13, is divided about equally between the assumed errirs in pressure and temperature. The chart may be used for other assumed errors in pressure and temperature by a linear 


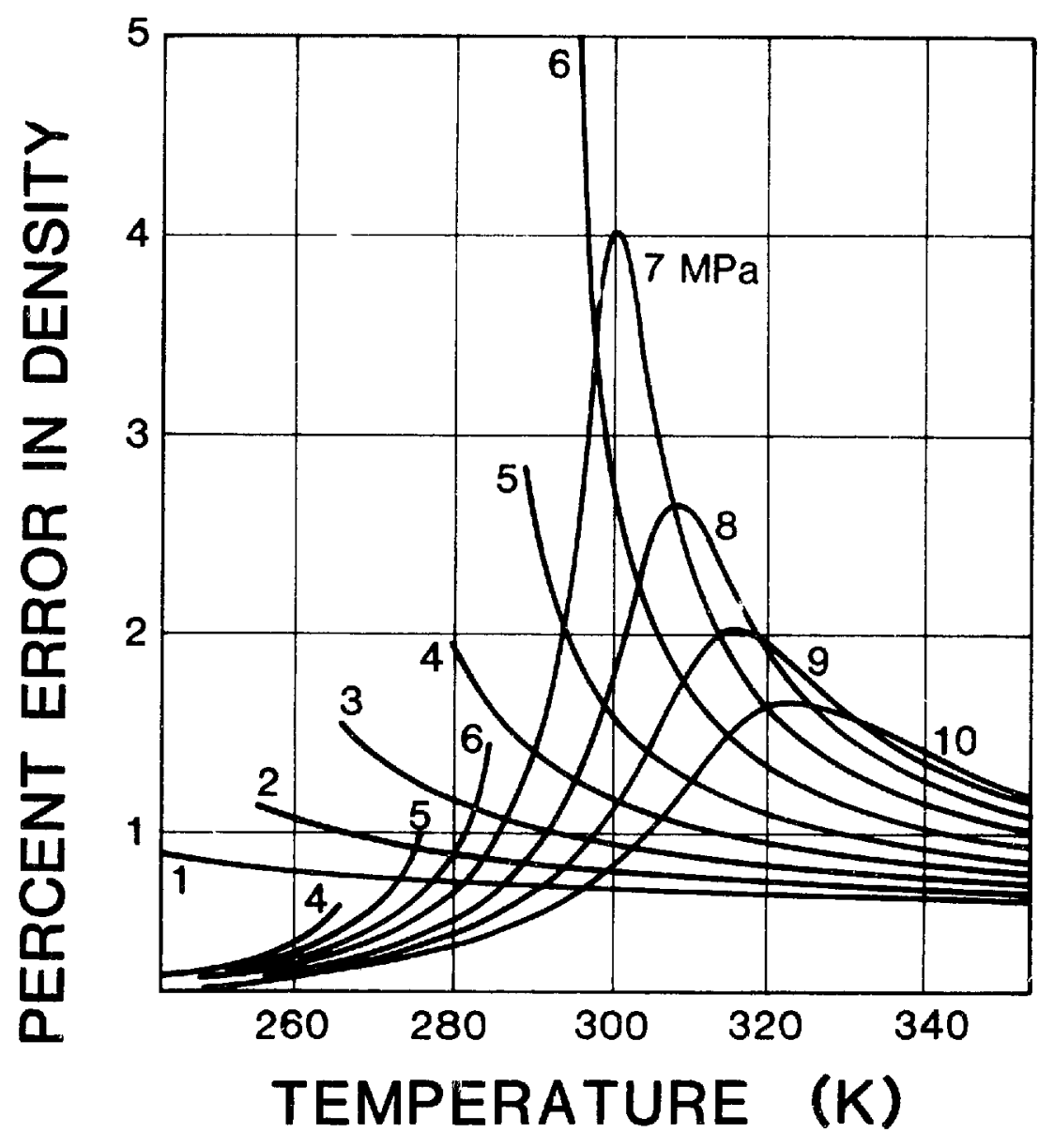

Figure 13. Accuracy of the Equation of State for Assumed Errors in Temperature and Pressure (0.5 K, 0.5\% P) from Thomas et. al [37] 
translation; for exainple, if the assumed errors in pressure and temperature are doubled, the resulting error in density is doubled. Figure 13 is intended as a general guide, and for a more accurate assessiment of these errors the equation

$$
\Delta \rho=\left(\frac{\partial \rho}{\partial T}\right)_{p} \Delta T+\left(\frac{\partial \rho}{\partial P}\right)_{T} \Delta P
$$

should be used. The $\left(\frac{\partial \rho}{\partial T}\right)_{P}$ and $\left(\frac{\partial \rho}{\partial P}\right)_{T}$ may be obtained from the tables in Appendix 3 by

$$
\left(\frac{\partial \rho}{\partial T}\right)_{P}=-\left(\frac{\partial P}{\partial T}\right)_{\rho}\left(\frac{\partial P}{\partial \rho}\right)_{T}^{-1}
$$

and

$$
\left(\frac{\partial \rho}{\partial P}\right)_{T}=\left(\frac{\partial P}{\partial \rho}\right)_{T}^{-1}
$$

\section{Conclusion}

At the beginning of this project, the goal was to provide a mathematical model of the thermodynamic surface of ethylene and new property tables more accurate than those of prior formulations. It was expected that these results would be accurate to within \pm 0.1 percent in density and within \pm 1 percent in derived properties such as $C_{v}$. In addition to the general accuracy statement above, the model was to include the critical region by using a switching function as the critical region is encountered. This would accomplish the merger of the critical region model of Hastings, et al. [14] with this formulation. The merger of the two equations was not accomplished and the reader who wishes to make calculations in the critical region ( $\rho_{c} \pm .3 \rho_{c}$ for temperature of $T_{c} \pm .05 T_{c}$ ) should use the equation of state in Hastings, et a1. [14].

Although a substantial improvenent has been made over the equations and tables available six years ago, the accuracy goa? has probably not been achieved. Unfortunately the two major sets of P-p-T daca used in the development of the model, i.e., Straty [33] and Dous? in and Harrison [6], disagree by as much as 0.2 percent in regions common to the two data sets. A good deal of effort, including additional experimental work and alternate methods of data analysis, was expended 
in trying to resolve this disagreement without success. At the start of this work, the discrepancy between the two data sets was as large as 0.25 percent. This disagreement was resolved in part by Straty when he verified that some adsorption had taken place in his early experiments. He built a new cell, and repeated the experiment. The data from the second experiment agreed more closely with those of Douslin and Harrison [6], but a 0.2 percent disagreement persists. Impurities do not seem to be a possible cause of the discrepancy as ultra-pure samples were used in both Straty's and Douslin's experiments. Straty repeated some of his experiments with ethylene which had substantial amounts of known impurities, with very little change in the results.

A similar situation exists in the $c_{v}$ data of Weber [47], but in this case the disagreement is in a single source. There are apparent inconsistencies anong the various isochores. As a consequence, only a portion of the data were used in determining the coefficients for the equation of state as outlined in section 4.

In view of the above mentioned discrepancies, and others, it was decided that until these discrepancies are resolved either by experimentation or by additional data analysis, further work on the development of the equation of state is not warranted. Any improvements in the model using the available data would require new methods of correlation or new techniques of datd analysis. 
[1] Angus, S., Armstrong, B., de Reuck, K. M., Featherstone, W. and Gibson, M. R., International Thermodynamic Tables of the Fluid State, Ethylene, 1972, International Union of Pure and Applied Chemistry, Division of Physical Chemistry, Commission on Thermodynamics and Thermochemistry, Thermodynamic Tables Project, Butterworths, London (1974).

[2] Barieau, R. E., Analytical expressions for the zero pressure thermodynamic properties of nitrogen gas including corrections for the latest values of the atomic constants and the new carbon-12 atomic weight scale, J. Phys. Chem. 69, 495 (1965).

[3] Bigeleisen, J., Fuks, S., Ribnikar, S. V. and Yato, Y., Vapor pressures of the isotopic ethylenes. $V$. Solid and liquid ethylene- $d_{1}$, ethylene- $d_{2}$ (cis, trans, and gem;, ethylene- $d_{3}$, and ethylene- $d_{4}, J$. Chem. Phys. 66 (4) (Feb 1977).

[4] Chao, J. and Zwolinski, B. J., Ideal gas thermodynamic properties of ethylene and propylene, J. Phys. Chem. Ref. Data 4 (1), 251 (1975).

[5] Clusius, K. and Konnertz, F., Results of low temperature research: VI . Calorimetric measurements of heat of vaporization of oxygen at normal pressure and of ethylene and propylene below and above atmospheric pressure, Z. Naturf. 4a, 117 (1949).

[6] Douslin, D. R. and Harrison, R. H., Pressure, volume, temperature relations of ethylene, J. Chem. Thermodynamics $\underline{8}, 301$ (1976).

[7] Dregulyas, E. K. and Stavtzev, A. F., Sound velocity in liquid and gaseous ethylene in subcritical region, private communication (Sep 1979).

[8] Egan, C. J. and Kemp, J. D., Ethylene, the heat capacity from $15 \mathrm{~K}$ to the boiling point. The heats of fusion and vaporization. The vapor pressure of the liquid. The entropy from thermal measurements compared with the entropy from spectroscopic data, American Chem. Soc: 59, 1264 (1937).

[9] Gammon, B. E., Velocity of sound in ethylene, presented at the Advisory Committee Meeting of the Joint Industry-Government Ethylene Project, Boulder, Colorado (Dec. 6, 1978).

[10] Golovskii, E. A. and Tsymarnyi, V. A., Density of fluid ethylene on phase equilibrium curves, Izv. Vyssh. Uchebn. Zaved., Neft Gaz 20 (1), 81 (1977).

[11] Golovskii, E. A., Mitsevich, E. P. and Tsymarnyi, V. A., Experimental determination of the density of liquid ethylene in the temperature interval 104-220 $\mathrm{K}$ and at pressures up to $600 \mathrm{bar}$, Izv. Vyssh. Uchebn. Zaved., Neft Gaz 19 (12), 72 (1976).

[12] Golovskii, E. A., Zagoruchenko, V. A. and Tsymarnyi, V. A., Experimental study of the compressibility of ethylene up to a pressure of 2000 bar, Izv. Vyssh. Uchebn. Zaved., Neft Gas 16 (9), 73 (1973). 
[13] Hastings, J.R. and Levelt Sengers, J. M. H., Vapor pressure, critical pressure, and critical isochore of ethylene, in Proceedings 7 th Symposium on Thermophysical Properties, Cezairliyan, A., editor, ASME, New York, 794 (1977).

[14] Hastings, J. R., Levelt Sengers, J.M. H. and Balfour, F. W., The critical-region equation of state of ethene and the effect of small impurities, J. Chem. Thermodynamics 12, 1009 (1980).

[15] Haynes, W. M., Measurements of the orthobaric liquid densities of argon $(100-120 \mathrm{~K})$ and ethylene $(105-200 \mathrm{~K})$, Cryogenics 18 (10), 621 (Uct 1978).

[16] Hejmadi, A. V. and Powers, J. E., A calorimetric investigation of ethylene, private communication, Thermal Properties of Fluids Laboratory, Department of Chemical Engineering, University of Michigan, Ann Arbor 'Jul 1979).

[17] Herget, K. M., J. Chem. Phys. 8, 437-542 (1940), reported in Vashchenko, et al. (1972), Ref. 43 below.

[18] Jacobsen, R. T., The thermodynamic properties of nitrogen from $65 \mathrm{~K}$ to $2000 \mathrm{~K}$ with pressures to 10,000 atmospheres, Ph.D. Dissertation, Washington State University, Pullman (1972).

[19] Jacobsen, R. T., Stewart, R. B. and Mui, P. K., The Fundamental Equation of State, Center for Applied Thermodynamic Studies Report No. 78-3, University of Idaho, Moscow (Apr 1976).

[20] Kozlov, A. D., Experimental investigation of the heats of vaporization of ethylene, private communication (Oct 1979).

[21] Lee, R. C., Compressibility factors and virial coefficients for methane, ethylene, and their mixtures, using an isothermal expansion ratio apparatus, Ph.D. Thesis, Uklahoma State University, Stillwater, Oklahoma, (May 1969).

[22] Levelt-Sengers, J. M. H. and Hastings, J.R., Equation of state of ethylene vapor between 223 and $273 \mathrm{~K}$ by the Burnett method, private communication, Thermophysics Division, Natior: 1 Bureau of Standards, Washington, DC (March 3, 1981).

[23] Meh1, J. B. and Moldover, M. R., Precision measurements with a spherical resoriator: $\mathrm{Ar}$ and $\mathrm{C}_{2} \mathrm{H}_{4}, \mathrm{~J}$. Chem. Phys. 74 (7) (Apr 1981).

[24] Menes, F., Dorfmuller, T. and Bigeleisen, J., Molal volumes of the isotopic homologs of ethylene, J. Chem. Phys. 53, No. 7, 2869-2878 (1970).

[25] Michels, A. and Geldermans, M., Isotherms of ethylene up to 3000 atmospheres between 0 and $150 \mathrm{C}$, Physica $\underline{9}$ (10), 967 (Dec 1942).

[26] Michels, A. and Wassenaar, T., The vapor pressure of ethylene, Physica 16, $221(1950)$. 
[27] Michels, A., DeGruyter, J. and Niesen, F., Isotherms of ethylene between 0 and $150 \mathrm{C}$ and at pressures from 20 to $270 \mathrm{~atm}$, Physica $\underline{3}$ (5), 346 (May 1936).

[28] Moldover, M., private communication, National Bureau of Standards, Washington, DC. (1980).

[29] Mui, P. K., Jacobsen, R. T. and Stewart, R. B., A Fundamental Equation of State for Argon, Nitrogen and Uxygen, Center for Applied Thermodynamic Studies, Report No. 78-5, University of Idaho, Moscow (Nov 1978).

[30] Prasad, D. H. L., Pressure-volume-temperature relations of hydrogen, ethylene and their mixtures, Ph.D. Thesis, Indian Institute of Science, Bangalore, India (Oct 1977).

[31] Saville, G., private communication, Thermodynamic Tables Project Centre, Imperial College of Science and Technology, Dept. of Chemistry, London, England (Mar 1976).

[32] Soldatenko, Yu. A. and Dregulyas, E. K., in Ref. 43, English translation, pp. $72-75$.

[33] Straty, G. C., PVT of compressed fluid ethene, J. Chem. Thermodynamics 12, $709(1980)$.

[34] Stull, D. R. and Prophet, H., Project Directors, JANAF Thermochemical Tables, Second Edition, Office of Standard Reference Data, NSRDS Publication No. 37, U.S. Department of Commerce, Washington, DC (1971).

[35] Terres, V. E., Jahn, W. and Reissmann, H., Zur kenntnis der bestimmung von adiabatischen exponenten leicht siedender kohlenwasserstoffe bei verschiedenen drucken und temperaturen durch messung der ultraschallgeschwindigkeiten, Zeitschrift fuer Chemie 38 $(9 / 10), 129$ (May 1957).

[36] Thomas, W. and Zander, $M_{\text {., }}$ Thermische zustandsgroessen von aethylen, $Z$. Angew. Phys. 20, 417 (1966).

[37] Thomas, W., Zander, M., Quietzsch, G. and Hartmann, H., Dichte des aethylens fuer temperaturen von $-30 \mathrm{C}$ bis $80 \mathrm{C}$ bei drucken bis zu 100 bar, Herausgeber Hoechst $A G$, Frankfurt/M-Hoechst (1976).

[38] Thomas, W., Zander, M., Quietzsch, G. and Schuchmann, H., Dichte des aethylens im einphasengebiet fuer temperaturen von $30 \mathrm{C}$ bis $75 \mathrm{C}$ bei drucken bis zu 100 bar, Farbwerke Hoechst AG, Frankfurt/M-Hoechst (1972).

[39] Tickner, A. W. and Lossing, F. P., The measurement of low vapor pressures by means of a mass spectrometer, J. Phys. and Colloid Chem. 55, 733 (1951).

[40] Trappeniers, N. J., Wassenaar, T. and Wolkers, G. J., Isotherms and thermodynamic properties of ethylene at temperatures between 0 and $150 \mathrm{C}$ and at densities up to 500 amagat, Physia 82A, 305 (1976). 
[41] Tully, P. C. and Edmister, W. C., Isobaric integral heats of vaporization for methane-ethylene system, Am. Inst. Chem. Eng. J. 13, 155 (1967).

[42] Vashchenko, D. M., Isochoric heat capacity of ethylene and propylene, private communication (1971).

[43] Vashchenko, D. M., Voinov, Yu. F., Voityuk, B. V., Dregulyas, E. K., Kolomiets, A. Ya., Labinov, S. D., Morozov, A. A., Neduzhi, I. A., (Principal Author), Provotar, V. P., Soldatenko, Yu. A., Storozhenko, E. I. and Khmara, Yu. I., Thermodynamic and transport properties of ethylene and propylene, (translated from the Russian as published by the State Committee of Standards of the Soviet Ministry, IJ.S.S.R., State Office of Standards and Reference Data, Series: Monograph No.8, 1971), Uffice of Standard Reference Data, National Bureau of Standards, U.S. Department of Commerce, Washington, DC (Jun 1972).

[44] Voityuk, B. V. and Labinov, S. D., in Ref. 43, pp. 30-42, (English translation pp. 39-46).

[45] Watanabe, K., private cormunication, Keio University, Yokohama, Japan (Jan 1980).

[46] Waxman, M. and Davis, H. A., State-of-the-art determination of the second virial coefficient of ethylene for temperatures from 0 to $175 \mathrm{C}$, Advances in Chemistry Series, Equations of State in Engineering and Research 182, 285 (1979).

[47] Weber, L. A., Measurements of the Specific Heat, $C_{v}$, of Ethylene (to be published). 
Symbol

$T$

$p$

$\rho$

$v$

U

G

H

$\mathrm{S}$

$\mathrm{C}_{\mathrm{p}}$

$c_{v}$

$W$

L

$B(T)$

$(\partial P / \partial \rho)_{T}$

$(\partial P / \partial T)_{\rho}$

Superscript

0

\section{Subscripts}

0

c

$\sigma$

tp

eqn

data

$n \mathrm{bp}$

satv

sat 1

tpv

$t p 1$
Physical Quantity

Temperature

Pressure

Density

specific volume

Internal energy

Gibbs function (Gibbs free energy)

Enthalpy

Entropy

Isobaric heat capacity

Isochoric heat capacity

Velocity of sound

Latent heat

Second virial coefficient

Isotherm derivative

Isochore derivative

Ideal gas property

Reference state property

Critical point property

Property at saturation

Triple point property

Calculated using an equation

Experimental value

Normal boiling point

Saturated vapor

Saturated liquid

Triple point (vapor)

Triple point (liquid)

Molecular weight of ethylene, 28.054.

Gas constant, $R=8.31434 \mathrm{~J} /(\mathrm{mol} \cdot \mathrm{K})$.
Unit Symbol

$\mathrm{K}$

$\mathrm{MPa}$

$\mathrm{mol} / \mathrm{dm}^{3}$

$\mathrm{dm}^{3} / \mathrm{mo}^{2}$

$\mathrm{J} / \mathrm{mol}$

$\mathrm{J} / \mathrm{mol}$

$\mathrm{J} / \mathrm{mo} 1$

$\mathrm{J} /(\mathrm{mol} \cdot \mathrm{K})$

$\mathrm{J} /(\mathrm{mol} \cdot \mathrm{K})$

$\mathrm{J} /(\mathrm{mol} \cdot \mathrm{K})$

$\mathrm{m} / \mathrm{s}$

$\mathrm{J} / \mathrm{mol}$

$\mathrm{dm}^{3} / \mathrm{mol}$

$\mathrm{dm}^{3} / \mathrm{MPa} / \mathrm{mol}$

$\mathrm{MPa} / \mathrm{K}$ 


\begin{tabular}{lll} 
Symbol & \multicolumn{1}{c}{ Fixed Points } & \multicolumn{1}{c}{ Value } \\
\hline$T_{c}$ & Critical temperature & $282.3428 \mathrm{~K}$ \\
$P_{c}$ & Critical pressure & $5.0403 \mathrm{MPa}$ \\
$\rho_{c}$ & Critical density & $7.6340 \mathrm{~mol} / \mathrm{dm}^{3}$ \\
$T_{t p}$ & Triple point temperature & $103.986 \mathrm{~K}$ \\
$P_{t p}$ & Triple point pressure & $1.213 \times 10^{-4} \mathrm{MPa}$ \\
$\rho_{t p v}$ & Triple point density (vapor) & $1.42546 \times 10^{-4} \mathrm{~mol} / \mathrm{dm}^{3}$ \\
$\rho_{t p l}$ & Triple point density (liquid) & $23.343 \mathrm{~mol} / \mathrm{dm}^{3}$ \\
$T_{n b t}$ & Normal boiling point temperature & $169.41 \mathrm{~K}$ \\
$P_{n b p}$ & Normal boiling point pressure & $0.101325 \mathrm{MPa}$ \\
$\rho_{n b p v}$ & Normal boiling density (vapor) & $0.07445 \mathrm{~mol} / \mathrm{dm}^{3}$ \\
$\rho_{n b p l}$ & Normal boiling density (liquid) & $20.24 \mathrm{~mol} / \mathrm{dm}^{3}$
\end{tabular}


APPENDIX A. Comparisons to Available Data Sets Including Those Used in the Determination of the Coefficients of the Equation of State (1). 


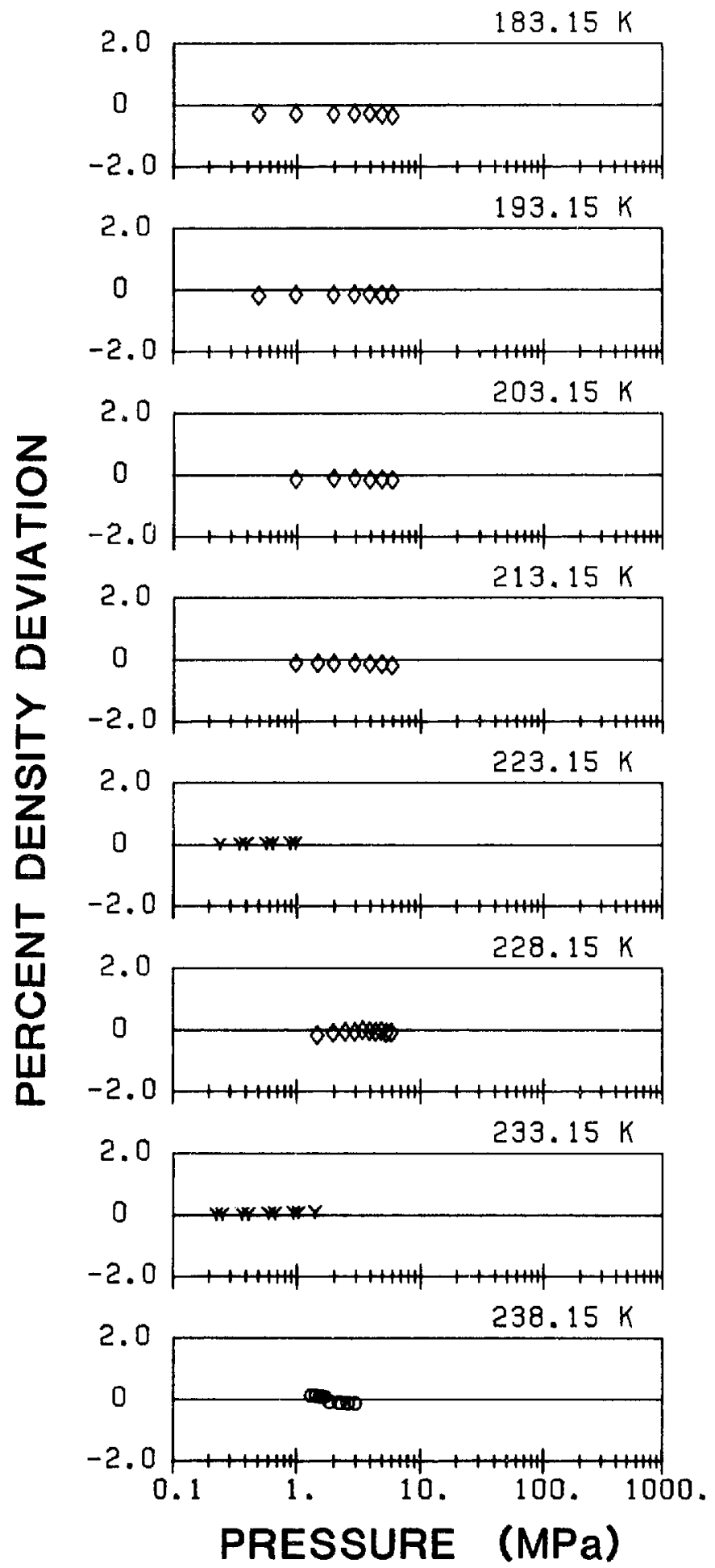

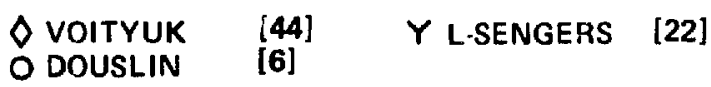
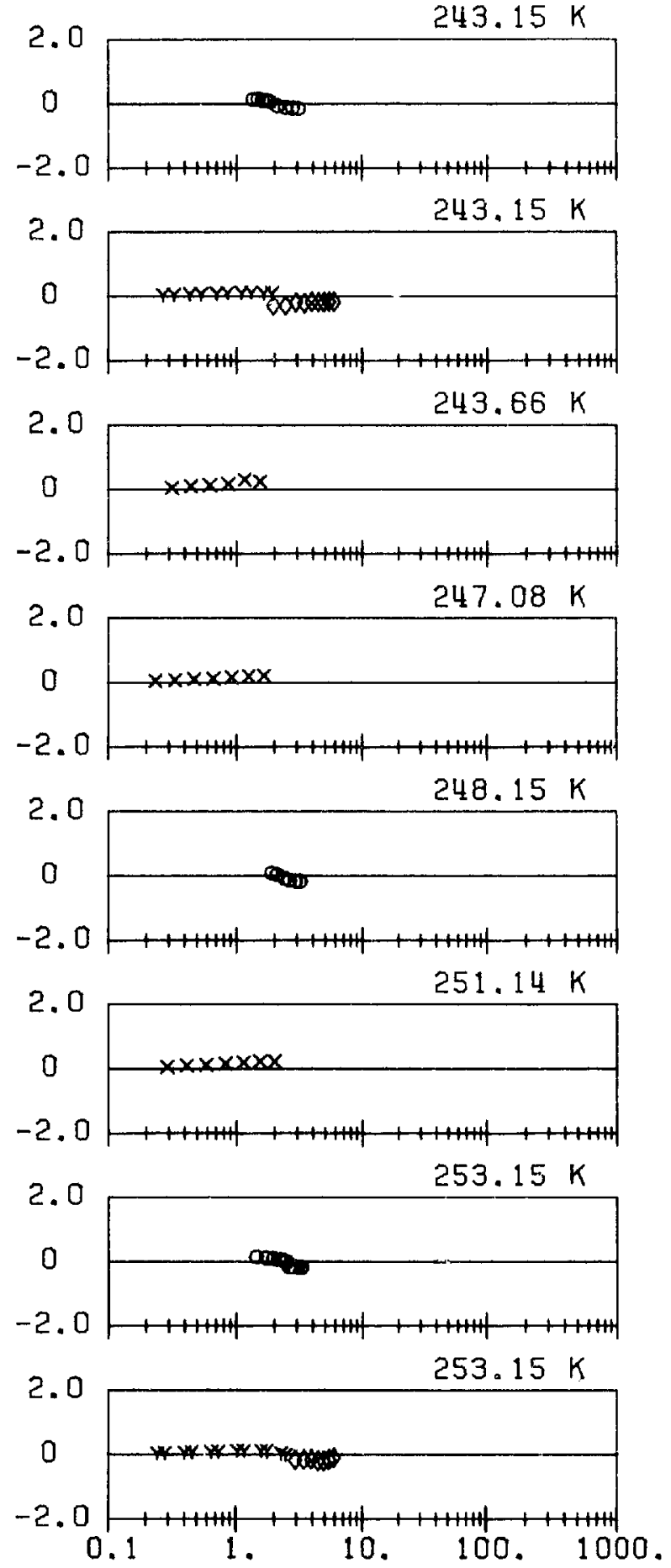

PRESSURE (MPa)

$\begin{array}{llll}\bigcirc \text { VOITYUK } & {[44]} & \times \text { SAVILLE } & {[31]} \\ O \text { DOUSLIN } & {[6]} & Y \text { L-SENGERS } & {[22]}\end{array}$




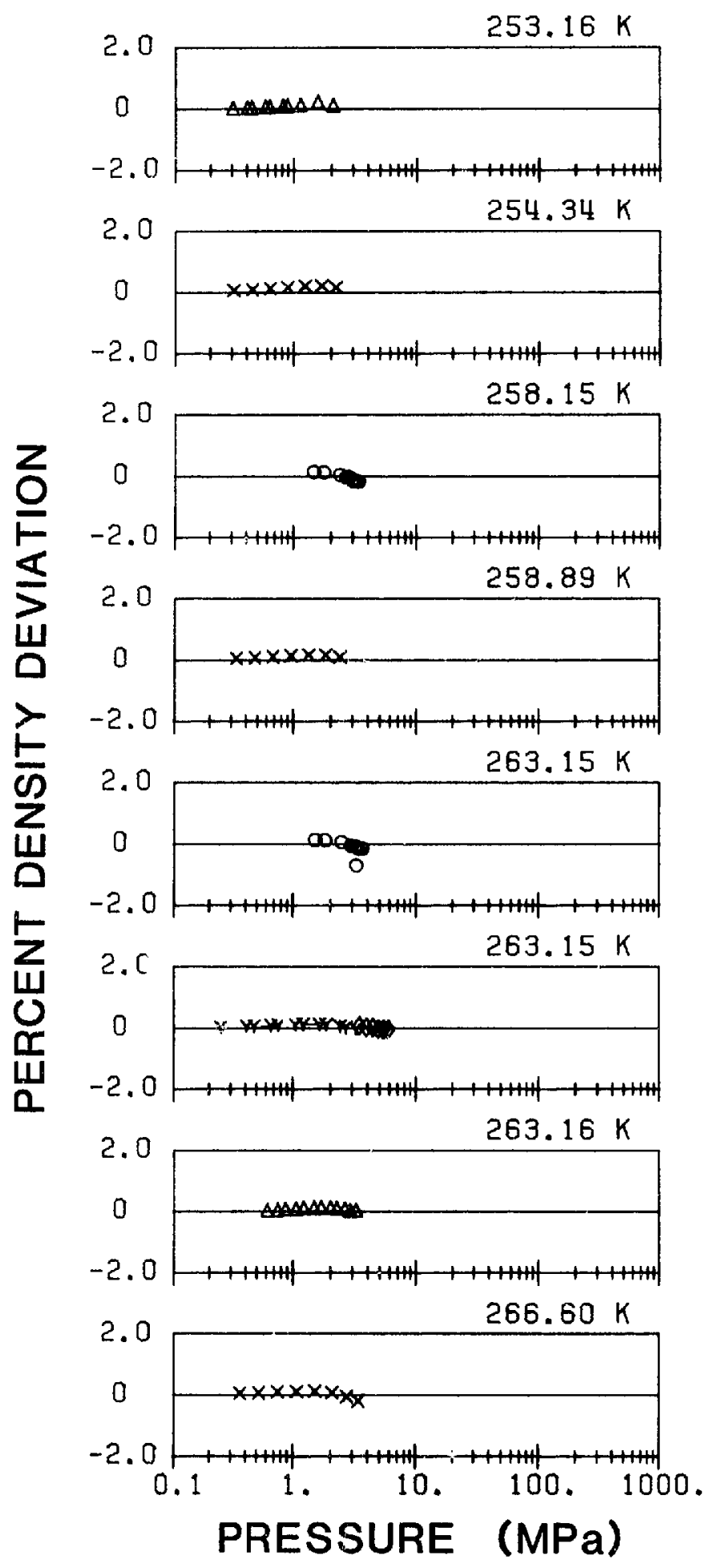

$\begin{array}{llll}\bigcirc \text { VOITYUK } & {[44]} & \text { Y L-SENGERS } & {[22]} \\ \text { O DOUSLIN } & {[6]} & \Delta \text { THOMAS } & {[38]} \\ \times \text { SAVILLE } & {[31]} & & \end{array}$

$\begin{array}{lllr}\bigcirc \text { VOITYUK } & {[44]} & \square \text { THOMAS } & {[36]} \\ O \text { DOUSLIN } & {[6]} & \triangle \text { THOMAS } & {[38]} \\ X \text { SAVILLE } & {[31]} & + \text { TRAPPENIERS [40] }\end{array}$

Figure A-1. Comparisons to PVT Data (Continued) 


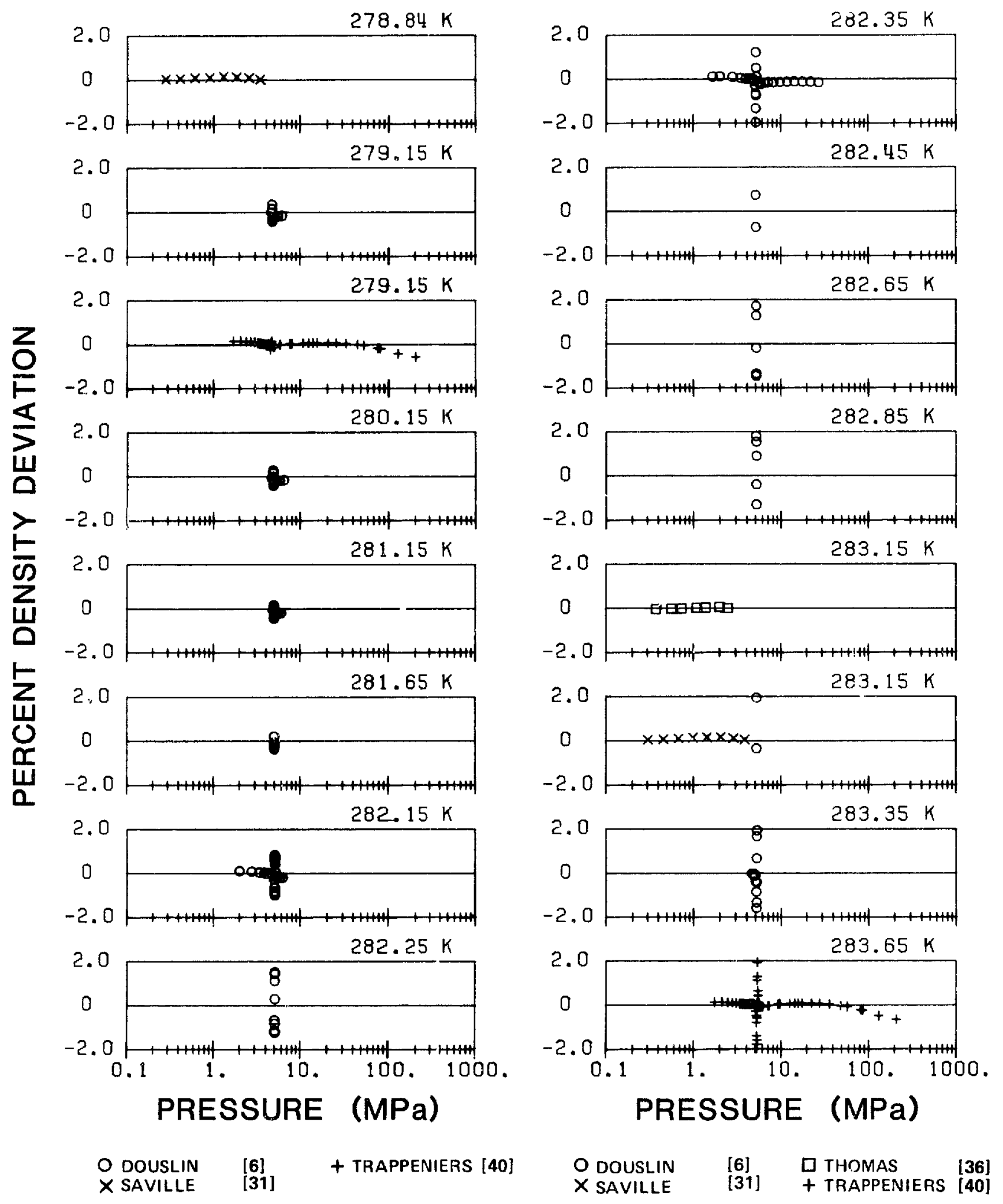

Figure A-1. Comparisons to PVT Data (Continued) 

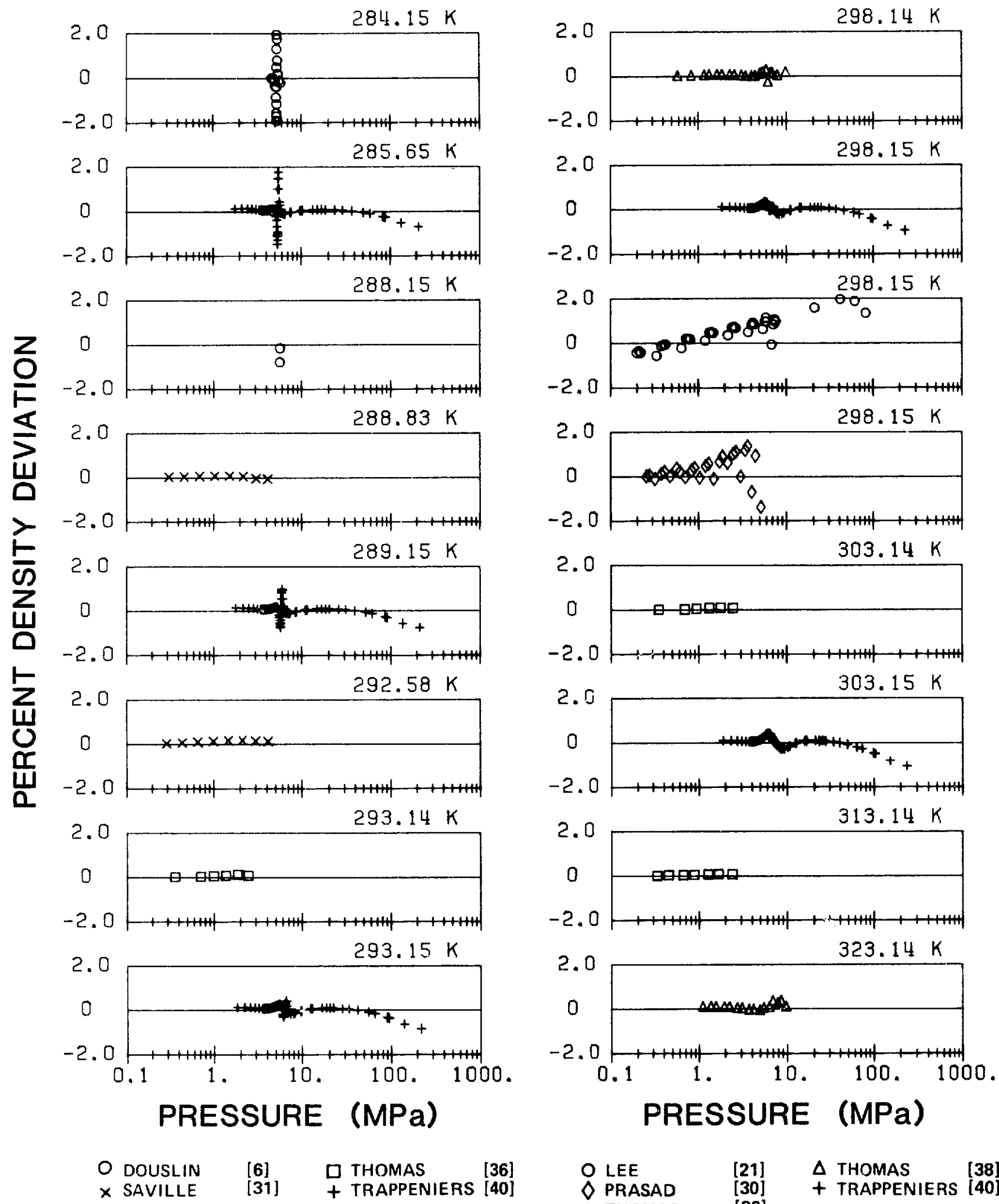

\section{PRESSURE (MPa)}

\begin{tabular}{|c|c|c|}
\hline $\begin{array}{l}\text { O LEE } \\
\diamond \text { PRASAD } \\
\end{array}$ & $\begin{array}{l}{[21]} \\
{[30]} \\
{[36]}\end{array}$ & $\begin{array}{l}\triangle \text { THOMAS } \\
+ \text { TRAPPENIERS }\end{array}$ \\
\hline
\end{tabular}

Figure A-1. Comparisons to PVT Data (Continued) 


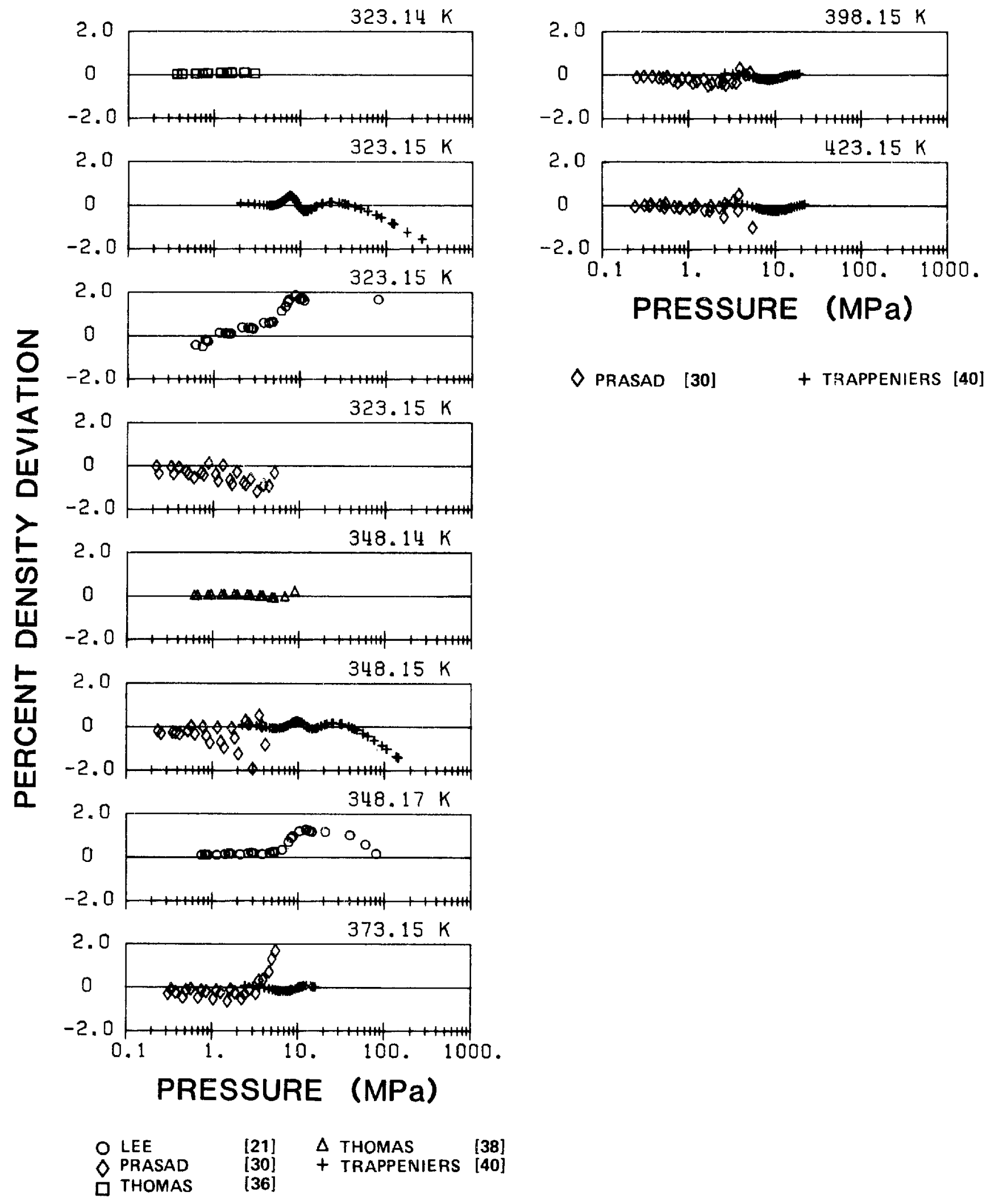

Figure A-1. Comparisons to PVT Data (Continued) 


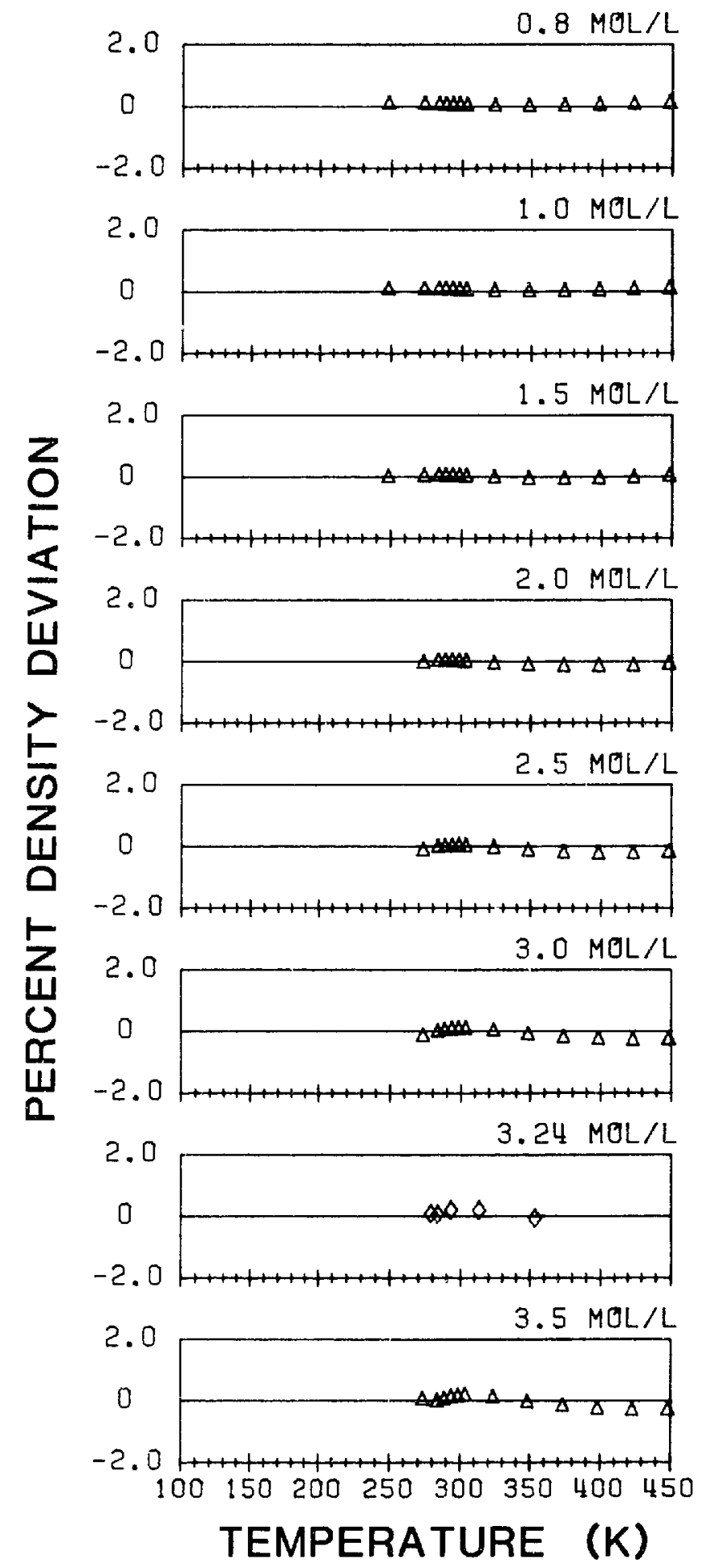

$\triangle$ THOMAS [37] $\triangle$ DOUSLIN [6]
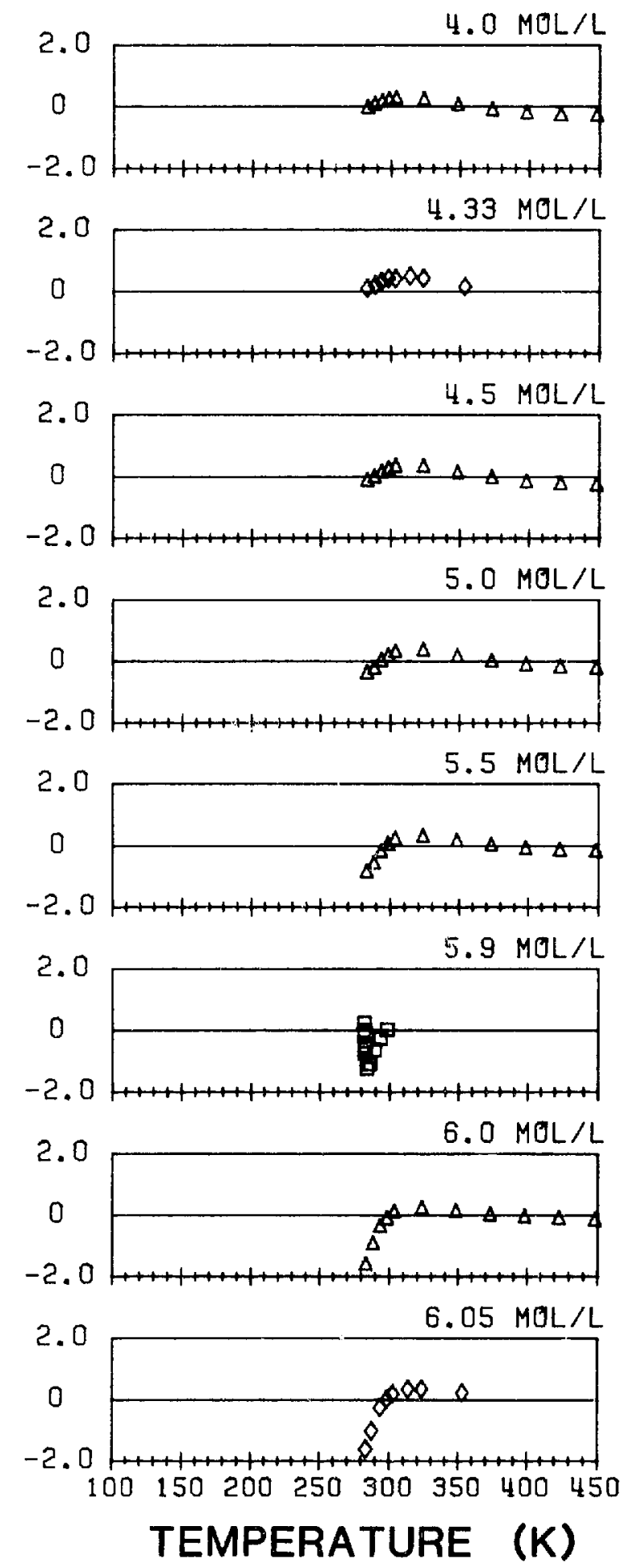

$\begin{array}{ll}\diamond \text { THOMAS } & {[37]} \\ \square \text { HASTINGS } & {[14]}\end{array} \quad \Delta$ DOUSLIN $[6]$

Figure A-1. Comparisons to PVT Data (Continued) 

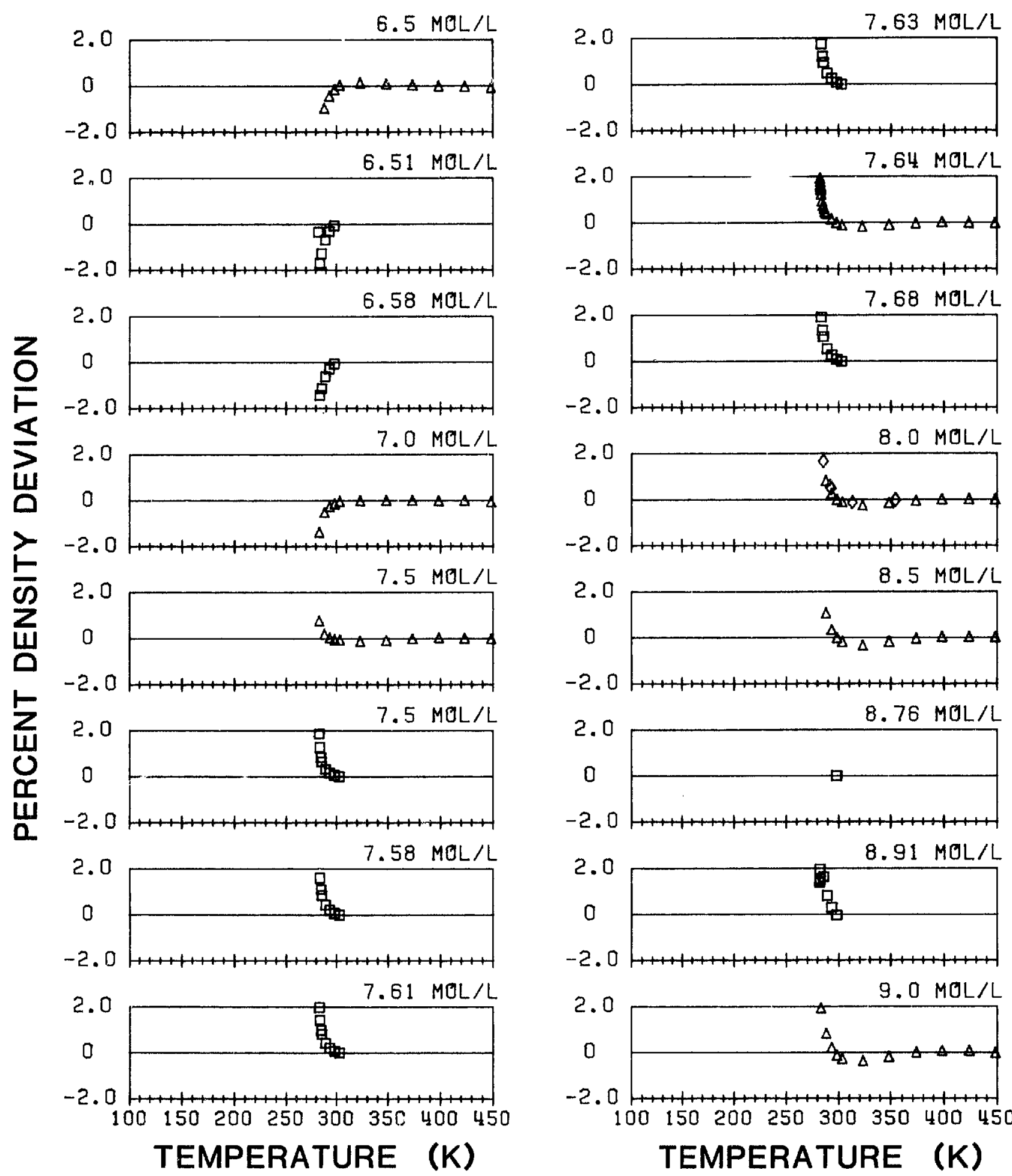

HASTINGS [14] $\triangle$ DOUSLIN [6]

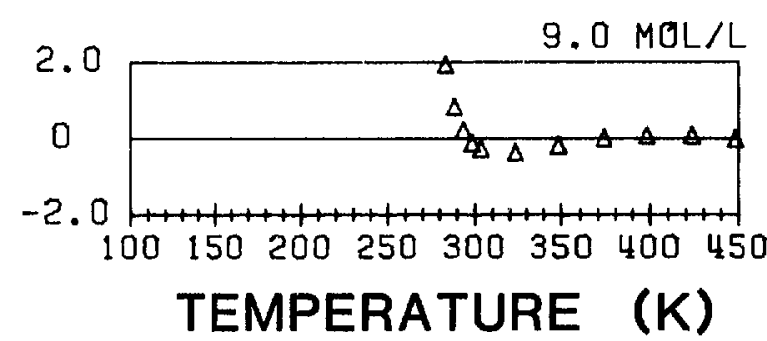

$\begin{array}{lll}\diamond & \text { THOMAS } & {[37]} \\ \square & \text { HASTINGS } & {[14]}\end{array} \quad \Delta$ DOUSLIN

[6]

Figure A-1. Comparisons to PVT Data (Continued) 


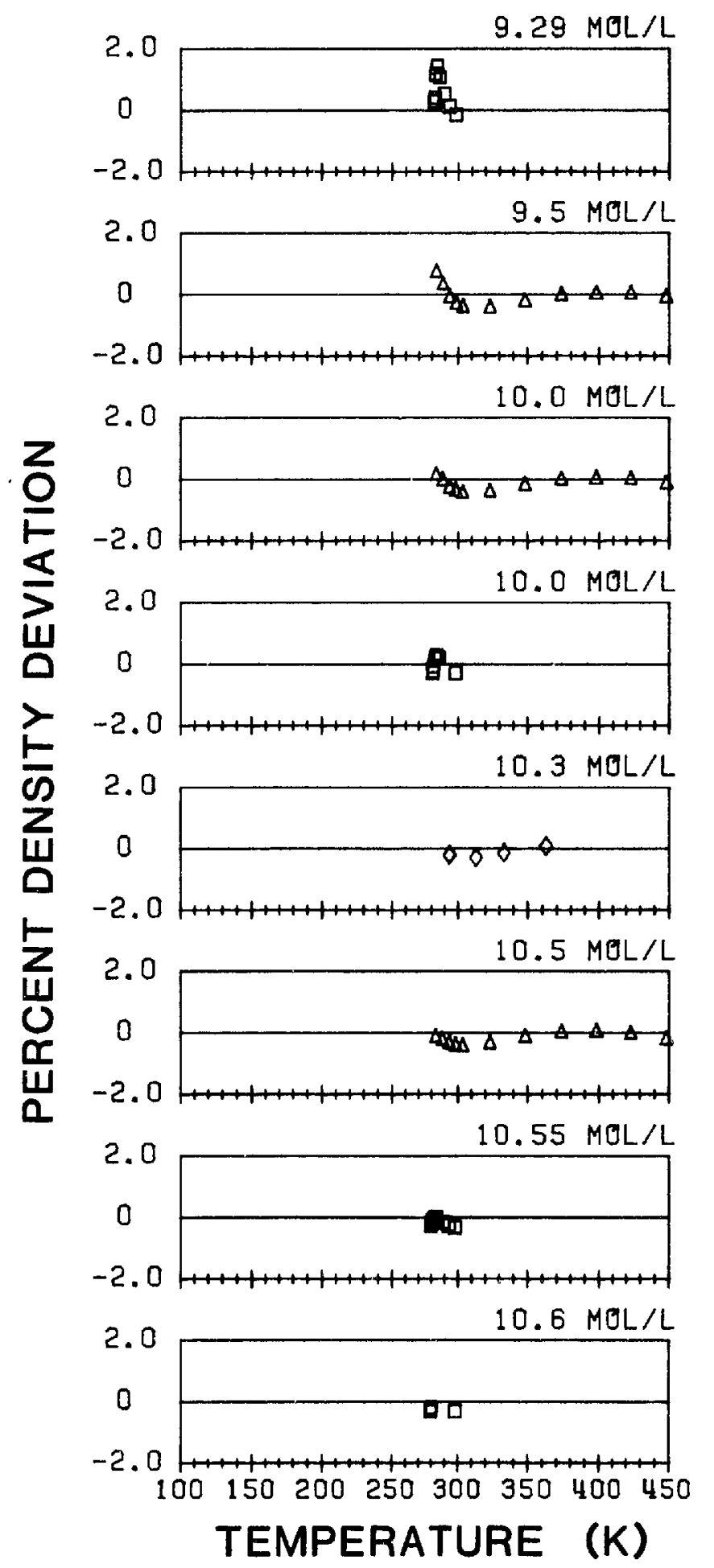

$\begin{array}{lll}\diamond & \text { THOMAS } & {[37]}\end{array} \quad \Delta$ DOUSLIN [6]
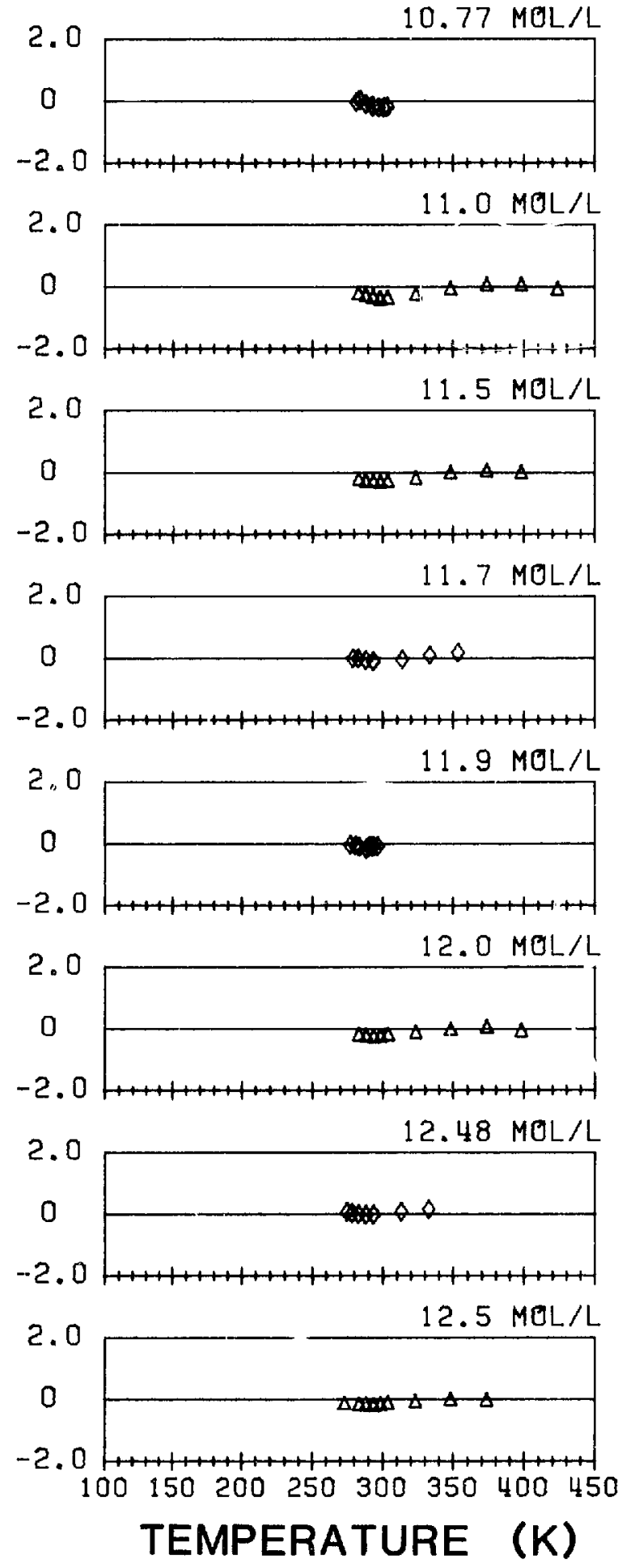

$\checkmark$ THOMAS [37] $\triangle$ DOUSLIN [6]

Figure A-1. Comparisons to PVT Data (Continued) 

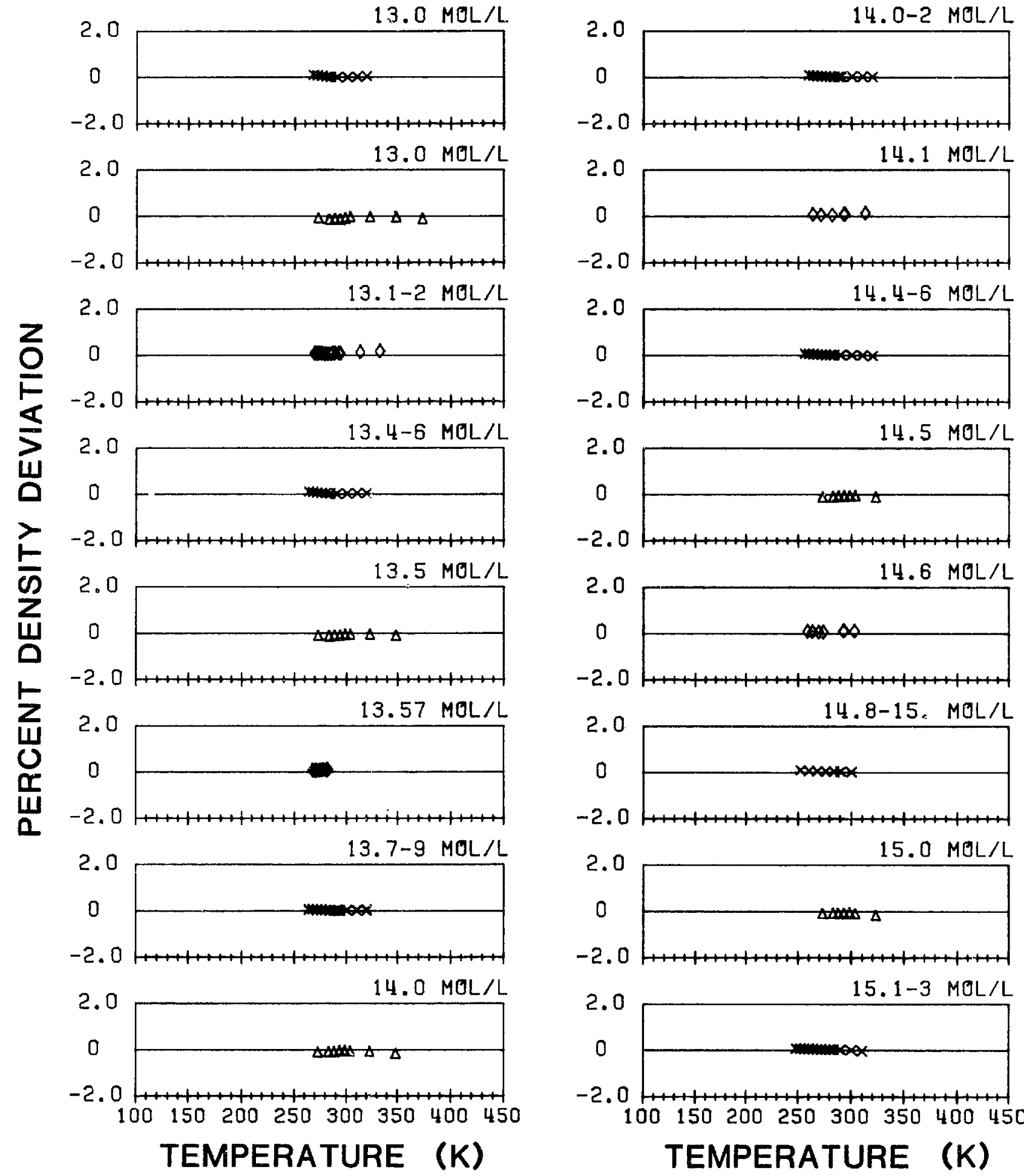
$\checkmark$ THOMAS [37]
$\triangle$ DOUSLIN [12]
$\times$ straty [6]

$\begin{array}{lll}0 & \text { THOMAS }[33] \\ \Delta & \text { DOUSLIN } & \text { [12] }\end{array} \quad \times$ STRATY [33]

$\begin{array}{lll}0 & \text { THOMAS }[33] \\ \Delta & \text { DOUSLIN } & \text { [12] }\end{array}$

15. 1-3 MOL/L

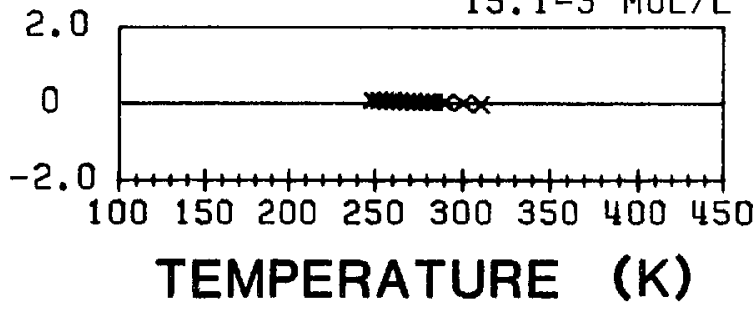

Figure A-1. Comparisons to PVT Data (Continued) 


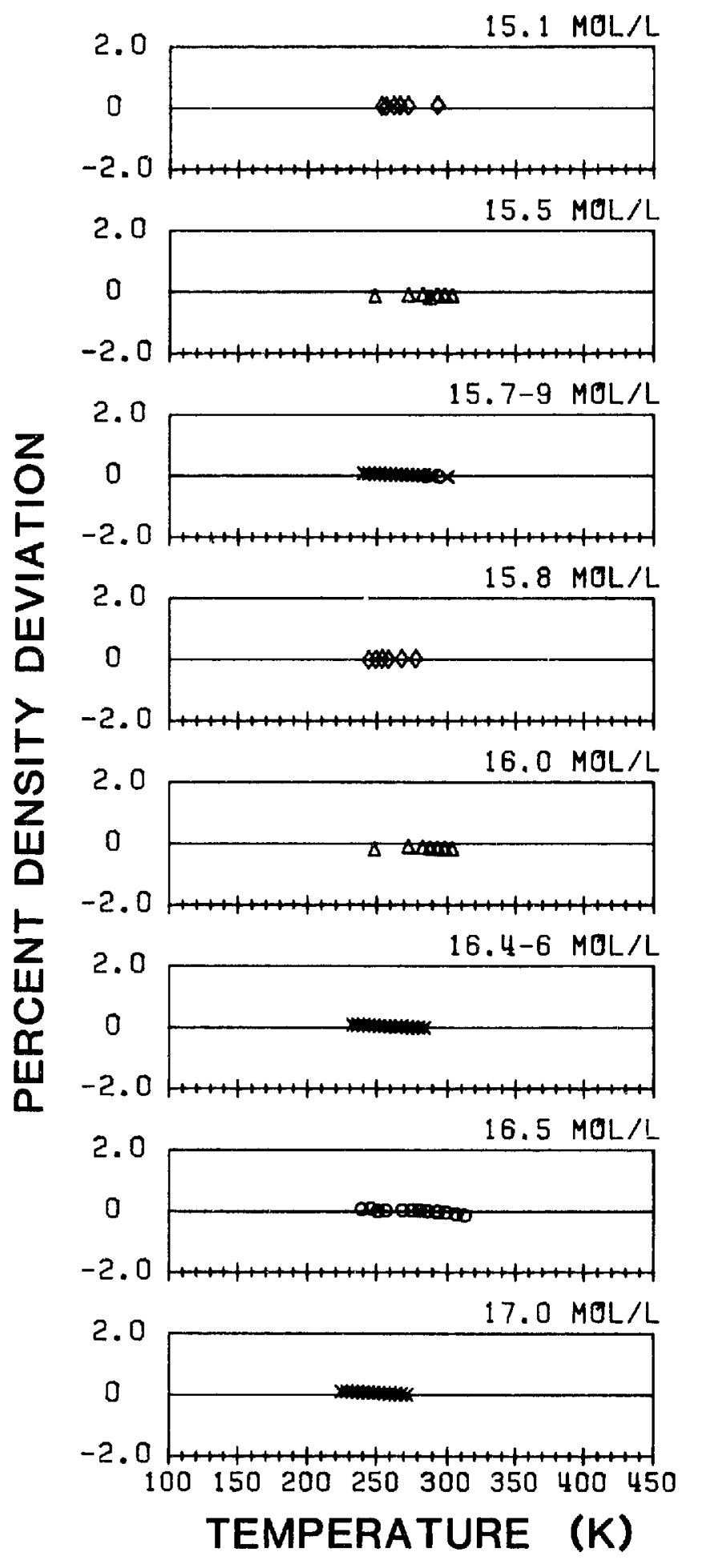

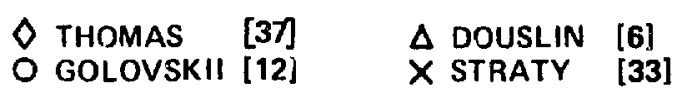
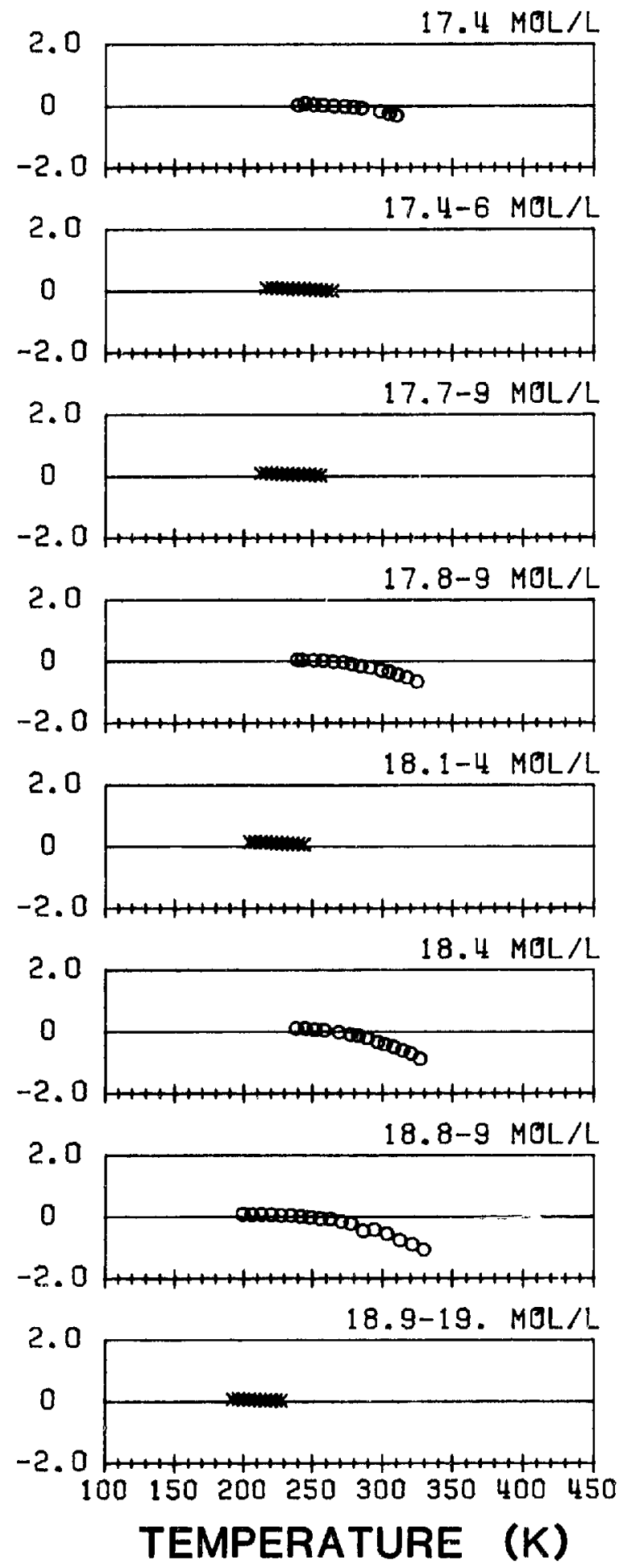

O GOLOVSKII [12] X STRATY [33]

Figure A-1. Comparisons to PVT Data (Continued) 


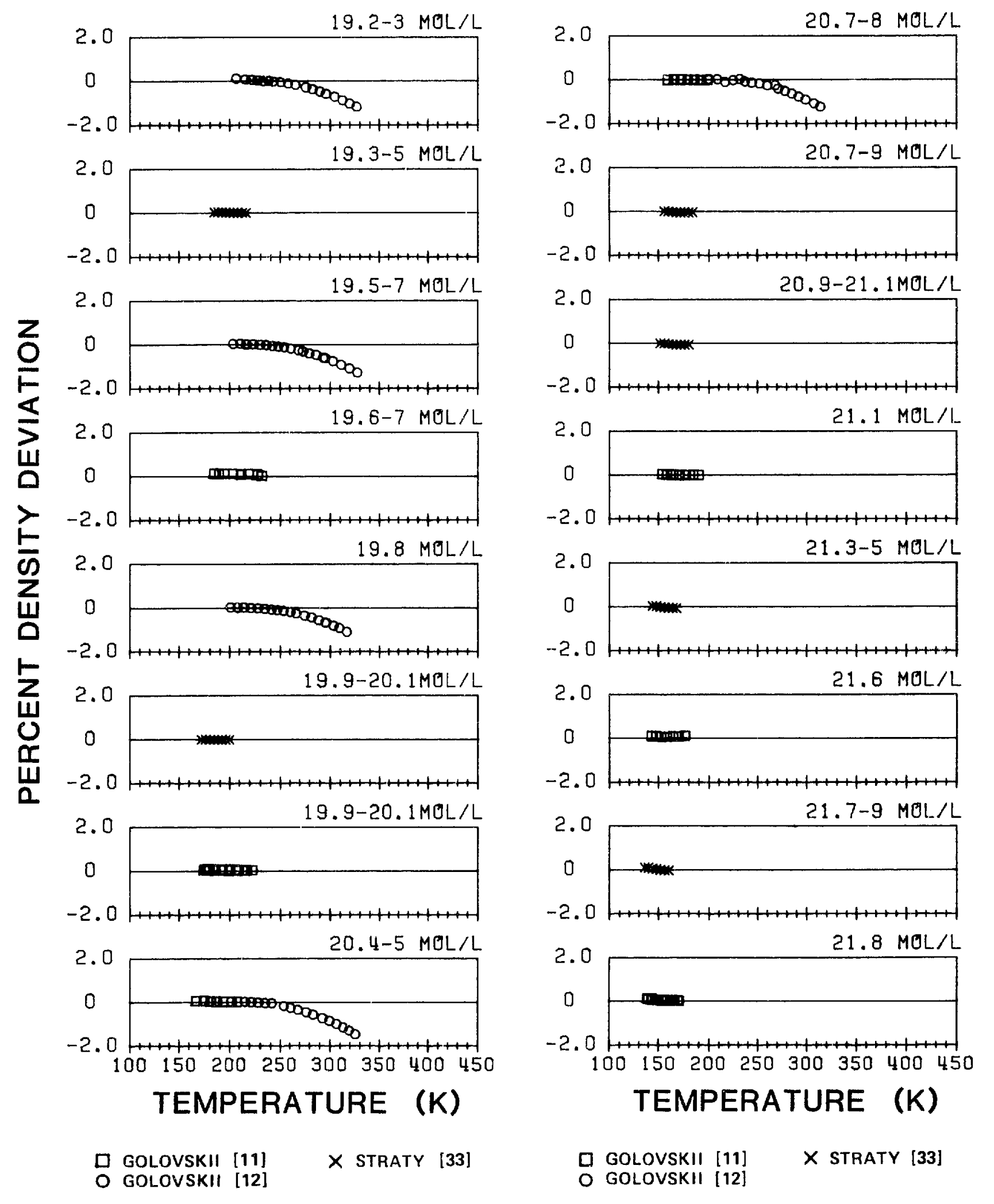

Figure A-1. Comparisons to PVT Data (Continued) 


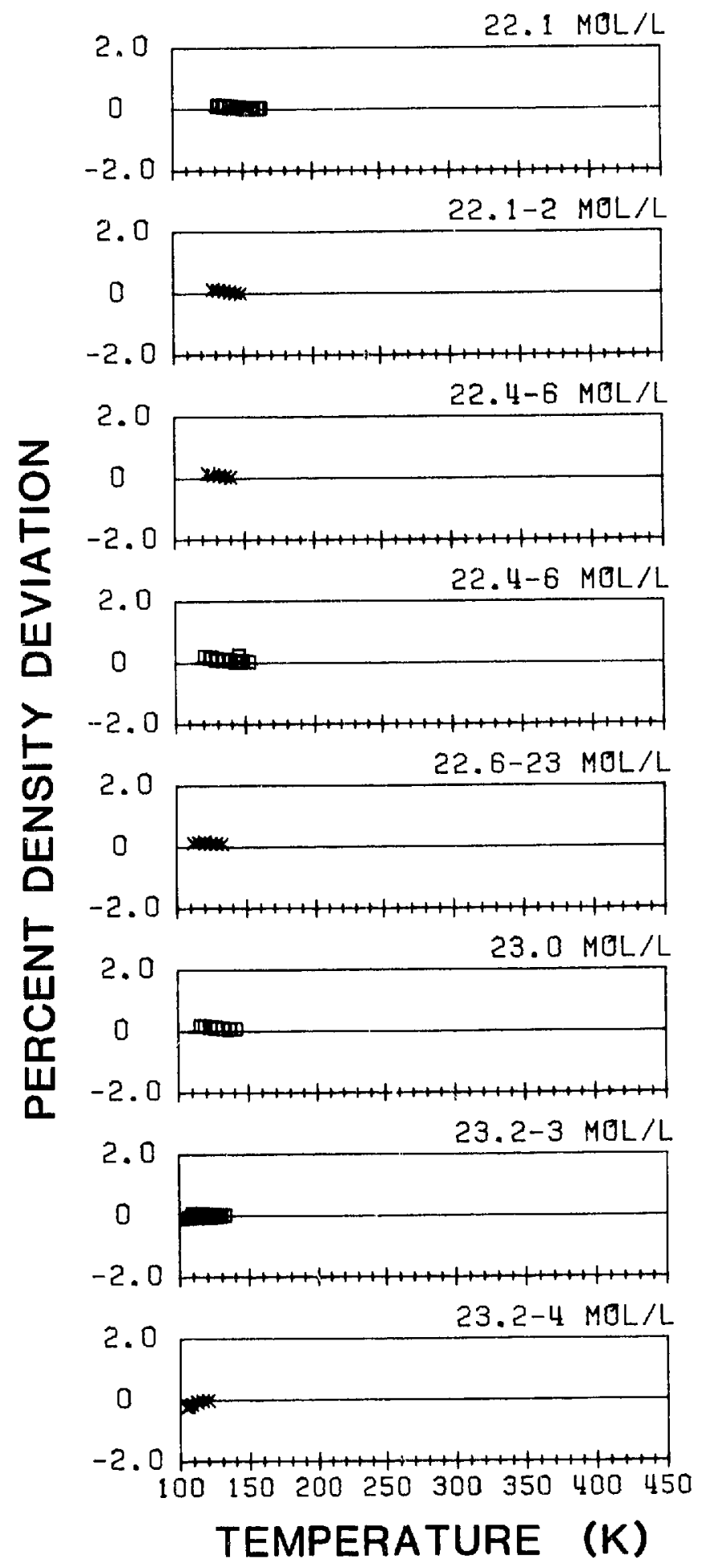

口 GOLOVSKII [11] X STRATY

Figure A-1. Comparisons to PVT Data (Continued) 
Table A-1. Data Points with Deviations Exceeding the Scale of Figure $A-1$.

(ISOTHERMAL DATA)

\begin{tabular}{|c|c|c|c|c|}
\hline $\begin{array}{c}\text { ielperature } \\
k\end{array}$ & $\begin{array}{c}\text { Pressure } \\
\mathrm{MPa}\end{array}$ & $\begin{array}{l}\text { Density } \\
\mathrm{mol} / \mathrm{dm}^{3}\end{array}$ & $\begin{array}{c}\text { Densi y Deviation } \\
\text { Percent }\end{array}$ & Author \\
\hline $\begin{array}{l}282.35 \\
282.35 \\
282.35 \\
282.35 \\
282.40 \\
282.40 \\
282.45 \\
282.45 \\
282.45 \\
282.45 \\
282.45 \\
282.55 \\
282.55 \\
282.65 \\
282.65 \\
282.65 \\
282.65 \\
282.65 \\
282.65 \\
282.65 \\
282.85 \\
282.85 \\
283.15 \\
283.35 \\
283.35 \\
283.35 \\
283.35 \\
283.65 \\
283.65 \\
284.15 \\
323.15 \\
323.15 \\
323.15 \\
323.15 \\
348.15\end{array}$ & $\begin{array}{l}5.04 \\
5.04 \\
5.04 \\
5.04 \\
5.05 \\
5.05 \\
5.05 \\
5.05 \\
5.05 \\
5.05 \\
5.05 \\
5.06 \\
5.06 \\
5.08 \\
5.08 \\
5.08 \\
5.08 \\
5.08 \\
5.07 \\
5.07 \\
5.10 \\
5.10 \\
5.12 \\
5.17 \\
5.16 \\
5.14 \\
5.14 \\
5.20 \\
5.21 \\
5.27 \\
61.52 \\
39.64 \\
19.79 \\
2.43 \\
5.64\end{array}$ & $\begin{array}{l}8.50 \\
7.75 \\
7.50 \\
7.25 \\
7.65 \\
7.60 \\
8.00 \\
7.75 \\
7.65 \\
7.60 \\
7.50 \\
7.65 \\
7.60 \\
8.50 \\
8.00 \\
7.75 \\
7.65 \\
7.60 \\
6.75 \\
6.50 \\
8.00 \\
7.75 \\
6.75 \\
8.50 \\
8.00 \\
6.75 \\
6.50 \\
8.10 \\
8.71 \\
8.50 \\
17.01 \\
15.55 \\
12.93 \\
1.0 \\
2.52\end{array}$ & $\begin{array}{r}2.32 \\
7.44 \\
4.94 \\
2.29 \\
5.72 \\
5.45 \\
6.61 \\
4.96 \\
4.57 \\
3.94 \\
2.39 \\
3.01 \\
2.51 \\
3.59 \\
3.87 \\
2.80 \\
2.30 \\
2.08 \\
-2.03 \\
-2.07 \\
3.37 \\
2.20 \\
-2.02 \\
2.99 \\
2.57 \\
-2.00 \\
-2.14 \\
2.26 \\
2.71 \\
2.46 \\
2.02 \\
2.20 \\
2.33 \\
4.50 \\
2.14\end{array}$ & 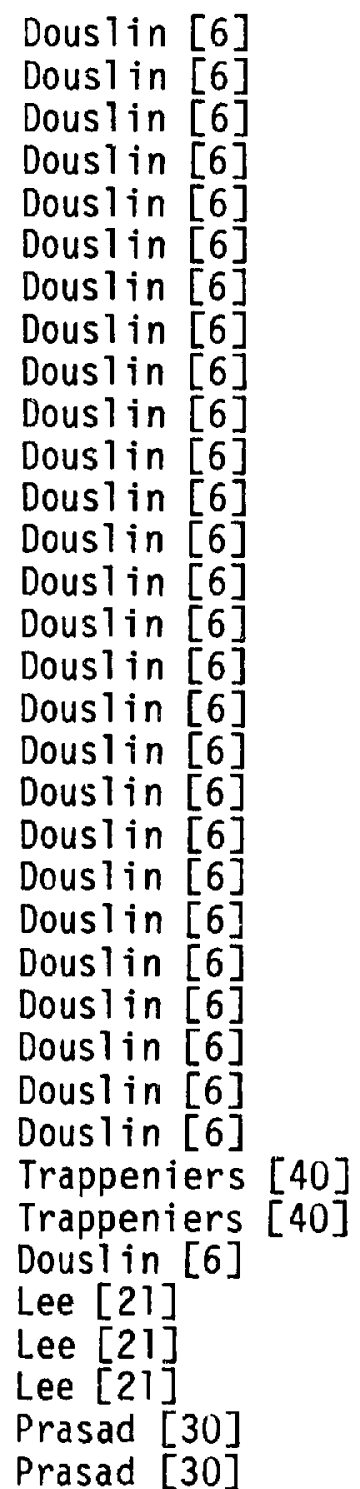 \\
\hline
\end{tabular}


Table A-1. (Continued)

(ISOCHURIC DATA)

\begin{tabular}{|c|c|c|c|c|}
\hline $\begin{array}{l}\text { Temperature } \\
\mathrm{K}\end{array}$ & $\begin{array}{c}\text { Pressure } \\
\mathrm{MPa}\end{array}$ & $\begin{array}{l}\text { Density } \\
\mathrm{mol} / \mathrm{dm}^{3}\end{array}$ & $\begin{array}{c}\text { Density Deviation } \\
\text { Percent }\end{array}$ & Author \\
\hline $\begin{array}{l}283.15 \\
282.65 \\
282.34 \\
283.15 \\
282.65 \\
282.34 \\
282.65 \\
282.55 \\
282.45 \\
282.34 \\
283.15 \\
282.65 \\
282.34 \\
282.36 \\
282.37 \\
282.38 \\
282.39 \\
282.40 \\
282.41 \\
282.42 \\
282.43 \\
282.45 \\
282.55 \\
282.65 \\
283.15 \\
282.65 \\
282.50 \\
282.34 \\
283.15 \\
283.15 \\
282.37 \\
282.34 \\
282.21 \\
282.19 \\
283.65 \\
282.34 \\
282.22 \\
282.19 \\
282.19 \\
282.19 \\
282.19 \\
282.17 \\
283.65 \\
282.34\end{array}$ & $\begin{array}{l}5.12 \\
5.07 \\
5.04 \\
5.13 \\
5.07 \\
5.04 \\
5.08 \\
5.06 \\
5.05 \\
5.04 \\
5.13 \\
5.07 \\
5.04 \\
5.04 \\
5.04 \\
5.05 \\
5.05 \\
5.05 \\
5.05 \\
5.05 \\
5.05 \\
5.05 \\
5.06 \\
5.08 \\
5.13 \\
5.08 \\
5.06 \\
5.04 \\
5.14 \\
5.14 \\
5.05 \\
5.04 \\
5.03 \\
5.02 \\
5.21 \\
5.04 \\
5.03 \\
5.02 \\
5.02 \\
5.02 \\
5.02 \\
5.02 \\
5.22 \\
5.04\end{array}$ & $\begin{array}{l}6.50 \\
7.51 \\
7.51 \\
7.59 \\
7.59 \\
7.59 \\
7.61 \\
7.61 \\
7.61 \\
7.61 \\
7.63 \\
7.63 \\
7.63 \\
7.64 \\
7.64 \\
7.64 \\
7.64 \\
7.64 \\
7.64 \\
7.64 \\
7.64 \\
7.64 \\
7.64 \\
7.64 \\
7.68 \\
7.68 \\
7.68 \\
7.68 \\
8.00 \\
8.50 \\
8.76 \\
8.76 \\
8.76 \\
8.76 \\
8.76 \\
8.76 \\
8.76 \\
8.76 \\
8.76 \\
8.76 \\
8.76 \\
8.76 \\
8.92 \\
8.92\end{array}$ & $\begin{array}{r}2.19 \\
3.98 \\
9.72 \\
2.25 \\
4.49 \\
10.48 \\
3.89 \\
4.96 \\
7.07 \\
9.90 \\
2.43 \\
4.79 \\
11.19 \\
7.58 \\
6.95 \\
6.40 \\
6.58 \\
5.68 \\
5.54 \\
4.58 \\
4.87 \\
3.69 \\
2.71 \\
2.22 \\
2.60 \\
5.11 \\
7.55 \\
11.52 \\
2.88 \\
3.24 \\
3.15 \\
3.08 \\
2.30 \\
2.08 \\
2.83 \\
3.64 \\
3.21 \\
2.93 \\
2.81 \\
2.98 \\
2.93 \\
2.29 \\
2.43 \\
2.44\end{array}$ & 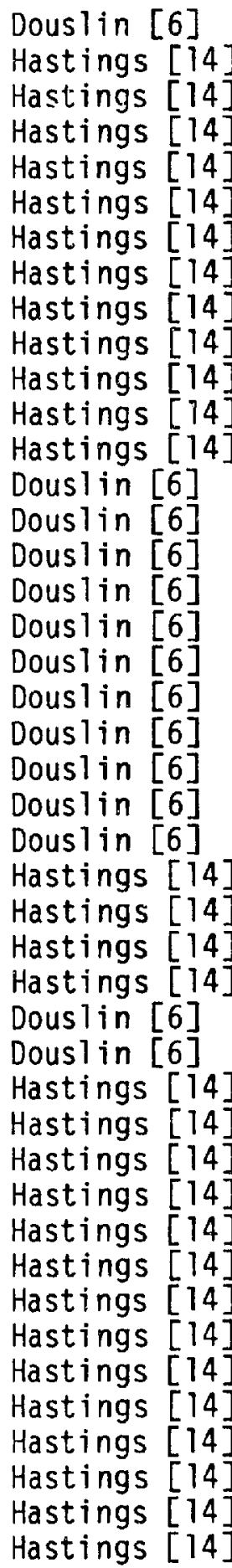 \\
\hline
\end{tabular}


Table A-2. Heat Capacity Data With Deviations Exceeding the Scales of Figures 9 and 12.

\begin{tabular}{cccc}
$\begin{array}{c}\text { Temperature } \\
K\end{array}$ & $\begin{array}{c}\text { Pressure } \\
\text { MPa }\end{array}$ & $\begin{array}{c}C_{v} \\
J /(\text { mol K })\end{array}$ & $\begin{array}{c}C_{v} \text { Deviations } \\
\text { Percent }\end{array}$ \\
\hline$C_{V}$ Data Points & of Weber [47] With Deviations Exceeding 5 percent \\
297.3 & 5.9 & 47.94 & 6.0 \\
291.3 & 5.5 & 51.23 & 10.0 \\
285.9 & 5.1 & 59.07 & 21.1 \\
289.8 & 5.8 & 54.88 & 10.5 \\
294.8 & 6.3 & 50.85 & 5.3 \\
\hline
\end{tabular}

$C_{v}$ Data Points of Gammon [9] With Deviations Exceeding 5 percent

$\begin{array}{rrrr}288.2 & 5.7 & 52.11 & 5.0 \\ 284.2 & 5.2 & 52.79 & 7.3 \\ 284.2 & 5.2 & 52.67 & 10.6 \\ 284.2 & 5.2 & 58.44 & 14.0 \\ 284.2 & 5.2 & 60.89 & 17.2 \\ 284.2 & 5.2 & 61.08 & 17.6 \\ 284.2 & 5.3 & 59.91 & 16.3 \\ 284.2 & 5.3 & 59.54 & 16.2 \\ 284.2 & 5.3 & 57.04 & 13.6 \\ 284.2 & 5.3 & 53.76 & 9.9\end{array}$


Table A-2. (Continued)

\begin{tabular}{cccc}
\hline $\begin{array}{c}\text { Temperature } \\
K\end{array}$ & Pressure & $C_{p}$ & $C_{p}$ Deviations \\
& $\mathrm{MPa}$ & $\mathrm{J} /(\mathrm{mol} \mathrm{K})$ & Percent \\
\hline
\end{tabular}

$C_{p}$ Data Points of Hejmadi and Powers [16] With Deviations Exceeding 6 percent

$\begin{array}{rlrr}292.0 & 6.2 & 479.7 & 8.3 \\ 292.1 & 6.21 & 479.9 & 8.4 \\ 299.0 & 6.21 & 180.7 & -7.3 \\ 300.4 & 6.21 & 153.1 & -12.0\end{array}$

$C_{p}$ Data Points of Vaschenko [42] With Deviations Exceeding 6 percent

168.9

249.6

262.7

262.7

270.3

273.8

273.8

273.6

273.6

273.7

277.7

277.4

277.6

280.4

280.3

281.6

281.4

281.3

282.1
0.5

3.1

3.4

3.9

5.7

4.1

4.2

4.5

4.7

5.2

5.0

5.0

5.1

5.9

5.9

5.2

5.2

5.2

5.2
62.28

110.1

106.7

101.2

117.0

147.3

143.1

137.5

131.9

157.0

148.8

142.6

141.7

184.2

174.7

302.5

233.0

249.1

358.2
$-8.9$

17.6

- 6.1

- 6.5

8.0

$-21.2$

$-19.8$

$-9.3$

$-6.8$

20.1

$-15.3$

$-14.5$

$-14.0$

21.1

17.0

10.6

- 7.4

6.2

12.3 

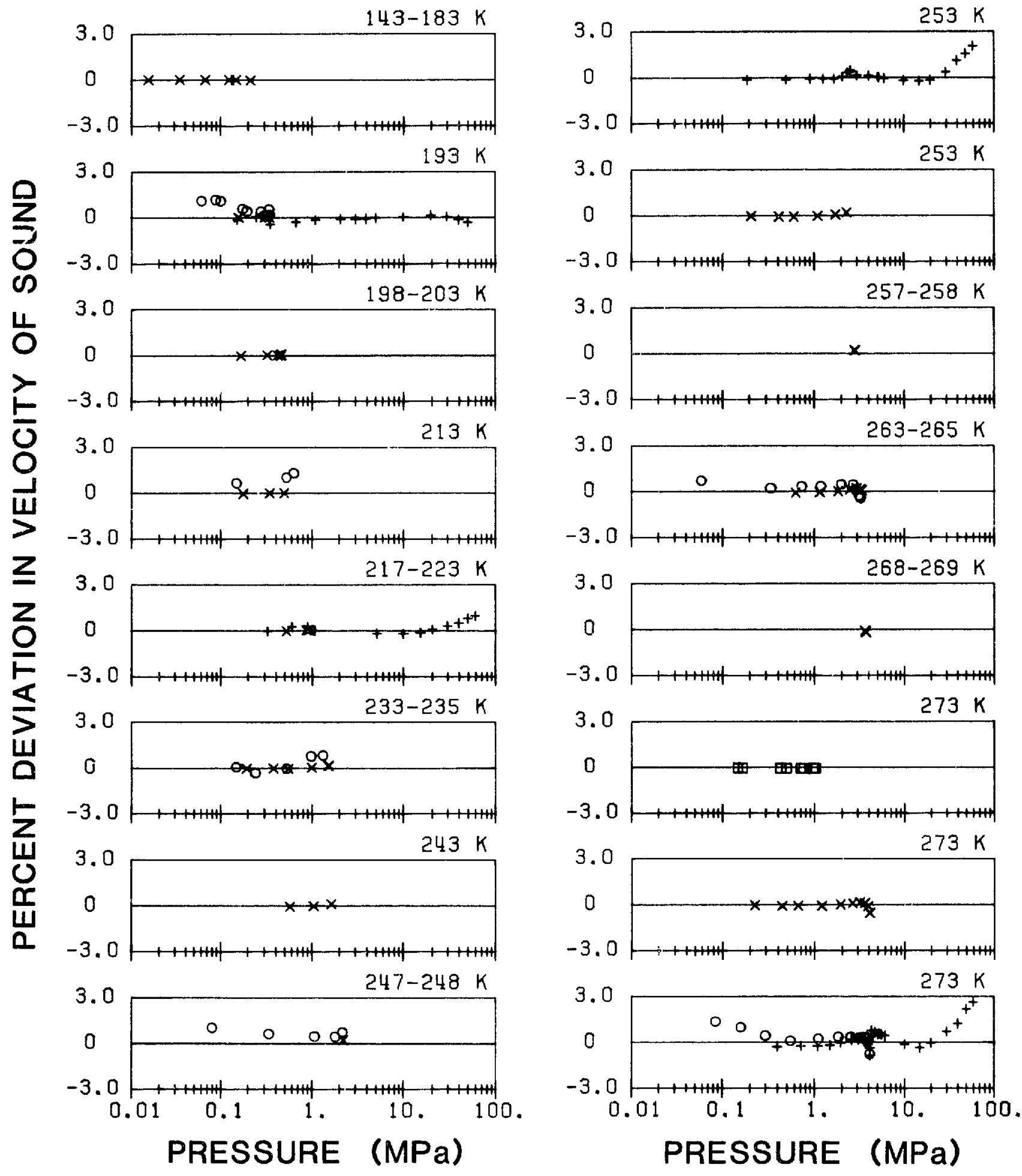

$\begin{array}{ll}+ \text { DREGULYAS } & {[7] \times \text { GAMMON }} \\ \text { O SOLDATENKO } & {[32]}\end{array}$

$\begin{array}{lll}+ \text { DREGULYAS } & {[7]} & \text { O SOLDATENKO } \\ \text { DMEHL } & {[23]} & \times \text { GAMMON }\end{array}$

[32] [9]

Figure A-2. Comparisons to Velocity of Sound Data 

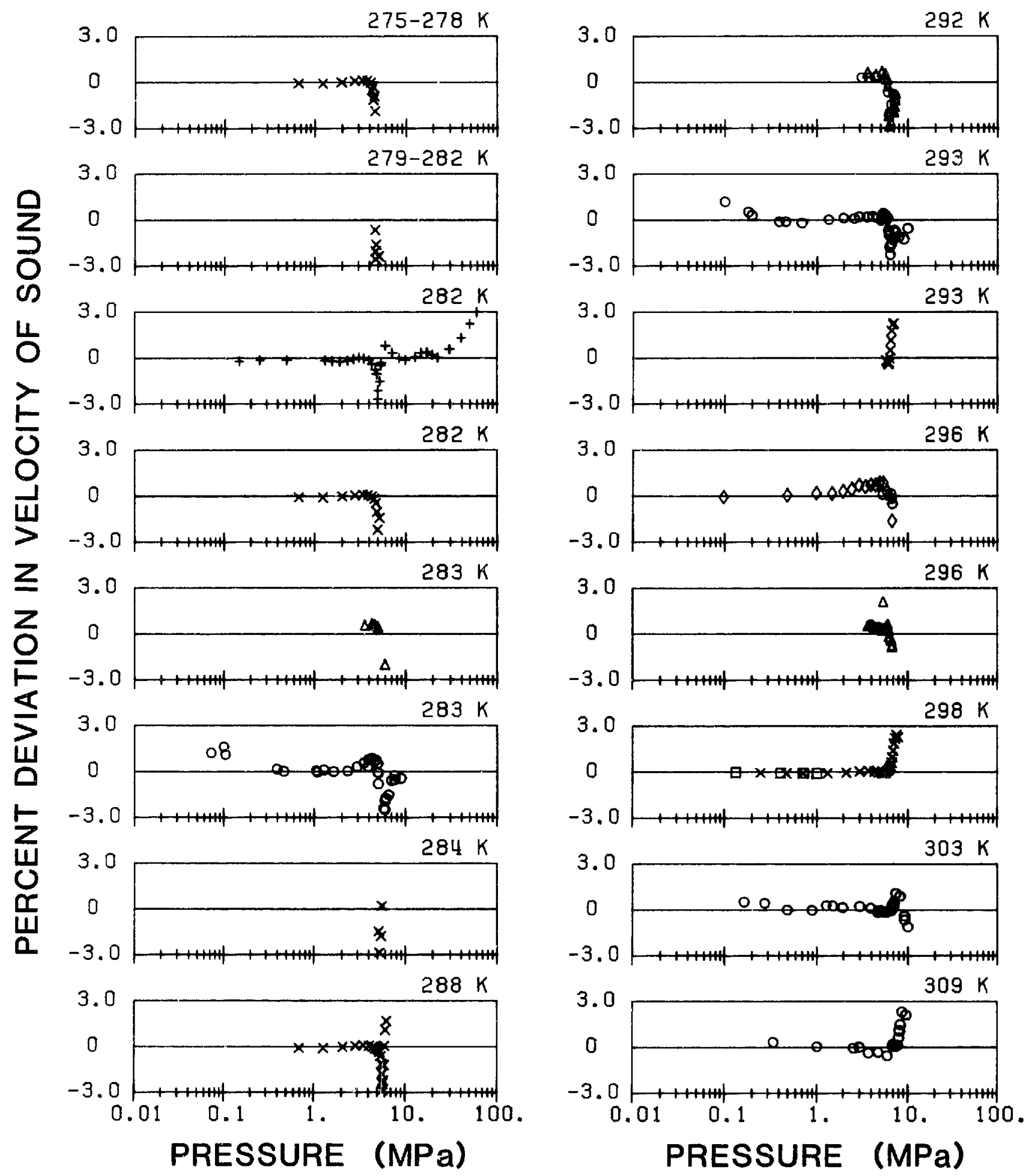

\section{PRESSURE (MPa)}
+ DREGULYAS
O SOLDATENKO

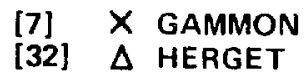
[9]
[17]
$X$ GAMMON [9]
D MEHL
O SOLDATENKO

Figure A-2. Comparisons to Velocity of Sound Data (Continued) 


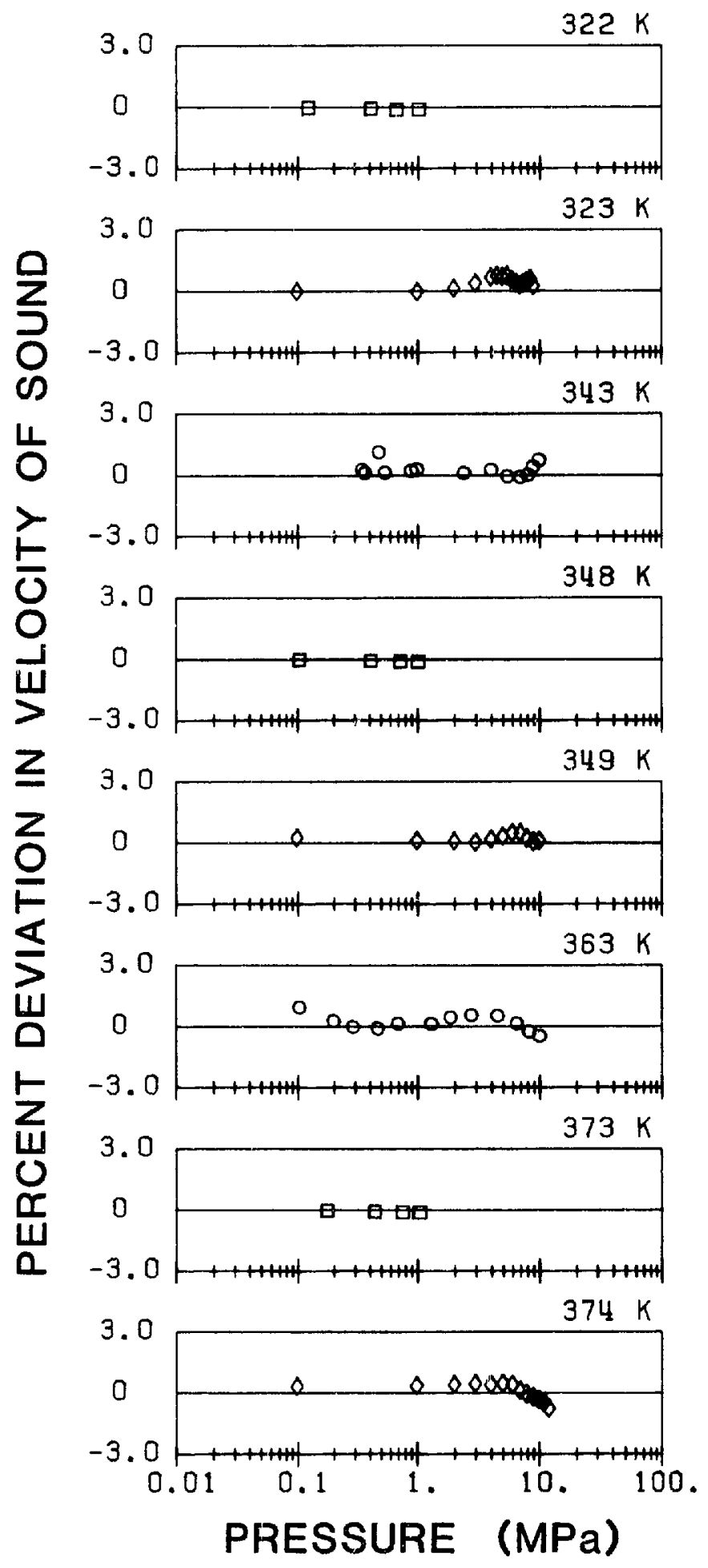

$\begin{array}{ll}\bigcirc \text { TERRES } & {[35]}\end{array} \quad$ O SOLDATENKO [32]
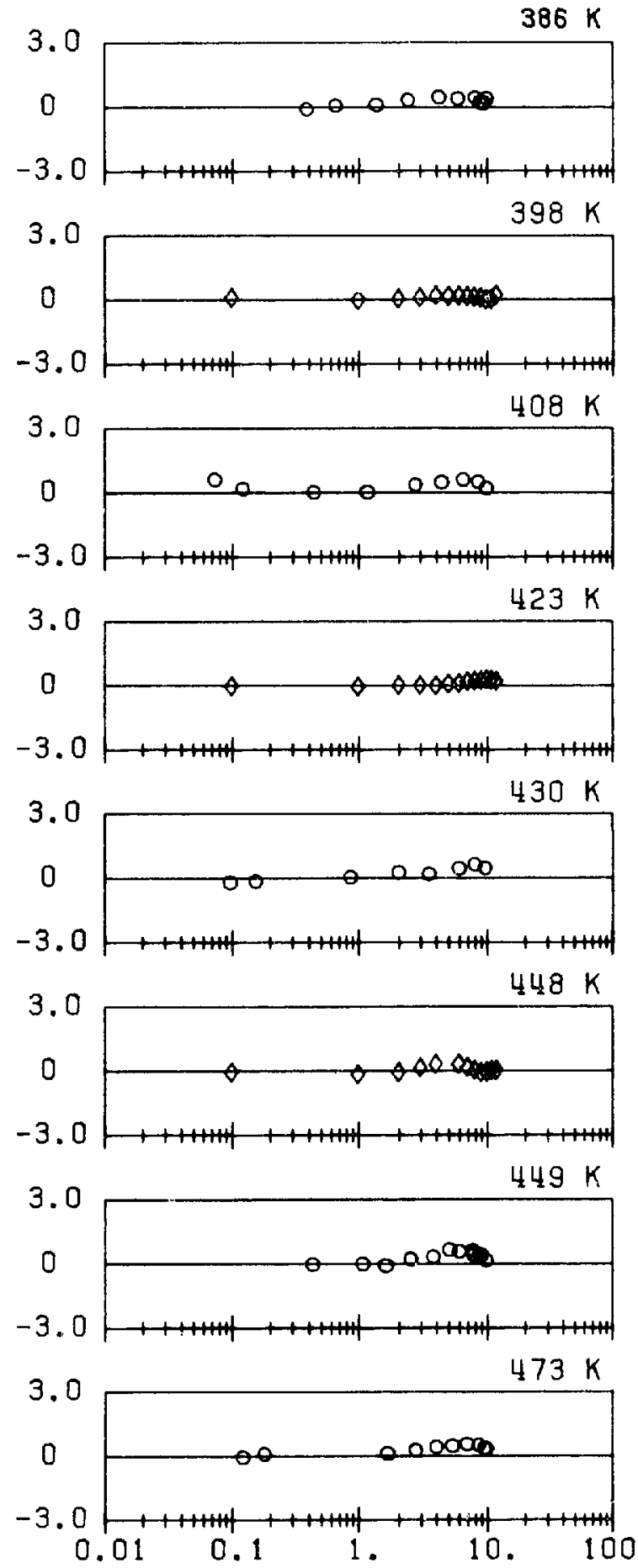
PRESSURE (MPa)

$\diamond$ TERRES [35] O SOLDATENKo

[32]

Figure A-2. Comparisons to Velocity of Sound Data (Continued) 
Table A-3. Velocity of Sound Data With Deviations Exceeding the scale of Figure A-2.

\begin{tabular}{|c|c|c|c|c|}
\hline $\begin{array}{c}\text { Temperature } \\
K\end{array}$ & $\begin{array}{l}\text { Pressure } \\
\mathrm{MPa}\end{array}$ & $\begin{array}{c}\text { Velocity of } \\
\text { Sound } \\
\mathrm{m} / \mathrm{s}\end{array}$ & $\begin{array}{c}\text { Velocity of Sourid } \\
\text { Deviation } \\
\text { Percent }\end{array}$ & Author \\
\hline $\begin{array}{l}280.15 \\
280.15 \\
281.15 \\
281.15 \\
281.15 \\
281.15 \\
281.65 \\
281.65 \\
281.65 \\
282.22 \\
282.22 \\
282.22 \\
282.22 \\
282.22 \\
282.22 \\
282.22 \\
282.35 \\
282.35 \\
282.35 \\
282.35 \\
282.35 \\
282.35 \\
282.35 \\
282.35 \\
282.35 \\
282.85 \\
282.85 \\
282.85 \\
282.85 \\
282.85 \\
282.85 \\
292.85 \\
282.85 \\
282.85 \\
282.35 \\
282.85 \\
282.85 \\
283.32 \\
283.32 \\
283.32 \\
283.32 \\
283.32 \\
283.32 \\
283.32 \\
283.32 \\
283.32 \\
283.32 \\
283.32 \\
283.32\end{array}$ & $\begin{array}{l}4.80 \\
4.82 \\
4.91 \\
4.99 \\
4.88 \\
4.91 \\
4.95 \\
4.96 \\
4.99 \\
5.02 \\
5.03 \\
5.03 \\
5.04 \\
5.06 \\
5.07 \\
5.14 \\
5.04 \\
5.04 \\
5.04 \\
5.01 \\
5.10 \\
5.04 \\
5.04 \\
5.06 \\
5.03 \\
5.13 \\
5.14 \\
5.17 \\
5.17 \\
5.17 \\
5.24 \\
5.37 \\
5.41 \\
5.47 \\
5.53 \\
5.60 \\
5.77 \\
5.16 \\
5.20 \\
5.21 \\
5.23 \\
5.26 \\
5.29 \\
5.29 \\
5.34 \\
5.45 \\
5.49 \\
5.50 \\
9.94\end{array}$ & $\begin{array}{l}208.1 \\
252.5 \\
224.9 \\
261.2 \\
210.4 \\
201.6 \\
201.9 \\
195.6 \\
231.0 \\
200.7 \\
185.1 \\
182.2 \\
196.5 \\
219.8 \\
226.1 \\
253.3 \\
163.5 \\
172.3 \\
175.0 \\
205.5 \\
238.2 \\
185.5 \\
170.0 \\
210.1 \\
194.1 \\
202.8 \\
193.0 \\
160.0 \\
162.0 \\
165.0 \\
225.0 \\
263.0 \\
280.8 \\
290.0 \\
298.6 \\
309.0 \\
318.0 \\
205.6 \\
189.4 \\
188.5 \\
203.3 \\
211.8 \\
223.1 \\
231.5 \\
241.1 \\
271.2 \\
283.7 \\
282.2 \\
517.5\end{array}$ & $\begin{array}{l}-3.60 \\
-5.38 \\
-9.40 \\
-3.13 \\
-3.01 \\
-6.06 \\
-5.92 \\
-8.71 \\
-7.12 \\
-5.81 \\
-13.96 \\
-15.75 \\
-16.94 \\
-10.28 \\
-9.23 \\
-4.67 \\
-29.12 \\
-22.48 \\
-20.77 \\
-4.63 \\
-4.95 \\
-19.85 \\
-24.24 \\
-10.98 \\
-9.53 \\
-16.35 \\
-24.45 \\
-54.64 \\
-54.18 \\
-51.38 \\
-17.85 \\
-10.11 \\
-5.71 \\
-5.22 \\
-5.00 \\
-4.33 \\
-7.18 \\
-7.09 \\
-25.44 \\
-28.14 \\
-21.85 \\
-20.16 \\
-14.53 \\
-12.94 \\
-12.62 \\
-7.45 \\
-4.86 \\
-5.94 \\
-6.00\end{array}$ & $\begin{array}{l}\text { Gammon [9] } \\
\text { Gammon [9] } \\
\text { Gammon [9] } \\
\text { Gammon [9] } \\
\text { Gammon [9] } \\
\text { Gammon [9] } \\
\text { Gammon [9] } \\
\text { Gammon [9] } \\
\text { Gammon [9] } \\
\text { Dregulyas [7] } \\
\text { Dregulyas [7] } \\
\text { Dregulyas [7] } \\
\text { Dregulyas [7] } \\
\text { Dregulyas [7] } \\
\text { Dregulyas [7] } \\
\text { Dregulyas [7] } \\
\text { Gammon [9] } \\
\text { Gammon [9] } \\
\text { Gammon [9] } \\
\text { Gammon [9] } \\
\text { Gammon [9] } \\
\text { Gammon [9] } \\
\text { Gammon [9] } \\
\text { Gammon [9] } \\
\text { Gammon [9] } \\
\text { Herget [17] } \\
\text { Herget [17] } \\
\text { Herget [17] } \\
\text { Herget [17] } \\
\text { Herget [17] } \\
\text { Herget [17] } \\
\text { Herget [17] } \\
\text { Herget [17] } \\
\text { Herget [17] } \\
\text { Herget [17] } \\
\text { Herget [17] } \\
\text { Herget [17] } \\
\text { Soldatenko [32] } \\
\text { Soldatenko [32] } \\
\text { Soldatenko [32] } \\
\text { Soldatenko [32] } \\
\text { Soldatenko [32] } \\
\text { Soldatenko [32] } \\
\text { Soldatenko [32] } \\
\text { Soldatenko [32] } \\
\text { Soldatenko [32] } \\
\text { Soldatenko [32] } \\
\text { Soldatenko [32] } \\
\text { Soldatenko [32] }\end{array}$ \\
\hline
\end{tabular}


Table A-3. (Continued)

\begin{tabular}{ccccc}
\hline $\begin{array}{c}\text { Temperature } \\
\mathrm{K}\end{array}$ & $\begin{array}{c}\text { Pressure } \\
\mathrm{MPa}\end{array}$ & $\begin{array}{c}\text { Velocity of } \\
\text { Sound } \\
\mathrm{m} / \mathrm{s}\end{array}$ & $\begin{array}{c}\text { Velocity of Sound } \\
\text { Deviation } \\
\text { Percent }\end{array}$ & Author \\
\hline 284.15 & 5.25 & 196.0 & -10.74 & Gammon [9] \\
284.15 & 5.32 & 228.8 & -4.59 & Gammon [9] \\
284.15 & 5.24 & 196.3 & -9.66 & Gammon [9] \\
284.15 & 5.28 & 211.7 & -7.73 & Gammon [9] \\
284.15 & 5.22 & 200.2 & -7.42 & Gammon [9] \\
284.15 & 5.26 & 200.9 & -10.04 & Gammon [9] \\
284.15 & 5.20 & 205.8 & -4.94 & Gammon [9] \\
291.85 & 6.23 & 234.1 & -3.13 & Herget [17] \\
291.85 & 6.30 & 240.4 & -3.28 & Herget [17] \\
291.85 & 6.37 & 246.5 & -3.01 & Herget [17] \\
291.85 & 6.87 & 300.3 & -5.49 & Herget [17] \\
308.67 & 9.05 & 326.0 & 4.10 & Soldatenko [32] \\
448.15 & 4.90 & 332.9 & -14.55 & Terres [35]
\end{tabular}




\section{APPENDIX B}

Thermodynamic Properties of Fluid Ethylene 


\begin{tabular}{|c|c|c|c|c|c|c|c|c|c|c|}
\hline Temp. & $\begin{array}{c}\text { Pressure } \\
\mathrm{MPa}\end{array}$ & $\begin{array}{l}\text { Density } \\
\text { mol/dm }\end{array}$ & $\begin{array}{l}\text { I sothern } \\
\text { DerIvatIve } \\
\text { dm 3-MPa/mol }\end{array}$ & $\begin{array}{c}\text { I sochore } \\
\text { Der I vat I ve } \\
\text { VPa/K }\end{array}$ & $\begin{array}{l}\text { Internal } \\
\text { Energy } \\
\mathrm{J} / \text { mol }\end{array}$ & $\begin{array}{c}\text { Enthal py } \\
\mathrm{J} / \mathrm{mol}\end{array}$ & $\begin{array}{c}\text { Entropy } \\
J /(m o \mid \cdot K)\end{array}$ & $\begin{array}{l}C_{V} \\
j / 6 \mathrm{~mol}\end{array}$ & $(\cdot)^{C_{p}}$ & $\begin{array}{c}\text { Velocity } \\
\text { of sound } \\
\mathrm{m} / \mathrm{s}\end{array}$ \\
\hline 103.985 & .00012 & $\begin{array}{r}23.389 \\
.000140\end{array}$ & $\begin{array}{r}46.008 \\
.864\end{array}$ & $\begin{array}{r}2.908 \\
.000\end{array}$ & $\begin{array}{r}6514.68 \\
21685.54\end{array}$ & $\begin{array}{r}6514.63 \\
22550.01\end{array}$ & $\begin{array}{r}81.4 \\
237.7\end{array}$ & $\begin{array}{l}39.48 \\
24.99\end{array}$ & $\begin{array}{l}74.41 \\
33.31\end{array}$ & $\begin{array}{c}1759 . \\
203 .\end{array}$ \\
\hline 104. & .00012 & $\begin{array}{r}23.389 \\
.000141\end{array}$ & $\begin{array}{r}46.027 \\
.864\end{array}$ & $\begin{array}{r}2.907 \\
.000\end{array}$ & $\begin{array}{r}6515.72 \\
21685.99\end{array}$ & $\begin{array}{r}6615.72 \\
22550.48\end{array}$ & $\begin{array}{r}84.4 \\
237.7\end{array}$ & $\begin{array}{l}39.49 \\
24.99\end{array}$ & $\begin{array}{l}74.39 \\
33.31\end{array}$ & $\begin{array}{l}1759 . \\
203 .\end{array}$ \\
\hline 105. & .00014 & $\begin{array}{r}23.327 \\
.000156\end{array}$ & $\begin{array}{r}47.235 \\
.873\end{array}$ & $\begin{array}{r}2.842 \\
.000\end{array}$ & $\begin{array}{r}6689.42 \\
21710.37\end{array}$ & $\begin{array}{r}6689.43 \\
22583.54\end{array}$ & $\begin{array}{r}85.1 \\
235.5\end{array}$ & $\begin{array}{l}40.07 \\
24.99\end{array}$ & $\begin{array}{l}73.08 \\
33.32\end{array}$ & $\begin{array}{l}1752 \\
204\end{array}$ \\
\hline 105. & .00017 & $\begin{array}{r}23.268 \\
.000195\end{array}$ & $\begin{array}{r}48.189 \\
.881\end{array}$ & $\begin{array}{r}2.783 \\
.000\end{array}$ & $\begin{array}{r}6751.97 \\
21735.74\end{array}$ & $\begin{array}{r}6761.98 \\
22616.78\end{array}$ & $\begin{array}{r}95.8 \\
235.4\end{array}$ & $\begin{array}{l}40.60 \\
25.00\end{array}$ & $\begin{array}{l}72.07 \\
33.33\end{array}$ & $\begin{array}{l}1745 \\
205\end{array}$ \\
\hline 107. & .00020 & $\begin{array}{r}23.211 \\
.000229\end{array}$ & $\begin{array}{r}48.934 \\
.889\end{array}$ & $\begin{array}{r}2.728 \\
.000\end{array}$ & $\begin{array}{r}6833.64 \\
21760.59\end{array}$ & $\begin{array}{r}6833.65 \\
22649.91\end{array}$ & $\begin{array}{r}86.5 \\
234.3\end{array}$ & $\begin{array}{l}41.08 \\
25.00\end{array}$ & $\begin{array}{l}71.29 \\
33.34\end{array}$ & $\begin{array}{c}1740 \\
206\end{array}$ \\
\hline 108. & .00024 & $\begin{array}{r}23.156 \\
.000267\end{array}$ & $\begin{array}{r}49.506 \\
.897\end{array}$ & $\begin{array}{r}2.678 \\
.000\end{array}$ & $\begin{array}{r}6904.61 \\
21785.44\end{array}$ & $\begin{array}{r}6904.62 \\
22683.03\end{array}$ & $\begin{array}{r}87.1 \\
233.2\end{array}$ & $\begin{array}{l}41.50 \\
25.01\end{array}$ & $\begin{array}{l}70.67 \\
33.34\end{array}$ & $\begin{array}{r}1734 . \\
206 .\end{array}$ \\
\hline 109. & .00028 & $\begin{array}{r}23.103 \\
.000311\end{array}$ & $\begin{array}{r}49.933 \\
.905\end{array}$ & $\begin{array}{r}2.631 \\
.000\end{array}$ & $\begin{array}{r}6975.02 \\
21810.27\end{array}$ & $\begin{array}{r}6975.03 \\
22716.12\end{array}$ & $\begin{array}{r}87.8 \\
232.2\end{array}$ & $\begin{array}{l}41.86 \\
25.02\end{array}$ & $\begin{array}{l}70.17 \\
33.35\end{array}$ & $\begin{array}{r}1727 \\
207\end{array}$ \\
\hline 110. & .00033 & $\begin{array}{r}23.051 \\
.000361\end{array}$ & $\begin{array}{r}50.237 \\
.914\end{array}$ & $\begin{array}{r}2.586 \\
.000\end{array}$ & $\begin{array}{r}7044.97 \\
21835.09\end{array}$ & $\begin{array}{r}7044.98 \\
22749.20\end{array}$ & $\begin{array}{r}83.4 \\
231.2\end{array}$ & $\begin{array}{l}42.18 \\
25.02\end{array}$ & $\begin{array}{l}69.75 \\
33.36\end{array}$ & $\begin{array}{l}1721 \\
208\end{array}$ \\
\hline 111. & .00039 & $\begin{array}{r}23.000 \\
.000418\end{array}$ & $\begin{array}{r}50.436 \\
.922\end{array}$ & $\begin{array}{r}2.545 \\
.000\end{array}$ & $\begin{array}{r}7114.54 \\
21859.90\end{array}$ & $\begin{array}{r}7114.55 \\
22782.25\end{array}$ & $\begin{array}{r}89.0 \\
230.2\end{array}$ & $\begin{array}{l}42.46 \\
25.03\end{array}$ & $\begin{array}{l}69.40 \\
33.37\end{array}$ & $\begin{array}{l}1714 . \\
209\end{array}$ \\
\hline 112. & .00045 & $\begin{array}{r}22.950 \\
.000482\end{array}$ & $\begin{array}{r}50.545 \\
.930\end{array}$ & $\begin{array}{r}2.506 \\
.000\end{array}$ & $\begin{array}{r}7183.79 \\
21884.69\end{array}$ & $\begin{array}{r}7183.81 \\
22815.29\end{array}$ & $\begin{array}{r}89.7 \\
229.2\end{array}$ & $\begin{array}{l}42.69 \\
25.04\end{array}$ & $\begin{array}{l}69.11 \\
33.38\end{array}$ & $\begin{array}{l}1709 \\
210\end{array}$ \\
\hline 113. & .00052 & $\begin{array}{r}22.901 \\
.000555\end{array}$ & $\begin{array}{r}50.576 \\
.938\end{array}$ & $\begin{array}{r}2.469 \\
.0011\end{array}$ & $\begin{array}{r}7252.77 \\
21909.46\end{array}$ & $\begin{array}{r}7252.79 \\
22848.29\end{array}$ & $\begin{array}{r}90.3 \\
228.3\end{array}$ & $\begin{array}{l}42.89 \\
25.04\end{array}$ & $\begin{array}{l}68.85 \\
33.39\end{array}$ & $\begin{array}{r}1701 . \\
211 .\end{array}$ \\
\hline 114. & .00060 & $\begin{array}{r}22.852 \\
.000636\end{array}$ & $\begin{array}{r}50.538 \\
.946\end{array}$ & $\begin{array}{r}2.434 \\
.000\end{array}$ & $\begin{array}{r}7321.51 \\
21934.21\end{array}$ & $\begin{array}{r}7321.53 \\
22881.27\end{array}$ & $\begin{array}{r}90.9 \\
227.4\end{array}$ & $\begin{array}{l}43.05 \\
25.05\end{array}$ & $\begin{array}{l}58.63 \\
33.41\end{array}$ & $\begin{array}{l}1695 \\
212\end{array}$ \\
\hline 115. & .00070 & $\begin{array}{r}22.805 \\
.000728\end{array}$ & $\begin{array}{r}50.442 \\
.954\end{array}$ & $\begin{array}{r}2.401 \\
.000\end{array}$ & $\begin{array}{r}7390.04 \\
21958.94\end{array}$ & $\begin{array}{r}7390.07 \\
22914.22\end{array}$ & $\begin{array}{r}91.5 \\
226.5\end{array}$ & $\begin{array}{l}43.17 \\
25.06\end{array}$ & $\begin{array}{l}68.44 \\
33.42\end{array}$ & $\begin{array}{l}1688 \\
213\end{array}$ \\
\hline 115. & .00080 & $\begin{array}{r}22.757 \\
.000830\end{array}$ & $\begin{array}{r}50.294 \\
.963\end{array}$ & $\begin{array}{r}2.369 \\
.000\end{array}$ & $\begin{array}{r}7458.39 \\
21983.65\end{array}$ & $\begin{array}{r}7458.42 \\
22947.13\end{array}$ & $\begin{array}{r}92.1 \\
225.6\end{array}$ & $\begin{array}{l}43.27 \\
25.07\end{array}$ & $\begin{array}{l}68.26 \\
33.43\end{array}$ & $\begin{array}{c}1682 \\
214\end{array}$ \\
\hline 117. & .00092 & $\begin{array}{r}22.710 \\
.000945\end{array}$ & $\begin{array}{r}50.100 \\
.971\end{array}$ & $\begin{array}{r}2.339 \\
.000\end{array}$ & $\begin{array}{r}7526.57 \\
22008.33\end{array}$ & $\begin{array}{r}7526.61 \\
22980.01\end{array}$ & $\begin{array}{r}92.7 \\
224.7\end{array}$ & $\begin{array}{l}43.34 \\
25.08\end{array}$ & $\begin{array}{l}68.11 \\
33.45\end{array}$ & $\begin{array}{c}1675 \\
215\end{array}$ \\
\hline 118. & .00105 & $\begin{array}{r}22.664 \\
.001072\end{array}$ & $\begin{array}{r}49.867 \\
.979\end{array}$ & $\begin{array}{r}2.310 \\
.000\end{array}$ & $\begin{array}{r}7594.60 \\
220.32 .99\end{array}$ & $\begin{array}{r}7594.65 \\
23012.86\end{array}$ & $\begin{array}{r}93.2 \\
223.9\end{array}$ & $\begin{array}{l}43.38 \\
25.09\end{array}$ & $\begin{array}{l}67.96 \\
33.47\end{array}$ & $\begin{array}{c}1669 . \\
216 .\end{array}$ \\
\hline 119. & .00120 & $\begin{array}{r}22.618 \\
.001213\end{array}$ & $\begin{array}{r}49.599 \\
.987\end{array}$ & $\begin{array}{r}2.282 \\
.000\end{array}$ & $\begin{array}{r}7662.50 \\
22057.62\end{array}$ & $\begin{array}{r}7662.55 \\
23045.67\end{array}$ & $\begin{array}{r}93.8 \\
223.1\end{array}$ & $\begin{array}{l}43.41 \\
25.10\end{array}$ & $\begin{array}{l}67.83 \\
33.48\end{array}$ & $\begin{array}{r}1662 . \\
217 .\end{array}$ \\
\hline 120 & .00136 & $\begin{array}{r}22.572 \\
.001370\end{array}$ & $\begin{array}{r}49.299 \\
.995\end{array}$ & $\begin{array}{r}2.256 \\
.000\end{array}$ & $\begin{array}{r}7730.27 \\
22082.23\end{array}$ & $\begin{array}{r}7730.33 \\
23078.44\end{array}$ & $\begin{array}{r}94.4 \\
222.3\end{array}$ & $\begin{array}{l}43.41 \\
25.11\end{array}$ & $\begin{array}{l}57.71 \\
33.50\end{array}$ & $\begin{array}{r}1656 \\
217\end{array}$ \\
\hline 121. & .00155 & $\begin{array}{r}22.526 \\
.001543\end{array}$ & $\begin{array}{r}48.973 \\
1.003\end{array}$ & $\begin{array}{r}2.230 \\
.000\end{array}$ & $\begin{array}{r}7797.93 \\
22106.80\end{array}$ & $\begin{array}{r}7797.99 \\
23111.16\end{array}$ & $\begin{array}{r}94.9 \\
221.5\end{array}$ & $\begin{array}{l}43.39 \\
25.13\end{array}$ & $\begin{array}{l}67.61 \\
33.52\end{array}$ & $\begin{array}{c}1649 . \\
218\end{array}$ \\
\hline 122. & .00176 & $\begin{array}{r}22.481 \\
.001735\end{array}$ & $\begin{array}{r}46.022 \\
1.011\end{array}$ & $\begin{array}{r}2.205 \\
.000\end{array}$ & $\begin{array}{r}7865.48 \\
22131.34\end{array}$ & $\begin{array}{r}7865.56 \\
23143.84\end{array}$ & $\begin{array}{r}95.5 \\
220.7\end{array}$ & $\begin{array}{l}43.36 \\
25.14\end{array}$ & $\begin{array}{l}67.50 \\
33.54\end{array}$ & $\begin{array}{r}1643 . \\
219 .\end{array}$ \\
\hline 123. & .00199 & $\begin{array}{r}22.435 \\
.001946\end{array}$ & $\begin{array}{r}48.250 \\
1.019\end{array}$ & $\begin{array}{r}2.181 \\
.000\end{array}$ & $\begin{array}{r}7932.93 \\
22155.85\end{array}$ & $\begin{array}{r}7933.02 \\
23176.47\end{array}$ & $\begin{array}{r}96.0 \\
220.0\end{array}$ & $\begin{array}{l}43.32 \\
25.16\end{array}$ & $\begin{array}{l}67.41 \\
33.57\end{array}$ & $\begin{array}{l}1636 \\
220\end{array}$ \\
\hline
\end{tabular}


Table B-1. (Continued)

\begin{tabular}{|c|c|c|c|c|c|c|c|c|c|c|}
\hline$\underset{K}{T}$ & $\begin{array}{l}\text { Pressure } \\
\text { MPa }\end{array}$ & $\begin{array}{l}\text { Density } \\
\text { mol/dm3 }\end{array}$ & $\begin{array}{l}\text { I sotherm } \\
\text { Der Ivat I ve } \\
\text { dn } 3 \text {-MPa/mol }\end{array}$ & $\begin{array}{c}\text { I sochore } \\
\text { Derlvative } \\
\mathrm{Ma} / \mathrm{K}\end{array}$ & $\begin{array}{l}\text { Internal } \\
\text { Energy } \\
\mathrm{J} / \mathrm{mol}\end{array}$ & $\begin{array}{c}\text { Enthalpy } \\
\mathrm{J} / \mathrm{mol}\end{array}$ & $\begin{array}{c}\text { Entropy } \\
\mathrm{J} /(\mathrm{mol} \cdot \mathrm{K})\end{array}$ & $\begin{array}{l}\mathrm{C}_{V} \\
\mathrm{~J} / \mathrm{lmo}\end{array}$ & $(\cdot k)^{C p}$ & $\begin{array}{c}\text { velocity } \\
\text { of sound } \\
\mathrm{m} / \mathrm{s}\end{array}$ \\
\hline 124. & .00224 & $\begin{array}{r}22.390 \\
.002177\end{array}$ & $\begin{array}{r}47.860 \\
1.026\end{array}$ & $\begin{array}{r}2.158 \\
.000\end{array}$ & $\begin{array}{r}8000.30 \\
22180.33\end{array}$ & $\begin{array}{r}8000.40 \\
23209.04\end{array}$ & $\begin{array}{r}95.6 \\
219.2\end{array}$ & $\begin{array}{l}43.25 \\
25.17\end{array}$ & $\begin{array}{l}67.32 \\
33.59\end{array}$ & $\begin{array}{r}1629 . \\
221 .\end{array}$ \\
\hline 125. & .00252 & $\begin{array}{r}22.345 \\
.002431\end{array}$ & $\begin{array}{r}47.453 \\
1.034\end{array}$ & $\begin{array}{r}2.136 \\
.000\end{array}$ & $\begin{array}{r}8067.58 \\
22204.76\end{array}$ & $\begin{array}{r}8067.69 \\
23241.57\end{array}$ & $\begin{array}{r}97.1 \\
218.5\end{array}$ & $\begin{array}{l}43.19 \\
25.19\end{array}$ & $\begin{array}{l}67.25 \\
33.61\end{array}$ & $\begin{array}{r}1623 . \\
222 .\end{array}$ \\
\hline 125. & .00283 & $\begin{array}{r}22.300 \\
.002710\end{array}$ & $\begin{array}{r}47.031 \\
1.042\end{array}$ & $\begin{array}{r}2.114 \\
.000\end{array}$ & $\begin{array}{r}3134.78 \\
22229.16\end{array}$ & $\begin{array}{r}8134.91 \\
23274.04\end{array}$ & $\begin{array}{r}97.7 \\
217.8\end{array}$ & $\begin{array}{l}43.10 \\
25.20\end{array}$ & $\begin{array}{l}67.17 \\
33.64\end{array}$ & $\begin{array}{c}1616 \\
223\end{array}$ \\
\hline 127. & .00317 & $\begin{array}{r}22.255 \\
.003014\end{array}$ & $\begin{array}{r}46.597 \\
1.050\end{array}$ & $\begin{array}{r}2.092 \\
.000\end{array}$ & $\begin{array}{r}8201.92 \\
22253.52\end{array}$ & $\begin{array}{r}8202.06 \\
23306.45\end{array}$ & $\begin{array}{r}98.2 \\
217.1\end{array}$ & $\begin{array}{l}43.01 \\
25.22\end{array}$ & $\begin{array}{l}67.11 \\
33.67\end{array}$ & $\begin{array}{l}1610 . \\
224 .\end{array}$ \\
\hline 128. & .00355 & $\begin{array}{r}22.210 \\
.003345\end{array}$ & $\begin{array}{r}46.152 \\
1.058\end{array}$ & $\begin{array}{r}2.072 \\
.000\end{array}$ & $\begin{array}{r}8268.99 \\
22277.84\end{array}$ & $\begin{array}{r}8269.15 \\
23338.80\end{array}$ & $\begin{array}{r}98.7 \\
216.5\end{array}$ & $\begin{array}{l}42.92 \\
25.24\end{array}$ & $\begin{array}{l}67.04 \\
33.70\end{array}$ & $\begin{array}{r}1603 . \\
224\end{array}$ \\
\hline 129. & .00396 & $\begin{array}{r}22.166 \\
.003706\end{array}$ & $\begin{array}{r}45.698 \\
1.065\end{array}$ & $\begin{array}{r}2.051 \\
.000\end{array}$ & $\begin{array}{r}8336.00 \\
22302.12\end{array}$ & $\begin{array}{r}0336.18 \\
23371.09\end{array}$ & $\begin{array}{r}99.2 \\
215.8\end{array}$ & $\begin{array}{l}42.81 \\
25.26\end{array}$ & $\begin{array}{l}65.99 \\
33.73\end{array}$ & $\begin{array}{r}1595 . \\
225 .\end{array}$ \\
\hline 130. & .00441 & $\begin{array}{r}22.121 \\
.004099\end{array}$ & $\begin{array}{r}45.235 \\
1.073\end{array}$ & $\begin{array}{r}2.031 \\
.000\end{array}$ & $\begin{array}{r}8402.95 \\
22326.35\end{array}$ & $\begin{array}{r}8403.15 \\
23403.30\end{array}$ & $\begin{array}{r}99.8 \\
215.1\end{array}$ & $\begin{array}{l}42.70 \\
25.28\end{array}$ & $\begin{array}{l}65.94 \\
33.77\end{array}$ & $\begin{array}{r}1590 . \\
226 .\end{array}$ \\
\hline 131. & .00491 & $\begin{array}{r}22.076 \\
.004525\end{array}$ & $\begin{array}{r}44.765 \\
1.081\end{array}$ & $\begin{array}{r}2.012 \\
.000\end{array}$ & $\begin{array}{r}3469.86 \\
22350.53\end{array}$ & $\begin{array}{r}8470.09 \\
23435.45\end{array}$ & $\begin{array}{l}100.3 \\
214.5\end{array}$ & $\begin{array}{l}42.59 \\
25.31\end{array}$ & $\begin{array}{l}65.89 \\
33.80\end{array}$ & $\begin{array}{r}1583 . \\
227\end{array}$ \\
\hline 132. & .00545 & $\begin{array}{r}22.031 \\
.004986\end{array}$ & $\begin{array}{r}44.289 \\
1.088\end{array}$ & $\begin{array}{r}1.993 \\
.000\end{array}$ & $\begin{array}{r}8536.73 \\
22374.67\end{array}$ & $\begin{array}{r}8536.98 \\
23467.53\end{array}$ & $\begin{array}{l}100.8 \\
213.9\end{array}$ & $\begin{array}{l}42.47 \\
25.33\end{array}$ & $\begin{array}{l}66.85 \\
33.34\end{array}$ & $\begin{array}{r}1576 . \\
228 .\end{array}$ \\
\hline 133. & .00604 & $\begin{array}{r}21.986 \\
.005485\end{array}$ & $\begin{array}{r}43.808 \\
1.096\end{array}$ & $\begin{array}{r}1.974 \\
.000\end{array}$ & $\begin{array}{r}8603.56 \\
22398.75\end{array}$ & $\begin{array}{r}8603.83 \\
23499.53\end{array}$ & $\begin{array}{l}101.3 \\
213.3\end{array}$ & $\begin{array}{l}42.34 \\
25.36\end{array}$ & $\begin{array}{l}66.82 \\
33.88\end{array}$ & $\begin{array}{r}1570 . \\
228 .\end{array}$ \\
\hline 134. & .00668 & $\begin{array}{r}21.941 \\
.006025\end{array}$ & $\begin{array}{r}43.324 \\
1.103\end{array}$ & $\begin{array}{r}1.956 \\
.000\end{array}$ & $\begin{array}{r}8670.35 \\
22422.78\end{array}$ & $\begin{array}{r}8670.66 \\
23531.45\end{array}$ & $\begin{array}{l}101.8 \\
212.7\end{array}$ & $\begin{array}{l}42.22 \\
25.38\end{array}$ & $\begin{array}{l}66.79 \\
33.92\end{array}$ & $\begin{array}{l}1563 . \\
229 .\end{array}$ \\
\hline 135. & .00738 & $\begin{array}{r}21.896 \\
.006606\end{array}$ & $\begin{array}{r}42.835 \\
1.111\end{array}$ & $\begin{array}{r}1.937 \\
.000\end{array}$ & $\begin{array}{r}8737.12 \\
22446.76\end{array}$ & $\begin{array}{r}8737.46 \\
23505.29\end{array}$ & $\begin{array}{l}102.3 \\
212.1\end{array}$ & $\begin{array}{l}42.09 \\
25.41\end{array}$ & $\begin{array}{l}66.76 \\
33.96\end{array}$ & $\begin{array}{l}1556 . \\
230 .\end{array}$ \\
\hline 136. & .00813 & $\begin{array}{r}21.850 \\
.007232\end{array}$ & $\begin{array}{r}42.345 \\
1.118\end{array}$ & $\begin{array}{r}1.920 \\
.000\end{array}$ & $\begin{array}{r}8803.86 \\
22470.68\end{array}$ & $\begin{array}{r}8804.24 \\
23595.05\end{array}$ & $\begin{array}{l}102.8 \\
211.5\end{array}$ & $\begin{array}{l}41.96 \\
25.44\end{array}$ & $\begin{array}{l}66.74 \\
34.01\end{array}$ & $\begin{array}{r}1550 . \\
231 .\end{array}$ \\
\hline 137. & .00895 & $\begin{array}{r}21.805 \\
.007905\end{array}$ & $\begin{array}{r}41.852 \\
1.125\end{array}$ & $\begin{array}{r}1.902 \\
.000\end{array}$ & $\begin{array}{r}8870.59 \\
22494.55\end{array}$ & $\begin{array}{r}8871.00 \\
23626.72\end{array}$ & $\begin{array}{l}103.3 \\
211.0\end{array}$ & $\begin{array}{l}41.83 \\
25.47\end{array}$ & $\begin{array}{l}66.73 \\
34.05\end{array}$ & $\begin{array}{r}1543 . \\
232\end{array}$ \\
\hline 138. & .00983 & $\begin{array}{r}21.759 \\
.008628\end{array}$ & $\begin{array}{r}41.359 \\
1.132\end{array}$ & $\begin{array}{r}1.884 \\
.000\end{array}$ & $\begin{array}{r}8937.30 \\
22518.36\end{array}$ & $\begin{array}{r}8937.75 \\
23658.30\end{array}$ & $\begin{array}{l}103.8 \\
210.4\end{array}$ & $\begin{array}{l}41.59 \\
25.50\end{array}$ & $\begin{array}{l}66.72 \\
34.10\end{array}$ & $\begin{array}{r}1536 . \\
232 .\end{array}$ \\
\hline 139. & .01079 & $\begin{array}{r}21.714 \\
.009403\end{array}$ & $\begin{array}{r}40.865 \\
1.140\end{array}$ & $\begin{array}{r}1.867 \\
.000\end{array}$ & $\begin{array}{r}9004.00 \\
22542.10\end{array}$ & $\begin{array}{r}9004.49 \\
23689.78\end{array}$ & $\begin{array}{l}104.2 \\
209.9\end{array}$ & $\begin{array}{l}41.56 \\
25.53\end{array}$ & $\begin{array}{l}66.71 \\
34.15\end{array}$ & $\begin{array}{r}1529 \\
233\end{array}$ \\
\hline 140 & .01182 & $\begin{array}{r}21.668 \\
.010233\end{array}$ & $\begin{array}{r}40.370 \\
1.147\end{array}$ & $\begin{array}{r}1.850 \\
.000\end{array}$ & $\begin{array}{r}9070.69 \\
22565.78\end{array}$ & $\begin{array}{r}9071.23 \\
23721.17\end{array}$ & $\begin{array}{l}104.7 \\
209.4\end{array}$ & $\begin{array}{l}41.43 \\
25.56\end{array}$ & $\begin{array}{l}66.71 \\
34.21\end{array}$ & $\begin{array}{r}1522 . \\
234 .\end{array}$ \\
\hline 141. & .01293 & $\begin{array}{r}21.622 \\
.011120\end{array}$ & $\begin{array}{r}39.877 \\
1.154\end{array}$ & $\begin{array}{r}1.833 \\
.000\end{array}$ & $\begin{array}{r}9137.38 \\
22589.40\end{array}$ & $\begin{array}{r}9137.98 \\
23752.47\end{array}$ & $\begin{array}{l}105.2 \\
208.8\end{array}$ & $\begin{array}{l}41.29 \\
25.60\end{array}$ & $\begin{array}{l}66.71 \\
34.26\end{array}$ & $\begin{array}{r}1515 . \\
235 .\end{array}$ \\
\hline 142 . & .01413 & $\begin{array}{r}21.576 \\
.012069\end{array}$ & $\begin{array}{r}39.383 \\
1.161\end{array}$ & $\begin{array}{r}1.816 \\
.000\end{array}$ & $\begin{array}{r}9204.07 \\
22612.95\end{array}$ & $\begin{array}{r}9204.73 \\
23783.66\end{array}$ & $\begin{array}{l}105.7 \\
208.3\end{array}$ & $\begin{array}{l}41.16 \\
25.63\end{array}$ & $\begin{array}{l}66.71 \\
34.32\end{array}$ & $\begin{array}{r}1508 \\
235 .\end{array}$ \\
\hline 143. & .01541 & $\begin{array}{r}21.530 \\
.013080\end{array}$ & $\begin{array}{r}38.892 \\
1.168\end{array}$ & $\begin{array}{r}1.800 \\
.000\end{array}$ & $\begin{array}{r}9270.77 \\
22636.44\end{array}$ & $\begin{array}{r}9271.48 \\
23814.74\end{array}$ & $\begin{array}{l}106.1 \\
207.8\end{array}$ & $\begin{array}{l}41.03 \\
25.67\end{array}$ & $\begin{array}{l}66.72 \\
34.38\end{array}$ & $\begin{array}{l}1501 . \\
236\end{array}$ \\
\hline 144. & .01679 & $\begin{array}{r}21.484 \\
.014159\end{array}$ & $\begin{array}{r}38.401 \\
1.174\end{array}$ & $\begin{array}{r}1.783 \\
.000\end{array}$ & $\begin{array}{r}9337.47 \\
22659.85\end{array}$ & $\begin{array}{r}9338.25 \\
23845.72\end{array}$ & $\begin{array}{l}106.6 \\
207.3\end{array}$ & $\begin{array}{l}40.90 \\
25.71\end{array}$ & $\begin{array}{l}66.73 \\
34.44\end{array}$ & $\begin{array}{r}1494 . \\
237 .\end{array}$ \\
\hline 145. & .01827 & $\begin{array}{r}21.437 \\
.015306\end{array}$ & $\begin{array}{r}37.913 \\
1.181\end{array}$ & $\begin{array}{r}1.767 \\
.000\end{array}$ & $\begin{array}{r}9404.19 \\
22683.19\end{array}$ & $\begin{array}{r}9405.04 \\
23876.58\end{array}$ & $\begin{array}{l}107.1 \\
206.9\end{array}$ & $\begin{array}{l}40.77 \\
25.75\end{array}$ & $\begin{array}{l}66.75 \\
34.51\end{array}$ & $\begin{array}{r}1487 . \\
238 .\end{array}$ \\
\hline
\end{tabular}


Table B-1. (Contlnued)

\begin{tabular}{|c|c|c|c|c|c|c|c|c|c|c|}
\hline$\underset{x}{T e m p .}$ & $\begin{array}{c}\text { Pressure } \\
\text { MPd }\end{array}$ & $\begin{array}{l}\text { Density } \\
\mathrm{mol}^{2} \mathrm{dm}^{3}\end{array}$ & $\begin{array}{l}\text { I sotherm } \\
\text { Der Ivative } \\
\text { dn } 3-\mathrm{MPa} / \mathrm{mol}\end{array}$ & $\begin{array}{c}\text { I sochore } \\
\text { Der I vative } \\
\text { vak }\end{array}$ & $\begin{array}{l}\text { Internal } \\
\text { Energy } \\
\text { J/mol }\end{array}$ & $\begin{array}{c}\text { Enthalpy } \\
\mathrm{J} / \mathrm{mol}\end{array}$ & $\begin{array}{l}\text { Entropy } \\
\mathrm{J} /(\mathrm{mol} \cdot \mathrm{K})\end{array}$ & $\begin{array}{l}\mathrm{C}_{V} \\
\mathrm{~J} / \mathrm{Cmo}\end{array}$ & $(\cdot k)^{C_{p}}$ & $\begin{array}{c}\text { velocity } \\
\text { of sound } \\
\mathrm{m} / \mathrm{s}\end{array}$ \\
\hline 146. & .01985 & $\begin{array}{r}21.391 \\
.016527\end{array}$ & $\begin{array}{r}37.427 \\
1.188\end{array}$ & $\begin{array}{r}1.751 \\
.000\end{array}$ & $\begin{array}{r}9470.92 \\
22706.46\end{array}$ & $\begin{array}{r}9471.85 \\
23907.33\end{array}$ & $\begin{array}{l}107.5 \\
206.4\end{array}$ & $\begin{array}{l}40.64 \\
25.79\end{array}$ & $\begin{array}{l}66.77 \\
34.58\end{array}$ & $\begin{array}{r}1480 \\
238\end{array}$ \\
\hline 147 & .02154 & $\begin{array}{r}21.344 \\
.017823\end{array}$ & $\begin{array}{r}36.944 \\
1.194\end{array}$ & $\begin{array}{r}1.734 \\
.000\end{array}$ & $\begin{array}{r}9537.67 \\
22729.65\end{array}$ & $\begin{array}{r}9538.68 \\
23937.96\end{array}$ & $\begin{array}{l}108.0 \\
205.9\end{array}$ & $\begin{array}{l}40.51 \\
25.83\end{array}$ & $\begin{array}{l}66.79 \\
34.64\end{array}$ & $\begin{array}{r}1473 . \\
239 .\end{array}$ \\
\hline 148. & .02334 & $\begin{array}{r}21.297 \\
.019198\end{array}$ & $\begin{array}{r}36.463 \\
1.201\end{array}$ & $\begin{array}{r}1.718 \\
.000\end{array}$ & $\begin{array}{r}9604.45 \\
22752.77\end{array}$ & $\begin{array}{r}9605.54 \\
23968.48\end{array}$ & $\begin{array}{l}108.4 \\
205.5\end{array}$ & $\begin{array}{l}40.39 \\
25.87\end{array}$ & $\begin{array}{l}66.82 \\
34.72\end{array}$ & $\begin{array}{r}1466 \\
240\end{array}$ \\
\hline 149. & .02526 & $\begin{array}{r}21.250 \\
.020656\end{array}$ & $\begin{array}{r}35.985 \\
1.207\end{array}$ & $\begin{array}{r}1.703 \\
.000\end{array}$ & $\begin{array}{r}9671.24 \\
22775.81\end{array}$ & $\begin{array}{r}9672.43 \\
23998.87\end{array}$ & $\begin{array}{l}108.9 \\
205.0\end{array}$ & $\begin{array}{l}40.26 \\
25.92\end{array}$ & $\begin{array}{l}66.84 \\
34.79\end{array}$ & $\begin{array}{r}1459 . \\
240 .\end{array}$ \\
\hline 150. & .02731 & $\begin{array}{r}21.202 \\
.022200\end{array}$ & $\begin{array}{r}35.511 \\
1.214\end{array}$ & $\begin{array}{r}1.687 \\
.000\end{array}$ & $\begin{array}{r}9738.07 \\
22798.77\end{array}$ & $\begin{array}{r}9739.36 \\
24029.13\end{array}$ & $\begin{array}{l}109.3 \\
204.6\end{array}$ & $\begin{array}{l}40.14 \\
25.97\end{array}$ & $\begin{array}{l}66.88 \\
34.87\end{array}$ & $\begin{array}{r}1452 \\
241\end{array}$ \\
\hline 151. & .02950 & $\begin{array}{r}21.155 \\
.023833\end{array}$ & $\begin{array}{r}35.040 \\
1.220\end{array}$ & $\begin{array}{r}1.671 \\
.000\end{array}$ & $\begin{array}{r}9804.92 \\
22821.64\end{array}$ & $\begin{array}{r}9806.32 \\
24059.26\end{array}$ & $\begin{array}{l}109.8 \\
204.2\end{array}$ & $\begin{array}{l}40.02 \\
26.01\end{array}$ & $\begin{array}{l}66.91 \\
34.95\end{array}$ & $\begin{array}{r}1445 \\
242\end{array}$ \\
\hline 152. & .03182 & $\begin{array}{r}21.107 \\
.025558\end{array}$ & $\begin{array}{r}34.572 \\
1.226\end{array}$ & $\begin{array}{r}1.655 \\
.000\end{array}$ & $\begin{array}{r}9871.81 \\
22844.44\end{array}$ & $\begin{array}{r}9873.32 \\
24089.26\end{array}$ & $\begin{array}{l}110.2 \\
203.7\end{array}$ & $\begin{array}{l}39.91 \\
26.06\end{array}$ & $\begin{array}{l}66.95 \\
35.03\end{array}$ & $\begin{array}{c}1438 \\
242\end{array}$ \\
\hline 153. & .03428 & $\begin{array}{r}21.059 \\
.027380\end{array}$ & $\begin{array}{r}34.108 \\
1.232\end{array}$ & $\begin{array}{r}1.640 \\
.000\end{array}$ & $\begin{array}{r}9938.73 \\
22867.14\end{array}$ & $\begin{array}{r}9940.36 \\
24119.13\end{array}$ & $\begin{array}{l}110.6 \\
203.3\end{array}$ & $\begin{array}{l}39.79 \\
26.11\end{array}$ & $\begin{array}{l}66.99 \\
35.11\end{array}$ & $\begin{array}{r}1431 . \\
243 .\end{array}$ \\
\hline 154. & .03689 & $\begin{array}{r}21.011 \\
.029302\end{array}$ & $\begin{array}{r}33.649 \\
1.238\end{array}$ & $\begin{array}{r}1.624 \\
.000\end{array}$ & $\begin{array}{l}10005.69 \\
22889.76\end{array}$ & $\begin{array}{l}10007.45 \\
24148.85\end{array}$ & $\begin{array}{l}111.1 \\
202.9\end{array}$ & $\begin{array}{l}39.68 \\
26.16\end{array}$ & $\begin{array}{l}67.03 \\
35.20\end{array}$ & $\begin{array}{l}1423 . \\
244\end{array}$ \\
\hline 155. & .03967 & $\begin{array}{r}20.963 \\
.031328\end{array}$ & $\begin{array}{r}33.193 \\
1.243\end{array}$ & $\begin{array}{r}1.609 \\
.000\end{array}$ & $\begin{array}{l}10072.69 \\
22912.29\end{array}$ & $\begin{array}{l}10074.58 \\
24178.44\end{array}$ & $\begin{array}{l}111.5 \\
202.5\end{array}$ & $\begin{array}{l}39.56 \\
26.22\end{array}$ & $\begin{array}{l}67.07 \\
35.29\end{array}$ & $\begin{array}{c}1416 \\
244 .\end{array}$ \\
\hline 156. & .04260 & $\begin{array}{r}20.914 \\
.033461\end{array}$ & $\begin{array}{r}32.741 \\
1.249\end{array}$ & $\begin{array}{r}1.594 \\
.000\end{array}$ & $\begin{array}{l}10139.73 \\
22934.73\end{array}$ & $\begin{array}{l}10141.77 \\
24207.87\end{array}$ & $\begin{array}{l}111.9 \\
202.1\end{array}$ & $\begin{array}{l}39.46 \\
26.27\end{array}$ & $\begin{array}{l}67.12 \\
35.38\end{array}$ & $\begin{array}{c}1409 \\
245\end{array}$ \\
\hline 157. & .04571 & $\begin{array}{r}20.866 \\
.035705\end{array}$ & $\begin{array}{r}32.293 \\
1.255\end{array}$ & $\begin{array}{r}1.578 \\
.000\end{array}$ & $\begin{array}{l}10206.81 \\
22957.08\end{array}$ & $\begin{array}{l}10209.00 \\
24237.16\end{array}$ & $\begin{array}{l}112.4 \\
201.7\end{array}$ & $\begin{array}{l}39.35 \\
26.33\end{array}$ & $\begin{array}{l}67.17 \\
35.48\end{array}$ & $\begin{array}{l}1402 \\
245\end{array}$ \\
\hline 158. & .04899 & $\begin{array}{r}20.817 \\
.038065\end{array}$ & $\begin{array}{r}31.849 \\
1.260\end{array}$ & $\begin{array}{r}1.563 \\
.000\end{array}$ & $\begin{array}{l}10273.94 \\
22979.34\end{array}$ & $\begin{array}{l}10276.30 \\
24266.30\end{array}$ & $\begin{array}{l}112.8 \\
201.4\end{array}$ & $\begin{array}{l}39.24 \\
26.38\end{array}$ & $\begin{array}{l}67.22 \\
35.57\end{array}$ & $\begin{array}{c}1394 \\
246\end{array}$ \\
\hline 159. & .05245 & $\begin{array}{r}20.768 \\
.040544\end{array}$ & $\begin{array}{r}31.410 \\
1.265\end{array}$ & $\begin{array}{r}1.548 \\
.000\end{array}$ & $\begin{array}{l}10341.12 \\
23001.49\end{array}$ & $\begin{array}{l}10343.64 \\
24295.28\end{array}$ & $\begin{array}{l}113.2 \\
201.0\end{array}$ & $\begin{array}{l}39.14 \\
26.44\end{array}$ & $\begin{array}{l}67.27 \\
35.67\end{array}$ & $\begin{array}{c}1387 \\
247\end{array}$ \\
\hline 160. & .05611 & $\begin{array}{r}20.718 \\
.043146\end{array}$ & $\begin{array}{r}30.975 \\
1.271\end{array}$ & $\begin{array}{r}1.533 \\
.000\end{array}$ & $\begin{array}{l}10408.34 \\
23023.55\end{array}$ & $\begin{array}{l}10411.05 \\
24324.11\end{array}$ & $\begin{array}{l}113.6 \\
200.6\end{array}$ & $\begin{array}{l}39.04 \\
26.50\end{array}$ & $\begin{array}{l}67.32 \\
35.78\end{array}$ & $\begin{array}{l}1380 \\
247\end{array}$ \\
\hline 161. & .05997 & $\begin{array}{r}20.669 \\
.045876\end{array}$ & $\begin{array}{r}30.545 \\
1.276\end{array}$ & $\begin{array}{r}1.518 \\
.000\end{array}$ & $\begin{array}{l}10475.61 \\
23045.51\end{array}$ & $\begin{array}{l}10478.52 \\
24352.77\end{array}$ & $\begin{array}{l}114.1 \\
200.3\end{array}$ & $\begin{array}{l}38.95 \\
26.56\end{array}$ & $\begin{array}{l}67.38 \\
35.88\end{array}$ & $\begin{array}{c}1372 . \\
248\end{array}$ \\
\hline 152. & .06404 & $\begin{array}{r}20.619 \\
.048737\end{array}$ & $\begin{array}{r}30.118 \\
1.281\end{array}$ & $\begin{array}{r}1.503 \\
.000\end{array}$ & $\begin{array}{l}10542.94 \\
23067.37\end{array}$ & $\begin{array}{l}10546.05 \\
24381.27\end{array}$ & $\begin{array}{l}114.5 \\
199.9\end{array}$ & $\begin{array}{l}38.85 \\
26.62\end{array}$ & $\begin{array}{l}67.44 \\
35.99\end{array}$ & $\begin{array}{r}1365 \\
248\end{array}$ \\
\hline 163. & .06831 & $\begin{array}{r}20.559 \\
.051733\end{array}$ & $\begin{array}{r}23.697 \\
1.285\end{array}$ & $\begin{array}{r}1.488 \\
.000\end{array}$ & $\begin{array}{l}10610.32 \\
23089.12\end{array}$ & $\begin{array}{l}10613.64 \\
24409.60\end{array}$ & $\begin{array}{l}114.9 \\
199.5\end{array}$ & $\begin{array}{l}38.76 \\
26.69\end{array}$ & $\begin{array}{l}67.50 \\
36.10\end{array}$ & $\begin{array}{c}1358 \\
249\end{array}$ \\
\hline 164. & .07281 & $\begin{array}{r}20.519 \\
.054870\end{array}$ & $\begin{array}{r}29.279 \\
1.290\end{array}$ & $\begin{array}{r}1.474 \\
.000\end{array}$ & $\begin{array}{l}10677.75 \\
23110.77\end{array}$ & $\begin{array}{r}10681.30 \\
24437.76\end{array}$ & $\begin{array}{l}115.3 \\
199.2\end{array}$ & $\begin{array}{l}38.67 \\
26.75\end{array}$ & $\begin{array}{l}67.56 \\
36.22\end{array}$ & $\begin{array}{r}1350 . \\
250 .\end{array}$ \\
\hline 165. & .07754 & $\begin{array}{r}20.469 \\
.058150\end{array}$ & $\begin{array}{r}28.866 \\
1.295\end{array}$ & $\begin{array}{r}1.459 \\
.001\end{array}$ & $\begin{array}{l}10745.24 \\
23132.32\end{array}$ & $\begin{array}{l}10749.03 \\
24465.75\end{array}$ & $\begin{array}{l}115.7 \\
198.9\end{array}$ & $\begin{array}{l}38.58 \\
26.82\end{array}$ & $\begin{array}{l}67.62 \\
36.33\end{array}$ & $\begin{array}{r}1343 . \\
250\end{array}$ \\
\hline 166. & .08250 & $\begin{array}{r}20.419 \\
.061579\end{array}$ & $\begin{array}{r}28.457 \\
1.299\end{array}$ & $\begin{array}{r}1.444 \\
.001\end{array}$ & $\begin{array}{l}10812.79 \\
23153.75\end{array}$ & $\begin{array}{l}10816.83 \\
24493.56\end{array}$ & $\begin{array}{l}116.1 \\
198.5\end{array}$ & $\begin{array}{l}38.49 \\
26.89\end{array}$ & $\begin{array}{l}67.69 \\
36.46\end{array}$ & $\begin{array}{c}1336 . \\
25 \%\end{array}$ \\
\hline 167. & .08772 & $\begin{array}{r}20.368 \\
.065162\end{array}$ & $\begin{array}{r}28.053 \\
1.303\end{array}$ & $\begin{array}{r}1.430 \\
.001\end{array}$ & $\begin{array}{l}10880.39 \\
23175.07\end{array}$ & $\begin{array}{l}10884.70 \\
24521.18\end{array}$ & $\begin{array}{l}115.5 \\
198.2\end{array}$ & $\begin{array}{l}38.41 \\
26.95\end{array}$ & $\begin{array}{l}67.75 \\
36.58\end{array}$ & $\begin{array}{l}1328 \\
251\end{array}$ \\
\hline
\end{tabular}


Table B-1. (Continued)

\begin{tabular}{|c|c|c|c|c|c|c|c|c|c|c|}
\hline$\underset{K}{\text { Temp. }}$ & $\begin{array}{c}\text { Pressure } \\
\mathrm{MPa}\end{array}$ & $\begin{array}{l}\text { Density } \\
\text { mol/dm3 }\end{array}$ & $\begin{array}{l}\text { I sotherm } \\
\text { Der I vatI ve } \\
\text { dn } 3 \mathrm{MPa} / \mathrm{mol}\end{array}$ & $\begin{array}{c}\text { I sochore } \\
\text { Der I vat I ve } \\
\mathrm{MPa} / \mathrm{K}\end{array}$ & $\begin{array}{l}\text { Internal } \\
\text { Energy } \\
\mathrm{J} / \mathrm{mol}\end{array}$ & $\begin{array}{c}\text { Enthalpy } \\
\mathrm{J} / \mathrm{mol}\end{array}$ & $\begin{array}{c}\text { Entropy } \\
\mathrm{J} /(\mathrm{mol} \cdot \mathrm{K})\end{array}$ & $\begin{array}{l}C_{v} \\
J / 1 m\end{array}$ & ${ }_{(\cdot k)}^{C_{p}}$ & $\begin{array}{c}\text { Velocity } \\
\text { of sound } \\
\mathrm{m} / \mathrm{s}\end{array}$ \\
\hline 168. & .09318 & $\begin{array}{r}20.317 \\
.068902\end{array}$ & $\begin{array}{r}27.653 \\
1.308\end{array}$ & $\begin{array}{r}1.416 \\
.001\end{array}$ & $\begin{array}{l}10948 . \mathrm{CS} \\
23196.28\end{array}$ & $\begin{array}{l}10952.64 \\
24548.63\end{array}$ & $\begin{array}{l}116.9 \\
197.9\end{array}$ & $\begin{array}{l}38.33 \\
27.02\end{array}$ & $\begin{array}{l}67.82 \\
36.70\end{array}$ & $\begin{array}{r}1321 . \\
252 .\end{array}$ \\
\hline 169. & .09890 & $\begin{array}{r}20.266 \\
.072804\end{array}$ & $\begin{array}{r}27.257 \\
1.312\end{array}$ & $\begin{array}{r}1.401 \\
.001\end{array}$ & $\begin{array}{l}11015.78 \\
23217.38\end{array}$ & $\begin{array}{l}11020.66 \\
24575.88\end{array}$ & $\begin{array}{l}117.3 \\
197.6\end{array}$ & $\begin{array}{l}38.25 \\
27.10\end{array}$ & $\begin{array}{l}67.89 \\
36.83\end{array}$ & $\begin{array}{l}1313 . \\
252 .\end{array}$ \\
\hline 170. & .10490 & $\begin{array}{r}20.215 \\
.076872\end{array}$ & $\begin{array}{r}26.865 \\
1.315\end{array}$ & $\begin{array}{r}1.387 \\
.001\end{array}$ & $\begin{array}{l}11083.56 \\
23238.35\end{array}$ & $\begin{array}{l}11088.75 \\
24602.95\end{array}$ & $\begin{array}{l}117.7 \\
197.2\end{array}$ & $\begin{array}{l}38.18 \\
27.17\end{array}$ & $\begin{array}{l}67.96 \\
36.97\end{array}$ & $\begin{array}{l}1306 . \\
253 .\end{array}$ \\
\hline 171. & .11117 & $\begin{array}{r}20.163 \\
.081112\end{array}$ & $\begin{array}{r}26.478 \\
1.319\end{array}$ & $\begin{array}{r}1.373 \\
.001\end{array}$ & $\begin{array}{l}11151.41 \\
23259.21\end{array}$ & $\begin{array}{l}11156.93 \\
24629.81\end{array}$ & $\begin{array}{l}118.1 \\
196.9\end{array}$ & $\begin{array}{l}38.10 \\
27.24\end{array}$ & $\begin{array}{l}68.03 \\
37.10\end{array}$ & $\begin{array}{l}1298 . \\
253 .\end{array}$ \\
\hline 172. & .11773 & $\begin{array}{r}20.1111 \\
.085529\end{array}$ & $\begin{array}{r}26.095 \\
1.323\end{array}$ & $\begin{array}{r}1.359 \\
.001\end{array}$ & $\begin{array}{l}11219.33 \\
23279.95\end{array}$ & $\begin{array}{l}11225.18 \\
24656.48\end{array}$ & $\begin{array}{l}118.5 \\
196.5\end{array}$ & $\begin{array}{l}38.03 \\
27.32\end{array}$ & $\begin{array}{l}68.11 \\
37.24\end{array}$ & $\begin{array}{r}1291 . \\
254 .\end{array}$ \\
\hline 173. & .12459 & $\begin{array}{r}20.059 \\
.090126\end{array}$ & $\begin{array}{r}25.716 \\
1.326\end{array}$ & $\begin{array}{r}1.344 \\
.001\end{array}$ & $\begin{array}{l}11287.30 \\
23300.57\end{array}$ & $\begin{array}{l}11293.51 \\
24682.95\end{array}$ & $\begin{array}{l}118.9 \\
196.3\end{array}$ & $\begin{array}{l}37.96 \\
27.39\end{array}$ & $\begin{array}{l}68.19 \\
37.39\end{array}$ & $\begin{array}{r}1283 . \\
254 .\end{array}$ \\
\hline 174. & .13175 & $\begin{array}{r}20.007 \\
.094910\end{array}$ & $\begin{array}{r}25.341 \\
1.329\end{array}$ & $\begin{array}{r}1.331 \\
.001\end{array}$ & $\begin{array}{l}11355.35 \\
23321.06\end{array}$ & $\begin{array}{l}11361.93 \\
24709.22\end{array}$ & $\begin{array}{l}119.3 \\
196.0\end{array}$ & $\begin{array}{l}37.90 \\
27.47\end{array}$ & $\begin{array}{l}68.26 \\
37.53\end{array}$ & $\begin{array}{r}1276 . \\
254 .\end{array}$ \\
\hline 175. & .13922 & $\begin{array}{r}19.955 \\
.099884\end{array}$ & $\begin{array}{r}24.969 \\
1.332\end{array}$ & $\begin{array}{r}1.317 \\
.001\end{array}$ & $\begin{array}{l}11423.46 \\
23341.42\end{array}$ & $\begin{array}{l}11430.44 \\
24735.27\end{array}$ & $\begin{array}{l}119.7 \\
195.8\end{array}$ & $\begin{array}{l}37.83 \\
27.55\end{array}$ & $\begin{array}{l}68.34 \\
37.68\end{array}$ & $\begin{array}{r}1268 . \\
255 \text {. }\end{array}$ \\
\hline 176. & .14702 & $\begin{array}{l}19.903 \\
.10505\end{array}$ & $\begin{array}{r}24.602 \\
1.335\end{array}$ & $\begin{array}{r}1.303 \\
.001\end{array}$ & $\begin{array}{l}11491.64 \\
23361.66\end{array}$ & $\begin{array}{l}11499.03 \\
24761.11\end{array}$ & $\begin{array}{l}120.1 \\
195.5\end{array}$ & $\begin{array}{l}37.77 \\
27.63\end{array}$ & $\begin{array}{l}68.42 \\
37.83\end{array}$ & $\begin{array}{r}1260 . \\
255 .\end{array}$ \\
\hline 177. & .15515 & $\begin{array}{l}19.850 \\
.11043\end{array}$ & $\begin{array}{r}24.239 \\
1.338\end{array}$ & $\begin{array}{r}1.289 \\
.001\end{array}$ & $\begin{array}{l}11559.90 \\
23381.76\end{array}$ & $\begin{array}{l}11567.71 \\
24786.74\end{array}$ & $\begin{array}{l}120.5 \\
195.2\end{array}$ & $\begin{array}{l}37.71 \\
27.71\end{array}$ & $\begin{array}{l}68.51 \\
37.99\end{array}$ & $\begin{array}{r}1253 . \\
256 .\end{array}$ \\
\hline 178. & .16361 & $\begin{array}{l}19.797 \\
.11600\end{array}$ & $\begin{array}{r}23.879 \\
1.340\end{array}$ & $\begin{array}{r}1.275 \\
.001\end{array}$ & $\begin{array}{l}11628.22 \\
23401.73\end{array}$ & $\begin{array}{l}11636.48 \\
24812.14\end{array}$ & $\begin{array}{l}120.9 \\
194.9\end{array}$ & $\begin{array}{l}37.65 \\
27.80\end{array}$ & $\begin{array}{l}68.59 \\
38.15\end{array}$ & $\begin{array}{r}1245 . \\
256 .\end{array}$ \\
\hline 179. & .1724 ) & $\begin{array}{r}19.744 \\
.12179\end{array}$ & $\begin{array}{r}23.523 \\
1.343\end{array}$ & $\begin{array}{r}1.262 \\
.001\end{array}$ & $\begin{array}{l}11696.62 \\
23421.56\end{array}$ & $\begin{array}{l}11705.35 \\
24837.32\end{array}$ & $\begin{array}{l}121.2 \\
194.6\end{array}$ & $\begin{array}{l}37.60 \\
27.88\end{array}$ & $\begin{array}{l}68.68 \\
38.31\end{array}$ & $\begin{array}{r}1238 . \\
256 .\end{array}$ \\
\hline 180. & .18160 & $\begin{array}{r}19.690 \\
.12780\end{array}$ & $\begin{array}{r}23.171 \\
1.345\end{array}$ & $\begin{array}{r}1.248 \\
.001\end{array}$ & $\begin{array}{l}11765.09 \\
23441.26\end{array}$ & $\begin{array}{l}11774.31 \\
24862.28\end{array}$ & $\begin{array}{l}121.6 \\
194.4\end{array}$ & $\begin{array}{l}37.54 \\
27.97\end{array}$ & $\begin{array}{l}68.77 \\
38.48\end{array}$ & $\begin{array}{r}1230 . \\
257\end{array}$ \\
\hline 181. & .19115 & $\begin{array}{l}19.637 \\
.13403\end{array}$ & $\begin{array}{r}22.822 \\
1.347\end{array}$ & $\begin{array}{r}1.235 \\
.001\end{array}$ & $\begin{array}{l}11833.64 \\
23460.81\end{array}$ & $\begin{array}{l}11843.37 \\
24887.00\end{array}$ & $\begin{array}{l}122.0 \\
194.1\end{array}$ & $\begin{array}{l}37.49 \\
28.05\end{array}$ & $\begin{array}{l}68.86 \\
38.65\end{array}$ & $\begin{array}{r}1222 . \\
257\end{array}$ \\
\hline 182 . & .20107 & $\begin{array}{r}19.583 \\
.14048\end{array}$ & $\begin{array}{r}22.476 \\
1.349\end{array}$ & $\begin{array}{r}1.22 \% \\
.001\end{array}$ & $\begin{array}{l}11902.26 \\
23480.22\end{array}$ & $\begin{array}{l}11912.53 \\
24911.48\end{array}$ & $\begin{array}{l}122.4 \\
193.8\end{array}$ & $\begin{array}{l}37.44 \\
28.14\end{array}$ & $\begin{array}{l}68.95 \\
38.83\end{array}$ & $\begin{array}{r}1215^{\circ} \\
258\end{array}$ \\
\hline 183. & .21137 & $\begin{array}{r}19.529 \\
.14717\end{array}$ & $\begin{array}{r}22.134 \\
1.350\end{array}$ & $\begin{array}{r}1.208 \\
.001\end{array}$ & $\begin{array}{l}11970.97 \\
23499.49\end{array}$ & $\begin{array}{l}11981.79 \\
24935.73\end{array}$ & $\begin{array}{l}122.8 \\
193.6\end{array}$ & $\begin{array}{l}37.40 \\
28.23\end{array}$ & $\begin{array}{l}69.05 \\
39.00\end{array}$ & $\begin{array}{r}1207 \\
258\end{array}$ \\
\hline 184. & .22208 & $\begin{array}{l}19.475 \\
.15410\end{array}$ & $\begin{array}{r}21.795 \\
1.352\end{array}$ & $\begin{array}{r}1.195 \\
.001\end{array}$ & $\begin{array}{l}12039.75 \\
23518.60\end{array}$ & $\begin{array}{l}12051.15 \\
24959.73\end{array}$ & $\begin{array}{l}123.1 \\
193.3\end{array}$ & $\begin{array}{l}37.35 \\
28.32\end{array}$ & $\begin{array}{l}69.15 \\
39.19\end{array}$ & $\begin{array}{l}1199 . \\
258 .\end{array}$ \\
\hline 185. & .23319 & $\begin{array}{l}19.420 \\
.16127\end{array}$ & $\begin{array}{r}21.460 \\
1.253\end{array}$ & $\begin{array}{r}1.182 \\
.001\end{array}$ & $\begin{array}{l}12108.62 \\
23537.57\end{array}$ & $\begin{array}{l}12120.63 \\
24983.49\end{array}$ & $\begin{array}{l}123.5 \\
193.1\end{array}$ & $\begin{array}{l}37.31 \\
28.41\end{array}$ & $\begin{array}{l}69.25 \\
39.37\end{array}$ & $\begin{array}{r}1192 . \\
259 .\end{array}$ \\
\hline 186. & .24471 & $\begin{array}{l}19.366 \\
.16870\end{array}$ & $\begin{array}{r}21.127 \\
1.354\end{array}$ & $\begin{array}{r}1.169 \\
.002\end{array}$ & $\begin{array}{l}12177.57 \\
23555.38\end{array}$ & $\begin{array}{l}12190.21 \\
25006.99\end{array}$ & $\begin{array}{l}123.9 \\
192.8\end{array}$ & $\begin{array}{l}37.27 \\
28.51\end{array}$ & $\begin{array}{l}69.35 \\
39.57\end{array}$ & $\begin{array}{r}1184 . \\
259 .\end{array}$ \\
\hline 187. & .25667 & $\begin{array}{l}19.311 \\
.17638\end{array}$ & $\begin{array}{r}20.798 \\
1.355\end{array}$ & $\begin{array}{r}1.156 \\
.002\end{array}$ & $\begin{array}{l}12246.51 \\
23575.03\end{array}$ & $\begin{array}{l}12259.90 \\
25030.23\end{array}$ & $\begin{array}{l}124.3 \\
192.6\end{array}$ & $\begin{array}{l}37.23 \\
28.60\end{array}$ & $\begin{array}{l}69.46 \\
39.76\end{array}$ & $\begin{array}{r}1176 . \\
259 .\end{array}$ \\
\hline 188. & .26905 & $\begin{array}{l}19.256 \\
.18432\end{array}$ & $\begin{array}{r}20.472 \\
1.355\end{array}$ & $\begin{array}{r}1.143 \\
.002\end{array}$ & $\begin{array}{l}12315.74 \\
23593.53\end{array}$ & $\begin{array}{l}12329.71 \\
25053.22\end{array}$ & $\begin{array}{l}124.6 \\
192.3\end{array}$ & $\begin{array}{l}37.19 \\
28.70\end{array}$ & $\begin{array}{l}69.57 \\
39.96\end{array}$ & $\begin{array}{r}1168 . \\
259 .\end{array}$ \\
\hline 189. & .28189 & $\begin{array}{l}19.200 \\
.19253\end{array}$ & $\begin{array}{r}20.148 \\
1.356\end{array}$ & $\begin{array}{r}1.131 \\
.002\end{array}$ & $\begin{array}{l}12384.95 \\
23611.86\end{array}$ & $\begin{array}{l}12399.64 \\
25075.93\end{array}$ & $\begin{array}{l}125.0 \\
192.1\end{array}$ & $\begin{array}{l}37.16 \\
28.79\end{array}$ & $\begin{array}{l}69.68 \\
40.17\end{array}$ & $\begin{array}{l}1161 . \\
260 .\end{array}$ \\
\hline
\end{tabular}


Table B-1. (Continued)

\begin{tabular}{|c|c|c|c|c|c|c|c|c|c|c|}
\hline$\underset{K}{\operatorname{Temp}}$ & $\begin{array}{c}\text { Pressure } \\
\text { MPa }\end{array}$ & $\begin{array}{l}\text { Density } \\
\text { mol/dm }\end{array}$ & $\begin{array}{l}\text { Isistherm } \\
\text { Der I vative } \\
\text { dm } 3 \text {-ifla/mol }\end{array}$ & $\begin{array}{c}\text { I sorhore } \\
\text { Derivative } \\
\text { MPak }\end{array}$ & $\begin{array}{c}\text { Internal } \\
\text { Energy } \\
\mathrm{J} / \mathrm{mol}\end{array}$ & $\begin{array}{c}\text { Enthalpy } \\
\mathrm{J} / \mathrm{mol}\end{array}$ & $\begin{array}{l}\text { Entropy } \\
\mathrm{J} /(\mathrm{mol} \cdot \mathrm{K})\end{array}$ & $\begin{array}{l}C_{V} \\
J / C m\end{array}$ & $\underset{(\cdot k)^{C_{p}}}{C_{p}}$ & $\begin{array}{c}\text { velocity } \\
\text { of sound } \\
\mathrm{m} / \mathrm{s}\end{array}$ \\
\hline :90. & .29517 & $\begin{array}{l}19.145 \\
.20102\end{array}$ & $\begin{array}{r}19.828 \\
1.356\end{array}$ & $\begin{array}{r}1.118 \\
.002\end{array}$ & $\begin{array}{l}12454.27 \\
23630.02\end{array}$ & $\begin{array}{l}12469.68 \\
25099.38\end{array}$ & $\begin{array}{l}125.4 \\
191.8\end{array}$ & $\begin{array}{l}37.13 \\
28.89\end{array}$ & $\begin{array}{l}69.80 \\
40.38\end{array}$ & $\begin{array}{r}1153 . \\
260\end{array}$ \\
\hline 191. & .30893 & $\begin{array}{r}19.089 \\
.20979\end{array}$ & $\begin{array}{r}19.510 \\
1.356\end{array}$ & $\begin{array}{r}1.105 \\
.002\end{array}$ & $\begin{array}{l}12523.67 \\
23648.02\end{array}$ & $\begin{array}{l}12539.86 \\
25120.56\end{array}$ & $\begin{array}{l}125.7 \\
191.6\end{array}$ & $\begin{array}{l}37.09 \\
28.99\end{array}$ & $\begin{array}{l}69.92 \\
40.59\end{array}$ & $\begin{array}{r}1145 \\
260\end{array}$ \\
\hline 192. & .32315 & $\begin{array}{l}19.033 \\
.21885\end{array}$ & $\begin{array}{r}19.195 \\
1.356\end{array}$ & $\begin{array}{r}1.093 \\
.002\end{array}$ & $\begin{array}{l}12593.18 \\
23665.85\end{array}$ & $\begin{array}{l}12610.15 \\
25142.45\end{array}$ & $\begin{array}{l}126.1 \\
191.4\end{array}$ & $\begin{array}{l}37.07 \\
29.09\end{array}$ & $\begin{array}{l}70.04 \\
40.81\end{array}$ & $\begin{array}{r}1137 \\
260\end{array}$ \\
\hline 193. & .33787 & $\begin{array}{l}18.976 \\
.22820\end{array}$ & $\begin{array}{r}19.882 \\
1.355\end{array}$ & $\begin{array}{r}1.080 \\
.002\end{array}$ & $\begin{array}{l}12662.78 \\
23683.50\end{array}$ & $\begin{array}{l}12680.59 \\
25164.06\end{array}$ & $\begin{array}{l}125.4 \\
191.1\end{array}$ & $\begin{array}{l}37.04 \\
29.19\end{array}$ & $\begin{array}{l}70.17 \\
41.03\end{array}$ & $\begin{array}{r}112 \\
261\end{array}$ \\
\hline 194. & .35308 & $\begin{array}{l}18.920 \\
.23786\end{array}$ & $\begin{array}{r}19.572 \\
1.355\end{array}$ & $\begin{array}{r}1.068 \\
.002\end{array}$ & $\begin{array}{l}12732.49 \\
23700.98\end{array}$ & $\begin{array}{l}12751.15 \\
25185.38\end{array}$ & $\begin{array}{l}126.8 \\
190.9\end{array}$ & $\begin{array}{l}37.01 \\
29.30\end{array}$ & $\begin{array}{l}70.30 \\
41.265\end{array}$ & $\begin{array}{r}1121 . \\
261 .\end{array}$ \\
\hline 195. & .36379 & $\begin{array}{l}19.863 \\
.24782\end{array}$ & $\begin{array}{r}18.265 \\
1.354\end{array}$ & $\begin{array}{r}1.056 \\
.002\end{array}$ & $\begin{array}{l}12802.30 \\
23718.27\end{array}$ & $\begin{array}{l}12821.86 \\
25206.40\end{array}$ & $\begin{array}{l}127.2 \\
190.7\end{array}$ & $\begin{array}{l}36.99 \\
29.40\end{array}$ & $\begin{array}{l}70.43 \\
41.50\end{array}$ & $\begin{array}{r}1113 . \\
261 .\end{array}$ \\
\hline 196. & .38502 & $\begin{array}{l}18.806 \\
.25811\end{array}$ & $\begin{array}{r}17.960 \\
1.353\end{array}$ & $\begin{array}{r}1.044 \\
.002\end{array}$ & $\begin{array}{l}12872.23 \\
23735.37\end{array}$ & $\begin{array}{l}12892.70 \\
25227.13\end{array}$ & $\begin{array}{l}127.5 \\
190.5\end{array}$ & $\begin{array}{l}36.97 \\
29.51\end{array}$ & $\begin{array}{l}70.57 \\
41.74\end{array}$ & $\begin{array}{r}1105 \\
261\end{array}$ \\
\hline 197. & .40178 & $\begin{array}{l}18.749 \\
.26870\end{array}$ & $\begin{array}{r}17.659 \\
1.351\end{array}$ & $\begin{array}{r}1.031 \\
.002\end{array}$ & $\begin{array}{r}12942.26 \\
23752.29\end{array}$ & $\begin{array}{l}12963.69 \\
25247.55\end{array}$ & $\begin{array}{l}127.9 \\
190.3\end{array}$ & $\begin{array}{l}36.95 \\
29.51\end{array}$ & $\begin{array}{l}70.72 \\
41.98\end{array}$ & $\begin{array}{c}1098 \\
261\end{array}$ \\
\hline 198. & .41907 & $\begin{array}{l}18.691 \\
.27964\end{array}$ & $\begin{array}{r}17.357 \\
1.350\end{array}$ & $\begin{array}{r}1.019 \\
.003\end{array}$ & $\begin{array}{l}13012.42 \\
23769.02\end{array}$ & $\begin{array}{l}13034.84 \\
25267.66\end{array}$ & $\begin{array}{l}128.2 \\
190.0\end{array}$ & $\begin{array}{l}36.93 \\
29.72\end{array}$ & $\begin{array}{l}70.86 \\
42.23\end{array}$ & $\begin{array}{c}1090 \\
261\end{array}$ \\
\hline 199. & .43691 & $\begin{array}{l}19.633 \\
.29091\end{array}$ & $\begin{array}{r}17.059 \\
1.348\end{array}$ & $\begin{array}{r}1.007 \\
.003\end{array}$ & $\begin{array}{l}13082.69 \\
23785.55\end{array}$ & $\begin{array}{l}13105.14 \\
25237.45\end{array}$ & $\begin{array}{l}128.6 \\
189.8\end{array}$ & $\begin{array}{l}36.92 \\
29.83\end{array}$ & $\begin{array}{l}71.02 \\
42.49\end{array}$ & $\begin{array}{r}1082 \\
262\end{array}$ \\
\hline 200. & .45531 & $\begin{array}{l}19.575 \\
.30252\end{array}$ & $\begin{array}{r}16.764 \\
1.346\end{array}$ & $\begin{array}{l}.996 \\
.003\end{array}$ & $\begin{array}{l}13153.08 \\
23801.88\end{array}$ & $\begin{array}{l}13177.59 \\
25306.92\end{array}$ & $\begin{array}{l}128.9 \\
189.6\end{array}$ & $\begin{array}{l}36.90 \\
29.94\end{array}$ & $\begin{array}{l}71.18 \\
42.75\end{array}$ & $\begin{array}{r}1074 \\
262\end{array}$ \\
\hline 201. & .47428 & $\begin{array}{l}18.517 \\
.31449\end{array}$ & $\begin{array}{r}15.470 \\
1.344\end{array}$ & $\begin{array}{l}.984 \\
.003\end{array}$ & $\begin{array}{l}13223.60 \\
23813.00\end{array}$ & $\begin{array}{l}13249.21 \\
25326.07\end{array}$ & $\begin{array}{l}129.3 \\
189.4\end{array}$ & $\begin{array}{l}36.89 \\
30.06\end{array}$ & $\begin{array}{l}71.34 \\
43.02\end{array}$ & $\begin{array}{r}1066 \\
262\end{array}$ \\
\hline 202. & .49382 & $\begin{array}{l}19.458 \\
.32683\end{array}$ & $\begin{array}{r}16.179 \\
1.341\end{array}$ & $\begin{array}{l}.972 \\
.003\end{array}$ & $\begin{array}{l}13294.25 \\
23833.92\end{array}$ & $\begin{array}{l}13321.01 \\
25344.88\end{array}$ & $\begin{array}{l}129.6 \\
189.2\end{array}$ & $\begin{array}{l}35.88 \\
30.17\end{array}$ & $\begin{array}{l}71.51 \\
43.30\end{array}$ & $\begin{array}{r}1057 \\
262\end{array}$ \\
\hline 203. & .51395 & $\begin{array}{l}18.399 \\
.33953\end{array}$ & $\begin{array}{r}15.890 \\
1.338\end{array}$ & $\begin{array}{l}.960 \\
.003\end{array}$ & $\begin{array}{l}13365.04 \\
23849.62\end{array}$ & $\begin{array}{l}13392.97 \\
25353.35\end{array}$ & $\begin{array}{l}130.0 \\
189.0\end{array}$ & $\begin{array}{l}36.87 \\
30.28\end{array}$ & $\begin{array}{l}71.68 \\
43.58\end{array}$ & $\begin{array}{r}1049 \\
262\end{array}$ \\
\hline 204 . & .53469 & $\begin{array}{l}18.340 \\
.35251\end{array}$ & $\begin{array}{r}15.602 \\
1.335\end{array}$ & $\begin{array}{l}.949 \\
.003\end{array}$ & $\begin{array}{l}13435.96 \\
23865.11\end{array}$ & $\begin{array}{l}13465.11 \\
25381.47\end{array}$ & $\begin{array}{l}130.3 \\
188.8\end{array}$ & $\begin{array}{l}36.87 \\
30.40\end{array}$ & $\begin{array}{l}71.86 \\
43.87\end{array}$ & $\begin{array}{r}1041 \\
262\end{array}$ \\
\hline 205. & .55603 & $\begin{array}{l}18.280 \\
.36508\end{array}$ & $\begin{array}{r}15.317 \\
1.332\end{array}$ & $\begin{array}{l}.937 \\
.003\end{array}$ & $\begin{array}{l}13507.03 \\
23880.37\end{array}$ & $\begin{array}{l}13537.44 \\
25399.24\end{array}$ & $\begin{array}{l}130.7 \\
188.5\end{array}$ & $\begin{array}{l}36.86 \\
30.52\end{array}$ & $\begin{array}{l}72.05 \\
44.17\end{array}$ & $\begin{array}{r}1033 \\
262\end{array}$ \\
\hline 206. & .57300 & $\begin{array}{l}13.220 \\
.37995\end{array}$ & $\begin{array}{r}15.054 \\
1.328\end{array}$ & $\begin{array}{l}.926 \\
.004\end{array}$ & $\begin{array}{l}13578.24 \\
23895.41\end{array}$ & $\begin{array}{l}13609.96 \\
25416.65\end{array}$ & $\begin{array}{l}131.0 \\
188.4\end{array}$ & $\begin{array}{l}36.86 \\
30.64\end{array}$ & $\begin{array}{l}72.24 \\
44.47\end{array}$ & $\begin{array}{r}1025 \\
262\end{array}$ \\
\hline 207 & .50059 & $\begin{array}{l}13.150 \\
.39422\end{array}$ & $\begin{array}{r}14.752 \\
1.325\end{array}$ & $\begin{array}{l}.915 \\
.004\end{array}$ & $\begin{array}{l}13649.51 \\
23910.21\end{array}$ & $\begin{array}{l}13682.68 \\
25433.70\end{array}$ & $\begin{array}{l}131.4 \\
188.2\end{array}$ & $\begin{array}{l}36.86 \\
30.76\end{array}$ & $\begin{array}{l}72.45 \\
44.79\end{array}$ & $\begin{array}{l}1017 . \\
262 .\end{array}$ \\
\hline 208 . & .52383 & $\begin{array}{l}18.099 \\
.40891\end{array}$ & $\begin{array}{c}14.473 \\
1.321\end{array}$ & $\begin{array}{l}.903 \\
.004\end{array}$ & $\begin{array}{l}13721.13 \\
23924.78\end{array}$ & $\begin{array}{l}13755.60 \\
25450.37\end{array}$ & $\begin{array}{l}131.7 \\
188.0\end{array}$ & $\begin{array}{l}36.86 \\
30.88\end{array}$ & $\begin{array}{l}72.65 \\
45.11\end{array}$ & $\begin{array}{l}1008 . \\
262 .\end{array}$ \\
\hline 209. & .64772 & $\begin{array}{l}18.038 \\
.42403\end{array}$ & $\begin{array}{r}14.196 \\
1.316\end{array}$ & $\begin{array}{l}.892 \\
.004\end{array}$ & $\begin{array}{l}13792.81 \\
23939.10\end{array}$ & $\begin{array}{l}13828.72 \\
25466.66\end{array}$ & $\begin{array}{r}132.1 \\
187.9\end{array}$ & $\begin{array}{l}36.86 \\
31.01\end{array}$ & $\begin{array}{l}72.87 \\
45.43\end{array}$ & $\begin{array}{r}1000 . \\
262 \text {. }\end{array}$ \\
\hline 210. & .57228 & $\begin{array}{l}17.977 \\
.43358\end{array}$ & $\begin{array}{r}13.920 \\
1.312\end{array}$ & $\begin{array}{l}.981 \\
.004\end{array}$ & $\begin{array}{l}13864.57 \\
23953.18\end{array}$ & $\begin{array}{l}13902.05 \\
25482.56\end{array}$ & $\begin{array}{l}132.4 \\
187.6\end{array}$ & $\begin{array}{l}36.86 \\
31.13\end{array}$ & $\begin{array}{l}73.09 \\
45.77\end{array}$ & $\begin{array}{l}992 . \\
262 .\end{array}$ \\
\hline 211. & .59751 & $\begin{array}{l}17.915 \\
.45557\end{array}$ & $\begin{array}{r}13.546 \\
1.307\end{array}$ & $\begin{array}{l}.870 \\
.004\end{array}$ & $\begin{array}{l}13956.50 \\
23967.00\end{array}$ & $\begin{array}{l}13975.62 \\
2549.06\end{array}$ & $\begin{array}{l}132.8 \\
187.4\end{array}$ & $\begin{array}{l}36.97 \\
31.26\end{array}$ & $\begin{array}{l}73.32 \\
46.12\end{array}$ & $\begin{array}{l}984 . \\
262 .\end{array}$ \\
\hline
\end{tabular}


Table B-1. (Continued)

\begin{tabular}{|c|c|c|c|c|c|c|c|c|c|c|}
\hline$\underset{k}{\operatorname{Temp}}$. & $\begin{array}{l}\text { Pressure } \\
\text { MPa }\end{array}$ & $\begin{array}{l}\text { Density } \\
\mathrm{mol} / \mathrm{dm} 3\end{array}$ & $\begin{array}{l}\text { I sothern } \\
\text { Der Ivative } \\
\mathrm{dm}^{3} \text {-Ma/mol }\end{array}$ & $\begin{array}{c}\text { I sochore } \\
\text { Der ivative } \\
\mathrm{MPa} / K\end{array}$ & $\begin{array}{l}\text { Internal } \\
\text { Energv } \\
\text { J/mol }\end{array}$ & $\begin{array}{c}\text { Enthalpy } \\
J / m o l\end{array}$ & $\begin{array}{c}\text { Entropy } \\
J /(\text { mol } \cdot k)\end{array}$ & $\begin{array}{l}c_{V} \\
J /(m c\end{array}$ & ${ }^{C_{p}}$ & $\begin{array}{c}\text { Velo: }:+y \\
\text { of sound } \\
\mathrm{m} / \mathrm{s}\end{array}$ \\
\hline 212 & .72343 & $\begin{array}{l}17.853 \\
.47203\end{array}$ & $\begin{array}{r}13.374 \\
1.302\end{array}$ & $\begin{array}{l}.859 \\
.005\end{array}$ & $\begin{array}{l}14008.89 \\
23980.57\end{array}$ & $\begin{array}{l}14049.41 \\
25513.16\end{array}$ & $\begin{array}{l}133.1 \\
18 \% .2\end{array}$ & $\begin{array}{l}36.88 \\
31.39\end{array}$ & $\begin{array}{l}73.56 \\
46.47\end{array}$ & $\begin{array}{l}975 . \\
262 .\end{array}$ \\
\hline 213. & .75004 & $\begin{array}{r}17.791 \\
.48895\end{array}$ & $\begin{array}{r}13.104 \\
1.296\end{array}$ & $\begin{array}{l}.848 \\
.005\end{array}$ & $\begin{array}{l}14031.28 \\
23993.37\end{array}$ & $\begin{array}{l}14123.44 \\
25527.85\end{array}$ & $\begin{array}{l}133.4 \\
187.0\end{array}$ & $\begin{array}{l}36.89 \\
31.52\end{array}$ & $\begin{array}{l}73.80 \\
45.84\end{array}$ & $\begin{array}{l}967 . \\
262 .\end{array}$ \\
\hline 214 & .77736 & $\begin{array}{l}17.728 \\
.50635\end{array}$ & $\begin{array}{r}12.835 \\
1.291\end{array}$ & $\begin{array}{l}.837 \\
.005\end{array}$ & $\begin{array}{l}14153.86 \\
24006.39\end{array}$ & $\begin{array}{l}14197.71 \\
25542.11\end{array}$ & $\begin{array}{l}133.8 \\
186.8\end{array}$ & $\begin{array}{l}36.90 \\
31.65\end{array}$ & $\begin{array}{l}74.06 \\
47.22\end{array}$ & $\begin{array}{l}958 . \\
262 .\end{array}$ \\
\hline 215. & .80540 & $\begin{array}{l}17.665 \\
.52425\end{array}$ & $\begin{array}{r}12.569 \\
1.285\end{array}$ & $\begin{array}{l}.826 \\
.005\end{array}$ & $\begin{array}{l}14226.63 \\
24019.54\end{array}$ & $\begin{array}{l}14272.23 \\
25555.95\end{array}$ & $\begin{array}{l}134.1 \\
136.6\end{array}$ & $\begin{array}{l}35.91 \\
31.78\end{array}$ & $\begin{array}{l}74.32 \\
47.60\end{array}$ & $\begin{array}{l}950 . \\
262 .\end{array}$ \\
\hline 216 & .83417 & $\begin{array}{l}17.601 \\
.54264\end{array}$ & $\begin{array}{r}12.304 \\
1.278\end{array}$ & $\begin{array}{l}.815 \\
.005\end{array}$ & $\begin{array}{l}14299.61 \\
24032.10\end{array}$ & $\begin{array}{l}14347.00 \\
25569.34\end{array}$ & $\begin{array}{l}134.5 \\
186.4\end{array}$ & $\begin{array}{l}35.92 \\
31.92\end{array}$ & $\begin{array}{l}74.60 \\
48.00\end{array}$ & $\begin{array}{l}941 . \\
262 .\end{array}$ \\
\hline 217 & .86368 & $\begin{array}{r}17.537 \\
.56156\end{array}$ & $\begin{array}{r}12.041 \\
1.272\end{array}$ & $\begin{array}{l}.805 \\
.005\end{array}$ & $\begin{array}{l}14372.80 \\
24044.27\end{array}$ & $\begin{array}{l}14422.05 \\
25582.29\end{array}$ & $\begin{array}{l}134.8 \\
186.2\end{array}$ & $\begin{array}{l}36.94 \\
32.05\end{array}$ & $\begin{array}{l}74.88 \\
48.41\end{array}$ & $\begin{array}{l}933 . \\
262 .\end{array}$ \\
\hline 218 & .89395 & $\begin{array}{r}17.472 \\
.58100\end{array}$ & $\begin{array}{r}11.780 \\
1.265\end{array}$ & $\begin{array}{l}.794 \\
.006\end{array}$ & $\begin{array}{l}14445.20 \\
24055.15\end{array}$ & $\begin{array}{l}14497.36 \\
25594.77\end{array}$ & $\begin{array}{l}135.1 \\
186.1\end{array}$ & $\begin{array}{l}36.96 \\
32.19\end{array}$ & $\begin{array}{l}75.18 \\
48.83\end{array}$ & $\begin{array}{l}924 . \\
262 .\end{array}$ \\
\hline 219 & .92497 & $\begin{array}{r}17.407 \\
.60099\end{array}$ & $\begin{array}{r}11.521 \\
1.258\end{array}$ & $\begin{array}{l}.783 \\
.006\end{array}$ & $\begin{array}{l}14519.33 \\
24067.71\end{array}$ & $\begin{array}{l}14572.97 \\
25606.79\end{array}$ & $\begin{array}{l}135.5 \\
185.9\end{array}$ & $\begin{array}{l}36.98 \\
32.33\end{array}$ & $\begin{array}{l}75.49 \\
49.26\end{array}$ & $\begin{array}{l}915 . \\
261 .\end{array}$ \\
\hline 220 & .95678 & $\begin{array}{l}17.342 \\
.52154\end{array}$ & $\begin{array}{r}11.263 \\
1.250\end{array}$ & $\begin{array}{l}.773 \\
.006\end{array}$ & $\begin{array}{l}14593.69 \\
24078.96\end{array}$ & $\begin{array}{l}14648.86 \\
25619.33\end{array}$ & $\begin{array}{l}135.8 \\
185.7\end{array}$ & $\begin{array}{l}37.00 \\
32.47\end{array}$ & $\begin{array}{l}75.80 \\
49.71\end{array}$ & $\begin{array}{l}907 . \\
261 .\end{array}$ \\
\hline 221 & .08937 & $\begin{array}{l}17.276 \\
.64266\end{array}$ & $\begin{array}{r}11.007 \\
1.242\end{array}$ & $\begin{array}{l}.762 \\
.006\end{array}$ & $\begin{array}{l}14667.79 \\
24089.88\end{array}$ & $\begin{array}{l}14725.05 \\
25529.37\end{array}$ & $\begin{array}{l}136.2 \\
185.5\end{array}$ & $\begin{array}{l}37.02 \\
32.51\end{array}$ & $\begin{array}{l}75.13 \\
50.17\end{array}$ & $\begin{array}{l}898 . \\
261 .\end{array}$ \\
\hline 222 & 1.0228 & $\begin{array}{l}17.209 \\
.66436\end{array}$ & $\begin{array}{r}10.753 \\
1.234\end{array}$ & $\begin{array}{l}.752 \\
.007\end{array}$ & $\begin{array}{l}14742.13 \\
24100.47\end{array}$ & $\begin{array}{l}14801.56 \\
25639.91\end{array}$ & $\begin{array}{l}136.5 \\
185.3\end{array}$ & $\begin{array}{l}37.05 \\
32.76\end{array}$ & $\begin{array}{l}76.47 \\
50.65\end{array}$ & $\begin{array}{l}890 . \\
261 .\end{array}$ \\
\hline 223. & 1.0569 & $\begin{array}{r}17.142 \\
.58668\end{array}$ & $\begin{array}{r}10.501 \\
1.226\end{array}$ & .742 & $\begin{array}{l}14815.73 \\
24110.72\end{array}$ & $\begin{array}{l}14879.39 \\
25649.94\end{array}$ & $\begin{array}{l}136.8 \\
185.1\end{array}$ & $\begin{array}{l}37.07 \\
32.91\end{array}$ & $\begin{array}{l}76.83 \\
51.14\end{array}$ & $\begin{array}{l}891 . \\
261 .\end{array}$ \\
\hline 224. & 1.0920 & $\begin{array}{l}17.075 \\
.70961\end{array}$ & $\begin{array}{r}10.251 \\
1.217\end{array}$ & $\begin{array}{l}.731 \\
.007\end{array}$ & $\begin{array}{l}14891.60 \\
24120.51\end{array}$ & $\begin{array}{l}14955.55 \\
25659.44\end{array}$ & $\begin{array}{l}137.2 \\
185.0\end{array}$ & $\begin{array}{l}37.10 \\
33.0 t\end{array}$ & $\begin{array}{l}77.2 \mathrm{C} \\
51.64\end{array}$ & $\begin{array}{l}872 . \\
260 .\end{array}$ \\
\hline 225. & 1.1278 & $\begin{array}{l}17.006 \\
.73313\end{array}$ & $\begin{array}{r}10.002 \\
1.208\end{array}$ & $\begin{array}{l}.721 \\
.007\end{array}$ & $\begin{array}{l}14960.74 \\
24130.15\end{array}$ & $\begin{array}{l}15033.05 \\
25668.40\end{array}$ & $\begin{array}{l}137.5 \\
134.5\end{array}$ & $\begin{array}{l}37.13 \\
33.21\end{array}$ & $\begin{array}{l}77.58 \\
52.16\end{array}$ & $\begin{array}{l}863 . \\
260 .\end{array}$ \\
\hline 226 . & 1.1645 & $\begin{array}{l}15.938 \\
.75741\end{array}$ & $\begin{array}{l}9.755 \\
1.199\end{array}$ & $\begin{array}{l}.711 \\
.008\end{array}$ & $\begin{array}{l}15042.16 \\
24139.31\end{array}$ & $\begin{array}{l}15110.91 \\
25675.90\end{array}$ & $\begin{array}{l}137.8 \\
134.5\end{array}$ & $\begin{array}{l}37.17 \\
33.36\end{array}$ & $\begin{array}{l}77.98 \\
52.70\end{array}$ & $\begin{array}{l}854 . \\
260 .\end{array}$ \\
\hline 227 & 1.2021 & $\begin{array}{l}16.368 \\
.79231\end{array}$ & $\begin{array}{l}9.511 \\
1.189\end{array}$ & $\begin{array}{l}.70 ! \\
.008\end{array}$ & $\begin{array}{l}15117.37 \\
24148.10\end{array}$ & $\begin{array}{l}15139.13 \\
25684.64\end{array}$ & $\begin{array}{l}138.2 \\
184.4\end{array}$ & $\begin{array}{l}37.20 \\
33.51\end{array}$ & $\begin{array}{l}73.39 \\
53.26\end{array}$ & $\begin{array}{l}945 . \\
260 .\end{array}$ \\
\hline 228. & 1.2405 & $\begin{array}{l}15.798 \\
.80791\end{array}$ & $\begin{array}{l}9.258 \\
1.179\end{array}$ & $\begin{array}{l}.691 \\
.008\end{array}$ & $\begin{array}{l}15193.38 \\
24155.48\end{array}$ & $\begin{array}{l}15257.73 \\
25691.80\end{array}$ & $\begin{array}{l}138.5 \\
184.2\end{array}$ & $\begin{array}{l}37.24 \\
33.67\end{array}$ & $\begin{array}{l}78.82 \\
53.84\end{array}$ & $\begin{array}{l}336 . \\
259 .\end{array}$ \\
\hline 229. & 1.2798 & $\begin{array}{r}15.728 \\
.83422\end{array}$ & $\begin{array}{l}9.227 \\
1.169\end{array}$ & $\begin{array}{l}.681 \\
.009\end{array}$ & $\begin{array}{l}15270.21 \\
24164.47\end{array}$ & $\begin{array}{l}15345.72 \\
25699.55\end{array}$ & $\begin{array}{l}138.8 \\
184.0\end{array}$ & $\begin{array}{l}37.28 \\
33.93\end{array}$ & $\begin{array}{l}79.25 \\
54.44\end{array}$ & $\begin{array}{l}827 . \\
259 .\end{array}$ \\
\hline 230 . & 1.3199 & $\begin{array}{l}15.556 \\
.86127\end{array}$ & $\begin{array}{l}8.798 \\
1.159\end{array}$ & $\begin{array}{l}.570 \\
.009\end{array}$ & $\begin{array}{l}15346.86 \\
24172.03\end{array}$ & $\begin{array}{l}15425.11 \\
.5704 .59\end{array}$ & $\begin{array}{l}139.2 \\
193.9\end{array}$ & $\begin{array}{l}37.32 \\
33.99\end{array}$ & $\begin{array}{l}79.73 \\
55.06\end{array}$ & $\begin{array}{l}813 . \\
259 .\end{array}$ \\
\hline 231. & 1.3610 & $\begin{array}{l}15.584 \\
.89908\end{array}$ & $\begin{array}{l}3.551 \\
1.147\end{array}$ & $\begin{array}{l}.560 \\
.009\end{array}$ & $\begin{array}{l}15423.84 \\
24179.16\end{array}$ & $\begin{array}{l}15505.91 \\
25710.00\end{array}$ & $\begin{array}{l}139.5 \\
193.7\end{array}$ & $\begin{array}{l}37.36 \\
34.15\end{array}$ & $\begin{array}{l}80.21 \\
55.70\end{array}$ & $\begin{array}{l}809 . \\
259 .\end{array}$ \\
\hline 232 . & 1.4030 & $\begin{array}{l}16.512 \\
.91767\end{array}$ & $\begin{array}{l}8.316 \\
1.135\end{array}$ & $\begin{array}{l}.551 \\
.010\end{array}$ & $\begin{array}{l}15501.17 \\
24185.85\end{array}$ & $\begin{array}{l}15586.14 \\
25714.76\end{array}$ & $\begin{array}{l}139.9 \\
183.5\end{array}$ & $\begin{array}{l}37.40 \\
34.32\end{array}$ & $\begin{array}{l}80.71 \\
55.37\end{array}$ & $\begin{array}{l}800 . \\
258 .\end{array}$ \\
\hline 233. & 1.4460 & $\begin{array}{l}16.438 \\
.94707\end{array}$ & $\begin{array}{l}8.084 \\
1.124\end{array}$ & $\begin{array}{l}.641 \\
.210\end{array}$ & $\begin{array}{l}15579.86 \\
24192.08\end{array}$ & $\begin{array}{l}15666.82 \\
25719.85\end{array}$ & $\begin{array}{l}140.2 \\
183.3\end{array}$ & $\begin{array}{l}37.45 \\
34.49\end{array}$ & $\begin{array}{l}81.23 \\
57.07\end{array}$ & $\begin{array}{l}791 . \\
257 .\end{array}$ \\
\hline
\end{tabular}


Table B-1. (Continued)

\begin{tabular}{|c|c|c|c|c|c|c|c|c|c|c|}
\hline$\underset{K}{T e m p .}$ & $\begin{array}{l}\text { Pressure } \\
\text { MPO }\end{array}$ & $\begin{array}{l}\text { Density } \\
\mathrm{mol} / \mathrm{dm} 3\end{array}$ & $\begin{array}{l}\text { I sotherm } \\
\text { Der Ivative } \\
\text { dm 3-MPa/mo! }\end{array}$ & $\begin{array}{c}\text { I sochore } \\
\text { Der ivat I ve } \\
\text { MPa/K }\end{array}$ & $\begin{array}{l}\text { Internal } \\
\text { Energy } \\
\text { J/mol }\end{array}$ & $\begin{array}{c}\text { Enthalpy } \\
\mathrm{J} / \mathrm{mol}\end{array}$ & $\begin{array}{c}\text { Entropy } \\
\mathrm{J} /(\mathrm{mol} \cdot \mathrm{K})\end{array}$ & $\begin{array}{l}C_{V} \\
J / C m\end{array}$ & $(\cdot \cdot k)^{C_{p}}$ & $\begin{array}{c}\text { Velocity } \\
\text { of sound } \\
\mathrm{m} / \mathrm{s}\end{array}$ \\
\hline 234. & 1.4898 & $\begin{array}{l}16.364 \\
.97731\end{array}$ & $\begin{array}{l}7.853 \\
1.112\end{array}$ & $\begin{array}{l}.631 \\
.010\end{array}$ & $\begin{array}{l}15655.92 \\
24197.83\end{array}$ & $\begin{array}{l}15747.96 \\
25722.26\end{array}$ & $\begin{array}{l}140.5 \\
183.1\end{array}$ & $\begin{array}{l}37.50 \\
34.66\end{array}$ & $\begin{array}{l}81.77 \\
57.79\end{array}$ & $\begin{array}{l}781 . \\
257 .\end{array}$ \\
\hline 235. & 1.5347 & $\begin{array}{l}16.289 \\
1.0084\end{array}$ & $\begin{array}{l}7.624 \\
1.100\end{array}$ & $\begin{array}{l}.621 \\
.011\end{array}$ & $\begin{array}{l}15735.36 \\
24203.10\end{array}$ & $\begin{array}{l}15929.57 \\
25724.96\end{array}$ & $\begin{array}{l}140.9 \\
183.0\end{array}$ & $\begin{array}{l}37.55 \\
34.83\end{array}$ & $\begin{array}{l}82.34 \\
58.54\end{array}$ & $\begin{array}{l}772 . \\
257 .\end{array}$ \\
\hline 236. & 1.5804 & $\begin{array}{l}16.213 \\
1.0404\end{array}$ & $\begin{array}{l}7.398 \\
1.087\end{array}$ & .011 & $\begin{array}{l}15814.19 \\
24207.85\end{array}$ & $\begin{array}{l}15911.68 \\
25726.92\end{array}$ & $\begin{array}{l}141.2 \\
182.8\end{array}$ & $\begin{array}{l}37.61 \\
35.01\end{array}$ & $\begin{array}{l}82.93 \\
59.32\end{array}$ & $\begin{array}{l}763 . \\
256 .\end{array}$ \\
\hline 237. & 1.6272 & $\begin{array}{l}16.136 \\
1.0733\end{array}$ & $\begin{array}{l}7.173 \\
1.074\end{array}$ & $\begin{array}{l}.601 \\
.011\end{array}$ & $\begin{array}{l}15893.44 \\
24212.08\end{array}$ & $\begin{array}{l}15994.29 \\
25728.14\end{array}$ & $\begin{array}{l}141.5 \\
182.6\end{array}$ & $\begin{array}{l}37.66 \\
35.18\end{array}$ & $\begin{array}{l}83.55 \\
60.14\end{array}$ & $\begin{array}{l}753 . \\
256 .\end{array}$ \\
\hline 238. & 1.6750 & $\begin{array}{l}15.058 \\
1.1072\end{array}$ & $\begin{array}{l}6.951 \\
1.060\end{array}$ & $\begin{array}{l}.592 \\
.012\end{array}$ & $\begin{array}{l}15973.12 \\
24215.77\end{array}$ & $\begin{array}{l}16077.42 \\
25728.59\end{array}$ & $\begin{array}{l}141.9 \\
182.4\end{array}$ & $\begin{array}{l}37.72 \\
35.36\end{array}$ & $\begin{array}{l}84.19 \\
60.99\end{array}$ & $\begin{array}{l}744 \\
255\end{array}$ \\
\hline 239. & 1.7237 & $\begin{array}{l}15.980 \\
1.1420\end{array}$ & $\begin{array}{l}6.731 \\
1.046\end{array}$ & $\begin{array}{l}.582 \\
.012\end{array}$ & $\begin{array}{l}16053.24 \\
24218.89\end{array}$ & $\begin{array}{l}16161.11 \\
25728.23\end{array}$ & $\begin{array}{l}142.2 \\
182.2\end{array}$ & $\begin{array}{l}37.78 \\
35.55\end{array}$ & $\begin{array}{l}84.86 \\
61.87\end{array}$ & $\begin{array}{l}734 . \\
255\end{array}$ \\
\hline 240 . & 1.7735 & $\begin{array}{l}15.900 \\
1.1779\end{array}$ & $\begin{array}{l}5.514 \\
1.032\end{array}$ & $\begin{array}{l}.572 \\
.013\end{array}$ & $\begin{array}{l}16133.81 \\
24221.43\end{array}$ & $\begin{array}{l}16245.35 \\
25727.05\end{array}$ & $\begin{array}{l}142.5 \\
182.1\end{array}$ & $\begin{array}{l}37.85 \\
35.73\end{array}$ & $\begin{array}{l}85.57 \\
62.80\end{array}$ & $\begin{array}{l}725 \text {. } \\
254 .\end{array}$ \\
\hline 241. & 1.8243 & $\begin{array}{l}15.819 \\
1.2149\end{array}$ & $\begin{array}{l}6.299 \\
1.018\end{array}$ & $\begin{array}{l}.563 \\
.013\end{array}$ & $\begin{array}{l}16214.86 \\
24223.36\end{array}$ & $\begin{array}{l}16330.18 \\
25725.01\end{array}$ & $\begin{array}{l}142.9 \\
181.9\end{array}$ & $\begin{array}{l}37.91 \\
35.92\end{array}$ & $\begin{array}{l}86.30 \\
63.77\end{array}$ & $\begin{array}{l}715 . \\
254 .\end{array}$ \\
\hline 242 . & 1.8761 & $\begin{array}{l}15.738 \\
1.2529\end{array}$ & $\begin{array}{l}6.086 \\
1.003\end{array}$ & $\begin{array}{l}.553 \\
.014\end{array}$ & $\begin{array}{l}16296.40 \\
24224.66\end{array}$ & $\begin{array}{l}16415.62 \\
25722.08\end{array}$ & $\begin{array}{l}143.2 \\
181.7\end{array}$ & $\begin{array}{l}37.98 \\
36.12\end{array}$ & $\begin{array}{l}87.07 \\
64.79\end{array}$ & $\begin{array}{l}705 . \\
253 .\end{array}$ \\
\hline 243. & 1.9290 & $\begin{array}{l}15.655 \\
1.2921\end{array}$ & $\begin{array}{r}5.876 \\
.987\end{array}$ & $\begin{array}{l}.543 \\
.014\end{array}$ & $\begin{array}{l}16379.46 \\
24225.31\end{array}$ & $\begin{array}{l}16501.68 \\
25718.25\end{array}$ & $\begin{array}{l}143.6 \\
181.5\end{array}$ & $\begin{array}{l}38.05 \\
36.31\end{array}$ & $\begin{array}{l}87.87 \\
65.86\end{array}$ & $\begin{array}{l}695 . \\
253 .\end{array}$ \\
\hline 244. & 1.9830 & $\begin{array}{l}15.571 \\
1.3325\end{array}$ & $\begin{array}{r}5.668 \\
.971\end{array}$ & $\begin{array}{l}.534 \\
.015\end{array}$ & $\begin{array}{l}16461.05 \\
24225.27\end{array}$ & $\begin{array}{l}16588.40 \\
25713.46\end{array}$ & $\begin{array}{l}143.9 \\
181.3\end{array}$ & $\begin{array}{l}38.13 \\
36.51\end{array}$ & $\begin{array}{l}88.72 \\
66.98\end{array}$ & $\begin{array}{l}686 . \\
252 .\end{array}$ \\
\hline 245. & 2.0380 & $\begin{array}{l}15.485 \\
1.3741\end{array}$ & $\begin{array}{r}5.463 \\
.955\end{array}$ & $\begin{array}{l}.524 \\
.015\end{array}$ & $\begin{array}{l}16544.19 \\
24224.52\end{array}$ & $\begin{array}{l}16675.79 \\
25707.69\end{array}$ & $\begin{array}{l}144.3 \\
181.1\end{array}$ & $\begin{array}{l}38.21 \\
36.71\end{array}$ & $\begin{array}{l}89.60 \\
68.16\end{array}$ & $\begin{array}{l}676 . \\
251 .\end{array}$ \\
\hline 246. & 2.0942 & $\begin{array}{l}15.399 \\
1.4170\end{array}$ & $\begin{array}{r}5.260 \\
.939\end{array}$ & $\begin{array}{l}.515 \\
.016\end{array}$ & $\begin{array}{l}16627.90 \\
24223.03\end{array}$ & $\begin{array}{l}16763.89 \\
25700.89\end{array}$ & $\begin{array}{l}144.6 \\
180.9\end{array}$ & $\begin{array}{l}38.29 \\
36.92\end{array}$ & $\begin{array}{l}90.53 \\
69.40\end{array}$ & $\begin{array}{l}666 . \\
25 i .\end{array}$ \\
\hline 247. & 2.1514 & $\begin{array}{l}15.312 \\
1.4613\end{array}$ & $\begin{array}{r}5.060 \\
.922\end{array}$ & $\begin{array}{l}.505 \\
.016\end{array}$ & $\begin{array}{l}16712.21 \\
24220.77\end{array}$ & $\begin{array}{l}16852.72 \\
25693.03\end{array}$ & $\begin{array}{l}144.9 \\
180.7\end{array}$ & $\begin{array}{l}38.38 \\
37.13\end{array}$ & $\begin{array}{l}91.51 \\
70.71\end{array}$ & $\begin{array}{l}656 . \\
250 .\end{array}$ \\
\hline 248. & 2.2098 & $\begin{array}{l}15.222 \\
1.5070\end{array}$ & $\begin{array}{r}4.863 \\
.905\end{array}$ & $\begin{array}{l}.496 \\
.017\end{array}$ & $\begin{array}{l}16797.14 \\
24217.70\end{array}$ & $\begin{array}{l}16942.31 \\
25684.07\end{array}$ & $\begin{array}{l}145.3 \\
180.5\end{array}$ & $\begin{array}{l}38.46 \\
37.35\end{array}$ & $\begin{array}{l}92.54 \\
72.10\end{array}$ & $\begin{array}{l}646 . \\
250 .\end{array}$ \\
\hline 249. & 2.2694 & $\begin{array}{l}15.132 \\
1.5542\end{array}$ & $\begin{array}{r}4.668 \\
.887\end{array}$ & $\begin{array}{l}.486 \\
.018\end{array}$ & $\begin{array}{l}16882.73 \\
24213.78\end{array}$ & $\begin{array}{l}17032.70 \\
25673.96\end{array}$ & $\begin{array}{l}145.6 \\
180.3\end{array}$ & $\begin{array}{l}38.56 \\
37.56\end{array}$ & $\begin{array}{l}93.63 \\
73.56\end{array}$ & $\begin{array}{l}636 \\
249\end{array}$ \\
\hline 250. & 2.3300 & $\begin{array}{l}15.040 \\
1.6029\end{array}$ & $\begin{array}{r}4.476 \\
.869\end{array}$ & $\begin{array}{l}.477 \\
.018\end{array}$ & $\begin{array}{l}16968.99 \\
24208.98\end{array}$ & $\begin{array}{l}17123.91 \\
25662.64\end{array}$ & $\begin{array}{l}146.0 \\
180.1\end{array}$ & $\begin{array}{l}38.65 \\
37.79\end{array}$ & $\begin{array}{l}94.78 \\
75.12\end{array}$ & $\begin{array}{l}625 . \\
248 .\end{array}$ \\
\hline 251. & 2.3919 & $\begin{array}{l}14.946 \\
1.6532\end{array}$ & $\begin{array}{r}4.287 \\
.850\end{array}$ & $\begin{array}{l}.467 \\
.019\end{array}$ & $\begin{array}{l}17055.95 \\
24203.25\end{array}$ & $\begin{array}{l}17215.99 \\
25650.08\end{array}$ & $\begin{array}{l}146.3 \\
179.9\end{array}$ & $\begin{array}{l}38.75 \\
38.01\end{array}$ & $\begin{array}{l}95.99 \\
76.77\end{array}$ & $\begin{array}{l}615 . \\
247\end{array}$ \\
\hline 252. & 2.4549 & $\begin{array}{l}14.951 \\
1.7052\end{array}$ & $\begin{array}{r}4.101 \\
.831\end{array}$ & $\begin{array}{l}.458 \\
.020\end{array}$ & $\begin{array}{l}17143.66 \\
24196.55\end{array}$ & $\begin{array}{l}17308.96 \\
25636.20\end{array}$ & $\begin{array}{l}146.7 \\
179.7\end{array}$ & $\begin{array}{l}38.86 \\
38.25\end{array}$ & $\begin{array}{l}97.27 \\
78.52\end{array}$ & $\begin{array}{l}605 . \\
247\end{array}$ \\
\hline 253. & 2.5192 & $\begin{array}{l}14.754 \\
1.7590\end{array}$ & $\begin{array}{r}3.917 \\
.812\end{array}$ & $\begin{array}{l}.448 \\
.020\end{array}$ & $\begin{array}{l}17232.13 \\
24188.82\end{array}$ & $\begin{array}{l}17402.88 \\
25620.95\end{array}$ & $\begin{array}{l}147.0 \\
179.5\end{array}$ & $\begin{array}{l}38.97 \\
38.48\end{array}$ & $\begin{array}{l}98.64 \\
80.39\end{array}$ & $\begin{array}{l}595 . \\
246 .\end{array}$ \\
\hline 254 . & 2.5846 & $\begin{array}{l}14.655 \\
1.8147\end{array}$ & $\begin{array}{r}3.737 \\
.792\end{array}$ & $\begin{array}{l}.439 \\
.021\end{array}$ & $\begin{array}{l}17321.42 \\
24180.01\end{array}$ & $\begin{array}{l}17497.78 \\
25604.26\end{array}$ & $\begin{array}{l}147.4 \\
179.3\end{array}$ & $\begin{array}{l}39.08 \\
38.72\end{array}$ & $\begin{array}{r}100.09 \\
82.39\end{array}$ & $\begin{array}{l}584 . \\
245 .\end{array}$ \\
\hline 255. & 2.6513 & $\begin{array}{l}14.554 \\
1.8724\end{array}$ & $\begin{array}{r}3.559 \\
.772\end{array}$ & $\begin{array}{l}.430 \\
.022\end{array}$ & $\begin{array}{l}17411.56 \\
24170.07\end{array}$ & $\begin{array}{l}17593.72 \\
25586.06\end{array}$ & $\begin{array}{l}147.8 \\
179.1\end{array}$ & $\begin{array}{l}39.20 \\
38.97\end{array}$ & $\begin{array}{r}101.63 \\
84.53\end{array}$ & $\begin{array}{l}574 \\
244\end{array}$ \\
\hline
\end{tabular}


Table 8-1. (Continued)

\begin{tabular}{|c|c|c|c|c|c|c|c|c|c|c|}
\hline$\underset{k}{T e m p}$ & $\begin{array}{l}\text { Pressure } \\
\mathrm{MPa}\end{array}$ & $\begin{array}{l}\text { Density } \\
\mathrm{mol}^{\prime} / \mathrm{dm}^{3}\end{array}$ & $\begin{array}{l}\text { Isotherm } \\
\text { Derlvative } \\
\text { an } 3-\mathrm{MPa} / \mathrm{mol}\end{array}$ & $\begin{array}{c}\text { I sochore } \\
\text { Derivative } \\
\text { IPaK }\end{array}$ & $\begin{array}{l}\text { Internal } \\
\text { Energy } \\
\text { J'riol }\end{array}$ & $\begin{array}{c}\text { Enthalpy } \\
\text { J/mol }\end{array}$ & $\begin{array}{l}\text { Entropy } \\
\mathrm{J} /(\operatorname{mo} ! \cdot \mathrm{K})\end{array}$ & \multicolumn{2}{|c|}{$\begin{array}{l}C_{V} \quad C_{p} \\
J /(\operatorname{mol} \cdot k)^{-}\end{array}$} & $\begin{array}{l}\text { Velocity } \\
\text { of sound } \\
\mathrm{m} / \mathrm{s}\end{array}$ \\
\hline 256. & 2.7192 & $\begin{array}{l}14.451 \\
1.9322\end{array}$ & $\begin{array}{r}3.385 \\
.751\end{array}$ & $\begin{array}{l}.420 \\
.023\end{array}$ & $\begin{array}{l}17502.59 \\
24158.92\end{array}$ & $\begin{array}{l}17690.75 \\
25566.26\end{array}$ & $\begin{array}{l}148.1 \\
178.9\end{array}$ & $\begin{array}{l}39.32 \\
39.22\end{array}$ & $\begin{array}{r}103.28 \\
86.83\end{array}$ & $\begin{array}{l}563 . \\
243 .\end{array}$ \\
\hline 257. & 2.7884 & $\begin{array}{l}14.346 \\
1.9942\end{array}$ & $\begin{array}{r}3.214 \\
.730\end{array}$ & $\begin{array}{l}.411 \\
.024\end{array}$ & $\begin{array}{l}17594.55 \\
24146.50\end{array}$ & $\begin{array}{l}17788.92 \\
25544.90\end{array}$ & $\begin{array}{l}148.5 \\
178.7\end{array}$ & $\begin{array}{l}39.45 \\
39.48\end{array}$ & $\begin{array}{r}105.05 \\
89.31\end{array}$ & $\begin{array}{l}552 . \\
243 .\end{array}$ \\
\hline 258. & 2.8589 & $\begin{array}{l}14.239 \\
2.0585\end{array}$ & $\begin{array}{r}3.045 \\
.709\end{array}$ & $\begin{array}{l}.401 \\
.025\end{array}$ & $\begin{array}{l}17687.52 \\
24132.73\end{array}$ & $\begin{array}{l}17888.30 \\
25521.55\end{array}$ & $\begin{array}{l}148.9 \\
178.4\end{array}$ & $\begin{array}{l}39.59 \\
39.75\end{array}$ & $\begin{array}{r}106.94 \\
91.98\end{array}$ & $\begin{array}{l}542 . \\
242 .\end{array}$ \\
\hline 259. & 2.9307 & $\begin{array}{l}14.129 \\
2.1254\end{array}$ & $\begin{array}{r}2.880 \\
.687\end{array}$ & $\begin{array}{l}.392 \\
.026\end{array}$ & $\begin{array}{l}17781.53 \\
24117.53\end{array}$ & $\begin{array}{l}17988.95 \\
25496.44\end{array}$ & $\begin{array}{l}149.2 \\
178.2\end{array}$ & $\begin{array}{l}39.73 \\
40.02\end{array}$ & $\begin{array}{r}108.98 \\
94.87\end{array}$ & $\begin{array}{l}531 . \\
241 .\end{array}$ \\
\hline 260. & 3.0039 & $\begin{array}{l}14.017 \\
2.1949\end{array}$ & $\begin{array}{r}2.718 \\
.664\end{array}$ & $\begin{array}{l}.383 \\
.027\end{array}$ & $\begin{array}{l}17876.65 \\
24100.79\end{array}$ & $\begin{array}{l}18090.95 \\
25469.33\end{array}$ & $\begin{array}{l}149.6 \\
178.0\end{array}$ & $\begin{array}{l}39.88 \\
40.29\end{array}$ & $\begin{array}{r}111.19 \\
98.02\end{array}$ & $\begin{array}{l}520 \\
240\end{array}$ \\
\hline 251 . & 3.0783 & $\begin{array}{l}13.902 \\
2.2573\end{array}$ & $\begin{array}{r}2.559 \\
.642\end{array}$ & $\begin{array}{l}.373 \\
.028\end{array}$ & $\begin{array}{l}17972.96 \\
24082.42\end{array}$ & $\begin{array}{l}18194.39 \\
25440.10\end{array}$ & $\begin{array}{l}150.0 \\
177.7\end{array}$ & $\begin{array}{l}40.03 \\
40.58\end{array}$ & $\begin{array}{l}113.59 \\
101.45\end{array}$ & $\begin{array}{l}509 . \\
239 .\end{array}$ \\
\hline 262 . & 3.1542 & $\begin{array}{l}13.784 \\
2.3428\end{array}$ & $\begin{array}{r}2.403 \\
.519\end{array}$ & $\begin{array}{l}.364 \\
.029\end{array}$ & $\begin{array}{l}18070.53 \\
24062.30\end{array}$ & $\begin{array}{l}18299.35 \\
25408.51\end{array}$ & $\begin{array}{l}150.4 \\
177.5\end{array}$ & $\begin{array}{l}40.19 \\
40.87\end{array}$ & $\begin{array}{l}116.19 \\
105.21\end{array}$ & $\begin{array}{l}498 \\
238\end{array}$ \\
\hline 263. & 3.2314 & $\begin{array}{l}13.663 \\
2.4216\end{array}$ & $\begin{array}{r}2.250 \\
.594\end{array}$ & $\begin{array}{l}.354 \\
.030\end{array}$ & $\begin{array}{l}18169.45 \\
24040.29\end{array}$ & $\begin{array}{l}18405.96 \\
25374.70\end{array}$ & $\begin{array}{l}150.7 \\
177.2\end{array}$ & $\begin{array}{l}40.37 \\
41.18\end{array}$ & $\begin{array}{l}119.05 \\
109.35\end{array}$ & $\begin{array}{l}486 \\
237\end{array}$ \\
\hline 264 . & 3.3100 & $\begin{array}{l}13.538 \\
2.5039\end{array}$ & $\begin{array}{r}2.101 \\
.570\end{array}$ & $\begin{array}{l}.345 \\
.031\end{array}$ & $\begin{array}{l}18269.82 \\
24016.25\end{array}$ & $\begin{array}{l}18514.3 i \\
25338.18\end{array}$ & $\begin{array}{l}151.1 \\
177.0\end{array}$ & $\begin{array}{l}40.54 \\
41.49\end{array}$ & $\begin{array}{l}122.19 \\
113.92\end{array}$ & $\begin{array}{l}475 \\
236\end{array}$ \\
\hline 265. & 3.3900 & $\begin{array}{l}13.410 \\
2.5901\end{array}$ & $\begin{array}{r}1.954 \\
.545\end{array}$ & $\begin{array}{l}.336 \\
.033\end{array}$ & $\begin{array}{l}18371.76 \\
23990.01\end{array}$ & $\begin{array}{l}18624.56 \\
25298.84\end{array}$ & $\begin{array}{l}151.5 \\
176.7\end{array}$ & $\begin{array}{l}40.73 \\
41.81\end{array}$ & $\begin{array}{l}125.67 \\
119.01\end{array}$ & $\begin{array}{l}464 \\
235 .\end{array}$ \\
\hline$j$. & 3.4715 & $\begin{array}{l}13.277 \\
2.6806\end{array}$ & $\begin{array}{r}1.811 \\
.520\end{array}$ & $\begin{array}{l}.326 \\
.034\end{array}$ & $\begin{array}{l}18475.40 \\
23961.37\end{array}$ & $\begin{array}{l}18736.87 \\
25256.45\end{array}$ & $\begin{array}{l}151.9 \\
176.4\end{array}$ & $\begin{array}{l}40.93 \\
42.14\end{array}$ & $\begin{array}{l}129.54 \\
124.70\end{array}$ & $\begin{array}{l}452 . \\
234 .\end{array}$ \\
\hline$t$. & 3.5545 & $\begin{array}{l}13.140 \\
2.7756\end{array}$ & $\begin{array}{r}1.672 \\
.494\end{array}$ & $\begin{array}{l}.317 \\
.036\end{array}$ & $\begin{array}{l}18580.90 \\
23930.10\end{array}$ & $\begin{array}{l}18851.41 \\
25210.73\end{array}$ & $\begin{array}{l}152.3 \\
176.1\end{array}$ & $\begin{array}{l}41.14 \\
42.48\end{array}$ & $\begin{array}{l}133.88 \\
131.11\end{array}$ & $\begin{array}{l}440 \\
233\end{array}$ \\
\hline 3. & 3.6390 & $\begin{array}{l}12.998 \\
2.8758\end{array}$ & $\begin{array}{r}1.535 \\
.468\end{array}$ & $\begin{array}{l}.307 \\
.037\end{array}$ & $\begin{array}{l}18685.45 \\
23895.95\end{array}$ & $\begin{array}{l}1896 R .41 \\
25161.35\end{array}$ & $\begin{array}{l}152.7 \\
175.8\end{array}$ & $\begin{array}{l}41.37 \\
42.83\end{array}$ & $\begin{array}{l}138.80 \\
138.39\end{array}$ & $\begin{array}{l}423 \\
232\end{array}$ \\
\hline 3. & 3.7250 & $\begin{array}{l}12.851 \\
2.9816\end{array}$ & $\begin{array}{r}1.402 \\
.441\end{array}$ & $\begin{array}{l}.297 \\
.039\end{array}$ & $\begin{array}{l}19798.26 \\
23858.58\end{array}$ & $\begin{array}{l}19088.13 \\
25107.93\end{array}$ & $\begin{array}{l}153.2 \\
175.5\end{array}$ & $\begin{array}{l}41.61 \\
43.20\end{array}$ & $\begin{array}{l}144.42 \\
146.73\end{array}$ & $\begin{array}{l}416 . \\
231 .\end{array}$ \\
\hline 1. & 3.8126 & $\begin{array}{l}12.697 \\
3.0937\end{array}$ & $\begin{array}{r}1.272 \\
.413\end{array}$ & $\begin{array}{l}.288 \\
.041\end{array}$ & $\begin{array}{l}18910.61 \\
23817.64\end{array}$ & $\begin{array}{l}19210.87 \\
25050.01\end{array}$ & $\begin{array}{l}153.6 \\
175.2\end{array}$ & $\begin{array}{l}41.86 \\
43.57\end{array}$ & $\begin{array}{l}150.91 \\
156.39\end{array}$ & $\begin{array}{l}404 . \\
230 .\end{array}$ \\
\hline - & 3.9018 & $\begin{array}{l}12.537 \\
3.2130\end{array}$ & $\begin{array}{r}1.145 \\
.385\end{array}$ & $\begin{array}{l}.278 \\
.043\end{array}$ & $\begin{array}{l}19025.82 \\
23772.66\end{array}$ & $\begin{array}{l}19337.04 \\
24987.03\end{array}$ & $\begin{array}{l}154.0 \\
174.9\end{array}$ & $\begin{array}{l}42.13 \\
43.97\end{array}$ & $\begin{array}{l}158.51 \\
167.71\end{array}$ & $\begin{array}{l}392 . \\
229 .\end{array}$ \\
\hline - & 3.9926 & $\begin{array}{l}12.369 \\
3.3405\end{array}$ & $\begin{array}{r}1.022 \\
.356\end{array}$ & $\begin{array}{l}.268 \\
.045\end{array}$ & $\begin{array}{l}191.44 .30 \\
23723.08\end{array}$ & $\begin{array}{l}19467.10 \\
24919.29\end{array}$ & $\begin{array}{l}154.5 \\
174.5\end{array}$ & $\begin{array}{l}42.42 \\
44.38\end{array}$ & $\begin{array}{l}167.54 \\
181.16\end{array}$ & $\begin{array}{l}379 . \\
229 .\end{array}$ \\
\hline - & 4.0850 & $\begin{array}{l}12.191 \\
3.4774\end{array}$ & $\begin{array}{r}.902 \\
.326\end{array}$ & $\begin{array}{l}.258 \\
.047\end{array}$ & $\begin{array}{l}19266.59 \\
23668.17\end{array}$ & $\begin{array}{l}19601.67 \\
24842.90\end{array}$ & $\begin{array}{l}155.0 \\
174.1\end{array}$ & $\begin{array}{l}42.73 \\
44.81\end{array}$ & $\begin{array}{l}178.47 \\
197.44\end{array}$ & $\begin{array}{l}367 . \\
226 .\end{array}$ \\
\hline - & 4.1792 & $\begin{array}{l}12.002 \\
3.6255\end{array}$ & $\begin{array}{l}.786 \\
.296\end{array}$ & $\begin{array}{l}.248 \\
.049\end{array}$ & $\begin{array}{l}19393.37 \\
23607.02\end{array}$ & $\begin{array}{l}19741.56 \\
24759.75\end{array}$ & $\begin{array}{l}155.4 \\
173.7\end{array}$ & $\begin{array}{l}43.07 \\
45.26\end{array}$ & $\begin{array}{l}192.01 \\
217.56\end{array}$ & $\begin{array}{l}353 . \\
225 .\end{array}$ \\
\hline - & 4.2751 & $\begin{array}{l}11.801 \\
3.7869\end{array}$ & $\begin{array}{l}.673 \\
.264\end{array}$ & $\begin{array}{l}.238 \\
.052\end{array}$ & $\begin{array}{l}19525.57 \\
23538.38\end{array}$ & $\begin{array}{l}19887.84 \\
24667.29\end{array}$ & $\begin{array}{l}155.9 \\
173.3\end{array}$ & $\begin{array}{l}43.44 \\
45.74\end{array}$ & $\begin{array}{l}209.24 \\
243.07\end{array}$ & $\begin{array}{l}340 . \\
224 .\end{array}$ \\
\hline - & 4.3728 & $\begin{array}{l}11.582 \\
3.9648\end{array}$ & $\begin{array}{l}.564 \\
.232\end{array}$ & $\begin{array}{l}.227 \\
.055\end{array}$ & $\begin{array}{l}19664.49 \\
23460.55\end{array}$ & $\begin{array}{l}20042.02 \\
24563.45\end{array}$ & $\begin{array}{l}156.5 \\
172.8\end{array}$ & $\begin{array}{l}43.95 \\
46.25\end{array}$ & $\begin{array}{l}231.97 \\
276.56\end{array}$ & $\begin{array}{l}326 . \\
222 .\end{array}$ \\
\hline - & $4.47 ? 4$ & $\begin{array}{l}11.343 \\
4.1638\end{array}$ & $\begin{array}{l}.459 \\
.199\end{array}$ & $\begin{array}{l}.216 \\
.059\end{array}$ & $\begin{array}{l}19812.04 \\
23371.06\end{array}$ & $\begin{array}{l}20206.32 \\
24445.17\end{array}$ & $\begin{array}{l}157.0 \\
172.3\end{array}$ & $\begin{array}{l}44.30 \\
46.79\end{array}$ & $\begin{array}{l}263.38 \\
322.52\end{array}$ & $\begin{array}{l}312 . \\
221 .\end{array}$ \\
\hline
\end{tabular}


Table B-1. (Contl nued)

\begin{tabular}{|c|c|c|c|c|c|c|c|c|c|c|}
\hline \multirow{2}{*}{$\begin{array}{l}\text { Temp. } \\
\text { K } \\
278 .\end{array}$} & \multirow{2}{*}{$\begin{array}{l}\text { Pressure } \\
\text { MPa } \\
4.5739\end{array}$} & \multirow{2}{*}{$\begin{array}{l}\text { Denslty } \\
\text { mol/dm } \\
11.076 \\
4.3907\end{array}$} & \multirow{2}{*}{$\begin{array}{c}\text { I sotherm } \\
\text { Derivative } \\
\text { dm } 3 \text {-MPa/mol } \\
.358 \\
.164\end{array}$} & \multirow{2}{*}{$\begin{array}{c}\text { I sochore } \\
\text { Der ivative } \\
\text { MPa K } \\
.205 \\
.062\end{array}$} & \multirow{2}{*}{$\begin{array}{l}\text { Internal } \\
\text { Energy } \\
\text { J/mol } \\
19971.24 \\
23266.09\end{array}$} & \multirow{2}{*}{ 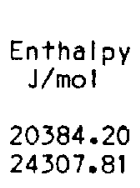 } & \multirow{2}{*}{$\begin{array}{l}\text { Entropy } \\
\mathrm{J} /(\text { mol } \cdot \mathrm{K}) \\
157.6 \\
171.8\end{array}$} & \multicolumn{2}{|c|}{$\left.{ }_{J}^{C_{V}} \quad C_{\text {mol }} \cdot k\right)^{C_{p}}$} & \multirow{2}{*}{$\begin{array}{c}\text { Veloclty } \\
\text { of sound } \\
\pi / s \\
297 . \\
219 .\end{array}$} \\
\hline & & & & & & & & $\begin{array}{l}44.83 \\
47.37\end{array}$ & $\begin{array}{l}309.74 \\
389.63\end{array}$ & \\
\hline 279. & 4.6774 & $\begin{array}{l}10.768 \\
4.6574\end{array}$ & $\begin{array}{l}.262 \\
.128\end{array}$ & $\begin{array}{l}.192 \\
.067\end{array}$ & $\begin{array}{l}20147.21 \\
23139.26\end{array}$ & $\begin{array}{l}20581.61 \\
24143.55\end{array}$ & $\begin{array}{l}158.3 \\
171.1\end{array}$ & $\begin{array}{l}45.44 \\
48.01\end{array}$ & $\begin{array}{l}385.16 \\
497.11\end{array}$ & $\begin{array}{l}282 . \\
218\end{array}$ \\
\hline 280 & 4.7831 & $\begin{array}{l}10.394 \\
4.9869\end{array}$ & $\begin{array}{l}.172 \\
.091\end{array}$ & $\begin{array}{l}.179 \\
.073\end{array}$ & $\begin{array}{l}20350.16 \\
22978.35\end{array}$ & $\begin{array}{l}20810.31 \\
23937.47\end{array}$ & $\begin{array}{l}159.1 \\
170.3\end{array}$ & $\begin{array}{l}46.19 \\
48.72\end{array}$ & $\begin{array}{l}529.36 \\
697.18\end{array}$ & $\begin{array}{l}265 \text {. } \\
216 \text {. }\end{array}$ \\
\hline 31. & 4.8910 & $\begin{array}{r}9.895 \\
5.4348\end{array}$ & $\begin{array}{l}.088 \\
.053\end{array}$ & $\begin{array}{l}.163 \\
.080\end{array}$ & $\begin{array}{l}20606.09 \\
22754.05\end{array}$ & $\begin{array}{l}21100.40 \\
23653.99\end{array}$ & $\begin{array}{l}160.1 \\
169.2\end{array}$ & $\begin{array}{l}47.20 \\
49.55\end{array}$ & $\begin{array}{r}911.93 \\
1197.30\end{array}$ & $\begin{array}{l}247 . \\
214 .\end{array}$ \\
\hline 32 & 5.0017 & $\begin{array}{r}8.956 \\
6.2349\end{array}$ & $\begin{array}{l}.016 \\
.015\end{array}$ & $\begin{array}{l}.139 \\
.093\end{array}$ & $\begin{array}{l}21049.80 \\
22347.15\end{array}$ & $\begin{array}{l}21608.28 \\
23149.35\end{array}$ & $\begin{array}{l}161.9 \\
167.3\end{array}$ & $\begin{array}{l}48.99 \\
50.55\end{array}$ & $\begin{array}{l}4431.04 \\
4272.17\end{array}$ & $\begin{array}{l}224 \\
212\end{array}$ \\
\hline
\end{tabular}


Table B-2. Thermodynamic Properties of Ethylene

.05 megapascal Isobar

\begin{tabular}{|c|c|c|c|c|c|c|c|c|c|}
\hline $\begin{array}{c}\text { Temp. } \\
k\end{array}$ & $\begin{array}{l}\text { Density } \\
\mathrm{mol}^{3} \mathrm{dm}^{3}\end{array}$ & $\begin{array}{l}\text { Isotherm } \\
\text { Der ivative } \\
\text { dm X-MPa/mol }\end{array}$ & $\begin{array}{c}\text { Isochore } \\
\text { Derivative } \\
\text { :Pa/K }\end{array}$ & $\begin{array}{l}\text { Internal } \\
\text { Energy } \\
\mathrm{J} / \text { mol }\end{array}$ & $\begin{array}{c}\text { Enthalpy } \\
\text { J/mol }\end{array}$ & $\begin{array}{l}\text { Entropy } \\
J /(\text { mol-k) }\end{array}$ & $\begin{array}{l}C_{V} \\
J / 6 m\end{array}$ & $c_{p}$ & $\begin{array}{l}\text { Velocity } \\
\text { of Sound } \\
\mathrm{m} / \mathrm{s}\end{array}$ \\
\hline $\begin{array}{l}103.993 \\
110.0 \\
120.0 \\
130.0 \\
140.0 \\
150.0 \\
* 158.297\end{array}$ & $\begin{array}{l}23.390 \\
23.052 \\
22.573 \\
22.122 \\
21.669 \\
21.203 \\
20.802\end{array}$ & $\begin{array}{l}45.998 \\
50.235 \\
49.309 \\
45.249 \\
40.384 \\
35.520 \\
31.719\end{array}$ & $\begin{array}{l}2.908 \\
2.587 \\
2.256 \\
2.032 \\
1.850 \\
1.687 \\
1.559\end{array}$ & $\begin{array}{r}6614.60 \\
7044.44 \\
7729.74 \\
3402.41 \\
9070.17 \\
9737.71 \\
10293.90\end{array}$ & $\begin{array}{r}6616.74 \\
7046.61 \\
7731.96 \\
8404.67 \\
9072.48 \\
9740.07 \\
10295.30\end{array}$ & $\begin{array}{r}81.4 \\
88.4 \\
94.4 \\
99.8 \\
104.7 \\
109.3 \\
112.9\end{array}$ & $\begin{array}{l}39.49 \\
42.19 \\
43.41 \\
42.71 \\
41.43 \\
40.14 \\
39.21\end{array}$ & $\begin{array}{l}74.43 \\
69.76 \\
67.72 \\
66.94 \\
66.70 \\
66.87 \\
67.23\end{array}$ & $\begin{array}{l}1758 . \\
1721 . \\
1656 . \\
1590 . \\
1522 . \\
1452 . \\
1392 .\end{array}$ \\
\hline $\begin{array}{l}158.297 \\
160.0 \\
170.0 \\
180.0 \\
190.0 \\
200.0 \\
210.0 \\
220.0 \\
230.0 \\
240.0 \\
245.0 \\
250.0 \\
256.0 \\
258.0 \\
260.0 \\
262.0 \\
264.0 \\
265.0 \\
268.0 \\
270.0 \\
275.0 \\
280.0 \\
285.0 \\
290.0 \\
295.0 \\
300.0 \\
305.0 \\
310.0 \\
320.0 \\
330.0 \\
340.0 \\
350.0 \\
360.0 \\
370.0 \\
380.0 \\
390.0 \\
400.0 \\
425.0 \\
450.0\end{array}$ & $\begin{array}{l}.038789 \\
.038347 \\
.035953 \\
.033859 \\
.032007 \\
.030355 \\
.028871 \\
.027528 \\
.026308 \\
.025193 \\
.024670 \\
.024170 \\
.023595 \\
.023410 \\
.023227 \\
.023048 \\
.022871 \\
.022697 \\
.022526 \\
.022357 \\
.021946 \\
.021550 \\
.021168 \\
.020800 \\
.020444 \\
.020100 \\
.019768 \\
.019447 \\
.018834 \\
.019260 \\
.017719 \\
.017210 \\
.016730 \\
.016275 \\
.015845 \\
.015437 \\
.015050 \\
.014161 \\
.013372 \\
.050 \\
.00\end{array}$ & $\begin{array}{l}1.262 \\
1.277 \\
1.368 \\
1.457 \\
1.545 \\
1.631 \\
1.718 \\
1.803 \\
1.889 \\
1.974 \\
2.016 \\
2.059 \\
2.110 \\
2.127 \\
2.144 \\
2.160 \\
2.177 \\
2.194 \\
2.211 \\
2.228 \\
2.270 \\
2.312 \\
2.355 \\
2.397 \\
2.439 \\
2.481 \\
2.523 \\
2.565 \\
2.649 \\
2.733 \\
2.817 \\
2.900 \\
2.984 \\
3.068 \\
3.152 \\
3.235 \\
3.319 \\
3.528 \\
3.737\end{array}$ & $\begin{array}{l}.000332 \\
.000328 \\
.000305 \\
.000286 \\
.000270 \\
.000255 \\
.000242 \\
.000231 \\
.000220 \\
.000211 \\
.000206 \\
.000202 \\
.000197 \\
.000196 \\
.000194 \\
.000192 \\
.000191 \\
.000189 \\
.000188 \\
.000187 \\
.000183 \\
.000180 \\
.000177 \\
.000174 \\
.000171 \\
.000168 \\
.000165 \\
.000162 \\
.000157 \\
.000152 \\
.000148 \\
.000143 \\
.000139 \\
.000136 \\
.000132 \\
.000129 \\
.000125 \\
.000118 \\
.000111\end{array}$ & $\begin{array}{l}22985.93 \\
23031.63 \\
23299.50 \\
23567.72 \\
23837.72 \\
24110.70 \\
24387.68 \\
24669.55 \\
24957.12 \\
25251.09 \\
25400.69 \\
25552.12 \\
25736.37 \\
25798.41 \\
25860.78 \\
25923.47 \\
25986.49 \\
26049.84 \\
26113.53 \\
26177.56 \\
26339.14 \\
26502.91 \\
26669.92 \\
26837.21 \\
27007.81 \\
27180.75 \\
27356.10 \\
27533.83 \\
27896.62 \\
28269.27 \\
28651.90 \\
29044.55 \\
29447.27 \\
29860.05 \\
30282.94 \\
30715.51 \\
31158.28 \\
32307.75 \\
33517.26\end{array}$ & $\begin{array}{l}24274.96 \\
24335.51 \\
24690.19 \\
25044.41 \\
25399.86 \\
25757.85 \\
26119.54 \\
26485.87 \\
26857.71 \\
27235.81 \\
27427.42 \\
27620.84 \\
27855.43 \\
27934.26 \\
28013.40 \\
28092.85 \\
28172.64 \\
29252.77 \\
29333.22 \\
28411.01 \\
28617.48 \\
28823.12 \\
29030.98 \\
29241.11 \\
29453.54 \\
29668.31 \\
29885.45 \\
30104.99 \\
30551.34 \\
31007.53 \\
31473.67 \\
31949.81 \\
32435.98 \\
32932.20 \\
33438.41 \\
33954.58 \\
34480.64 \\
35838.52 \\
37256.37\end{array}$ & $\begin{array}{l}201.2 \\
201.6 \\
203.8 \\
205.8 \\
207.7 \\
209.6 \\
211.3 \\
213.0 \\
214.7 \\
216.3 \\
217.1 \\
217.9 \\
218.8 \\
219.1 \\
219.4 \\
219.7 \\
220.0 \\
220.3 \\
220.6 \\
220.9 \\
221.7 \\
222.4 \\
223.1 \\
223.9 \\
224.6 \\
225.3 \\
226.0 \\
226.7 \\
228.2 \\
229.6 \\
231.0 \\
232.3 \\
233.7 \\
235.1 \\
236.4 \\
237.8 \\
239.1 \\
242.4 \\
245.6\end{array}$ & $\begin{array}{l}26.40 \\
26.39 \\
26.45 \\
26.63 \\
26.92 \\
27.31 \\
27.78 \\
28.34 \\
28.96 \\
29.65 \\
30.01 \\
30.39 \\
30.87 \\
31.03 \\
31.19 \\
31.36 \\
31.52 \\
31.69 \\
31.86 \\
32.04 \\
32.47 \\
32.92 \\
33.37 \\
33.83 \\
34.30 \\
34.78 \\
35.26 \\
35.75 \\
36.73 \\
37.72 \\
38.73 \\
39.74 \\
40.74 \\
41.75 \\
42.75 \\
43.75 \\
44.74 \\
47.17 \\
49.55\end{array}$ & $\begin{array}{l}35.60 \\
35.56 \\
35.41 \\
35.46 \\
35.65 \\
35.97 \\
36.39 \\
36.90 \\
37.49 \\
38.15 \\
38.50 \\
38.87 \\
39.33 \\
39.49 \\
39.65 \\
39.81 \\
39.98 \\
40.14 \\
40.31 \\
40.48 \\
40.91 \\
41.35 \\
41.80 \\
42.25 \\
42.72 \\
43.19 \\
43.67 \\
44.15 \\
45.13 \\
46.11 \\
47.11 \\
48.12 \\
49.12 \\
50.12 \\
51.12 \\
52.11 \\
53.10 \\
55.52 \\
57.90\end{array}$ & 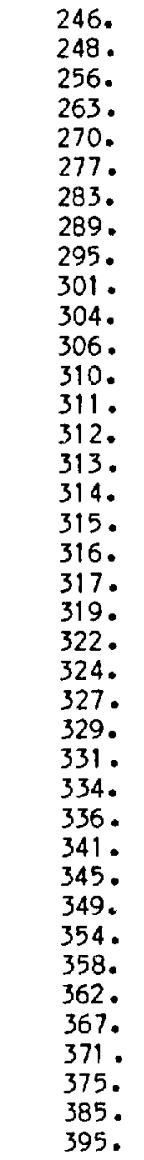 \\
\hline
\end{tabular}

* Saturated state 
Table B-2. (Continued)

.10 megapascal Isobar

\begin{tabular}{|c|c|c|c|c|c|c|c|c|c|}
\hline $\begin{array}{c}\text { Temp. } \\
k\end{array}$ & $\begin{array}{l}\text { Density } \\
\text { mo! } / \mathrm{dm}^{3}\end{array}$ & $\begin{array}{l}\text { I sotherm } \\
\text { Derivative } \\
\text { dm } 3 \text {-MPa/mol }\end{array}$ & $\begin{array}{c}\text { I sochore } \\
\text { Der Ivat Ive } \\
\mathrm{Ma} / \mathrm{K}\end{array}$ & $\begin{array}{l}\text { Internal } \\
\text { Energy } \\
\mathrm{J} / \text { mol }\end{array}$ & $\begin{array}{l}\text { Enthalpy } \\
\text { J/mol }\end{array}$ & $\begin{array}{l}\text { Entropy } \\
J /(m o l \cdot k)\end{array}$ & $\mathrm{J} / \mathrm{(m}$ & $c_{p}$ & $\begin{array}{c}\text { velocity } \\
\text { of sound } \\
\mathrm{m} / \mathrm{s}\end{array}$ \\
\hline $\begin{array}{c}* 104.000 \\
110.0 \\
120.0 \\
130.0 \\
140.0 \\
150.0 \\
160.0 \\
* 169.186\end{array}$ & $\begin{array}{l}23.391 \\
23.053 \\
22.574 \\
22.123 \\
21.670 \\
21.204 \\
20.720 \\
20.256\end{array}$ & $\begin{array}{l}45.989 \\
50.232 \\
49.318 \\
45.264 \\
40.403 \\
35.540 \\
30.994 \\
27.184\end{array}$ & $\begin{array}{l}2.907 \\
2.587 \\
2.256 \\
2.032 \\
1.350 \\
1.687 \\
1.533 \\
1.399\end{array}$ & $\begin{array}{r}6614.52 \\
7043.90 \\
7729.21 \\
8401.81 \\
9069.49 \\
9736.92 \\
10407.53 \\
11028.38\end{array}$ & $\begin{array}{r}6518.80 \\
7048.24 \\
7733.64 \\
8406.33 \\
9074.10 \\
9741.63 \\
10412.36 \\
11033.31\end{array}$ & $\begin{array}{r}84.4 \\
88.4 \\
94.4 \\
99.8 \\
104.7 \\
109.3 \\
113.6 \\
117.4\end{array}$ & $\begin{array}{l}39.51 \\
42.20 \\
43.42 \\
42.71 \\
41.43 \\
40.15 \\
39.04 \\
38.24\end{array}$ & $\begin{array}{l}74.45 \\
69.77 \\
67.72 \\
66.93 \\
66.70 \\
66.97 \\
67.32 \\
67.90\end{array}$ & $\begin{array}{l}1758 . \\
1721 . \\
1656 . \\
1590^{\circ} \\
1523 . \\
1453 . \\
1380^{\circ} \\
1312 .\end{array}$ \\
\hline $\begin{array}{l}* 169.186 \\
170.0 \\
180.0 \\
190.0 \\
200.0 \\
210.0 \\
220.0 \\
230.0 \\
240.0 \\
245.0 \\
250.0 \\
256.0 \\
258.0 \\
260.0 \\
262.0 \\
254.0 \\
266.0 \\
268.0 \\
270.0 \\
275.0 \\
280.0 \\
285.0 \\
290.0 \\
295.0 \\
300.0 \\
305.0 \\
310.0 \\
320.0 \\
330.0 \\
340.0 \\
350.0 \\
360.0 \\
370.0 \\
380.0 \\
390.0 \\
400.0 \\
425.0 \\
450.0\end{array}$ & $\begin{array}{l}.073548 \\
.073154 \\
.068674 \\
.064764 \\
.051308 \\
.058226 \\
.055454 \\
.052945 \\
.050662 \\
.049595 \\
.048573 \\
.047402 \\
.047025 \\
.046654 \\
.046288 \\
.045929 \\
.045575 \\
.045227 \\
.044884 \\
.044050 \\
.043246 \\
.042472 \\
.041726 \\
.041005 \\
.040310 \\
.039638 \\
.038989 \\
.037752 \\
.036593 \\
.035503 \\
.034477 \\
.033509 \\
.032595 \\
.031729 \\
.030909 \\
.030130 \\
.028345 \\
.026761\end{array}$ & $\begin{array}{l}1.312 \\
1.320 \\
1.415 \\
1.508 \\
1.599 \\
1.689 \\
1.777 \\
1.865 \\
1.952 \\
1.996 \\
2.039 \\
2.091 \\
2.108 \\
2.125 \\
2.142 \\
2.160 \\
2.177 \\
2.194 \\
2.211 \\
2.254 \\
2.297 \\
2.339 \\
2.382 \\
2.425 \\
2.467 \\
2.510 \\
2.552 \\
2.637 \\
2.722 \\
2.806 \\
2.891 \\
2.975 \\
3.060 \\
3.144 \\
3.228 \\
3.312 \\
3.522 \\
3.732\end{array}$ & $\begin{array}{l}.000640 \\
.000636 \\
.000591 \\
.000553 \\
.000521 \\
.000493 \\
.000468 \\
.000446 \\
.000426 \\
.000417 \\
.000408 \\
.000398 \\
.000394 \\
.000391 \\
.000388 \\
.000385 \\
.000382 \\
.000379 \\
.000376 \\
.000369 \\
.000362 \\
.000356 \\
.000349 \\
.000343 \\
.000337 \\
.000332 \\
.000326 \\
.000316 \\
.000306 \\
.000297 \\
.000288 \\
.000280 \\
.000272 \\
.000265 \\
.000258 \\
.000251 \\
.000236 \\
.000223\end{array}$ & $\begin{array}{l}23221.29 \\
23243.94 \\
23521.24 \\
23798.09 \\
24075.35 \\
24357.47 \\
24642.64 \\
24932.88 \\
25229.04 \\
25379.58 \\
25531.88 \\
25717.07 \\
25779.41 \\
25842.06 \\
25905.03 \\
25968.31 \\
26031.93 \\
26095.87 \\
26160.14 \\
26322.29 \\
26486.60 \\
26653.11 \\
26821.86 \\
26992.90 \\
27166.26 \\
27341.97 \\
27520.07 \\
27883.52 \\
28256.78 \\
28639.94 \\
29033.10 \\
29436.27 \\
29849.46 \\
30272.65 \\
30705.78 \\
31148.79 \\
32299.03 \\
33509.22\end{array}$ & $\begin{array}{l}24580.95 \\
24610.92 \\
24977.38 \\
25342.17 \\
25707.46 \\
26074.93 \\
26445.94 \\
26821.62 \\
27202.92 \\
27395.94 \\
27590.65 \\
27826.67 \\
27905.94 \\
27985.51 \\
28065.39 \\
28145.59 \\
28226.11 \\
28306.94 \\
28388.11 \\
28592.45 \\
28798.95 \\
29007.60 \\
29218.46 \\
29431.59 \\
29647.02 \\
29864.79 \\
30084.91 \\
30532.36 \\
30989.55 \\
31456.59 \\
31933.57 \\
32420.52 \\
32917.45 \\
33424.33 \\
33941.13 \\
34467.77 \\
35826.97 \\
37245.98\end{array}$ & $\begin{array}{l}197.5 \\
197.7 \\
199.8 \\
201.7 \\
203.6 \\
205.4 \\
207.1 \\
208.8 \\
210.4 \\
211.2 \\
212.0 \\
212.9 \\
213.3 \\
213.6 \\
213.9 \\
214.2 \\
214.5 \\
214.8 \\
215.1 \\
215.8 \\
216.6 \\
217.3 \\
218.0 \\
218.8 \\
219.5 \\
220.2 \\
220.9 \\
222.4 \\
223.8 \\
225.2 \\
226.5 \\
227.9 \\
229.3 \\
230.6 \\
232.0 \\
233.3 \\
236.6 \\
239.8\end{array}$ & $\begin{array}{l}27.11 \\
27.10 \\
27.11 \\
27.28 \\
27.58 \\
28.00 \\
28.50 \\
29.09 \\
29.75 \\
30.10 \\
30.47 \\
30.94 \\
31.10 \\
31.26 \\
31.42 \\
31.58 \\
31.75 \\
31.92 \\
32.09 \\
32.52 \\
32.96 \\
33.41 \\
33.87 \\
34.34 \\
34.81 \\
35.29 \\
35.77 \\
36.75 \\
37.74 \\
38.74 \\
39.75 \\
40.76 \\
41.76 \\
42.76 \\
43.76 \\
44.74 \\
47.18 \\
49.55\end{array}$ & $\begin{array}{l}36.86 \\
36.82 \\
36.52 \\
36.47 \\
36.61 \\
36.90 \\
37.32 \\
37.83 \\
38.44 \\
38.77 \\
39.12 \\
39.56 \\
39.71 \\
39.86 \\
40.02 \\
40.18 \\
40.34 \\
40.50 \\
40.66 \\
41.08 \\
41.51 \\
41.95 \\
42.40 \\
42.85 \\
43.32 \\
43.79 \\
44.26 \\
45.23 \\
46.21 \\
47.20 \\
48.20 \\
49.19 \\
50.19 \\
51.18 \\
52.17 \\
53.15 \\
55.57 \\
57.94\end{array}$ & $\begin{array}{l}252 . \\
253 . \\
26 ! \\
268 . \\
275 . \\
292 . \\
288 . \\
294 . \\
300 . \\
303 . \\
305 . \\
309 . \\
310 . \\
311 . \\
312 . \\
313 . \\
314 . \\
315 . \\
316 . \\
319 . \\
321 . \\
324 . \\
325 . \\
329 . \\
331 . \\
333 . \\
335 . \\
340 . \\
345 . \\
349 . \\
353 . \\
358 . \\
362 . \\
366 . \\
370 . \\
375 . \\
385 . \\
394 .\end{array}$ \\
\hline
\end{tabular}

\footnotetext{
- Saturated state
} 
Table B-2, (Continued)

.101325 megapascal Isobar

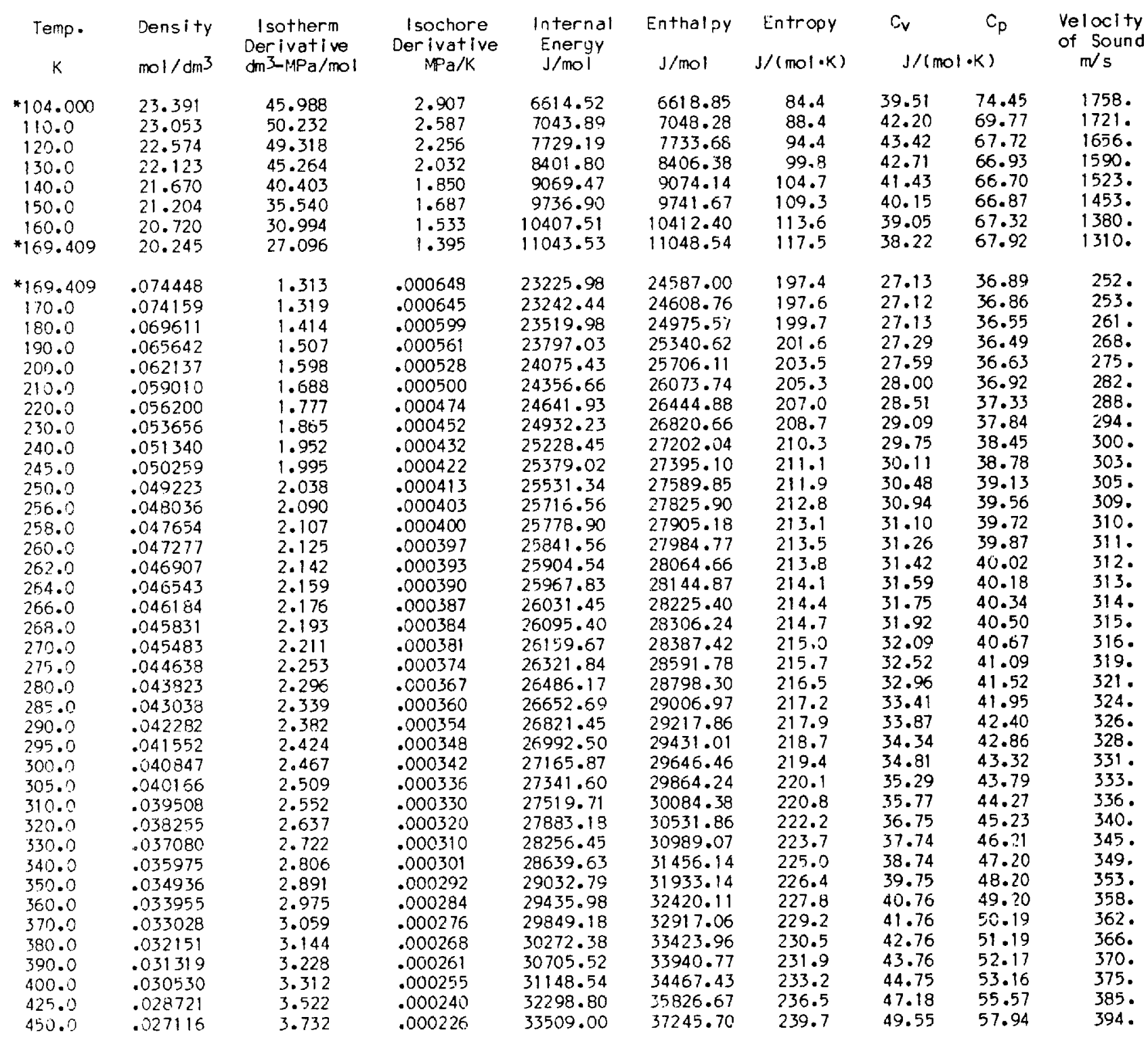

* Saturated state 